آليات التأويل النحوي

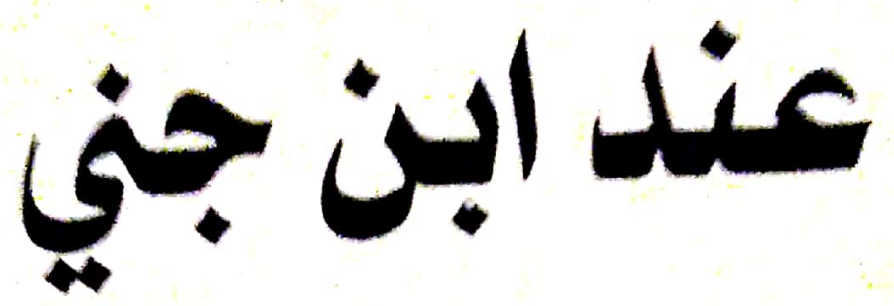

\author{
دكتور

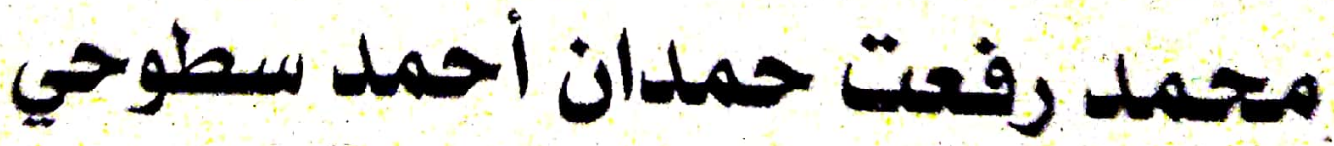 \\ الأستاذ الساعد في جامعة الأزهر
}




\section{آليات التأويل النحوي \\ عند ابن جني التئ}

/ / محمد رفعت حمدان أحمد سطوحي جني

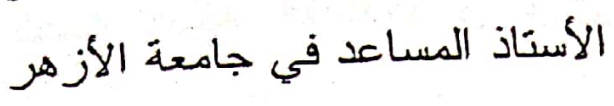

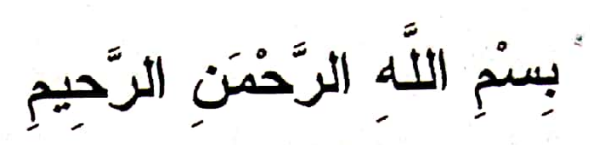

\section{مقدمة}

الحمد له رب العالمين و الصـلاة و السلام على أشرف المرسـلين ســيدنا

$$
\text { محمد و على آله و أصحابه أجمعين.... }
$$

فان النحو كعلم لم يبدأ منكاملأ، وهذا شأن العلوم ؛ فكان عبارة عن جزئيات ظهرت بسبب اللحن الذى عم مناطق العرب، وهذه الجزئيات كانت

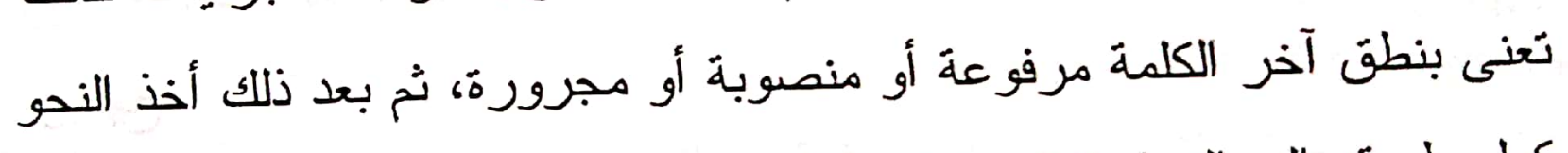
كعلم طريقه إلى الدراسة المنهجية من عبد الله ابن اسحاق وتلاميذه، وبدأ الخليل

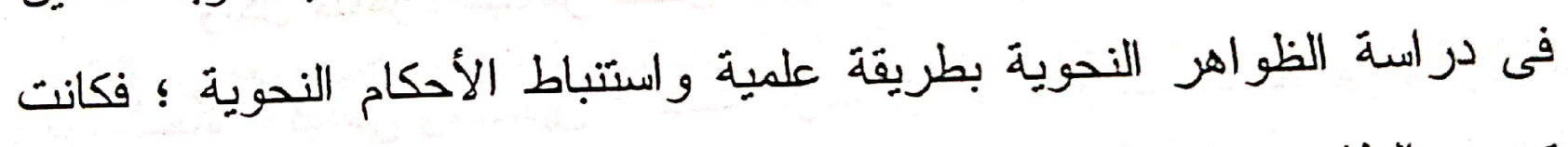
تكرس الظاهرة من ناحية وجودها و عدمها عند العرب، ومدى الستحكامها فى

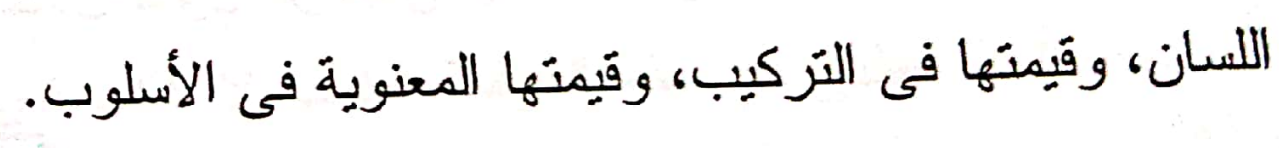
ولم تكن ظاهرة التأويل قُ عرفت فى النحو ؛ لأنها ارثبطت بالنص الأى بخرج عن القاعدة، ومما يدل على ذللك أن المساجلات التى دارت بين ابن أبى أنحات النحوى والفرزدق الشاعر لم يقع فيه تأويل من النحاة المعاصرين للشاعز ، و إنما الذى وقَع منهم كان تخطئة للانشر. 
وعرف النحو و النحاة ظاهزة التأويل بعد أن استتبطوا القاعدة من الكلام

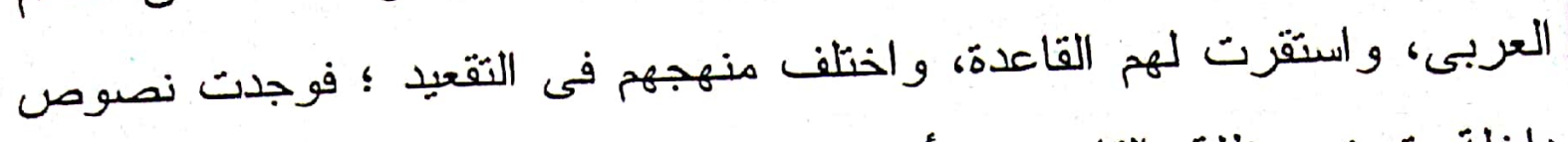

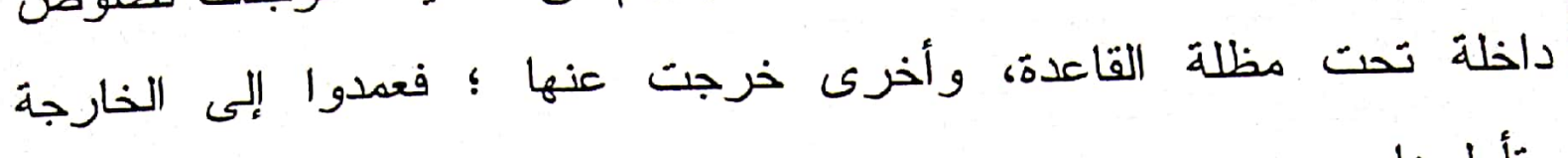
وتأولو ها.

فالنحاة مارسوا التأويل لكن لم يجعلوه فكرة مرتبطة بمنهج علمى محكم

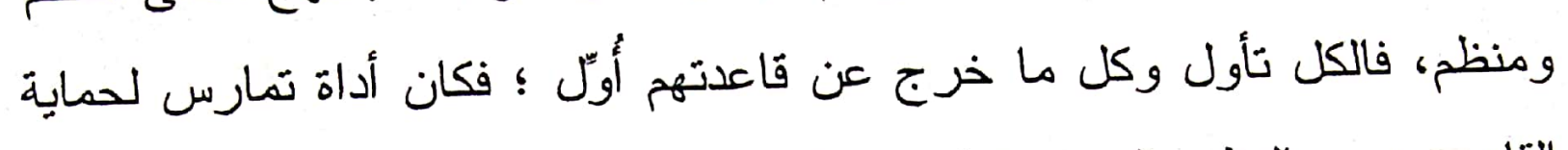
القاعدة دون النظر إلى قيمتها وصلاحيتها للنص وعدم صلاحيتها، و انحصر

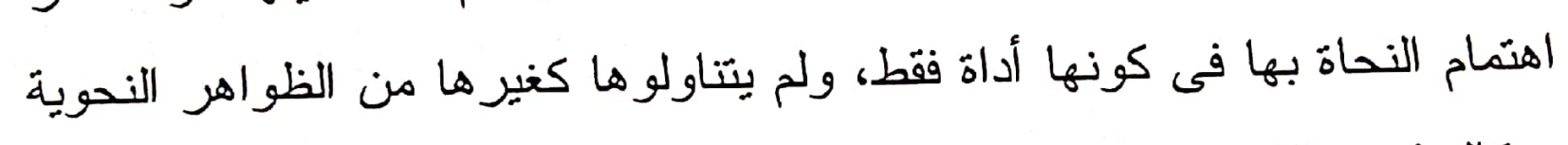
- كالحذف و الذكر و الفصل و التقديم.... إلخ. و على أية حال فالتأويل عرف طريقه إلى النحو، وكان ابن جنى رائد

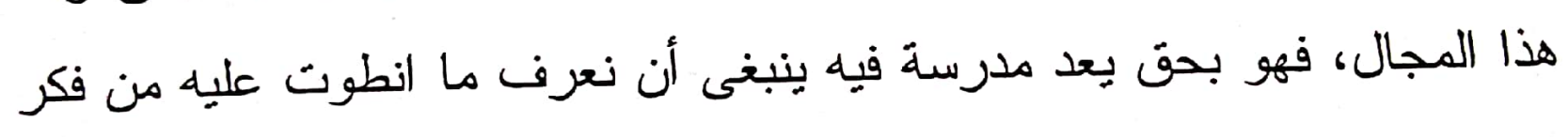
ومنهج.

ولكل ظاهرة مظاهر تُحمل عليها، وقد ذُكرت مظاهر التأويل عند كثير من النحاة - قدامى ومحدثين - لذلك آثرت أن أدرس و استتبط مظاهر و آليات لم تذكر من قبل من خلص تتاول ابن جنى لهذه الظاهرة ؛ فعنونته: " آليات التأويل

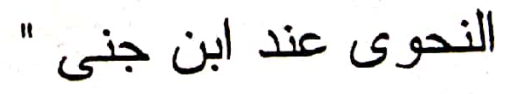

ويرجع السبب من البحث فى هذا الموضوع: أن ابن جنى يعد علماً بارزاً، ورائداً فريداً فى هذا الفن، ومعالم الشئ ومعرفته تؤخذ من البارزين

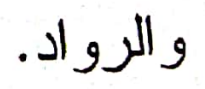




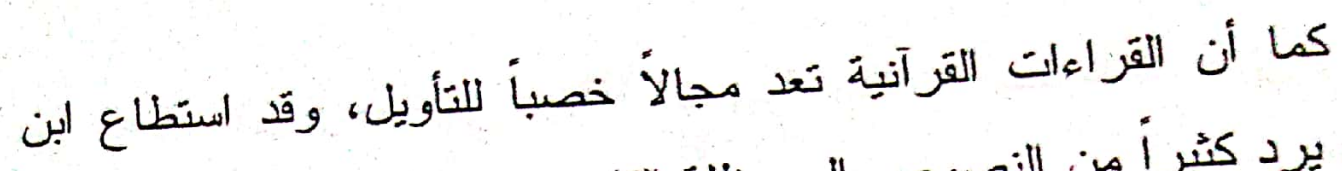
جنى أن يرد كثير أ من النصوص إلى مظلة القاعدة، وهذا بخلاف غير القراءات

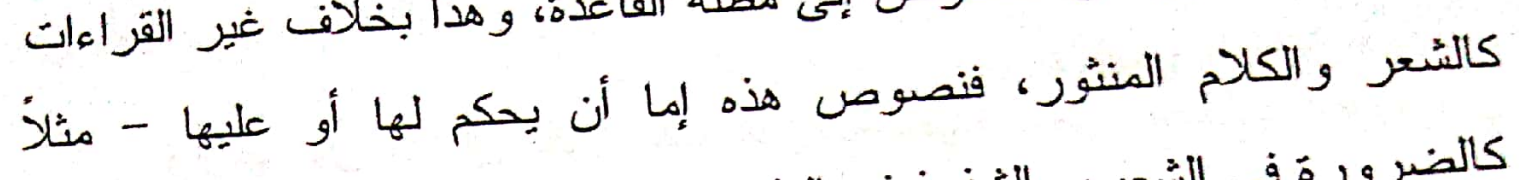

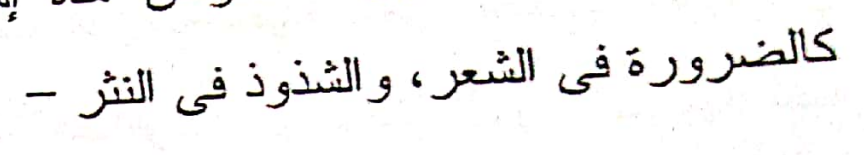

كما أن من بطالع مؤلفات ابن جنى ويقف مع النص المتأول برهة بِيد أن هذا العالم قد وظف كل قو انين العقل فى إرجاع النص إلى الدائرة اللغوية. ومن أسباب الاراسةً أن هناك مظاهر لم ينص عليها النحاة، ومارسها ابن جنى فى تأويلاتهة، و هذا هو أقوى أسباب الدراسة. وقد قدمت هذا البحث بمقدة - بعد حمد اله والصلاة ُعلى نبيه

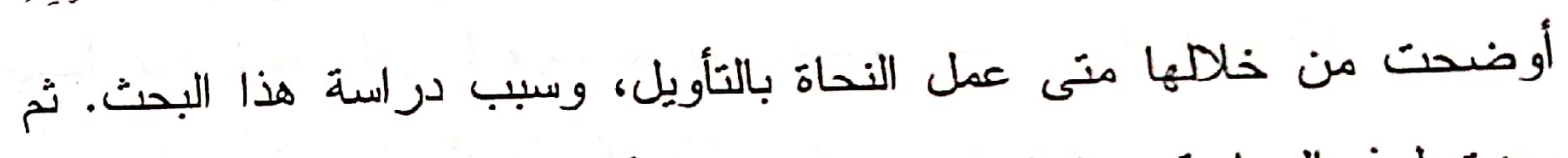

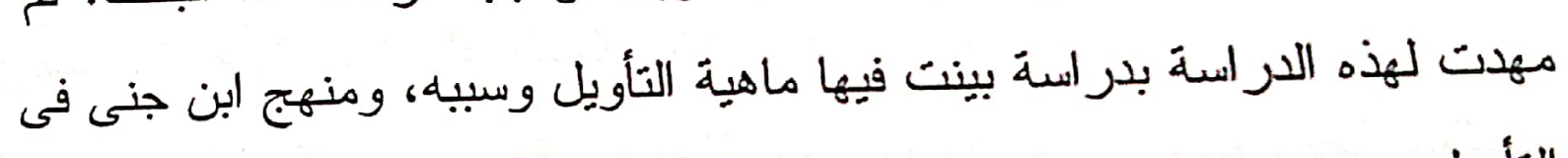
التَأويل.

ودرست الآليات مرتبهَ ومرقمة، ودللت عليها بنماذج، ثم بينت عيوب التأويل ومزاياه، ثُ ذيلت هذه الدراسة بخانمة احتوث على بعض النتائج و التوصيات، و أعددت فهرسأ لمحتوى البحث حتى يسهل الرجوع إلى جزئياته.

وكانت خطتى فى هذه الدراسة الكيف لا الكم، فقمت بدراسة القضية النحوية التى تأولها ابن جنى، واستبطبت لها اسمأ للَّية يتفق مع ما ذكره ابن جنى فى قَضاياه التأويليةَ، ووضعت ذللك الاسم عنواناً لها، ثم ذكرث نماذج للآية على نبيلِ المثال لا الحصر، وما ذكر من نماذج قمت بتحليله تحليلاً أوضحت فيه ما لابن جنى وما عليه، وبينت من خلال التحليل صنيع ابن جنى 
مع النص حتى يرجعه إلى المظلة التقعيدية، وبينت الملحوظات - إن وجدت وأرجو من اله أن تكون هذه الدراسة مفيدة منمرة لطلادب العلم، وأن

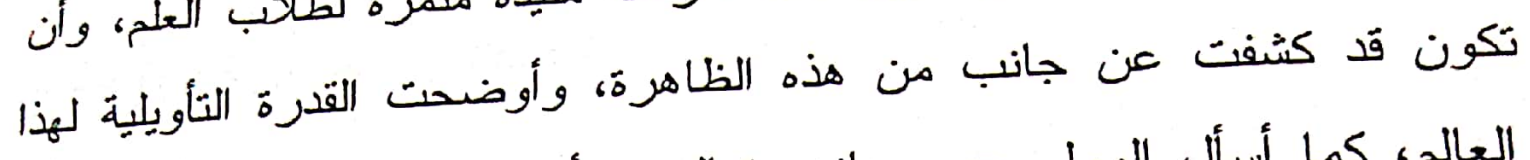

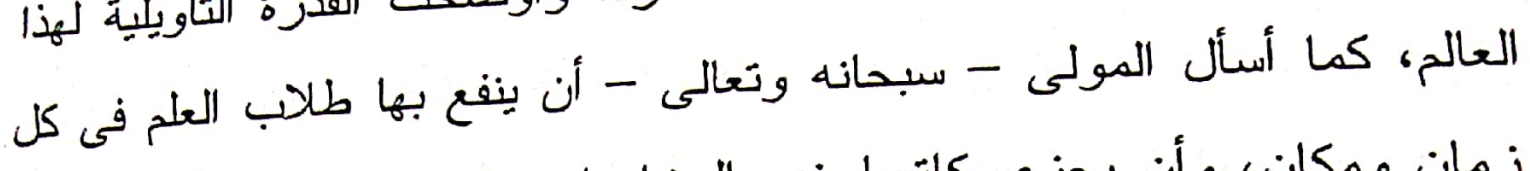
زمان ومكان، وأن يجزى كاتبها خير الجزاء إنه على كل شئ قدير، وبالإجابة جدير

.. و آخر دعو اهم أن الحمد لله رب العالمين..

وصل اللهم على سيدنا محمد وعلى آله وصحبه وسلم.. 


\section{التمهيد}

ماهية التأويل ومظاهره:

هَبل أن نوضتح معنى التأويل ومظاهره يجب علينا أن نشير إلـى مــا

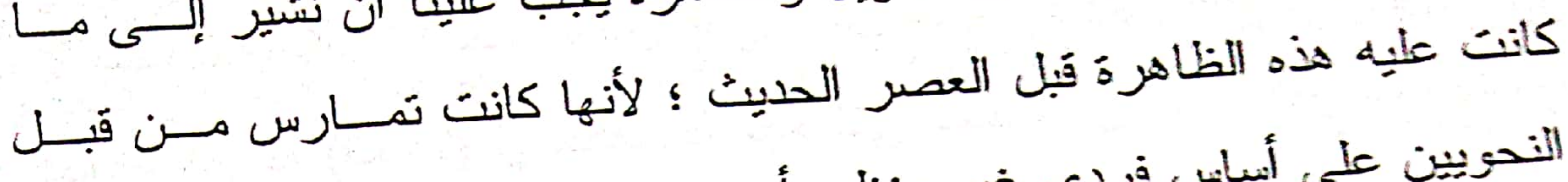
النحويين على أساس فردي غير منظم، أو مدروس.

فالنحاة مارسوه في مؤلفاتهم، ودافعوا به عن قو اعدهم وأصوالهم لكنهم

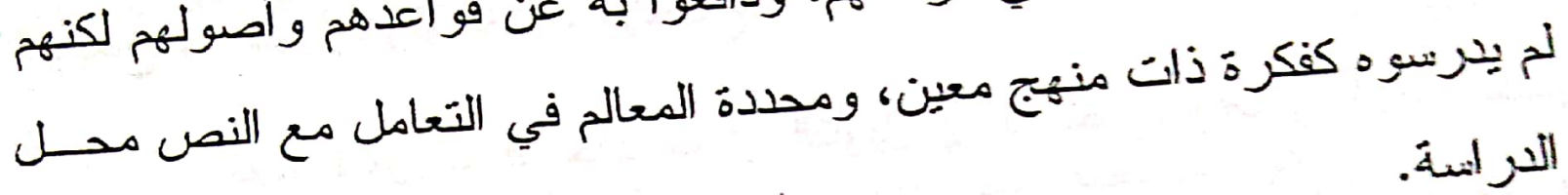

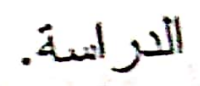

وأول تعريف له نقلته المصادر هو ما ذكره السيوطي نقالً عـن أبسـي

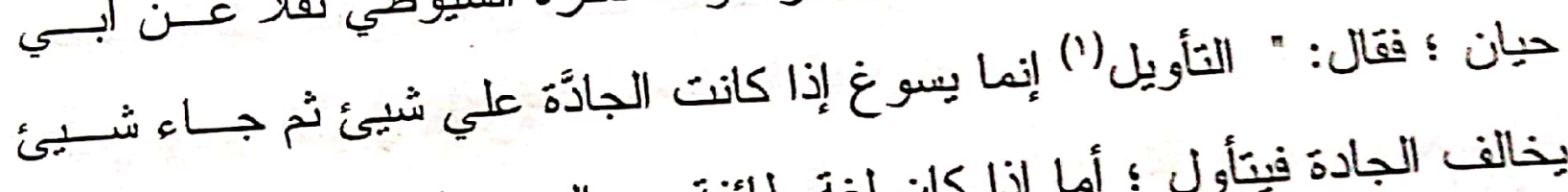

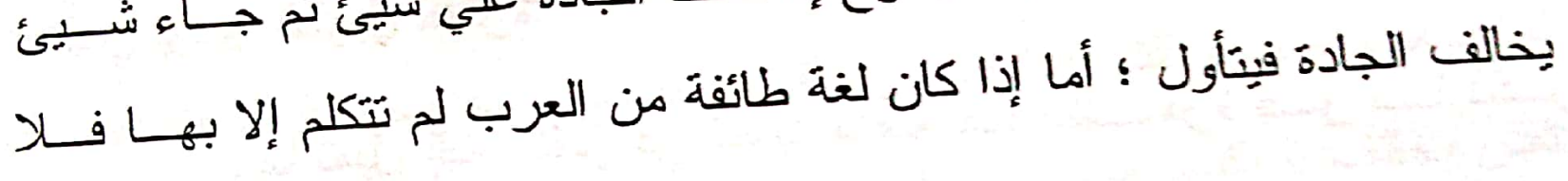

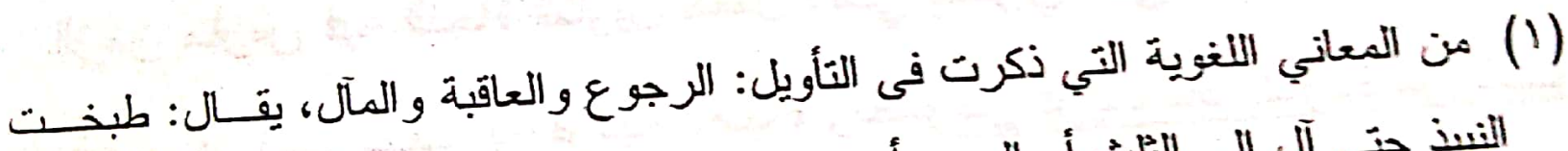

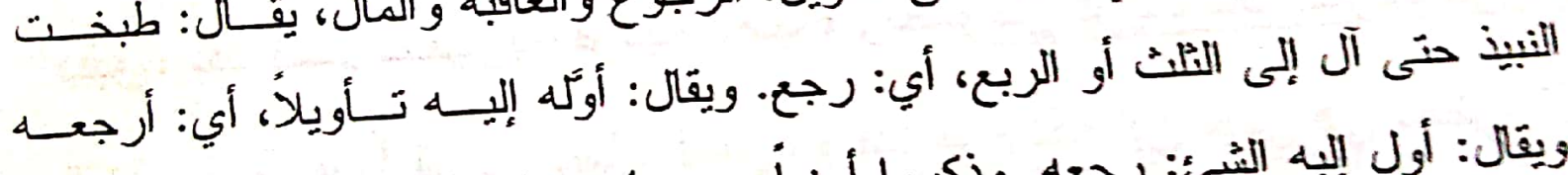

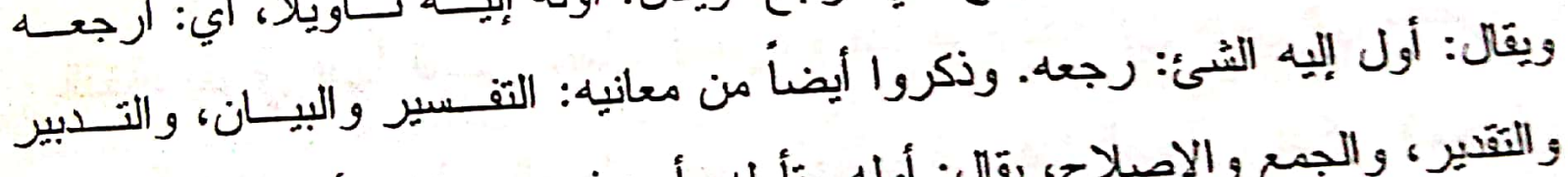

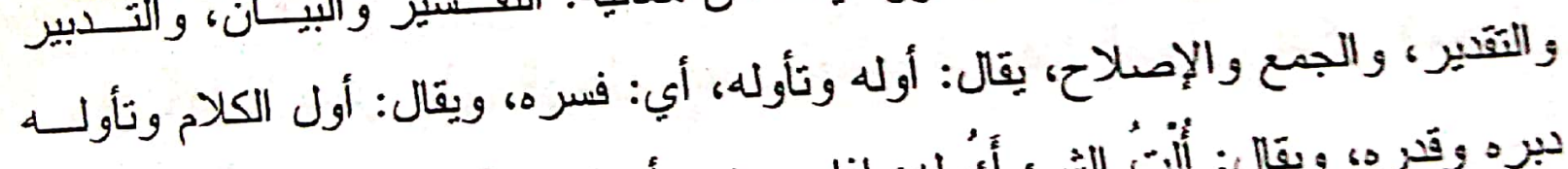

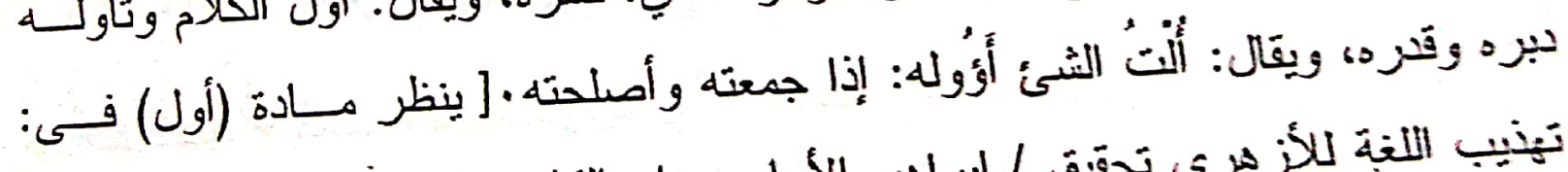

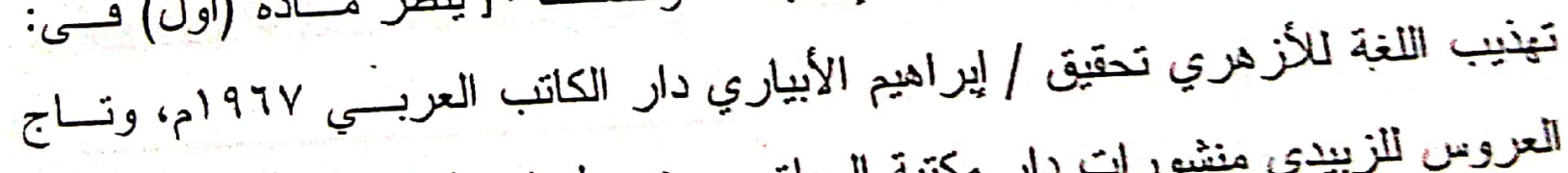

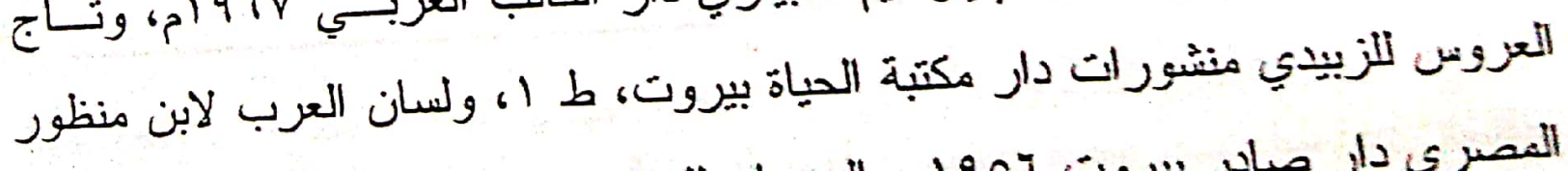

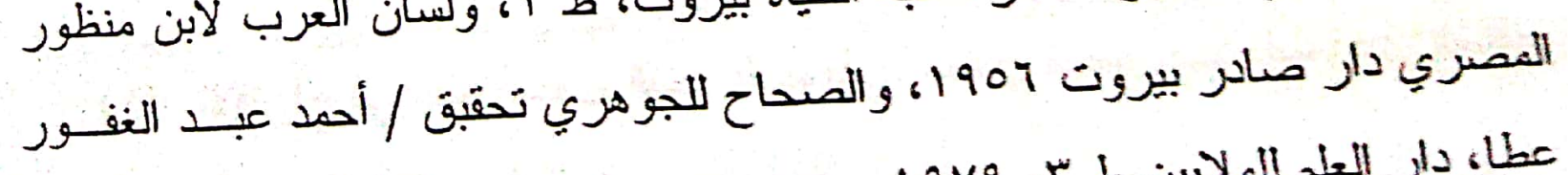

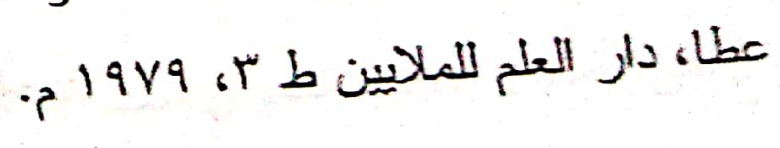
009 
تأويل، ومن نج كان مردوداً تأويل أبي على: "ليس الطبب إلا المسك " على أن

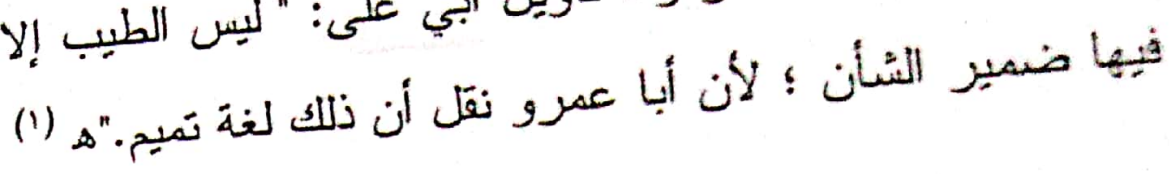

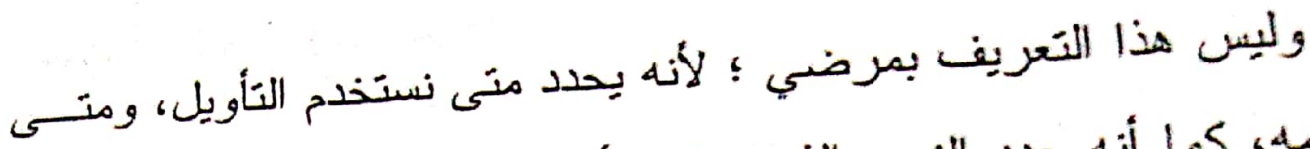

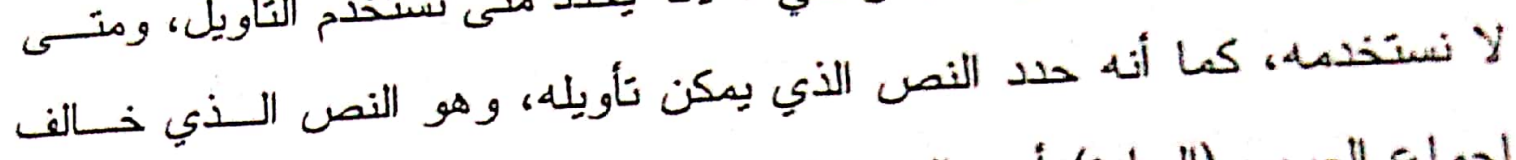

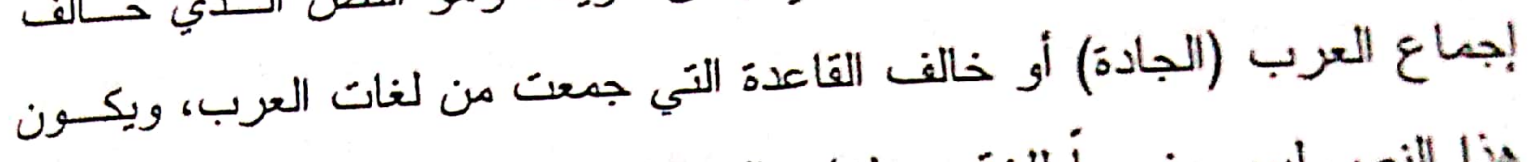

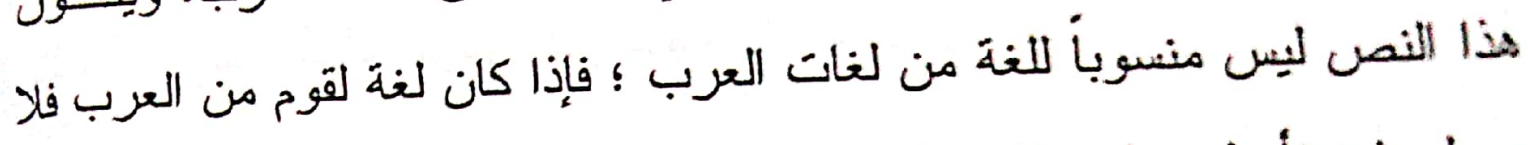
يصلح فيه تأويل، ولو خالف الإجماع.

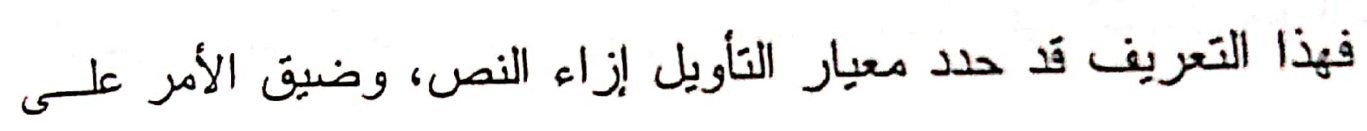
المتاول ؛ فكل كلام العرب لغات (لهجات) خرجت عن الجادة (القاعدة) فكسان يجب تأويلها حنى تتساق تحت المظلة المطردة. كما أنه تجاهل معيار المتــأول الذي بؤدى التقاويل كفكرة.

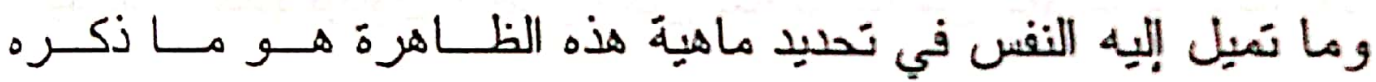
المحدثون فى معنى التاويل ؛ فقد جايت تعريفاتهم من خلال مرحلة طويلة مسن الزمن مارس فيه النحاة التأويل كعمل ذهني ينطوي على فكر مرسل لا معياري دقَيق، فقد اتسم بمعيارية فردية ذهنية، ونصوص فريدة تعد شاردة من شـوارد اللذة، يقوي فنها النص عمل الأهن، و هذا ما سلكه ابن جني في بعض تأويلاثه، وإن كنا لا ننكر على الرجل جهده العظيم في هذا المجال. فذكر المحدثن في تَنزيفه أنه:

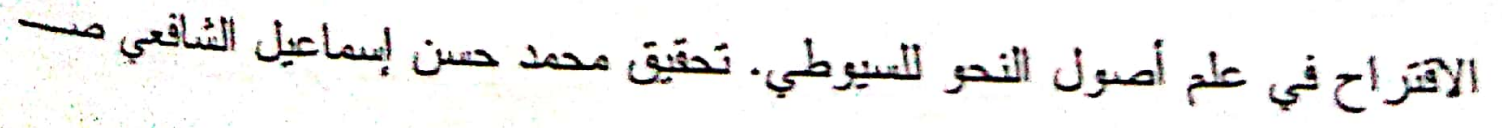
V 
وسيلة ذهنية وفنية بارعة يحالج بها النحويون الخرق الصربح اللقو اعد

النحوية و اللغوبِة المطردة.

أو هو: صرف الكلام عن ظاهره إلى وجوه خفية تحتاج لتقدير وتدبر،

وأن النحاة قد أولو الكلام وصرفوه عن ظاهره لكـي يوافـت قــو انين النحسـو

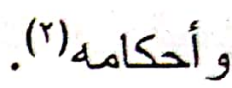

أو هو : الوسيلة التى لجأوا إليها للتوفيق بين القو اعد وبين النــصوص

(r) المخالفة لها.

أو هو : ما يطلق على الأساليب المختلفة التي تهدف إلى صفة الاتساق

على العلاقَة بين النصوص و القو اعد. (£)

أو قل: هو وسيلة اضطر ارية استخدمها النحاة فى تأويل مهـا يخـالف

قو اعدهم و أصولهم التي استمدتا من و اقعين منباينين بهدف حماية القاعدة من كل نص يخالف تزاكيب النصوص التي بنيت منها القاعدة، وحماية الأصل من كل رأي يِدمهـ.

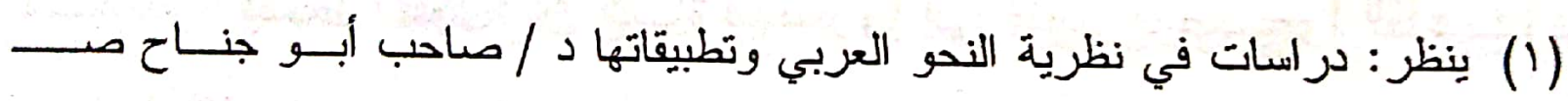

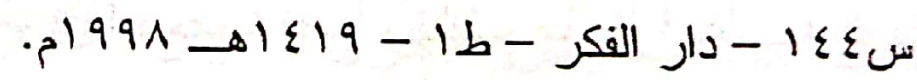

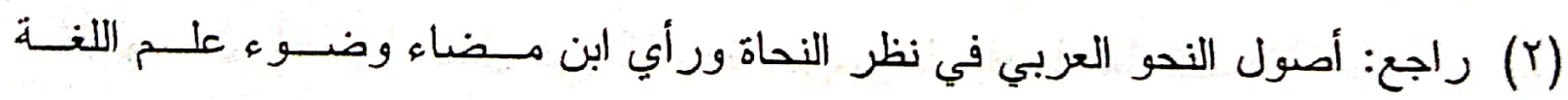

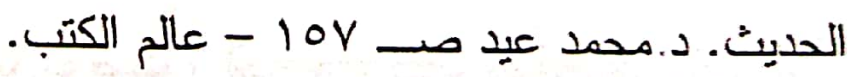

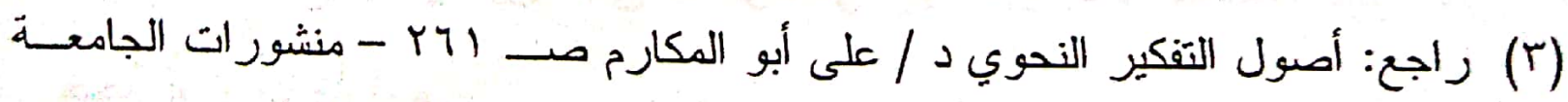

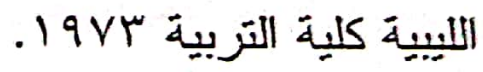
راجع: أصول التفكير النحوي صـ بـr. 
و الواقعان المتباينان هما: واقع اللغة، أي النص الـذي بــروى عسـ العرب، أو هو الكلام العربي الذي سيقت منه القاعدة وجزئياتها. و الثاني: و اقع التفكير العقلي والاستباط لمواد القاعدة (أي: دور العلماء.

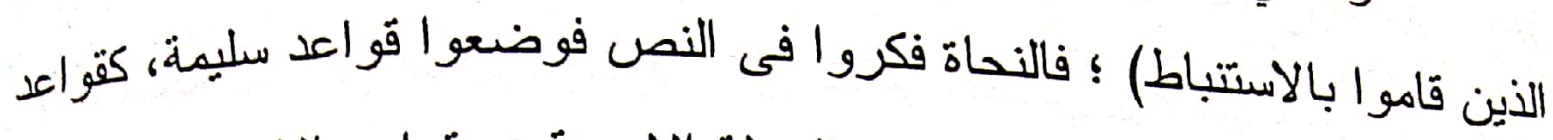
الإعراب و البناء، وقو اعد الإسناد في الجملة الاسمية ؛ وقو اعد الإسناد فى الجملة

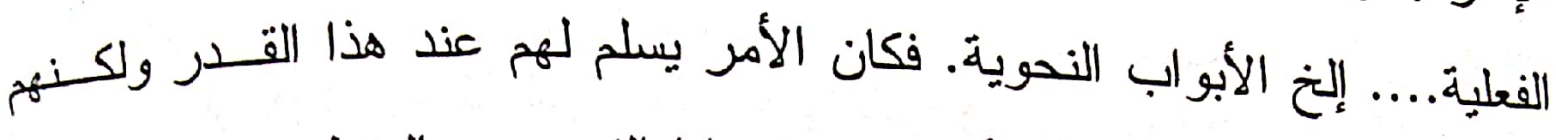
أعملوا العقل فى أمر اللغة متأثرين فى قضايا الفروع بـالمنطق - لا القـضايا

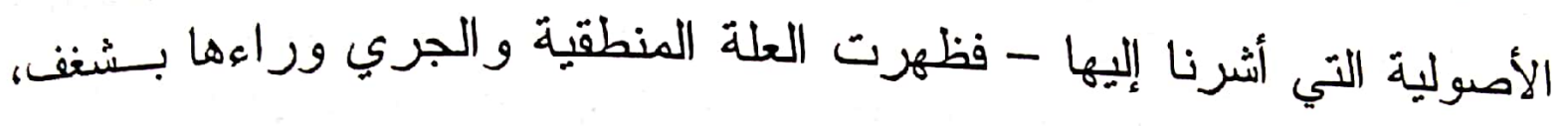
وظهرت نظرية العامل ؛ فمن القوانين المنطقية التي شغف بها النحساة، وكسـان دعامة أساسية للتأويل: قانون السبيية، ومفاده: أن لكل شئ سبياً، ولكل حسادث الثرئ محثاً ؛ فسحبوا هذا القانون على اللغة و النحو، و أوجدو اله بيئة خصبة وهـي: تعاقب حركات الإعراب تبعاً للوظيفة النحوية، وأن هذا التعاقب حدث ولا بد له من محدث ؛ ققالو ا: بنظرية العامل، وأجدوه وتأولوه إن كان محذوفاً.

وقانون عدم التتاقض قد غشي النحو بمنع اجتماع عاملين على معمول واحد، وقانون المقدمات الذي اعتمد عليه القياس النحوي...إلخ. فمجمل القول: أن النحاة قد نظروا إلى النص فوضـــوا القاعـدة دون

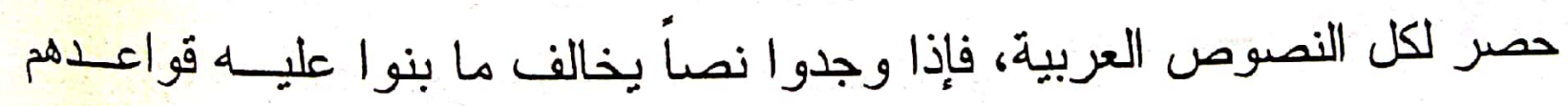
تأولوه، ثم أعملوا العقل في القاعدة فدرسوها وفصلو ها تفصيلاً عقلياً ومنطقياً ؛ فاذِ فأقاموا الحجج و البر اهين على ما توصلو ا إلبه من بناء للقاعدة، فإذا عثروا على حجة أو رأياً تأولوه. 
أرجع الدكتور محمد عيد في كتابه أصول النحو سبب التأويسل إلـى

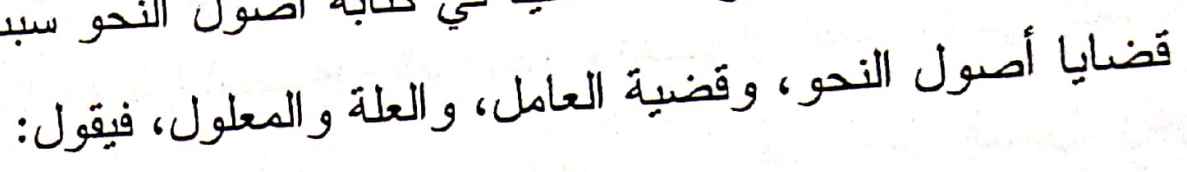

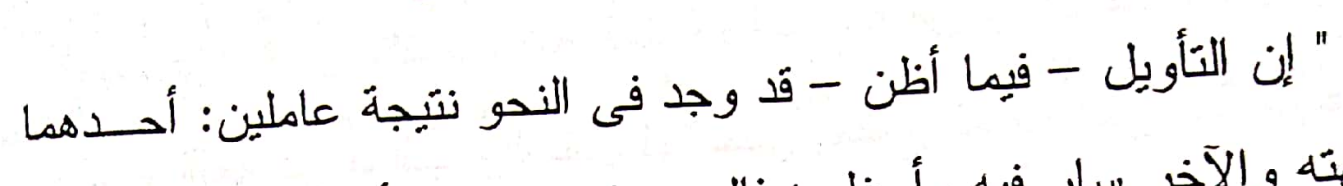

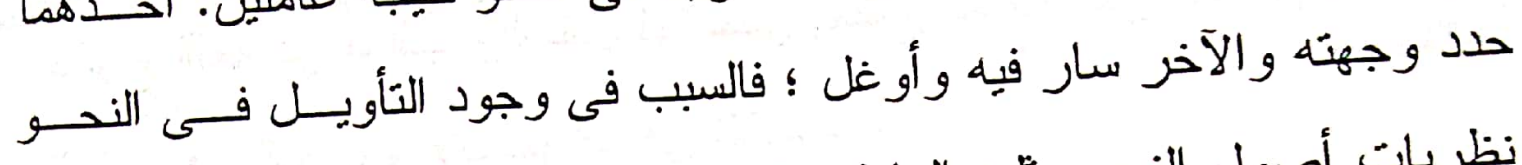

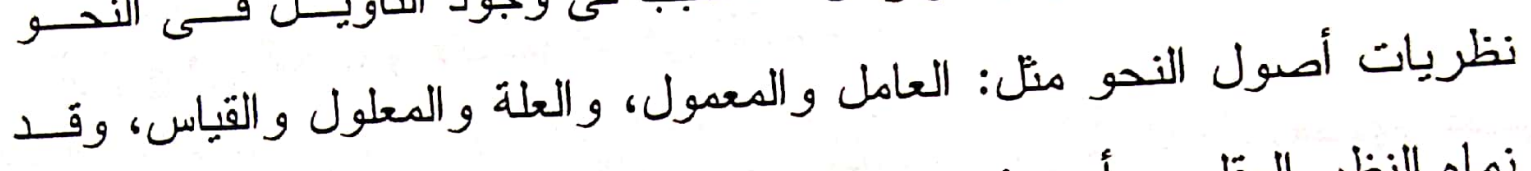

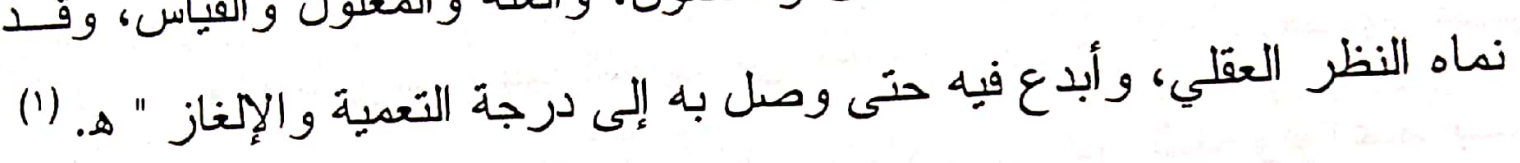

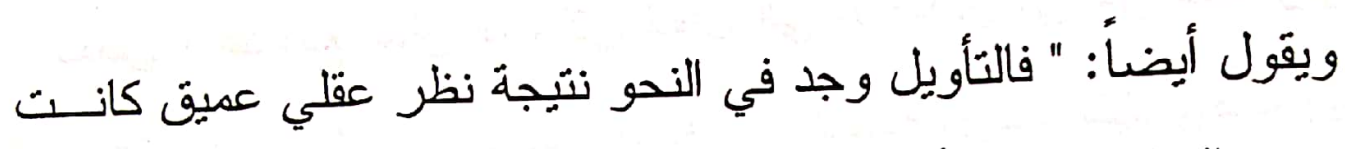

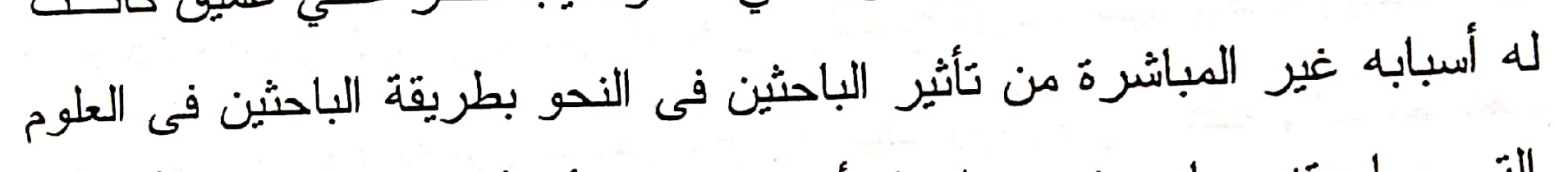

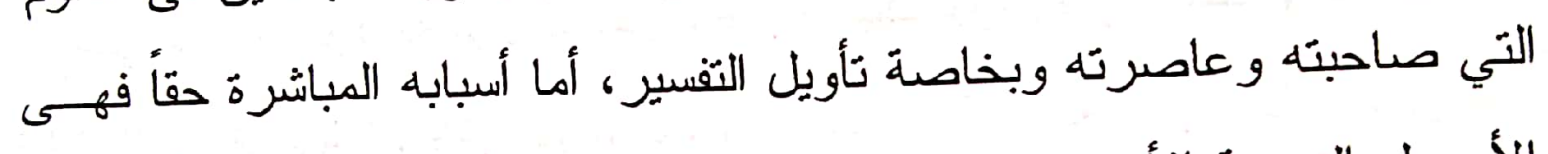
الأصول النحوية الأخرى حيث اعتصر النحاة النــصوص اللغويسـة اعتـصاراً

لتتو افق مع تلك الأصول."(r) وأعتقد أن التأويل وجد في النحو - بالإضافة إلى ما ذكر - بسسبب

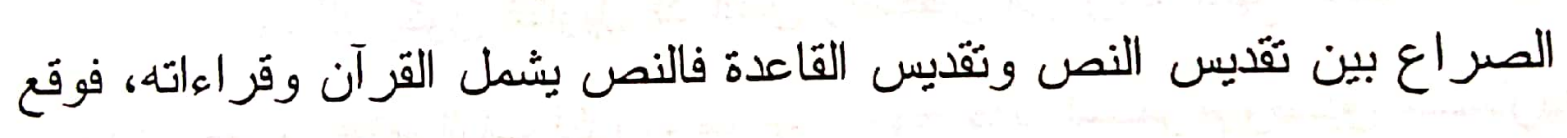
النحاة في صر اع بين رد القاعدة التي اعتمدتها نصوص أخرى كالشعر والأقوال العربية، وبين القراءة المقدسة فاضطروا إلى تأويل القر اءة بما بيتفـن و القاعـدة

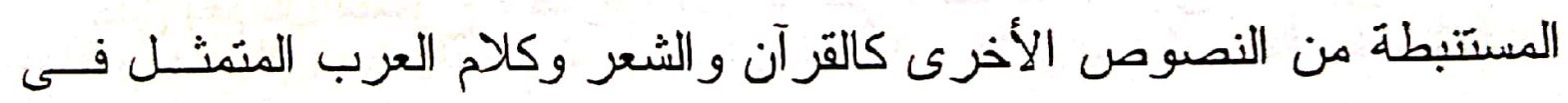

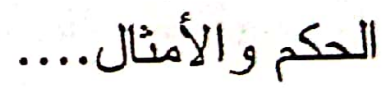

$$
\text { أصول النحو العربي صلابحا. }
$$

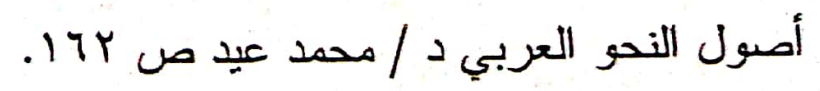




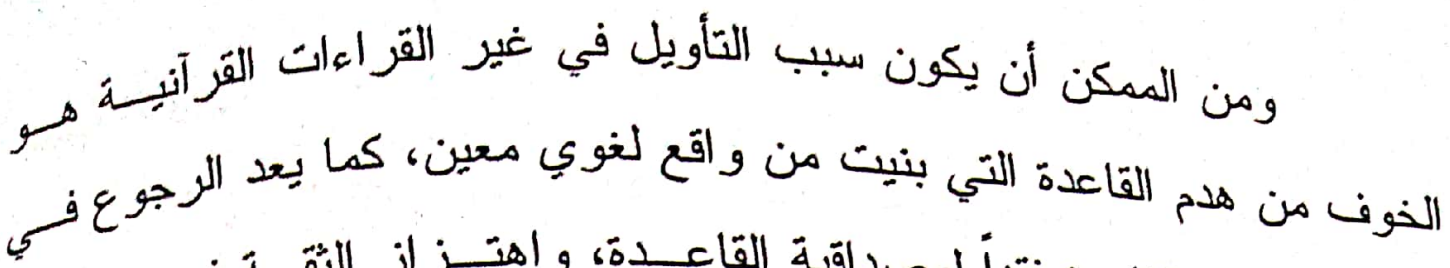

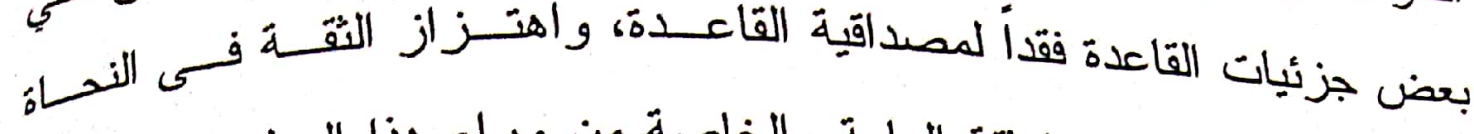
الوضاعين الذين اكتسبوا تقة العامة و الخاصة من وراء هذا العمل الجليل، وهو

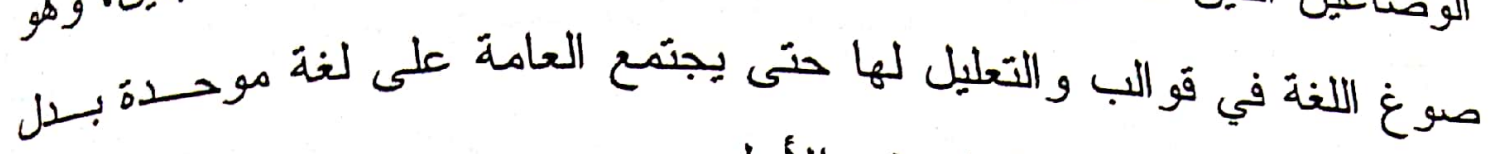
الوقوع فى اللنن، والاضطر اب فى الأسلوب.

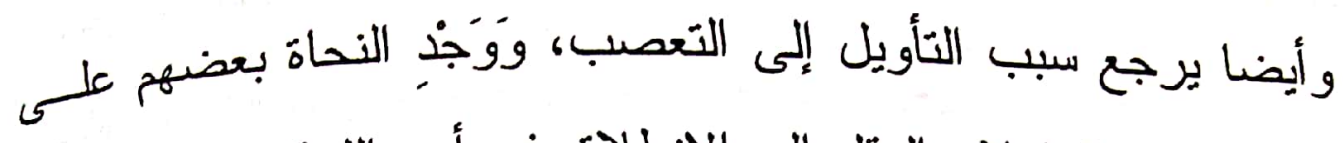
بعض ؛ فقد دفع هذان العاملان العقل إلى الانطلاق فى أمر اللغةَ وقو اعدها بسلا هو ادة ؛ فظهر التباري بينهم و التتافس، وأصبح الو احد منهم يبحث ويشظله البحث حتى يجد ما برد به قول صاحبه، فإن لم يجد جرى ور اء عقله وشسـذ ذهنسه

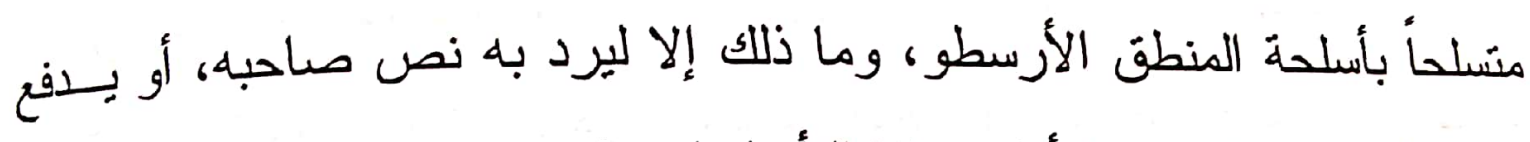

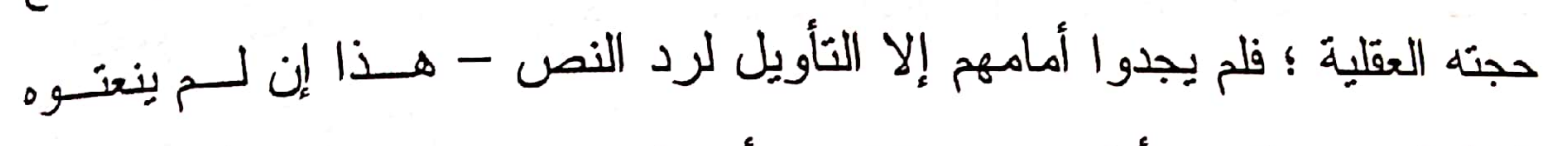
بالثذوذ - و إن قوي تأولوه حتى يتفق مع أصولهم.

وبذلك يكون التأويل قد انبثق وتمخض من رحم منهج منعدد ؛ مسنهج

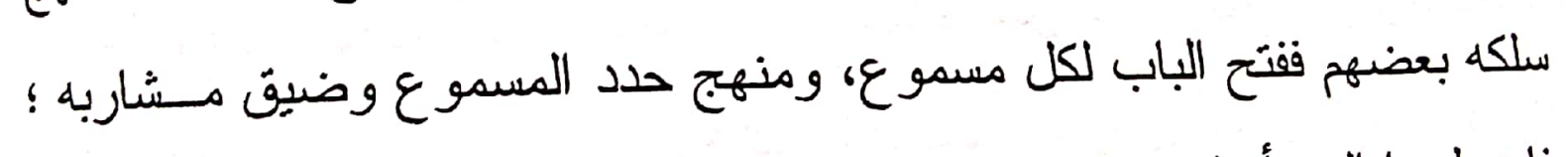
فاضطروا إلى تأويل ما خرج عن الحد، و اضطر من وسع إلى تأويل ما ضـــنَ حتى بعم كل مسموع ؛ فتأولو الآر اء التي كانت مدعاة إلى التضييقَ.

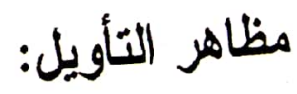

مظاهر التأويل هي: الحذف، و الاستتار ، وصو غ المصدر، و الثقدير في

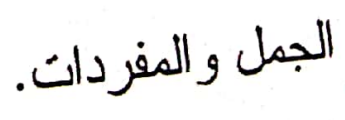


بعد الحذف من أهر مظلهز التؤويل، وقد أورده ابن جني تحت باب في شجاعة العزبية.

ثال ابن جني: " قد حذفت العرب الجملة، والمفرد، والحرف و الحركة.

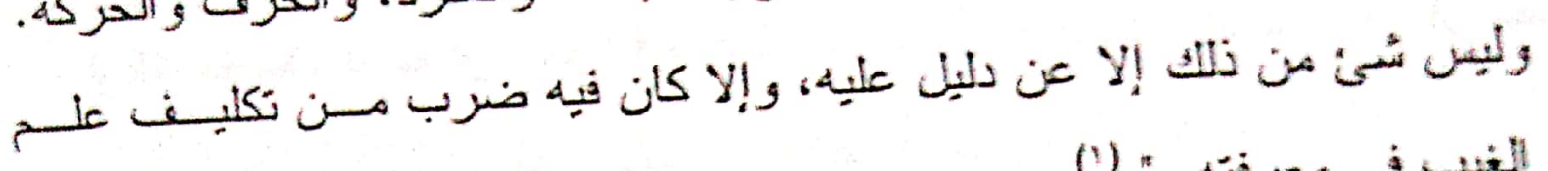

$$
\text { (1)" "الغيب في معر فتَّه. }
$$

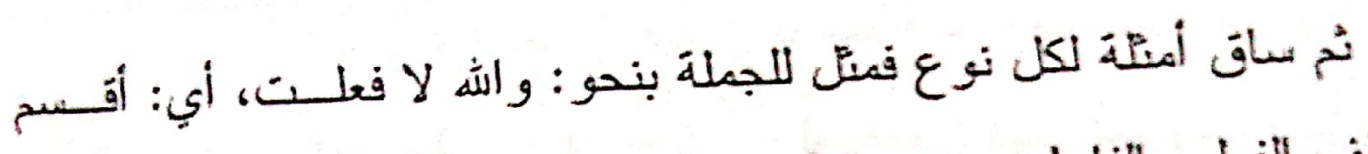

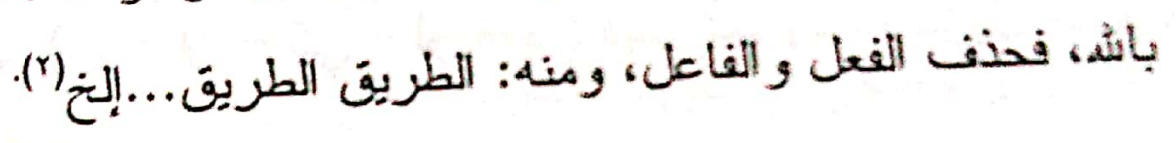

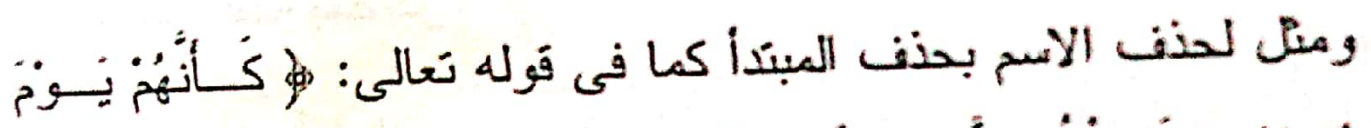

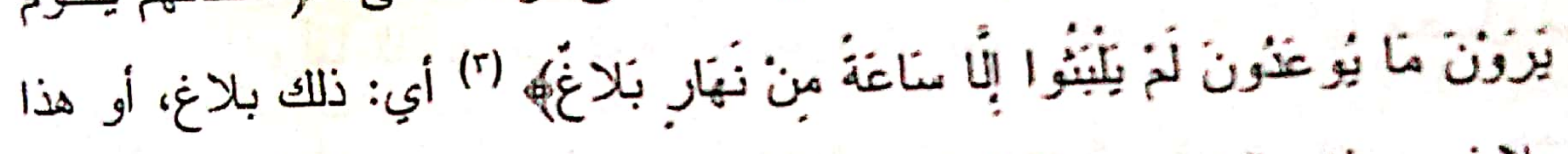

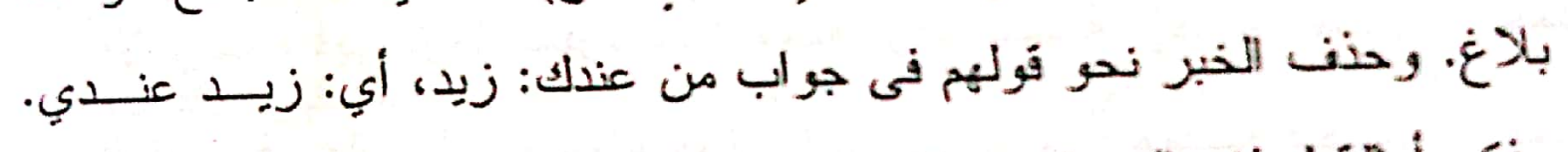

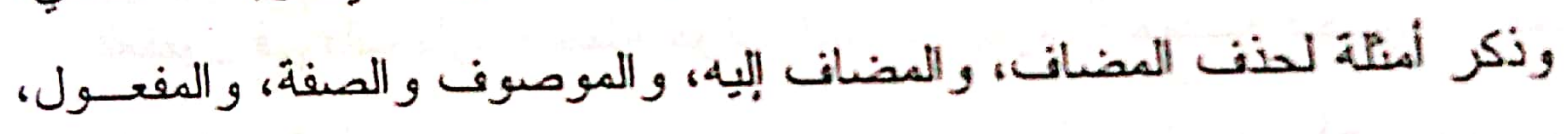

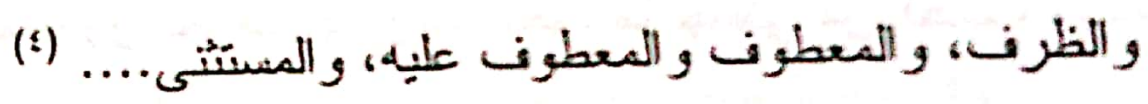

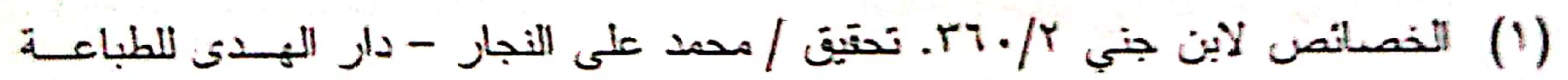

$$
\begin{aligned}
& \text { والتشز والتثزيع - بيزوت لنينان. }
\end{aligned}
$$

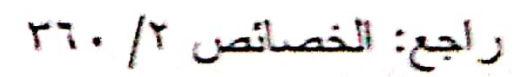

$$
\begin{aligned}
& \text { سورة الأحقاف: من الآيَة (ro). }
\end{aligned}
$$

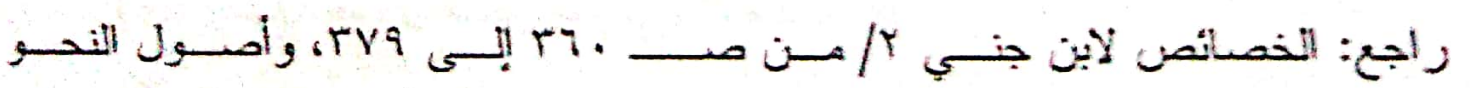

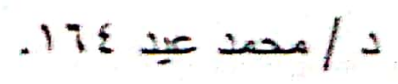

070 


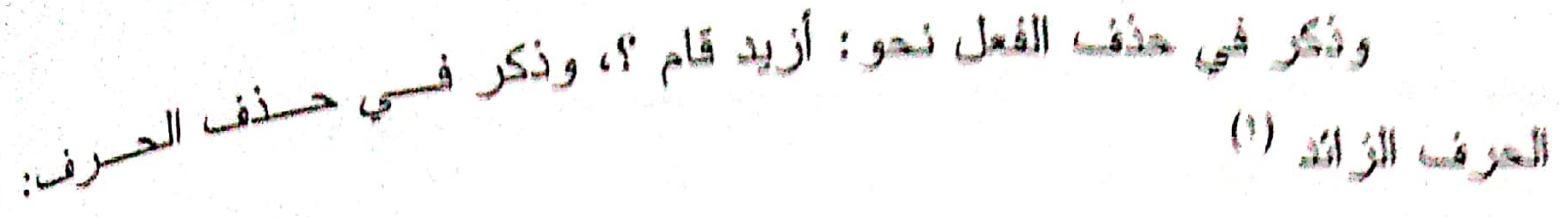

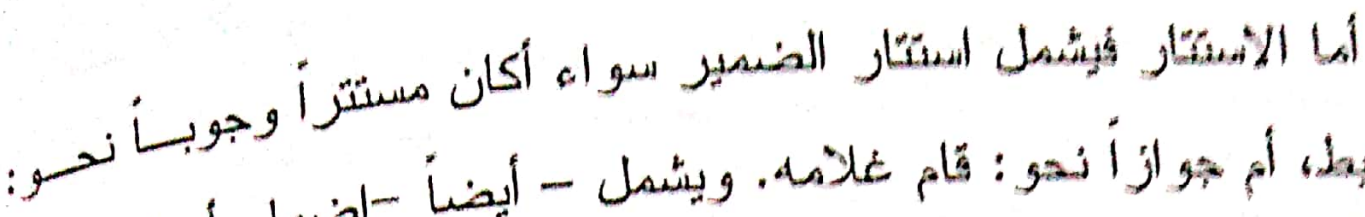

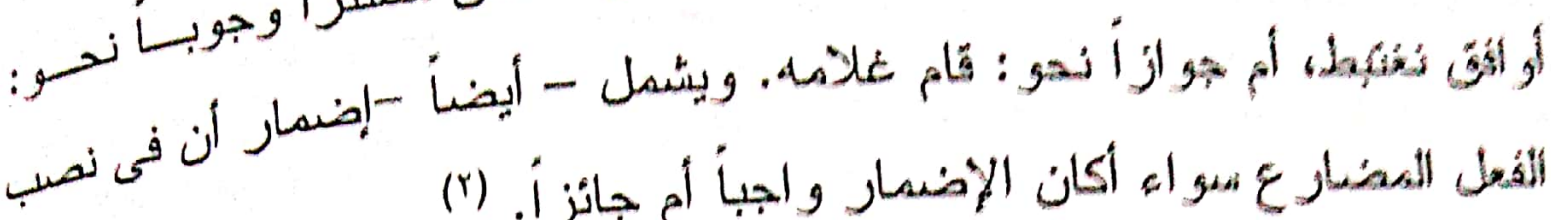

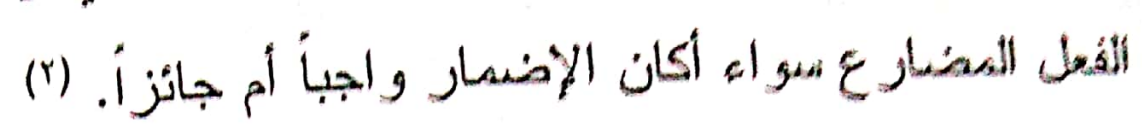

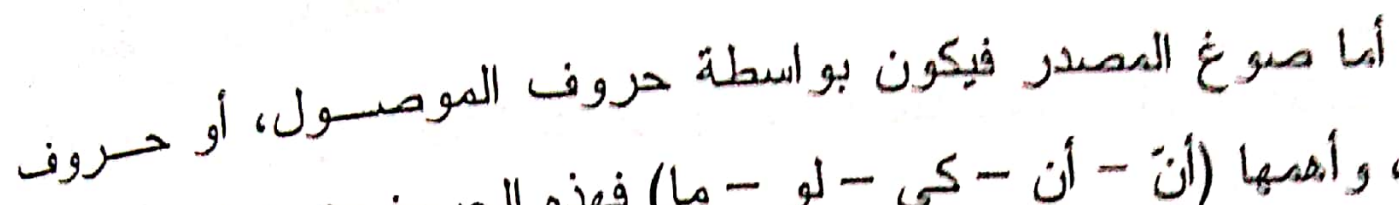

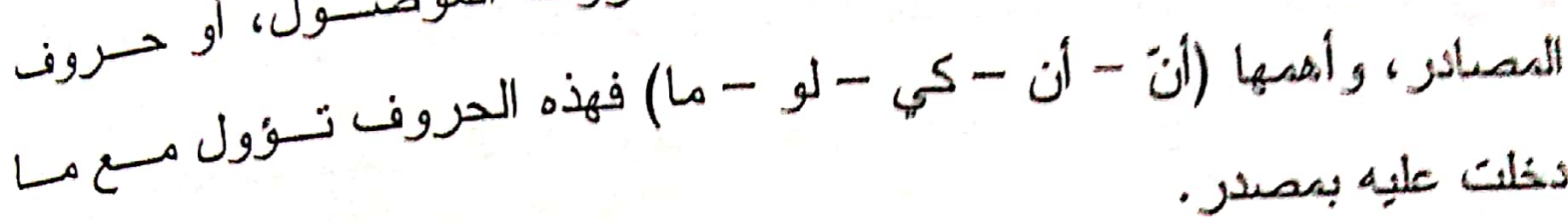
كخلت عليه بمصدر .

وأما التقدير فى الجمل و المفردات فيشمل الجمل التى لها محسل مسن

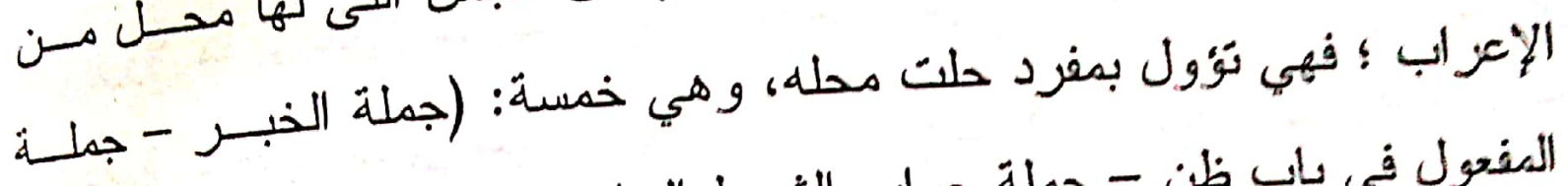

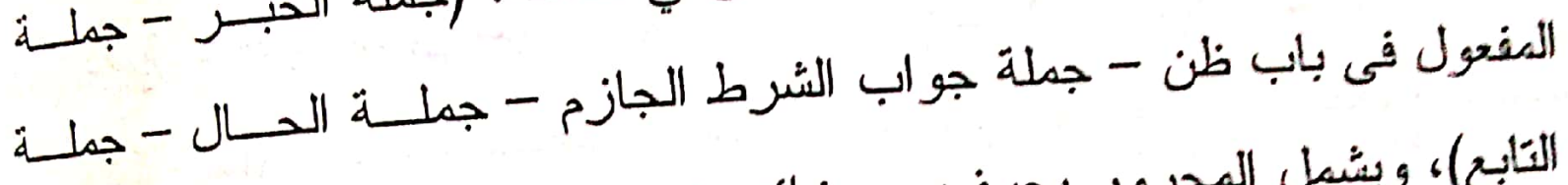

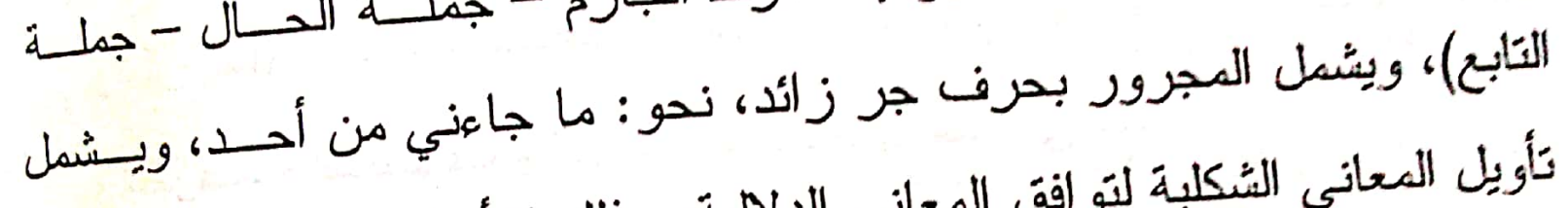

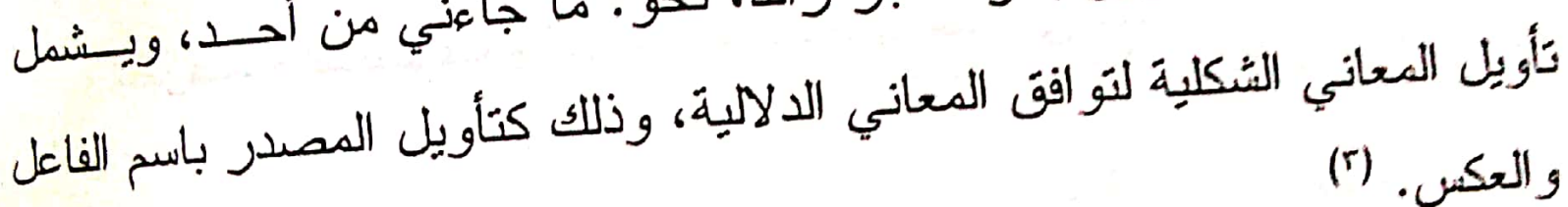

و العكس. (5)

أما هذا الحالم (ابن جني) فقد أر اد أن بخدم اللغة العربية فتجلى عن كل

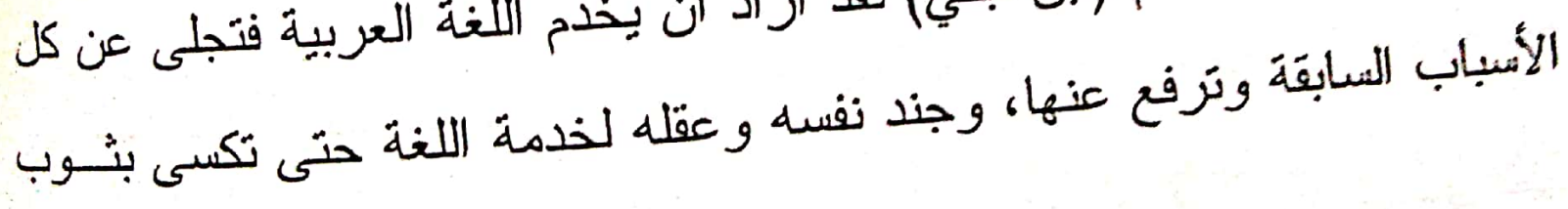

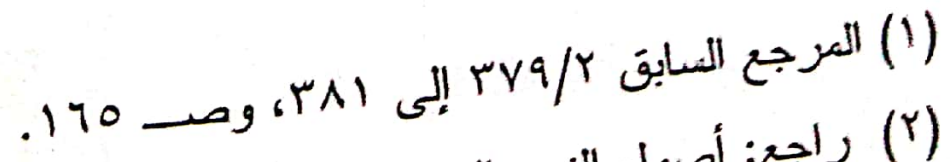

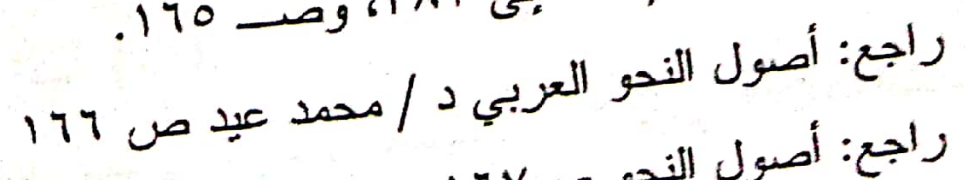


الاطر اد ؛ وما كان ذلك منه إلا من و اقع ديني انطلق من حرصسه علــى لغسة القزر آن من الخلاف و الاختّلاف. منهج ابن جني في التأويل:

سلك ابن جني فى موروثه التأويلي منهجاً معينا اسنطاع من خلاله أن

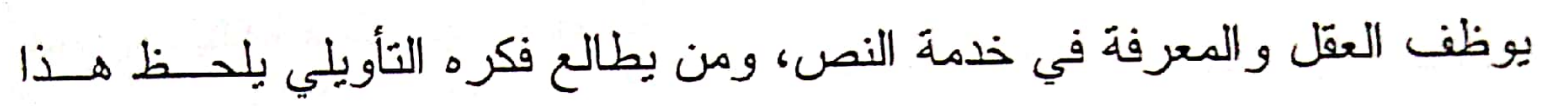

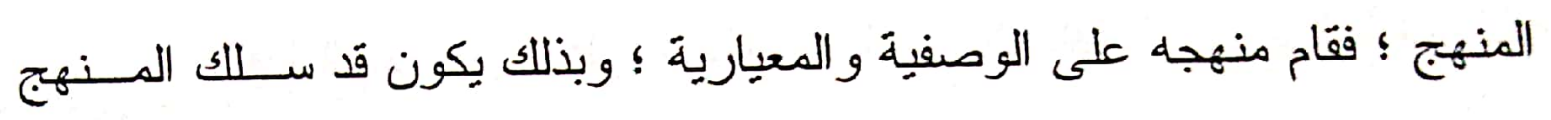
المعياري و الوصفي في تأوبله للنص. لتصن.

و المنهج المعياري هو منهج لا بكتفي بوصف الظواهر النحوية، بـلـل

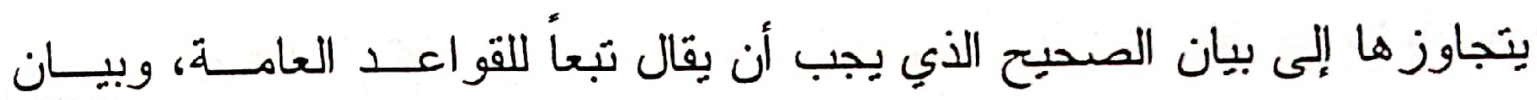

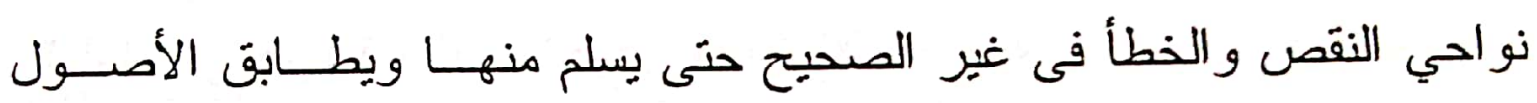

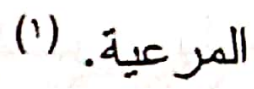

و المنهج الوصفي: هو منهج بعتمد على التجــرد و الموضـــوعية، وأن

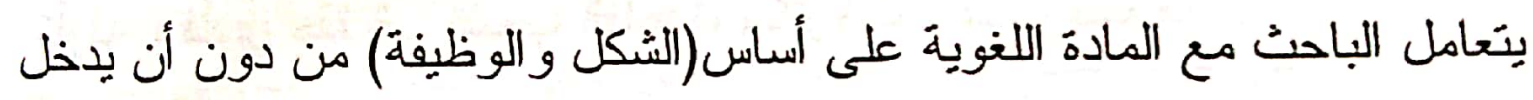
في حسبانه أية أفكار أخرى خارجة عن اللغة نفسها. (r)

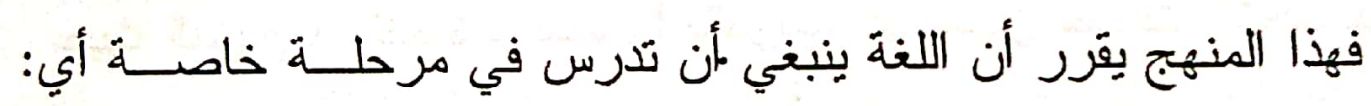

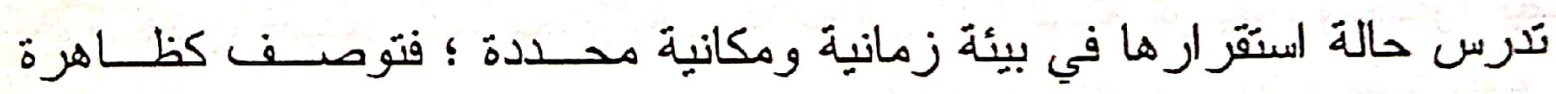

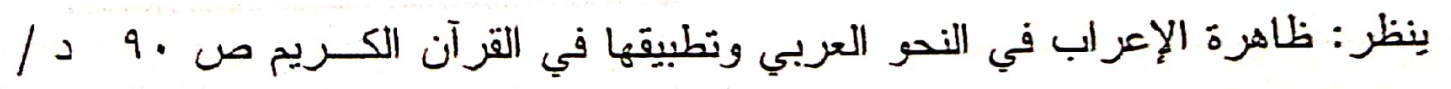
أحمد سليمان بِاقوت. عمادة شئون الككتبات - جامعة الرياض.

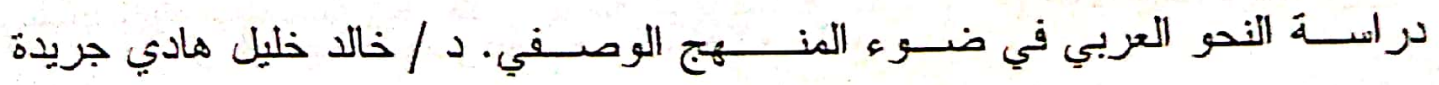

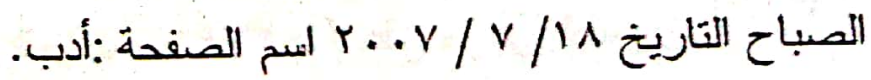


اجتماعية، وتلاحظ وقائعها وطرق تركيبها دون الحكم بالخطسأ أو بالـصواب

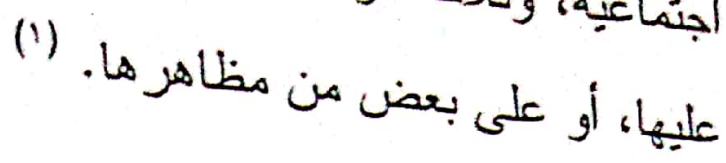

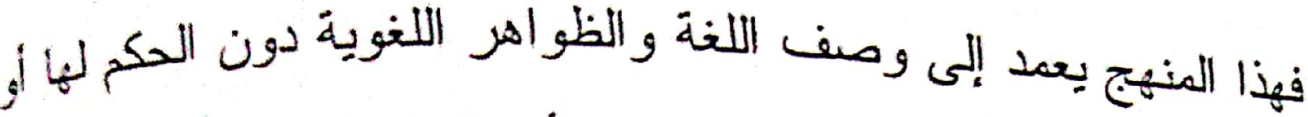

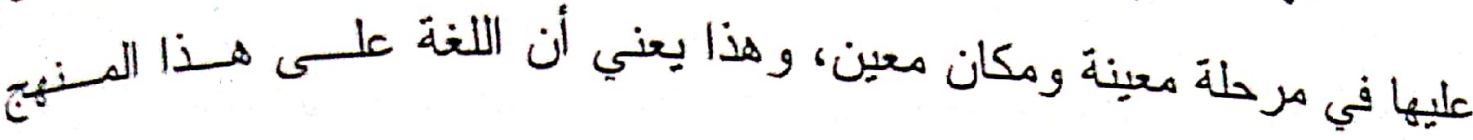
ستكرس بكافة مستوياتها المتتوعة.

و هذا المنهج يقوم على التحديد السابق بالإضافة إلى دراسة اللغة بكافة

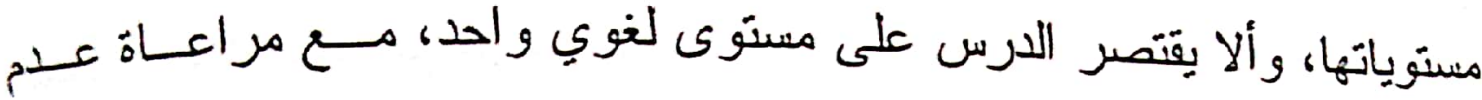

الخلط في مستويات التحليل اللغوي.

وهذا لا يتَفق مع طبيعة التقعيد النحوي، أو قَل: لا يتفق مع ما يئن منه

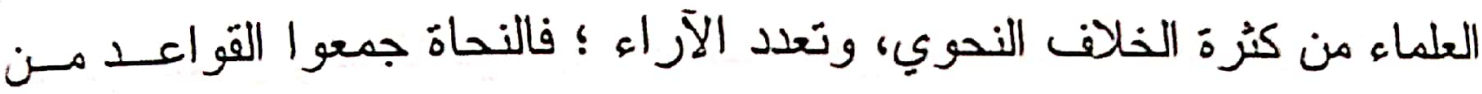

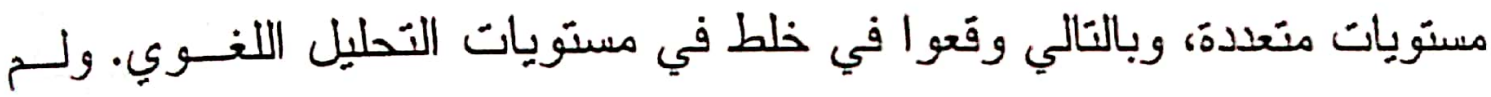
يلتزموا بمنهج معين في عملية الجمع و التقعيد فما أقره فريق رفضه الآخــر أو تأوله ؛ فأدى هذا إلى تشعب القاعدة، وكثرة الدذاهب ولئ والخلافات.

فهذا المنهج يخالف صنيع النحاة من حيث الموضوعية، ويو افقهم مسن

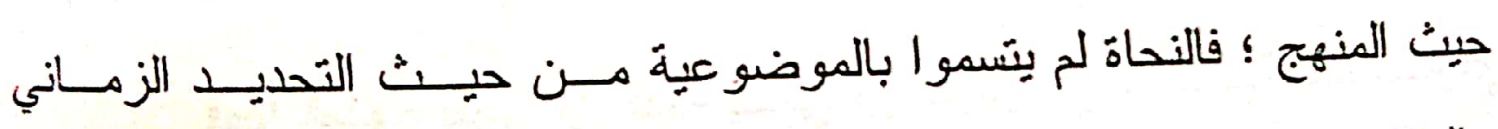
والمكاني، فاختلفو افيما بحتج به وبكلامه من أهل المائة الرابعة، واختلفوا أيضاً فيما بحتج بـه من أهل العرب.

(1) ينظر: الفكر الندوي عند العرب أصوله ومناهجه صـ ؟Y ع د / على مزهر الياسري

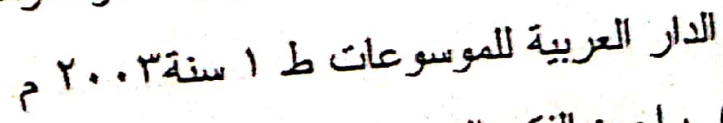

(r)

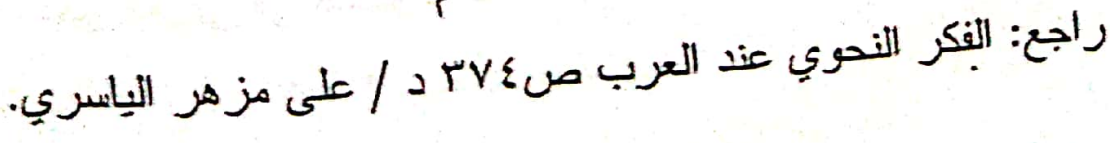


أما اتفاقهم من حيث المنهج فكان منهج النحاة في دراسة اللغة يتطرق

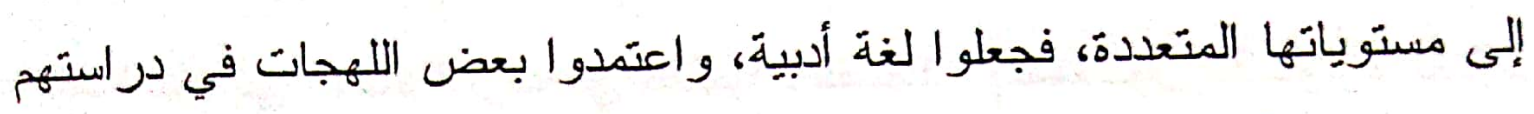

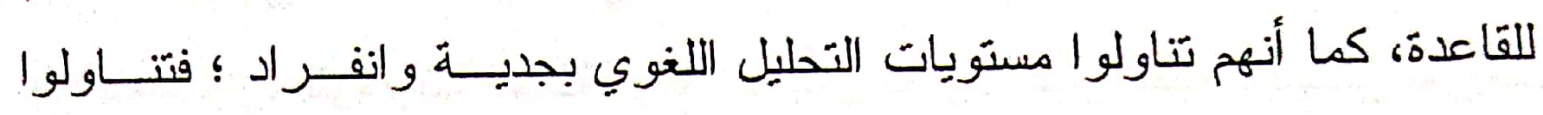

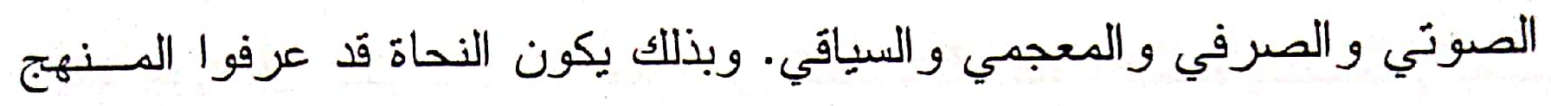

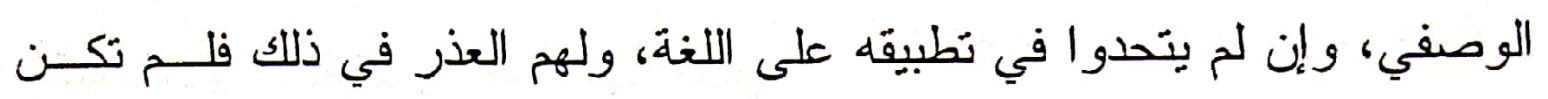

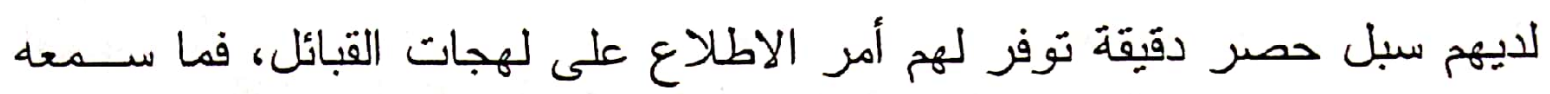

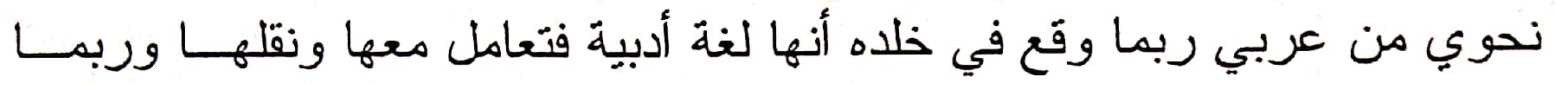
بنيت عليها أمور نحوية، وامتذ بها جسر الخلاف إلى أجيال وأجيال. ولنضرب لذلك بعض النماذج التي تذل على أن ابن جني عالم تفــرد

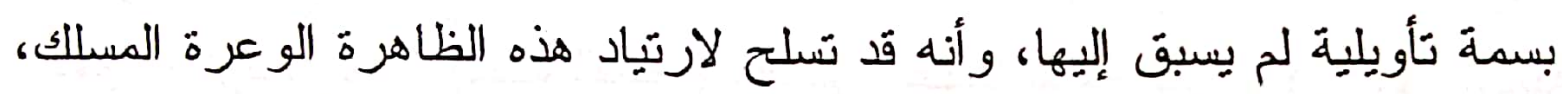

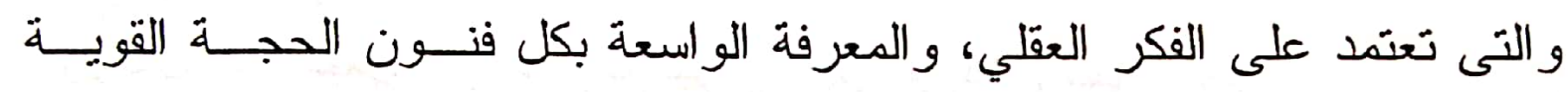

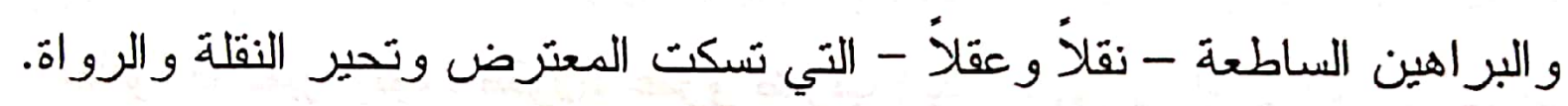
- كما سنوضح فى آليات التأويل -

ومن هذه النماذج التي اعتمد فيها ابن جني المنهجين السابقين:

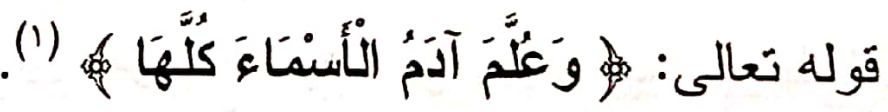

فقد اعتمد ابن جني في هذا النص الذي أراد تأويله المنهج الوصــفي، فأخذ يصف النص ويحلله لعله يجد له مخرجاً لعله يندرج تحت القاعدة المطردة المعمول بها في اللغة ؛ فاستتد في هذا إلى شيئين:

سورة البقرة: من الآية (اس"). وهي قراءة يزيد البربري كما في المحتسب لابن جنـي 
الأول: الكلام الإنشائي وهذا ما تلحظه من أول نظرة نقر أ فيها كلاهه، فقد استند إلى اهتمام العرب في كلامها بالفضلات (المفعـول) فـأولوه العنايسة

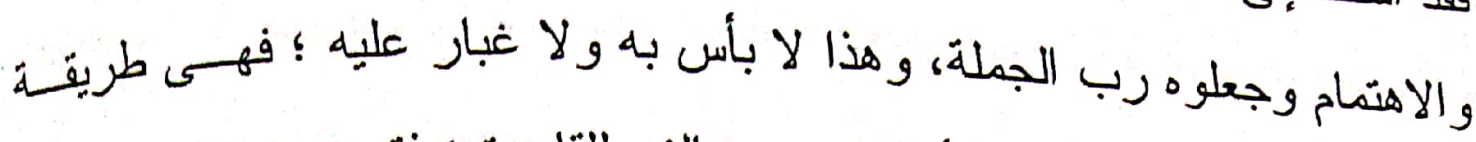
يلجأ إليها كل عالم إذا وقف أمام نص مخالف للقاعدة ؛ فتجده بـستخدم عتلـه.

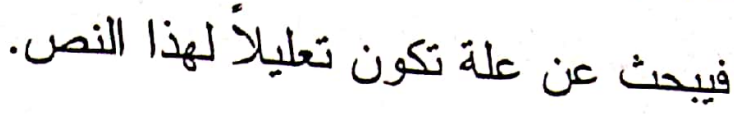

الثاني: الواقع اللغوي و هذا يتمثل في تغيير النمط التركيبي للجملة حين

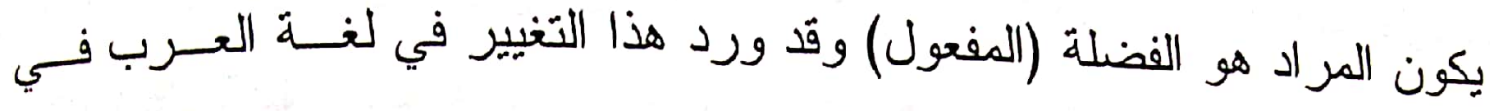
نمطبن مختلفين: الأول: عندما ير اد المفعول فيكون الحديث عنه و لا يراد الفاعل

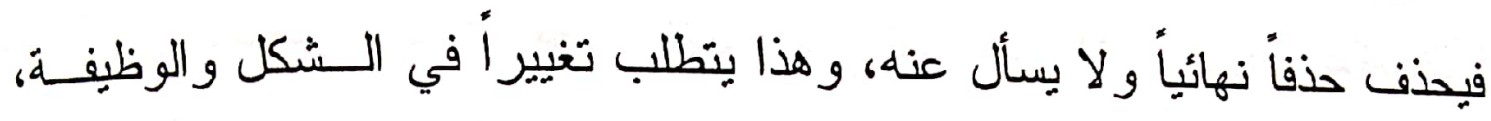

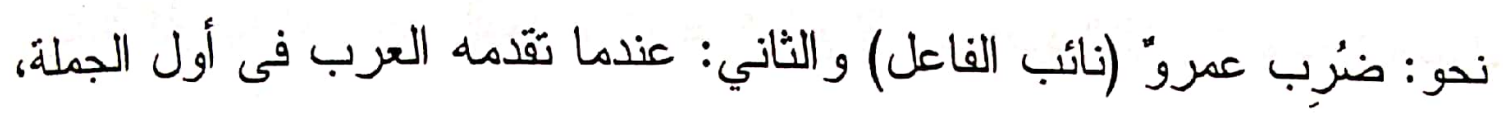
ويشغل عنه الفعل وتزفعه (هع جواز نصبه ورفعه) نحو : عمرو ضربه زيد، ثم

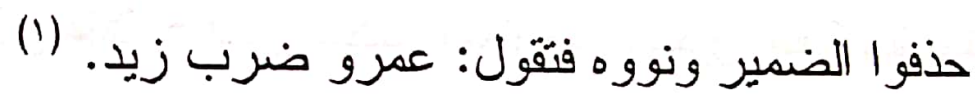
ونستطيع أن نلمس من كلام ابن جني - الذي وقف فيه أمسام الــص

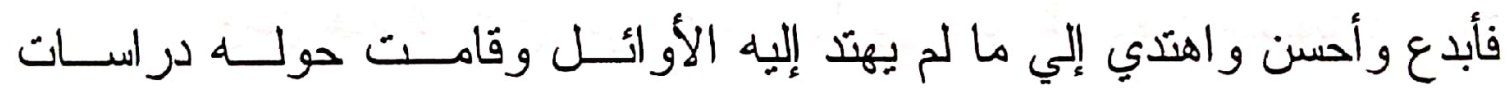
المتأخرين و المحدثين - أن العرب تصرفت في الرتب حسب منطلبات الـسياق،

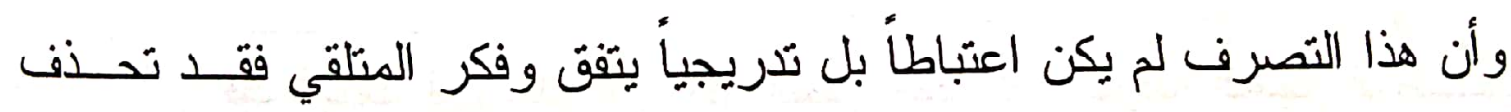

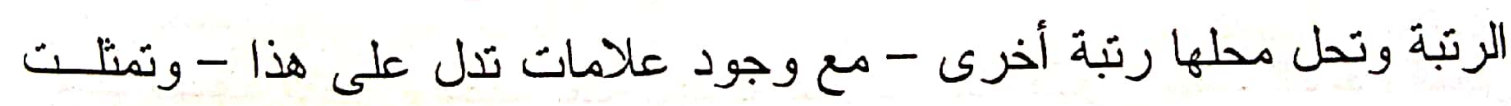
هذه العلامات في الشكل و الوظيفة. 
وتصرفوا أيضاً فى الرنبة فقدموها ولم يكن هذا التصرف إلا محكمسن

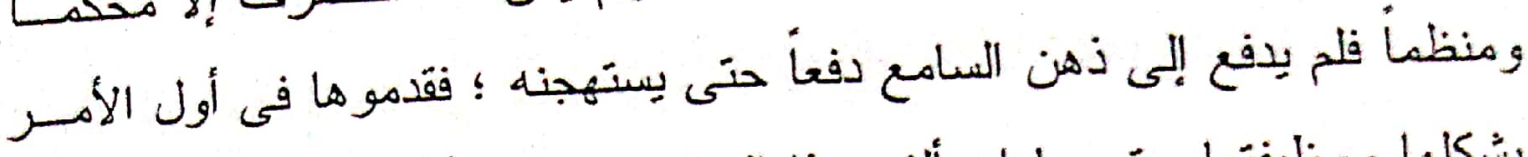

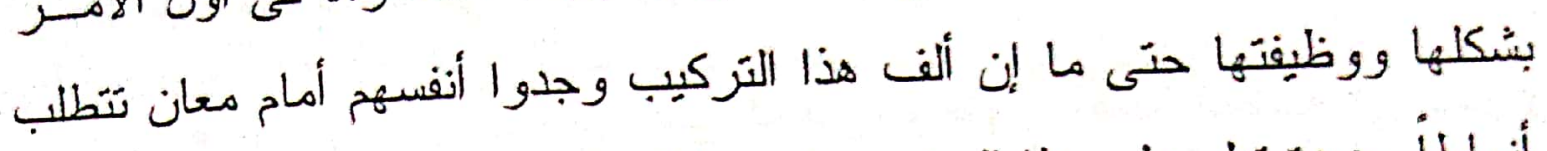

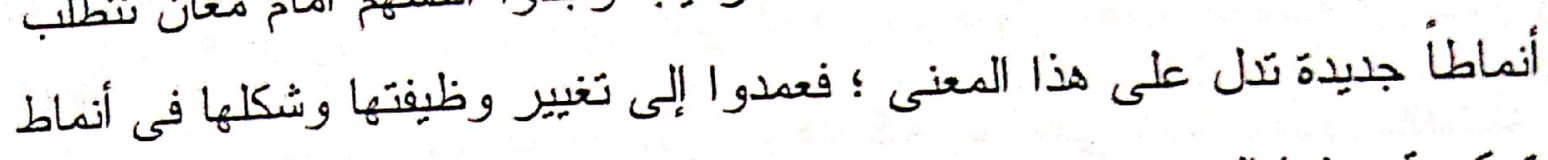

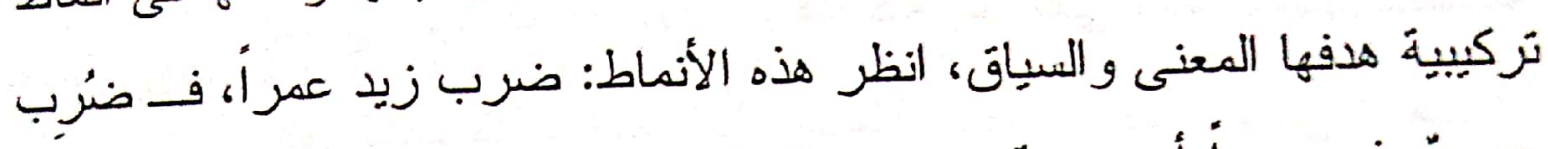

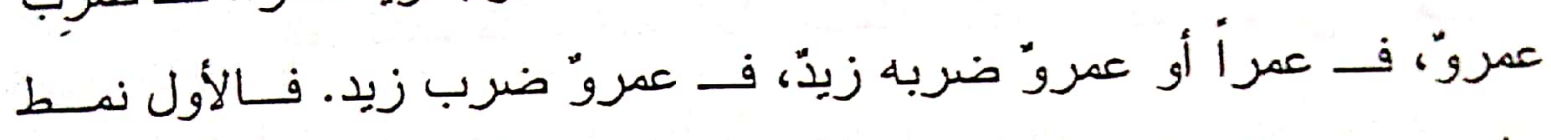

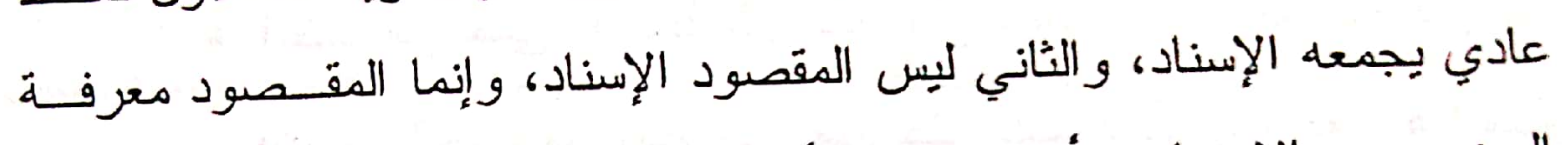

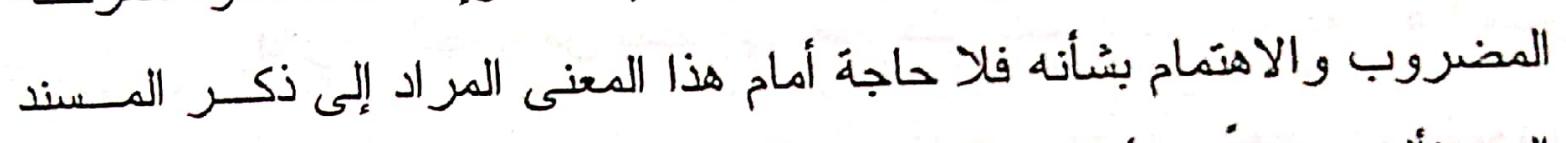

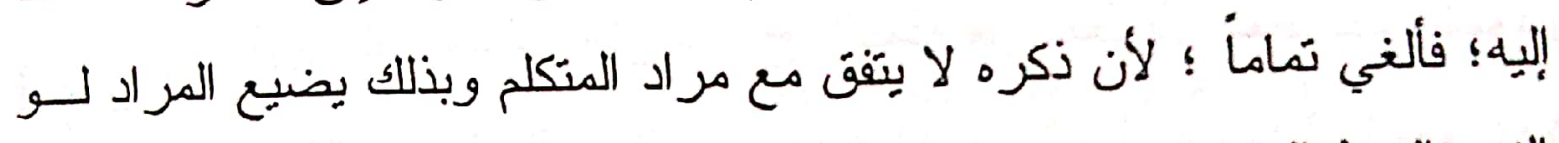

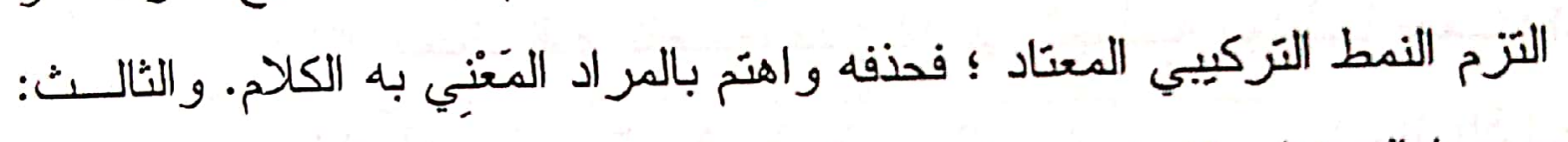

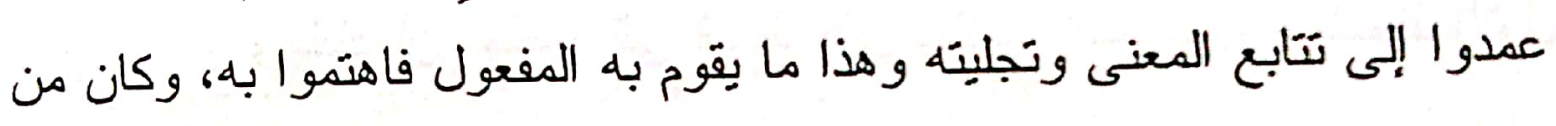

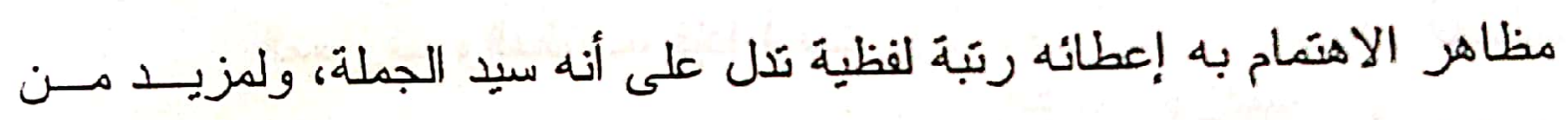
العناية غيروا المثكل فرفعوه. وسأورد نص ابن جني في ذلك حتى تلحظ ما ذكرناه: قال: ".... أصل المفعول أن يكون فضلة وبعد الفاعل.... فإذا عنـاهم ذكر المفول قَدموه على الفاعل.... فإذا ازدادت عنايتهم به قدموه على الفعـل

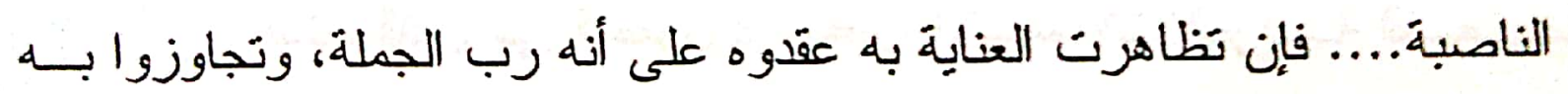

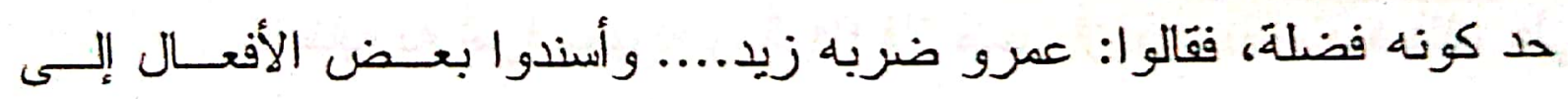

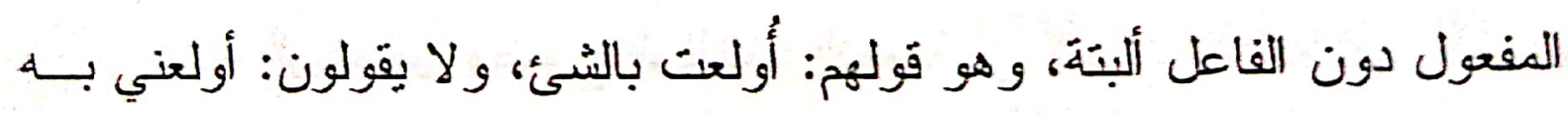
كiا... 
وقد اعتمد ابن جني فى هذا النصل المنهج الوصفئ فوحف الطل و علل لها، وقد لوحظ في تحليله ووصفاه ما ياتئ:

• أن ابن جني قد ركز على المعنى، و إخلهار أهمية الفضلة: في إيراز

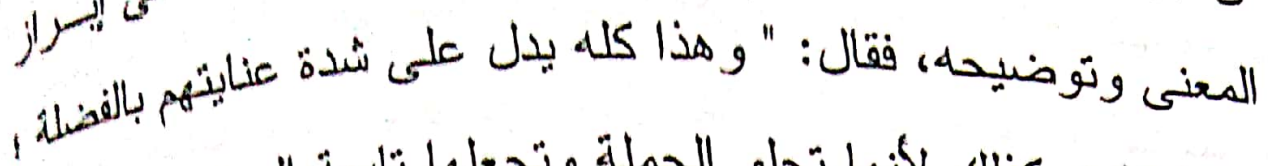
و إنما كانت كذلك لأنها تجلو الجملة وتجعلها تابعة المعنى ". هـ (1)

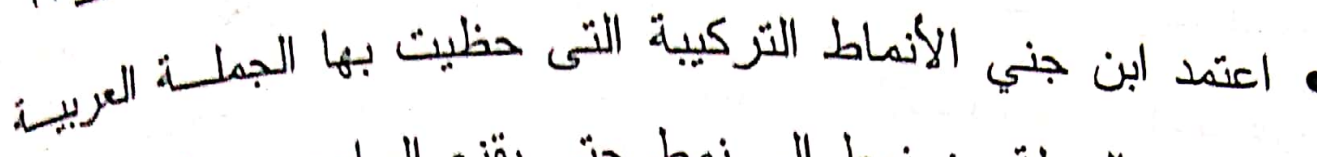
فتّر ج بالجملة من نمط إلى نمط حتى يقنع السامع، وجعل هذا مسن فبيل المسامحات التى تثدر ج بالجملة من نمط إلى نمط حنى نسؤدي. جملتك معناك الذي تقصده، فكأن للك فى الجملـــة أنماطسنا منعسلدة. و عليك أن تخلص إلى النمط الذي يلأيــم المعنــى، فــالنمط الأول: المعروف و المألون، فإذا أردث مزيد معنى للك أن تستخدم أنماطنا أخرى. نحو: ضرب زيد عمرأ، أو عمرأ ضرب زيسـد، أو عمسرو ضربه زيد...إلخ.

استخدم ابن جني إحلال الوظائف النحوية محل بعضها مـــع التبيـة على ذلك بتغيير البنية التركيبة، كما حدث فى النص السابق، فجـل إسناد الفعل إلى المفعول فى بعض الاستـعالات العربيــة الفـصبدة للعناية به أمراً معهوداً ومألوفا؛؛ فلا ضير أن يَرِذَ نص بعد ذلك على الرغم من وضوح الوظائف النحوية فى النص،، وأن حــنف أهــها 
ليس بالضروري، والكنه جعل الإحلا لغرض معنوى مع الاستئنس

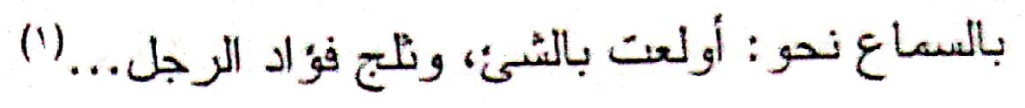

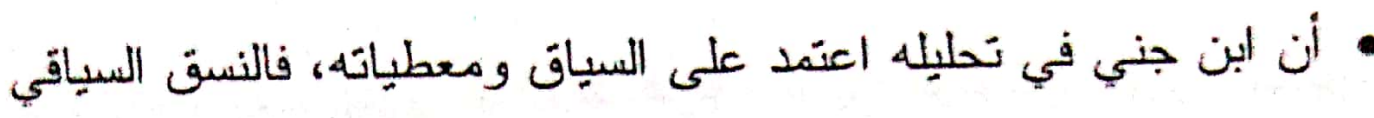

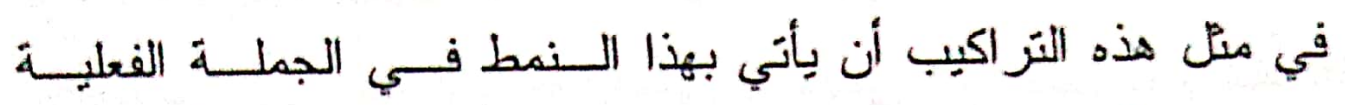

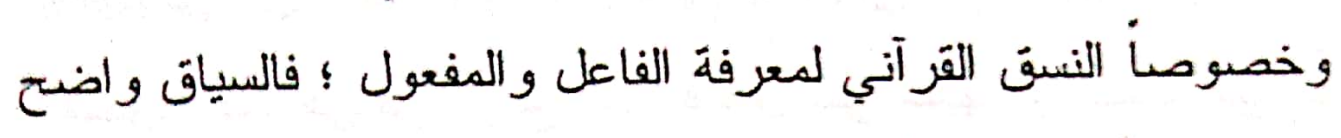

و المعنى مألوف لذللك أنت بالذيار فى اختيار أي مسلك تسلكه، فــإذا

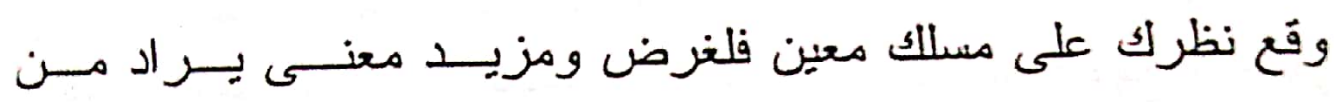

التركيب. وذكر لذلك أمثلة - بالإضافة إلى النص السابق بقراعتيه -

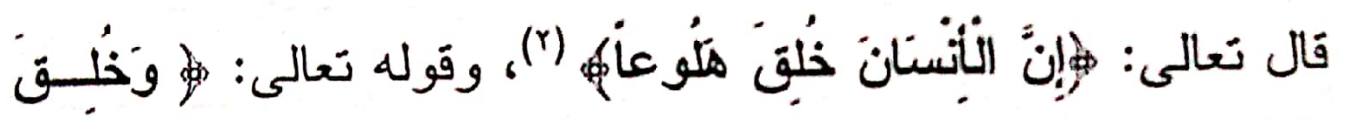

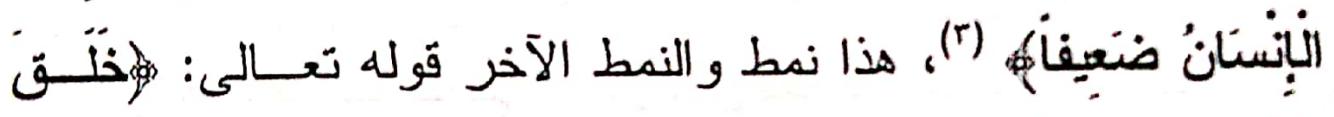

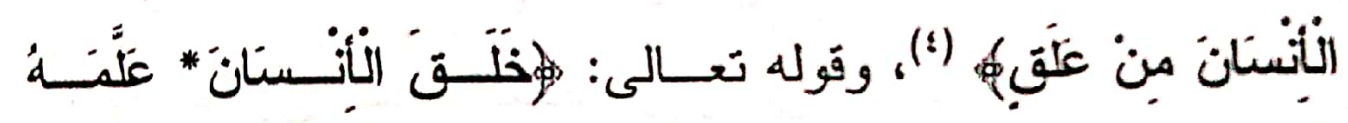

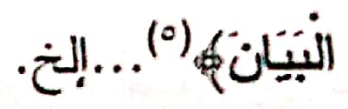

و علق على ذلك بقوله: " فقد علم أن الغرض بــذلك فـى جميعسه أن

الإنسان مخلوق ومضعوف، وكذلك وَلهم: ضُرب زيد إنما الغرض منه أن بعلم

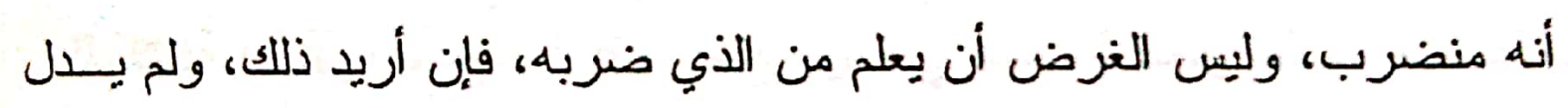

$$
\begin{aligned}
& \text { راجع: المحتسب 10/7. } \\
& \text { (1) سورة المعارج: الآية (19). } \\
& \text { سورة النساء: من الآية (Y) } \\
& \text { سورة العُقَ: الآية (r). } \\
& \text { سورة الرحن: الآيتان (T، ؟). }
\end{aligned}
$$

orr 
دليل عليه فلا بد أن بذكر الفاعل فيقال: ضرب فلان زيدأ، فإن لم يفعل ذليك

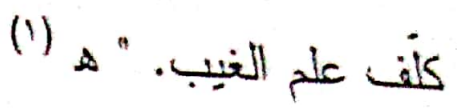

وبهذا يكون النحاة قد عرفوا المنهج الوصفي، وليس كما يزع بهضض

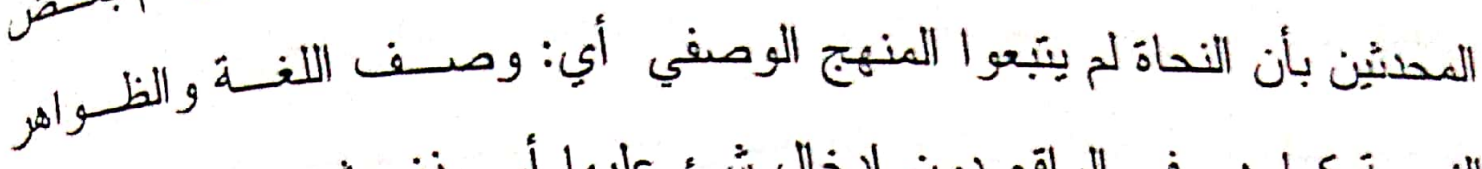
النحوبة كما هي فى الو اقع دون إدخال شئ عليها أو حذف شئ منها، بل التبعا

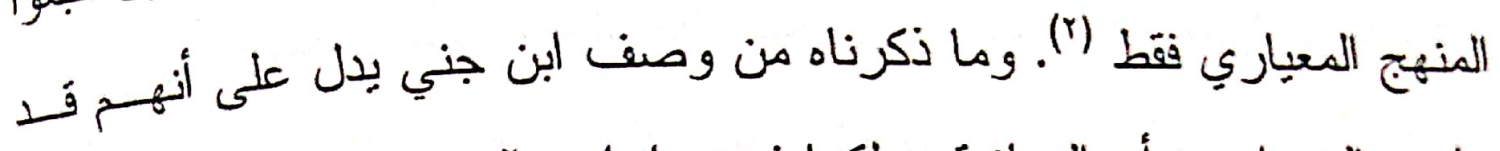

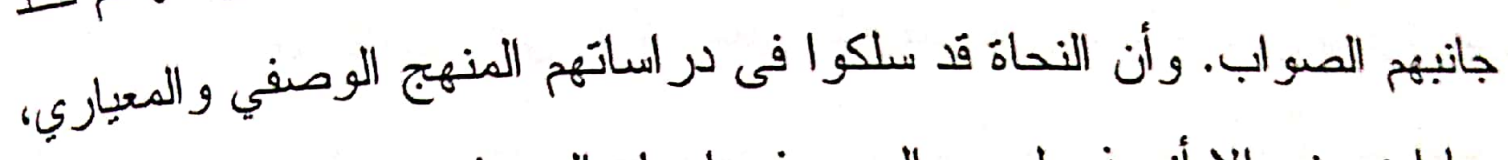
وما ابن جني إلا أنموذج لهم. و السبب فى إدعاء المحدثين هذه الدعوة تزجع إلى

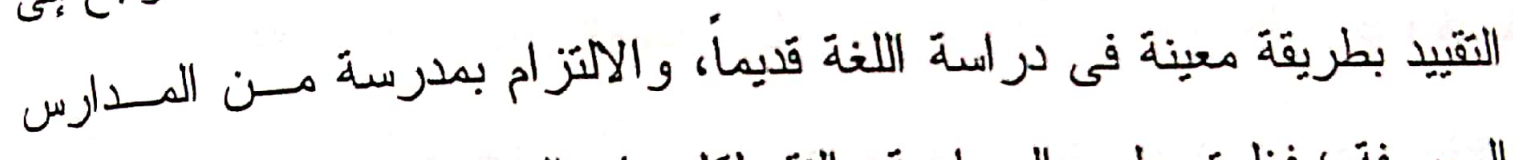

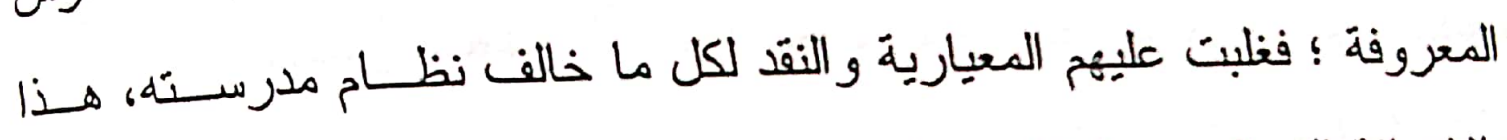
بالإضافة إلى التحديد المكاني و الزماني للغة فهذه المعيارية (معياريسـة الزمسان

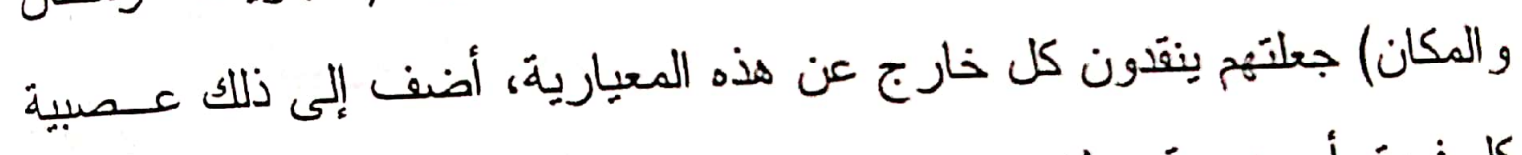
كل فريق أو مدرسة جعلتهم بهدمون كل ما تبنتهَ الأخرى.

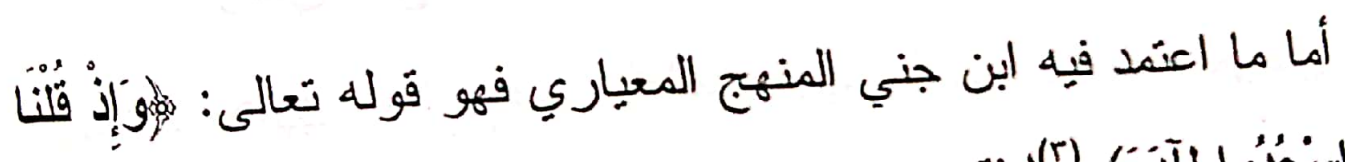

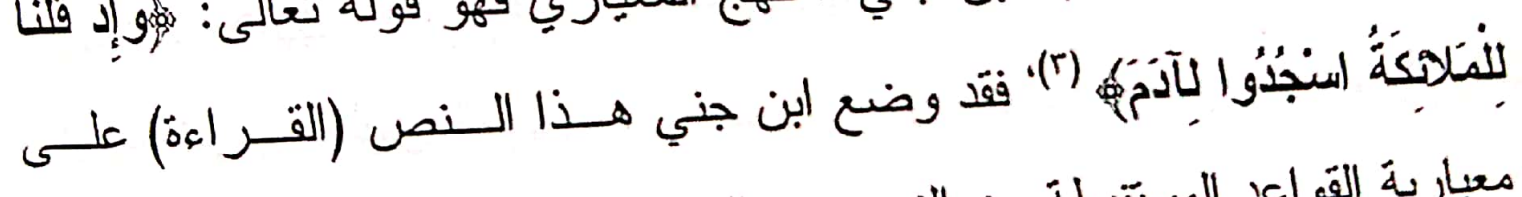

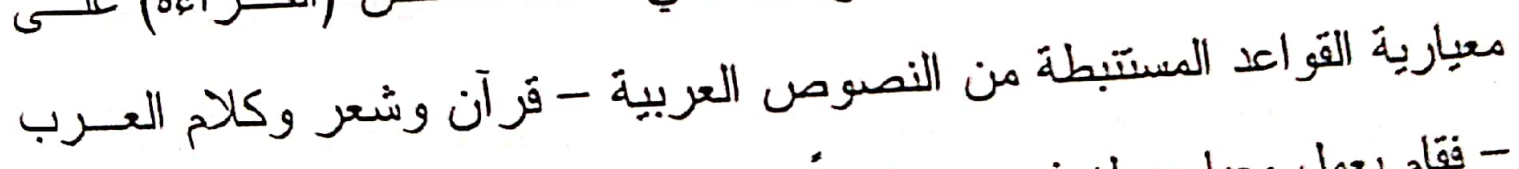

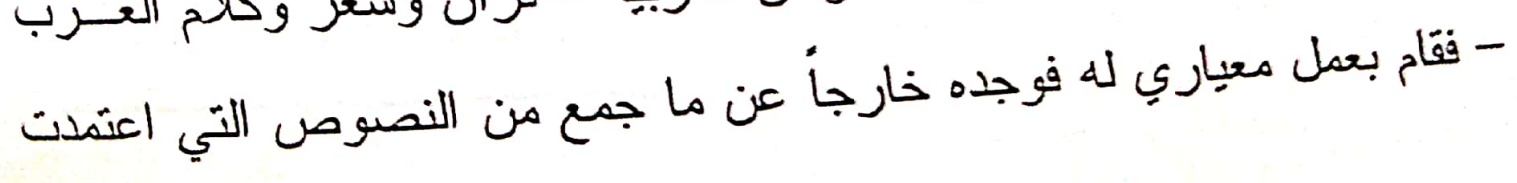

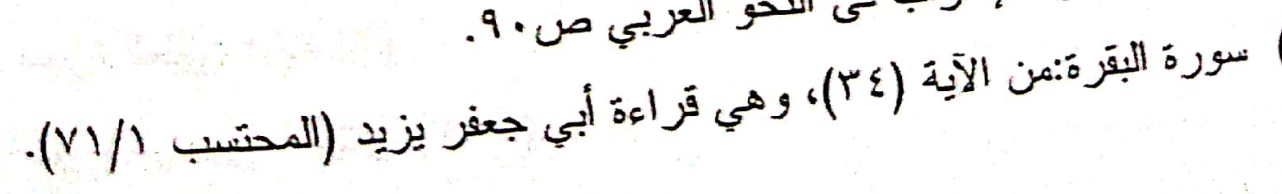


في صوغ القاعدة ؛ فأصدر حكمه فيه بناء على موازنة بينه وبين غيـره مـن النصوص، فقال: " هذا ضعِف عندنا جدأ. " هـ (1)

و علل لحكمه هذا بقوله: " وذلك أن الملائكة فى موضع جر، فالتاء إذا

مكسورة، ويجب أن تسقط ضمة الهمزة من (اسجدوا) لسقوط الههزة أصسـلاً إذا كانت وصلخ." هـ (r)

ثخ رد على ما بِكن أن يُظن أو يُخرج عليه هذا النص، وهو جواز أن

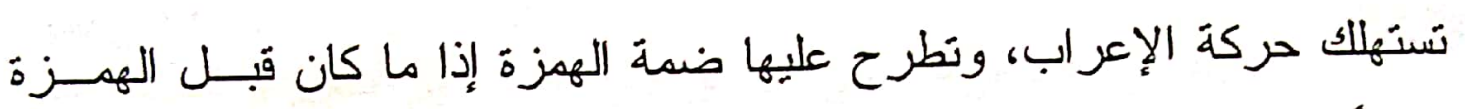

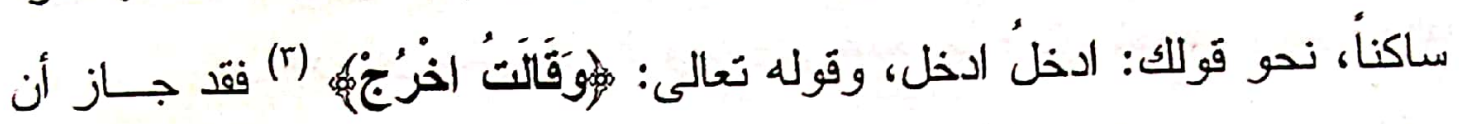

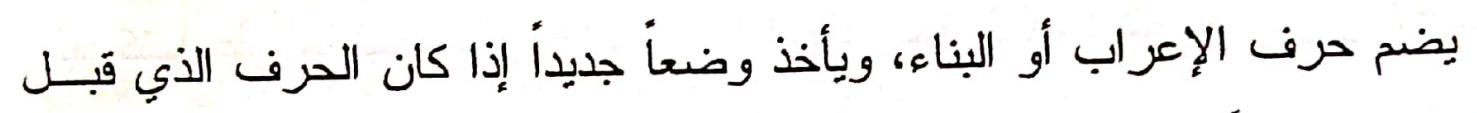

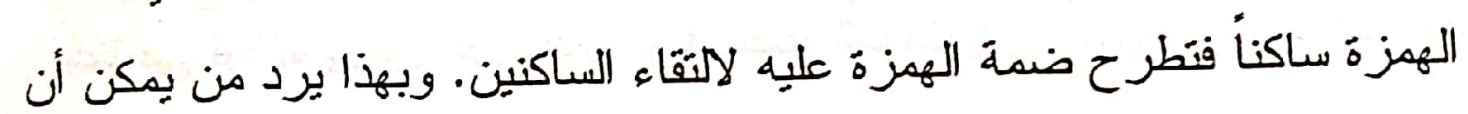

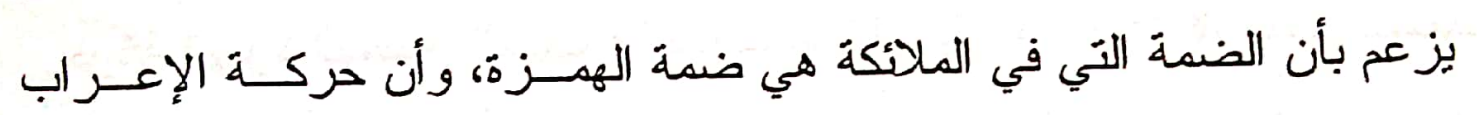

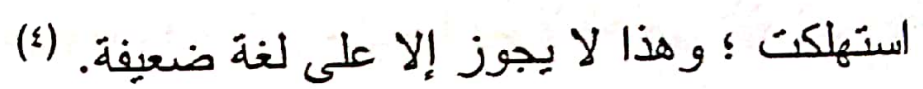

وقالن: " فهذا التخفيف مع النقل إنما يكون إذا كان الأول الملقى ساكنا،

فإما إذا كان متحركاً فقد حمته حركته أن يقبل حركة أخرى غيرها ".

$$
\begin{aligned}
& \text { المتسب لابن جني: VI/ } \\
& \text { المرجع السابق. } \\
& \text { سورة يوسف: من الآية (الr). } \\
& \text { المحتسب: V)/ } \\
& \text { المرجع إلسابق المبا }
\end{aligned}
$$

ovo 


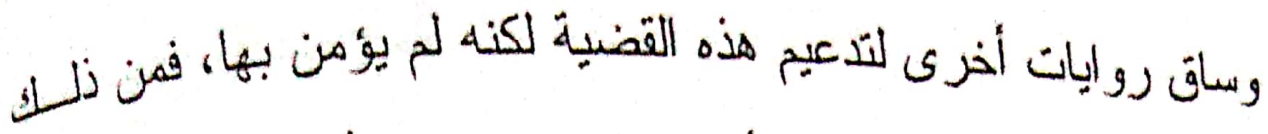

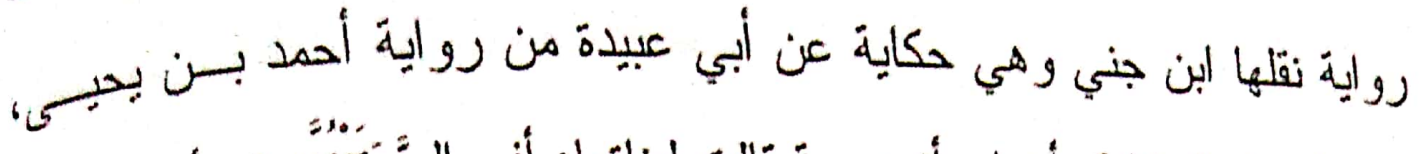

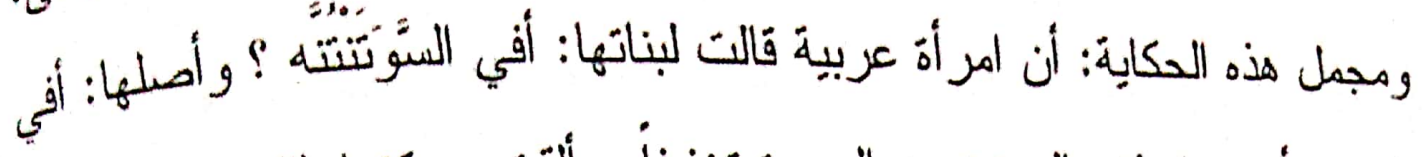

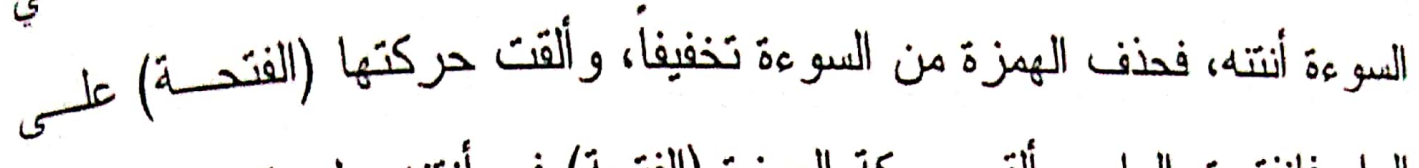
الواو فانفتحت الواو، وألقى حركة الهمزة (الفتحة) فى أنتته على كسرة التاء من السوة فانفتحت، وحذقت همة أنتته فصارت: أفي السوتتنته. هكذا قال أحمد بن

(1). بحيى.

ورفض ابن جني هذه الرواية ولم بقتتع بها ؛ لأن تخفيف الهمزة و إلقاه

حركتها على ما قَلها جائز إذا سكن ما قَبلها، وساق لذللك أمتلة من القر آن الكريح

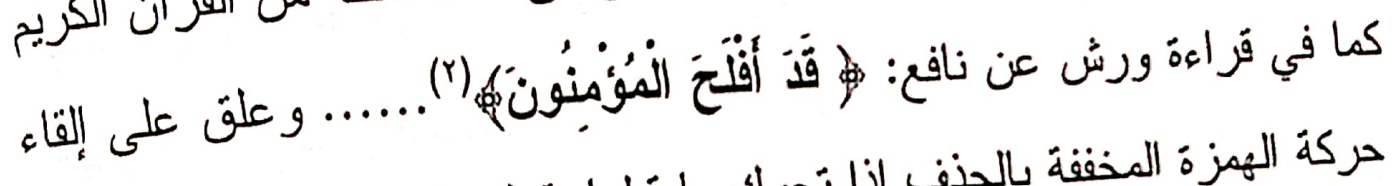

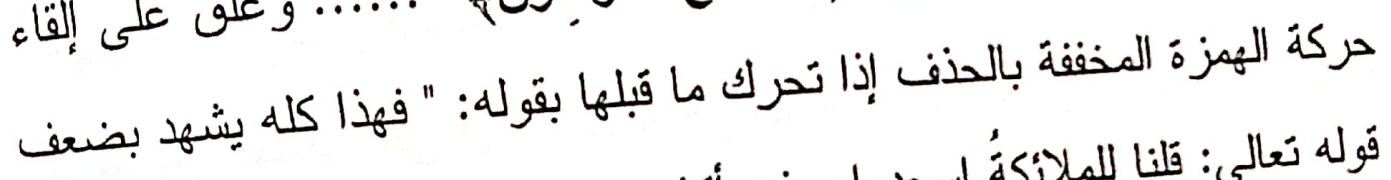

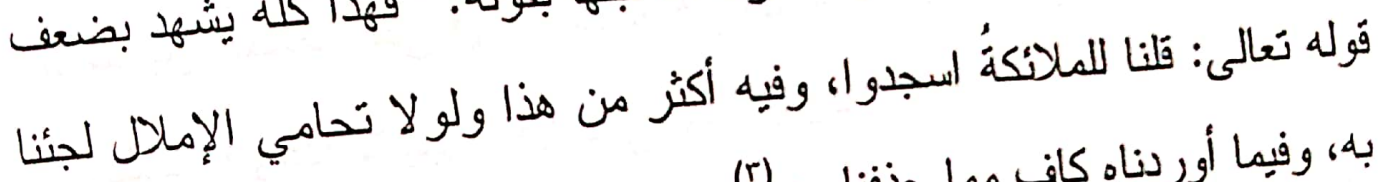

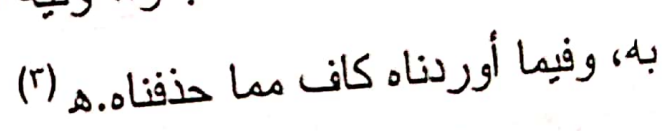

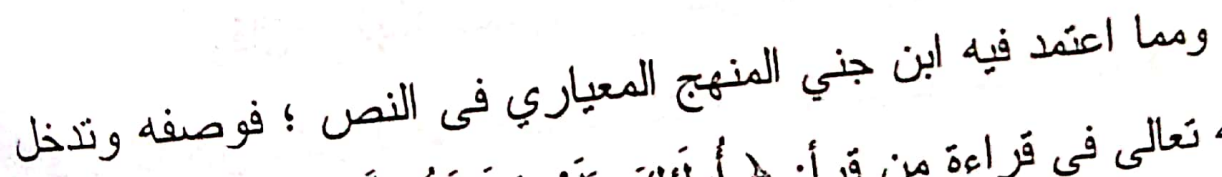

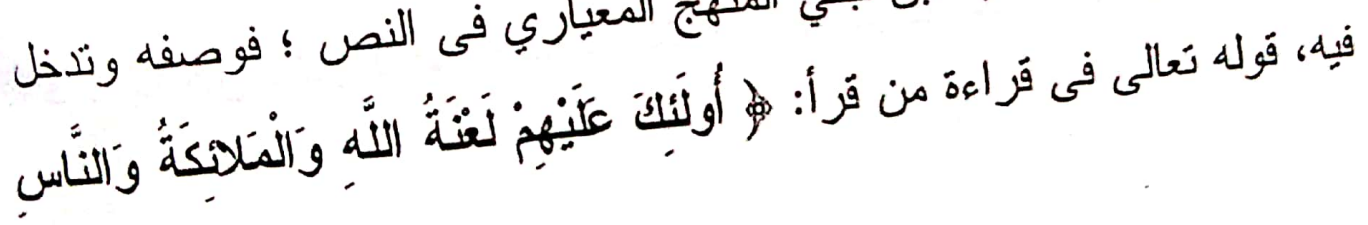

$$
\begin{aligned}
& \text { راجع: المحتسب VY/ VY } \\
& \text { سورة المؤمنون: آيَّ (1) (1) } \\
& \text { المحتسب: }
\end{aligned}
$$




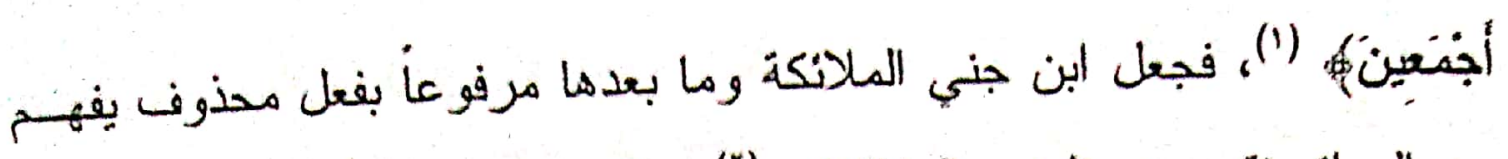
من السياق ثقديره: وتلعنهم الملانكة...(r) وهذا تذخل فى النص لخدمته. ودلسل على ذلك بقول الشاعر : (r)

\section{تذكرَتُ أرضاً بها أهلها}

فنصب الأخوال والأعمام بفعل محذوفت دل عليه المذكور ، ونقديره:

$$
\text { (؛) تذكرت أخو الها..... }
$$

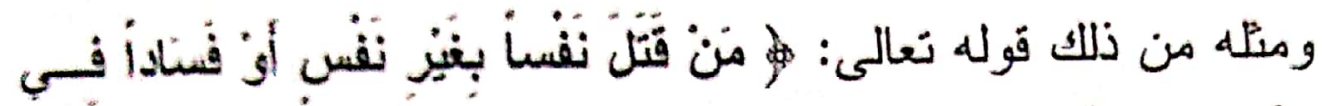

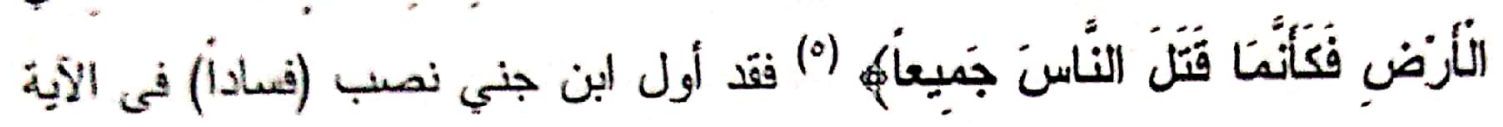
الكريمة بما يدفع عنها شائبة اللحن، ويجعلها تحت مظلة العرن اللنوب المثبول، معنمداً فى ذلك على السياق.

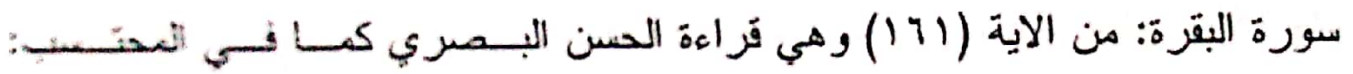

$$
\text { | }
$$

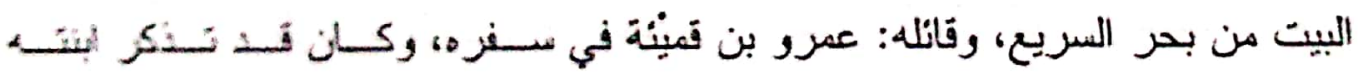

$$
\text { في سفره. }
$$

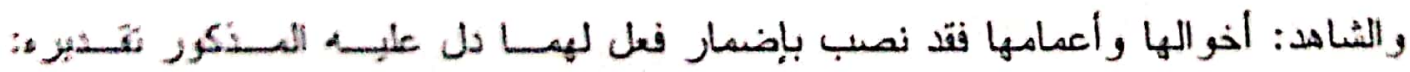

$$
\text { تذكرت، وإما على البدل من الأرض. }
$$

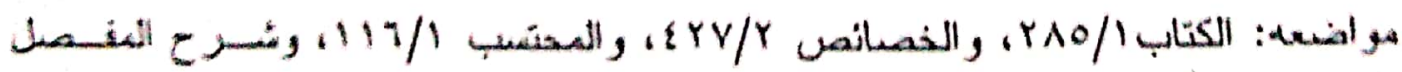

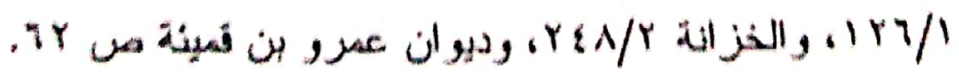

$$
\text { المراجيع التى ذيكرت الثاهد. }
$$

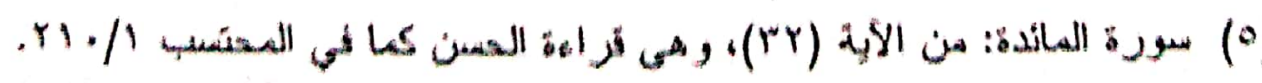

$$
\text { oVV }
$$




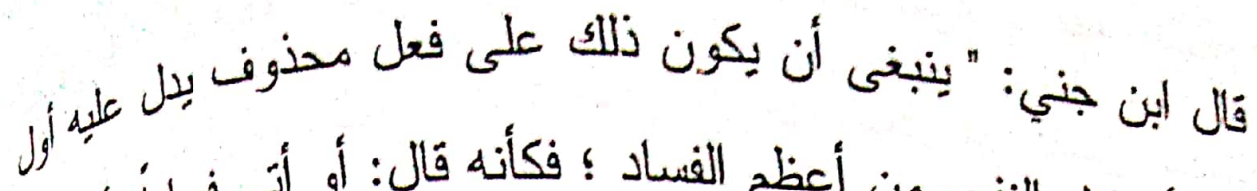

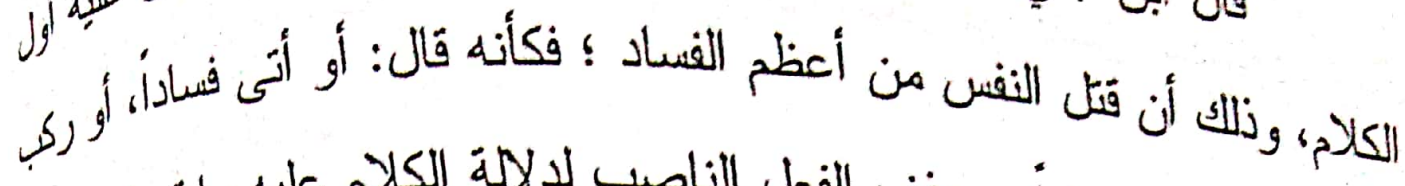

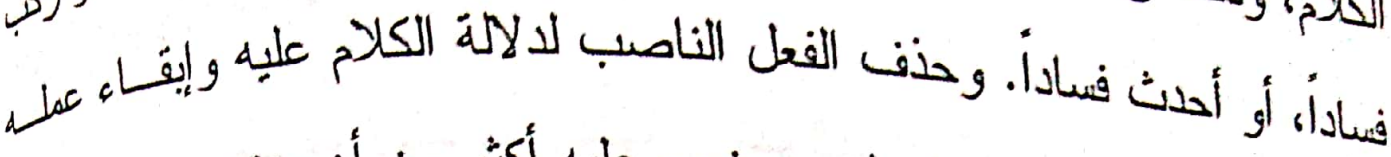
ناطقاً به ودليلأ عليه مع ما يدل من غيره عليه أكثر من أن يؤتى بشّئ منه مر

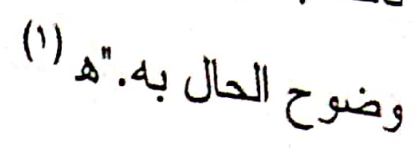

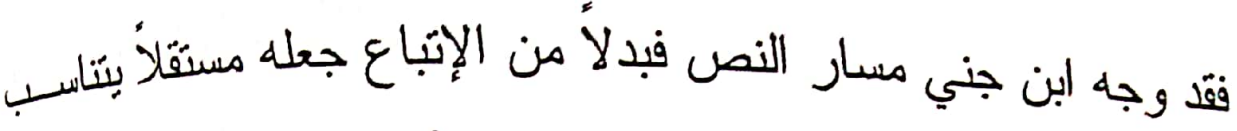
مع السياق ؛ لأن قتل النفس غير إيتيان الفساد ؛ فمن أفسد فى الأرض بأي ألوان الفساد فكأنه تتل النفس ؛ فلذلك نصب فساداً، و أضمر له فعلأ لما يأتي: • أن الفساد معنى و النفس ذات فلذلك لا يصلح لهمـا فهـل واحسـ؛ فالنفس يصلح لها الفعل قتل أن يقع عليها، أو ثقوم به، أما الفسناد فلا بصلح له الفعل قَتل أن يقع عليه ؛ لأنه معنى و المعانى نـؤئتى

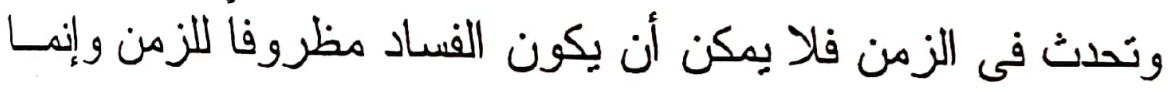
الزمن ظرف له.

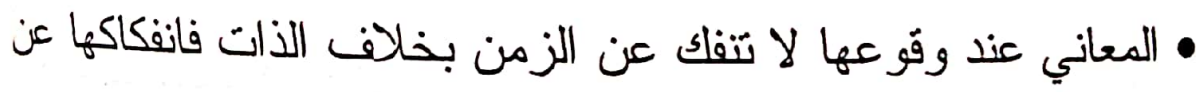

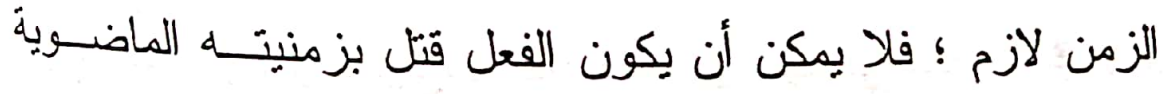

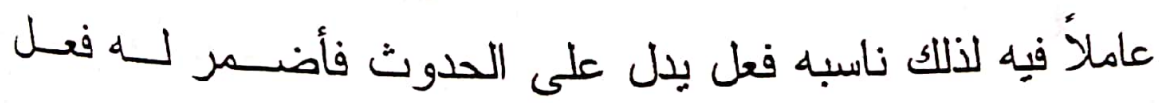
تقدير ه: أتى.... كما ذكر ابن جني.

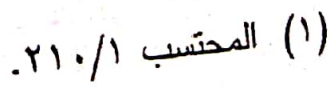


• أن (فساداً) لا يمكن أن يكون عطفه على (بنفس) لأنه ذات والذوات

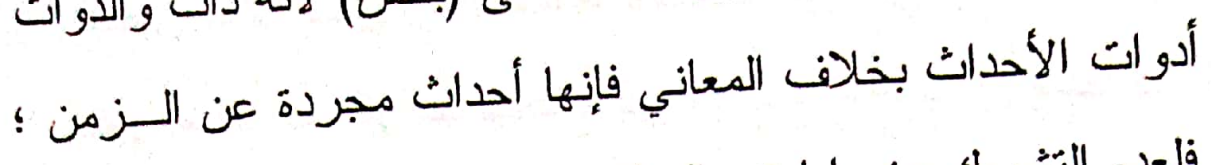

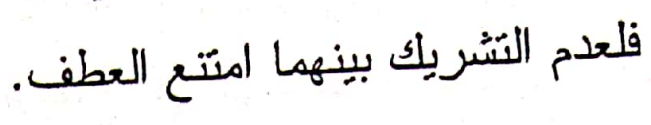

اختلاف جهتي الفعل أو الحدث حالت دون الإتباع ؛ فالقتل: إزهاق

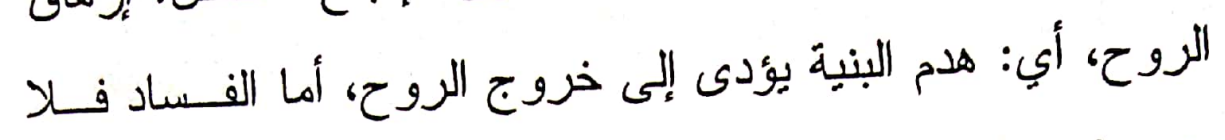

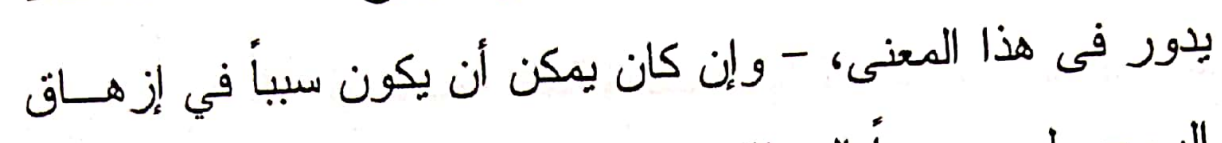

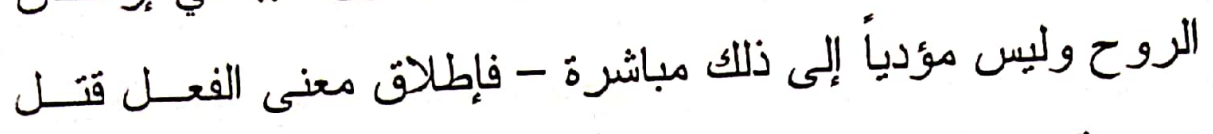

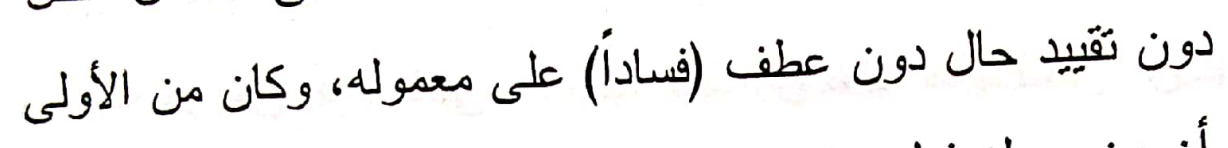
أن يضمر له فعل حتى يؤدى المعنى المراد على أكمل وجه، وهذا

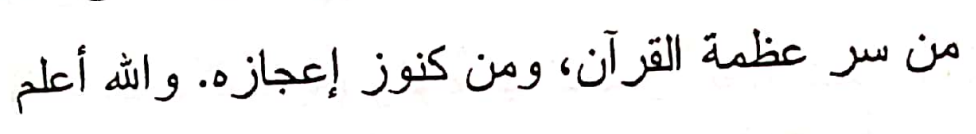

فما ذكرته من نماذج يدل على أن ابن جني - وهو أحد النحاة ـ قد

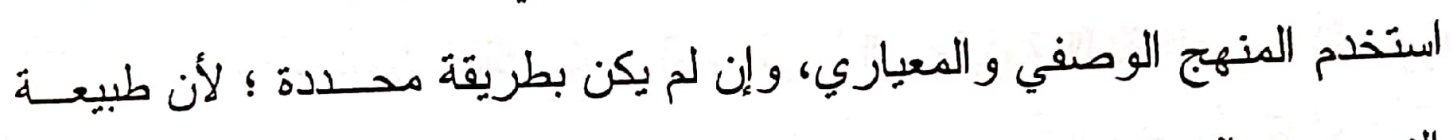

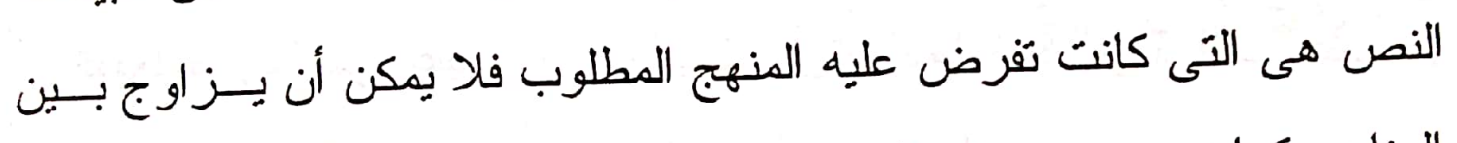

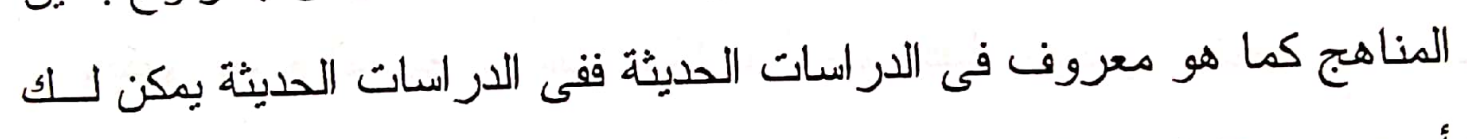

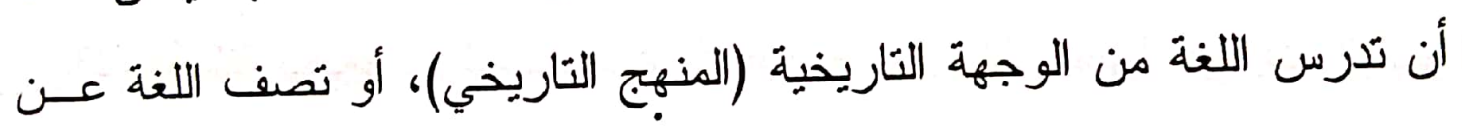

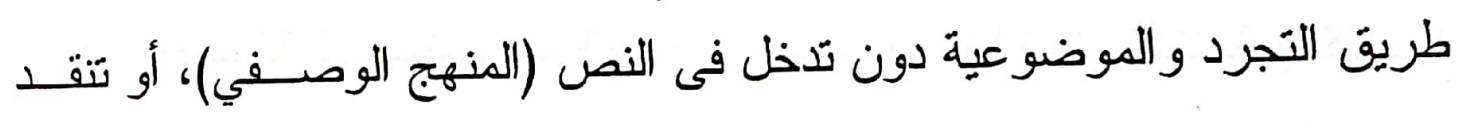
النص وتفرض عليه ما يجب أن يقال، وما لا يجب (المنهج المعياري). و الفرق بينهما أن الأو ائل يدرسوا النص ويتركوا لطبيعتـــه أن تحـدد المنهج المطلوب ـ وصفي أو تاريخي أو معياري - أما فى الدراسات الحديثة

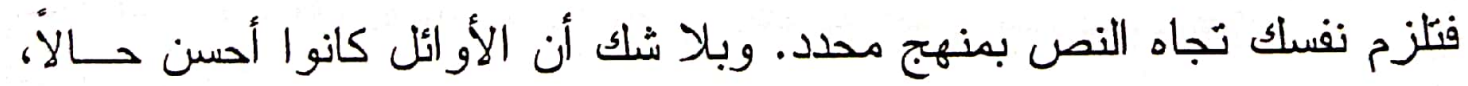


فيقهون أماد النص واحتياجاته، فالحاجة هي التي تحدد المسار ؛ لأن النص فـد يكون منفقاً هع القو اعد فيحتاج إلى وصف، وقد يكون منفقاً فى شئ من جزئنان القاعدة ومخالفأ فى الأخر، فيحتاج إلى الوصف و المعيارية و التّاريخية، وذلسك

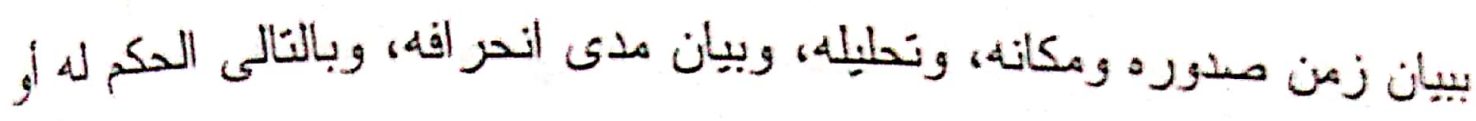
مئ.

كما أن طبيعة اللغةَ ونصوصها لا تتفق مع التوحد المنهجي حبــث إن

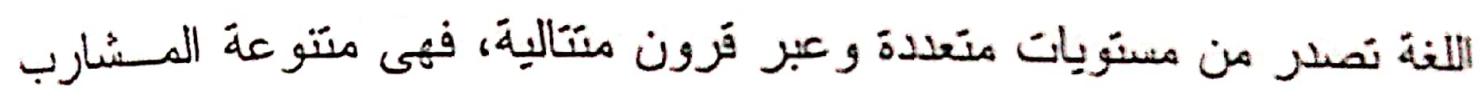

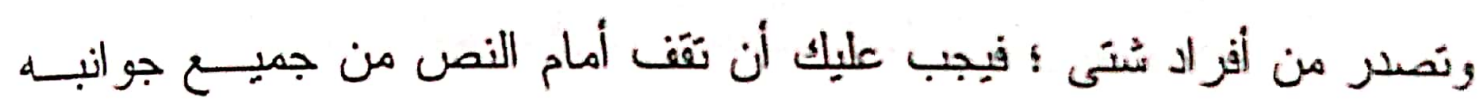

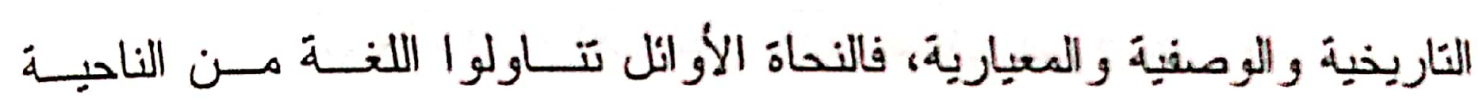
التاريخية (الزمانية و المكانية) و الوصفية فحددوا مسنوياتها ووصفو ها، وحكموا على النص.

والمدنُون كنلك لكنهم لم ينظروا إلى طبيعة اللغة العربية بمستوياتها

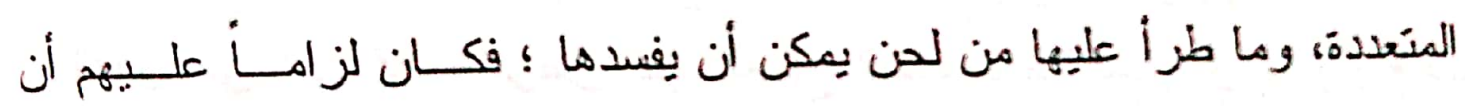

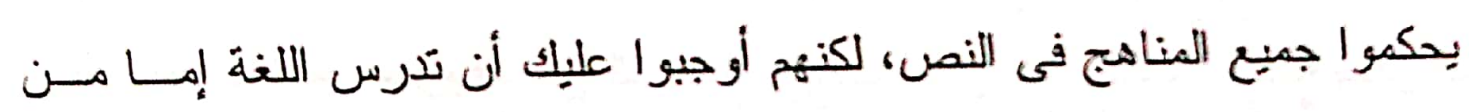

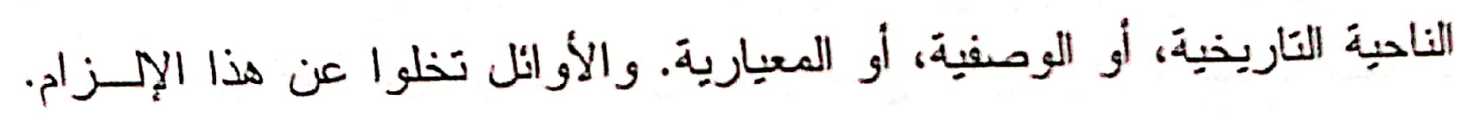

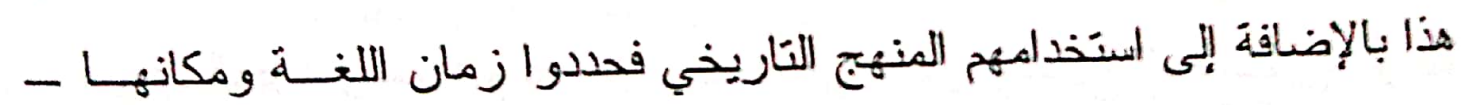

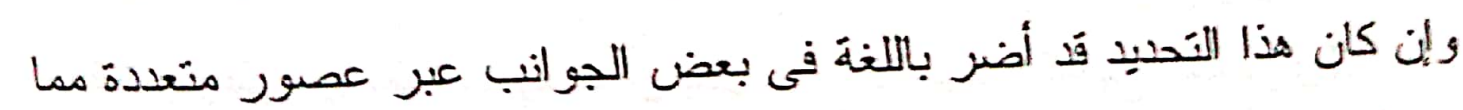

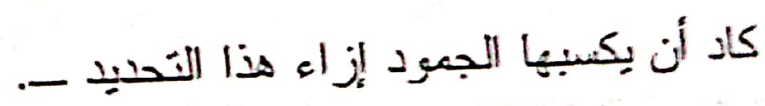

os. 


\section{آليات التأويل النحوي}

\section{الآلية الأولى: الثنائية (قَانون الثنائية)}

ونعنى بها: ما يبنى على العلاقة التلازمية بين الشئ وضده، و البحهـن

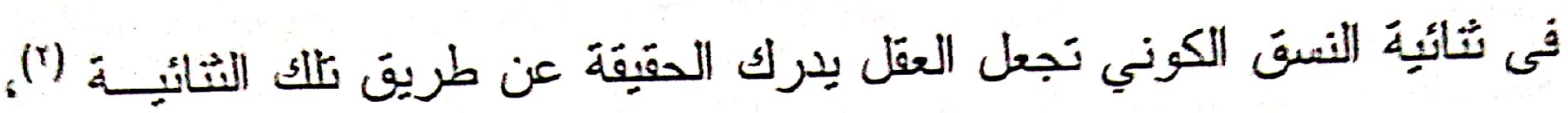

هذه الآليات يمكن أن تلحظعا من خلال تتاول ابن جني لظاهزة التأويل - هذا بالإضافية

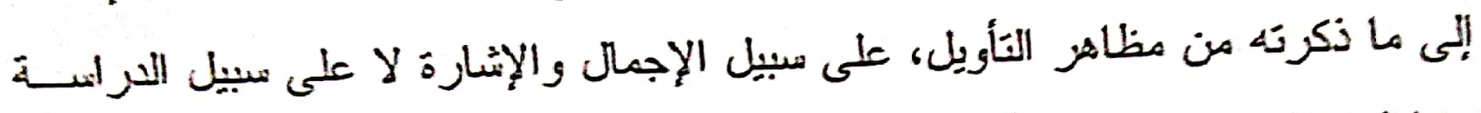

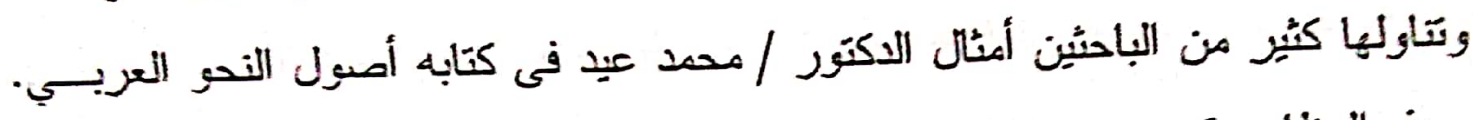

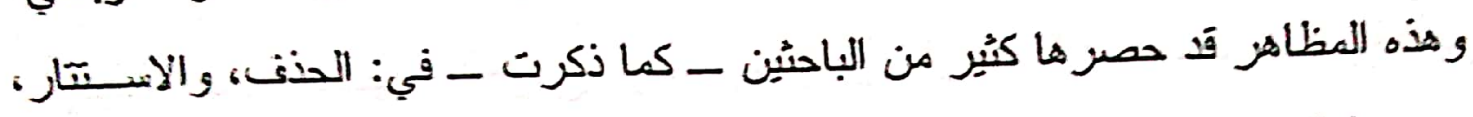

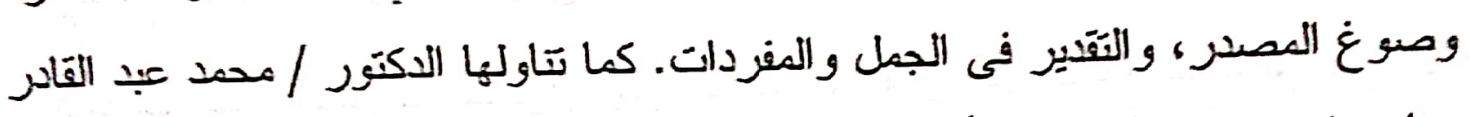

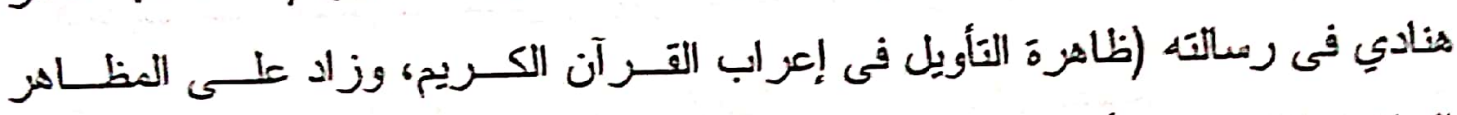

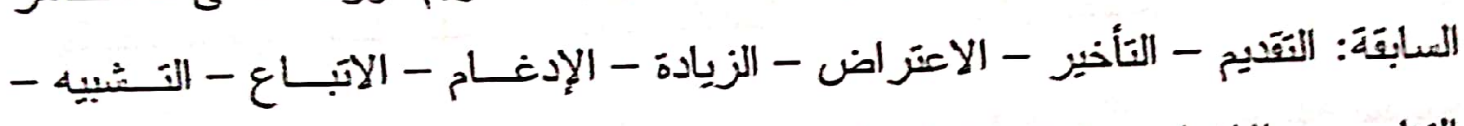

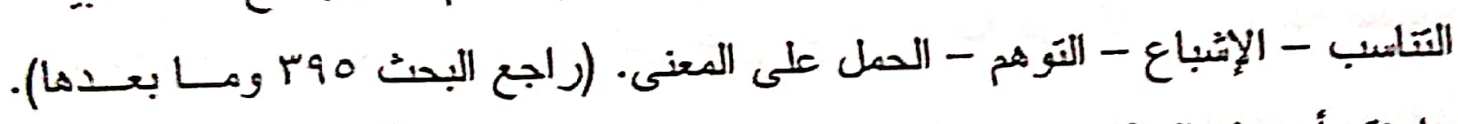

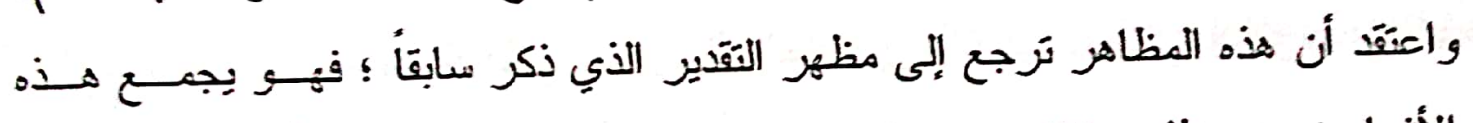

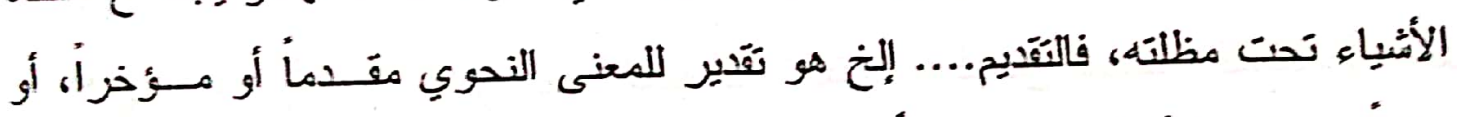
زائذأ.... فهذه الأشياء تعد تفصيلاً بعد إجمال.

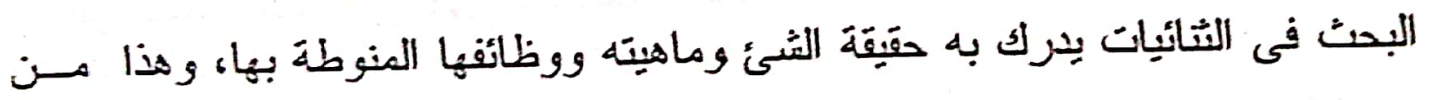

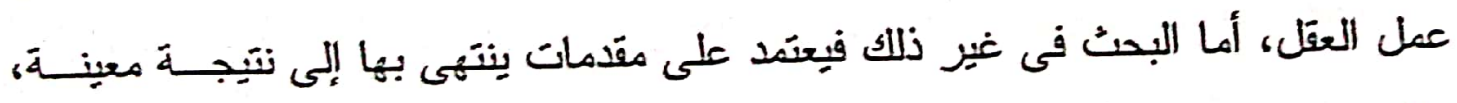

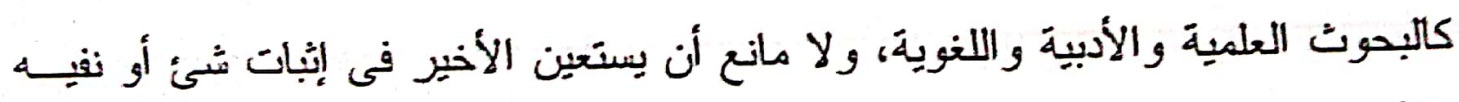

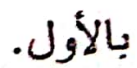

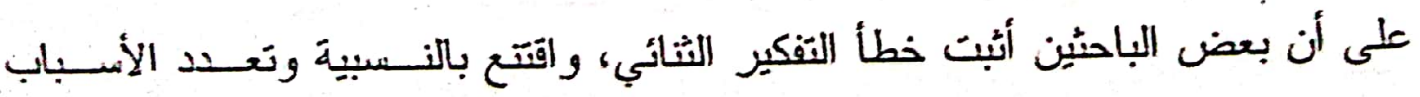

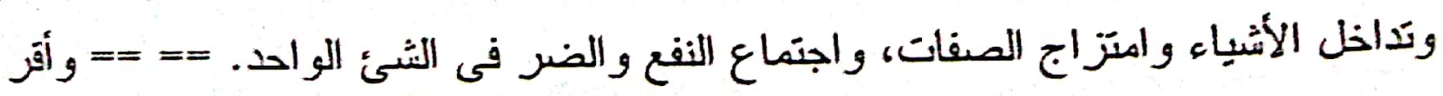

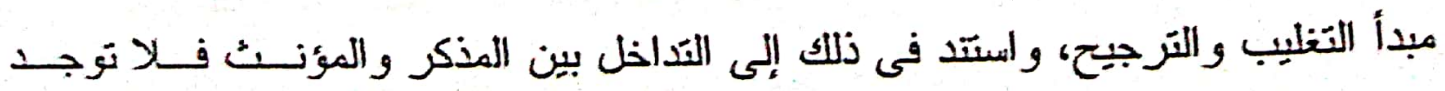

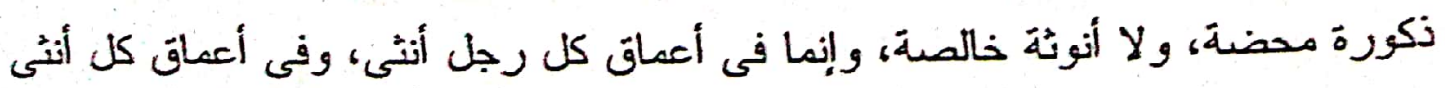


كالحضور و الغياب، والإفر اد والجمع، و الذكورة و الأنوثة....إلخ. وقَ لاحظه. أن ابن جني قد استند فى بعض تأويلاته على هذا القانون ؛ فغلب المعنى النووي المخالف إذا ورد فى نص مخالف للقو اعد على الوجه الذي بنيت عليه الثاعدة ؛ وذللك لما بينهما من التلازم - كما سأوضح - وليس ذلك هدمأ للقاعدة، وإنها. يعنى أن ذلك النص (القائل) غلَّب هذا المعنى على الذي بنيت عليــهـ القاعدة ؛

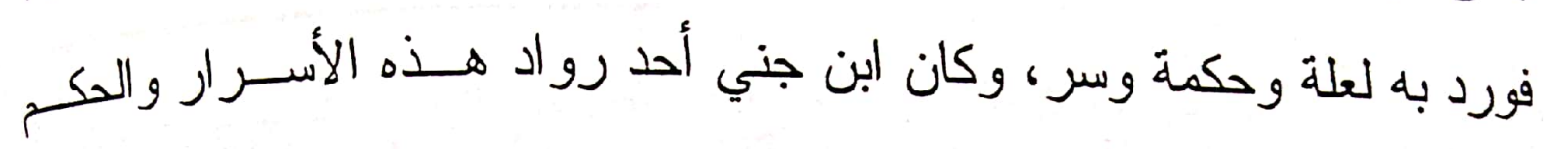
و العلل.

وقد استغل ابن جني هذه الآلية (الثائية) فى مفردات معبنــة، ومعسان وثيقة الصلة بطبيعة العربي، وبما يمكن أن تفرزه المستويات اللغوية العربيسة، فاعتمد على السلوك التأثري بين الثائيات، وأن كل ثنائية قد تؤثر فى الأخــرى فتأخذ هذه ما عند تلك ؛ وبذلك يتذاخلان فى الشكل الظاهري و إن كانتـا لهيـا استقالية وجودية، وقد حقق ابن جني مبدأ الثنائية فى اللغة العربية بصفة عامة، و النحو بصفة خاصة على أساس التذاخل بين الثنائيات التى إذا وجدت إحـــاهـا

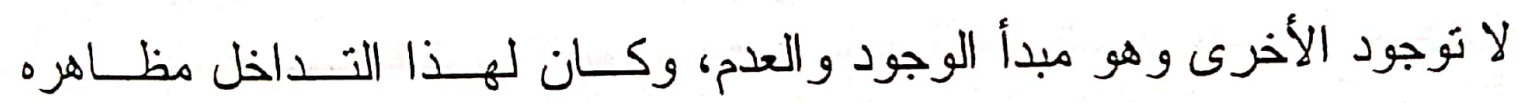

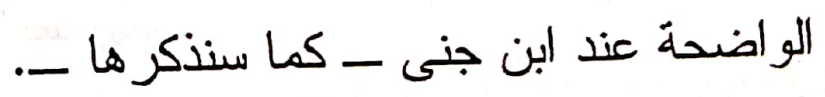

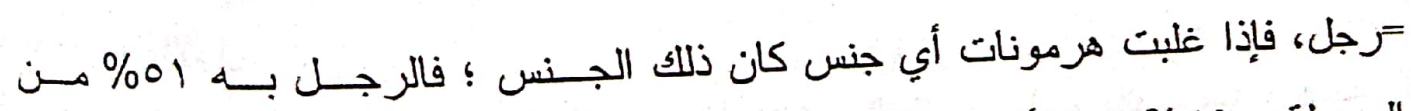

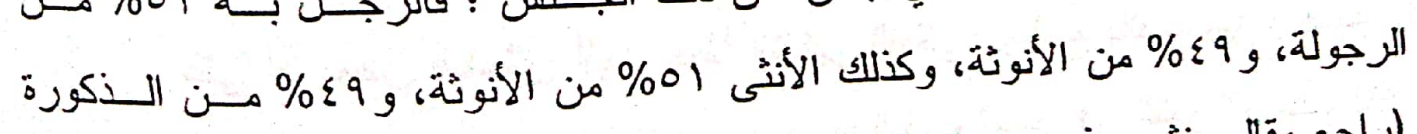

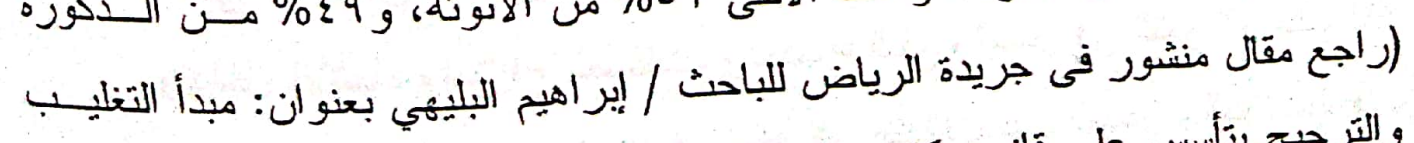

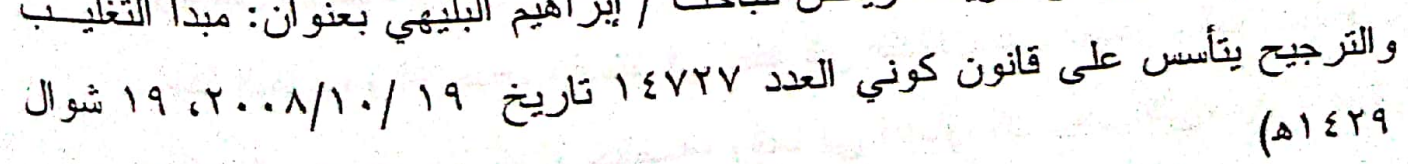




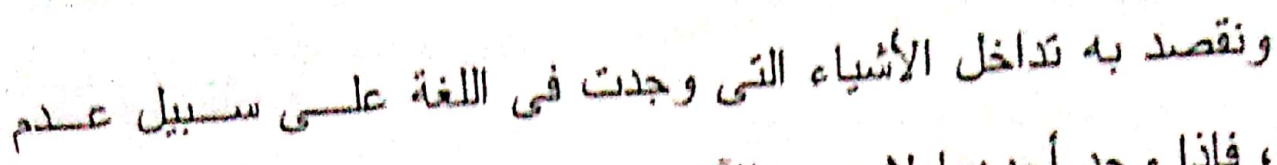

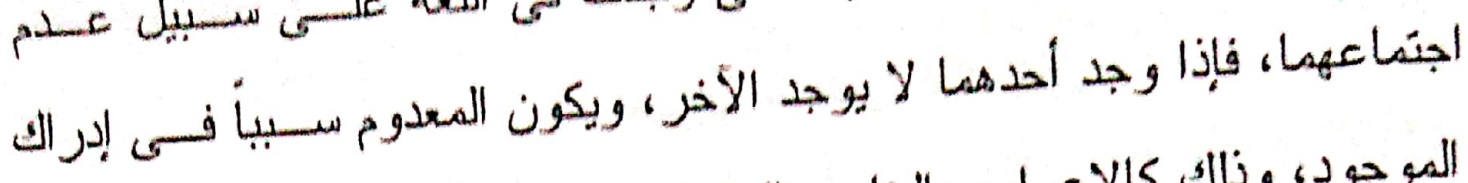

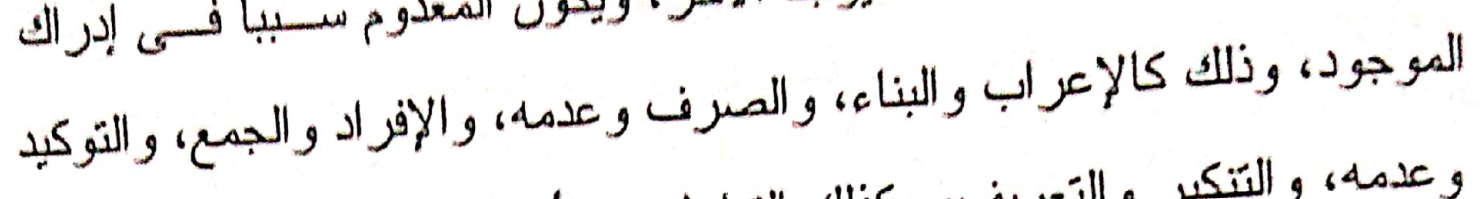

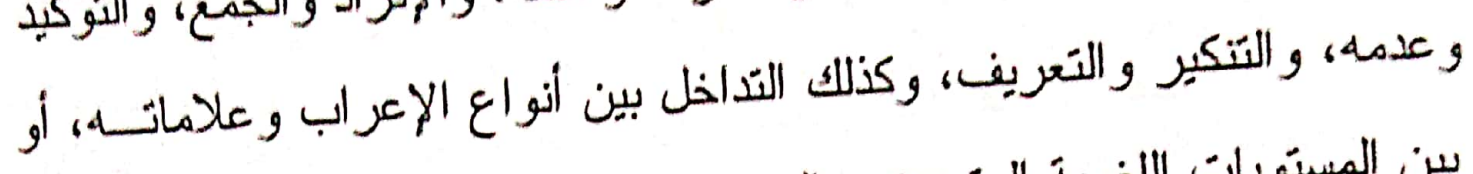
بين المسنويات اللغوية المنعددة... إلخ

فاسنطاع ابن جني أن يؤول بعض النصوص متنمداً على هذه الثنائية،

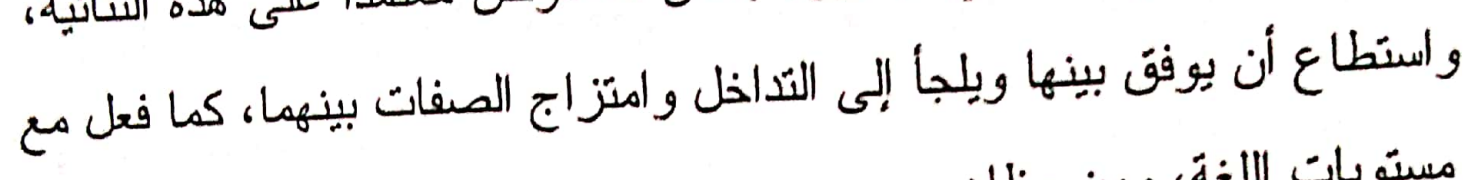
مستوبات اللغة، ومن مظاهر ه:

من المعروف أن الحركة فوق الحرف إما أن نكــون حركـــة أوجـــــا العامل أو المعنى النحوي - على خلاف - و إما أن تكون حركة حرف المبني، ولكل موضعه ؛ فحركة الإعراب تكون آخر الكلمة فى الحرف الأخير منهـا، وحركة حرف المبنى تكون فوف الحرف فى بنية الكلمة.

ولكن عندما تنجاور الحركتان وتظغى إحداهما على الأخرى فيتذاخلان فتحلب إحداهما الأخرى فى وجودها، وهذا الأمر ليس على سبيل الاطر اد، ولكن

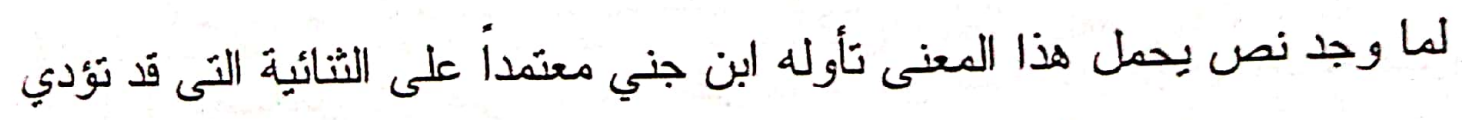

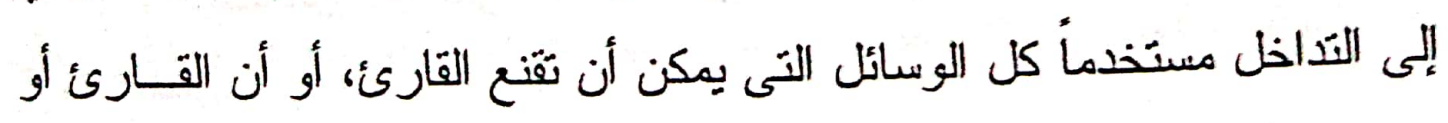

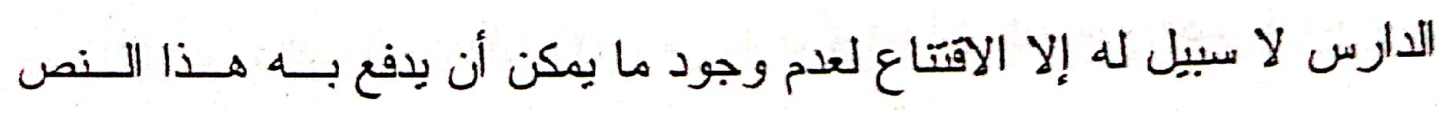




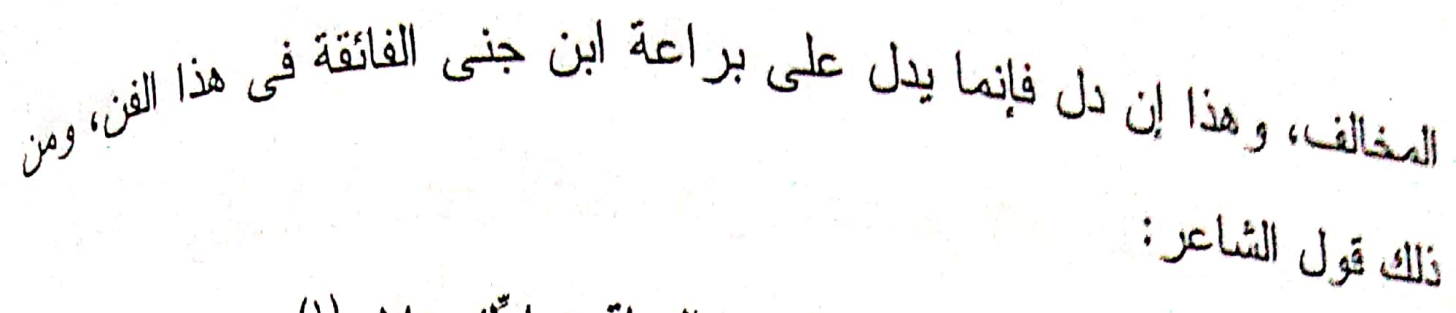

وقال اضرِب الساقين إِّكّ هابل (1)

قال ابن جنىى: "وقد دعاهم إيثـار قَـرب الــصوت إلــى أن أخلــوا بالإعراب، فقال بعضهم: وقال اضرب الساقين أمك هابل. " هـ (r) وقل ذكره ابن جني فى التقريب بين الأصو ات فقرب الأصوات بجلها

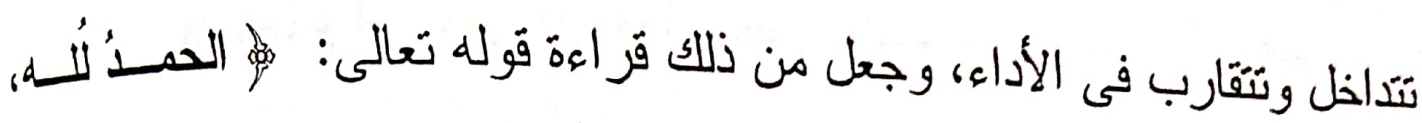
والحمد لله به (r) وبحث ابن جني فى سر التداخل بين الثائيات فوجد أن التــداخل فــــ حدث بين الأصوات فى الكلمة الواحدة أو الكلمنين، وقد أرجع السر فى ذلك إلى إلى

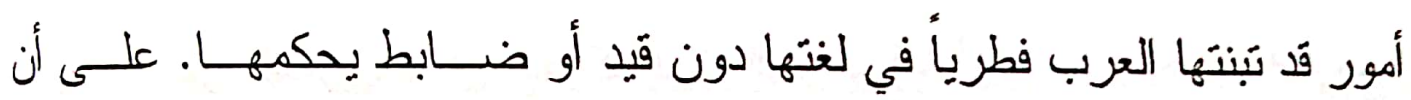

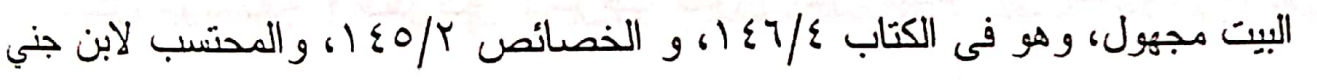

$$
\text { الفا }
$$

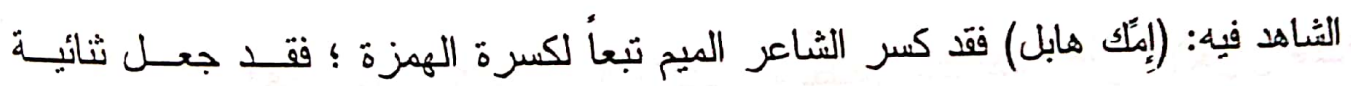

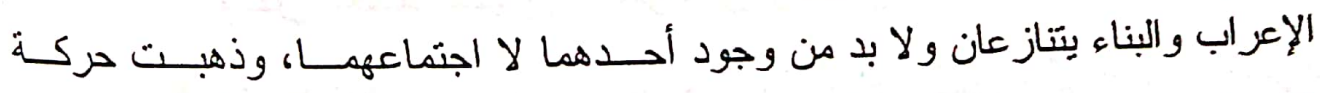

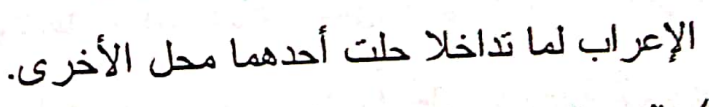

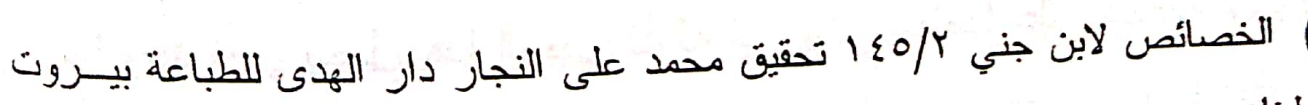
كبنان.

(T) سورة الفاتحة: من الآيذة (Y)، وهى بالرفع قراءة أهل البادية، وبالكسر قراءة إبـر اهيخ

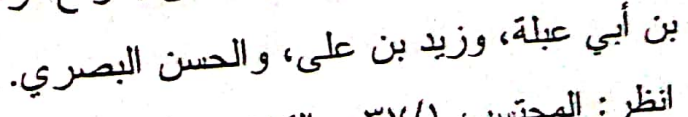

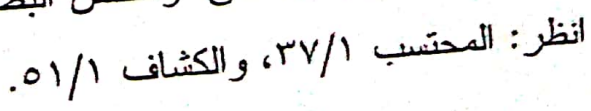




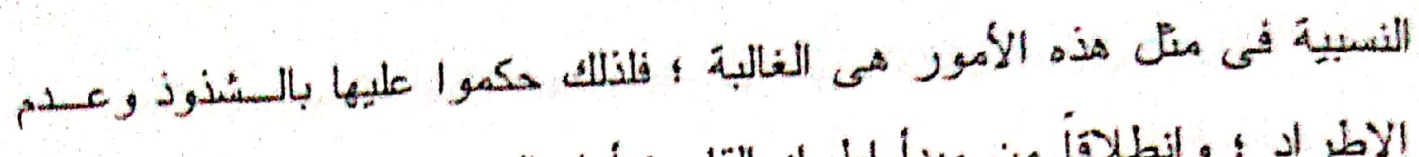

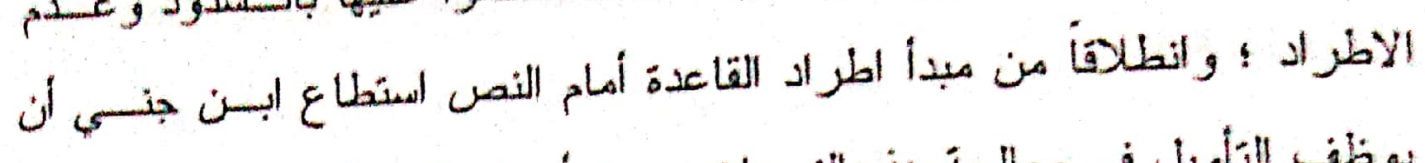
يوظف التأويل فى هبالجة هذه النسبيات، ومن أسرار النداخل عنده:

(1) كثرة الانستعمال، فقد أرجع المر فى نص قراعة الحمد لله بالضم و الكسـر إلى كثرة الانستعمال، فقال: " إن هذا اللفظ كثر فى كلامهم، وشاع استعماله،

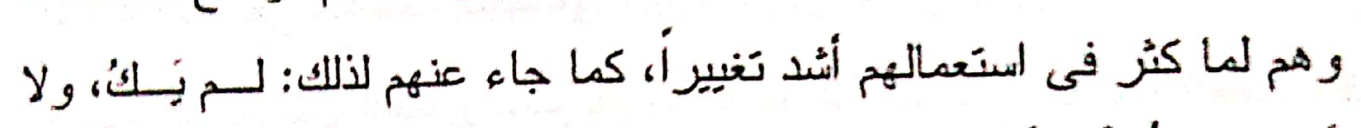

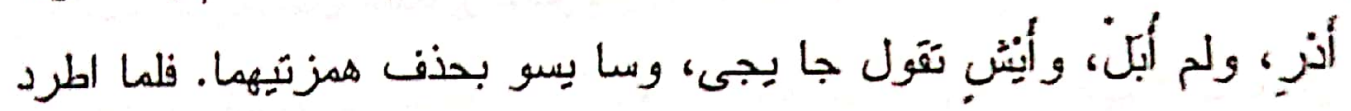
هذا ونحوه لكثرة استعماله أتبعوا أحد الصوتين الآخر، وشبهو هما بـالجزء الو احد وإن كانا جملة من مبتدأ وخبر، فصارت (الحمد اله) كُنُق وطُّـب (و الحمد .لله) كايِل وإِطل. إلا أن الحمد لله بضم الحرفين أسهل من الحمـــ

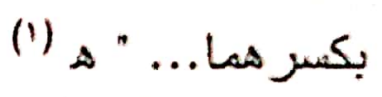

(Y) شدة النتلازم و الاتصـال، فقوله: الحمد الله جملة من مبتدأ وخبر، فقـــ شـبـ الجز أين معأ (المبندأ و الخبر) بالجزء الواحد ؛ فكأنهما كلمة واحدة مثل: مُُّ

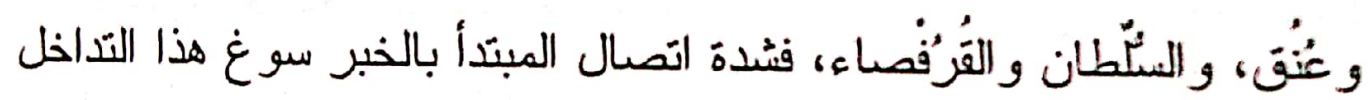
بينهما فى الحركات، ومما يذل على شدة الاتصال بينهما أنــك إذا سـميت بنحو: زيد أخوك، فنسبت إليه قلت: زيدي بحذف الجزء الثاني من الكلمة ؛ وذلك إن دل فإنما يدل على أنهما كلمة واحدة أو فى حكمها، ويأخذان حكم

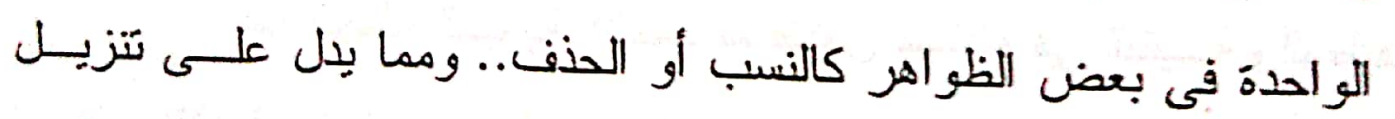
المبندأ والخبز منزلة الجزء الواحد حكاية الفزاء، وهو أنه جرى ذكر رجل

$$
\text { المحتسب لابن جني rv/ }
$$

010 


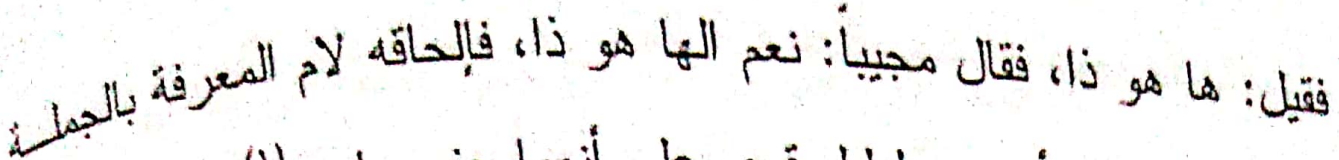

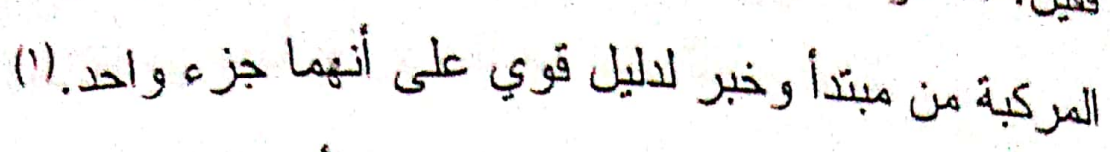

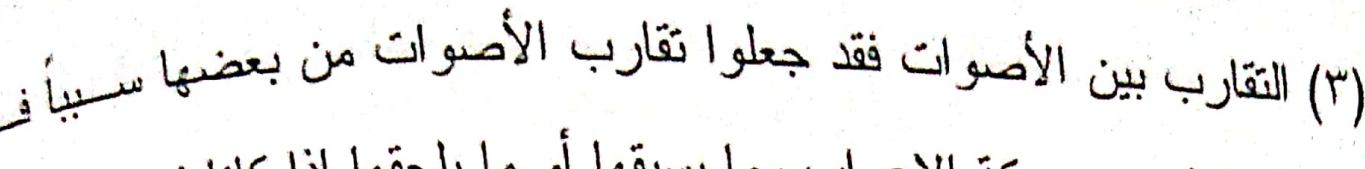

التداخل بين حركة الإعراب وما يسبقها أو ما يلحقها إذا كانا في كلمنين.

على أنه مما بلحظ فى هذا الذي قرره ابن جنى أنه استخدم الثنائيَّة التى

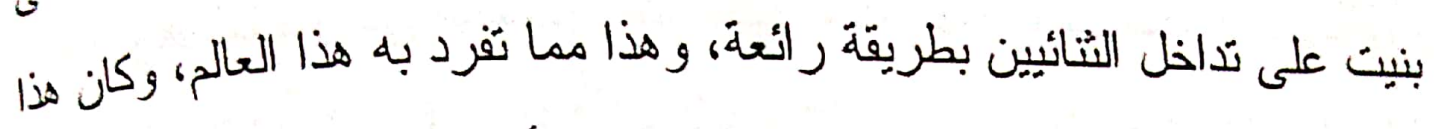

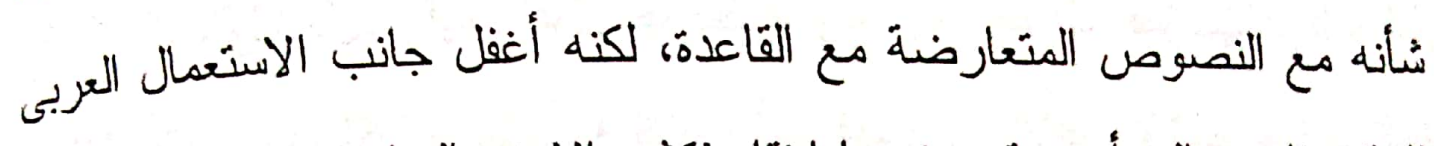

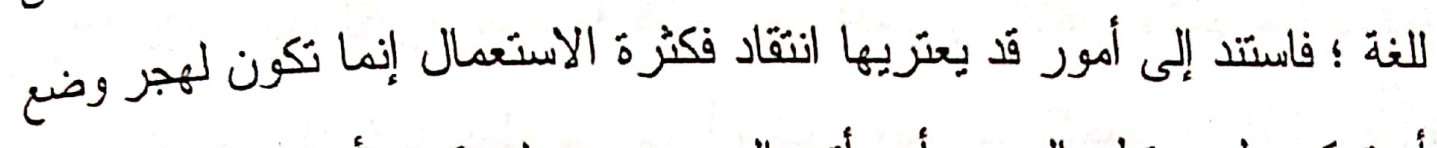
أو تركيب لم بستطع العربي أن يأتيه إلى وضع بديل يكون أحسن منه فى الأداء و الخفة على لسانه.

فما وضع من قو اعد وقو انين فى النحو لا ينبغي أن تهمين وتسبطر

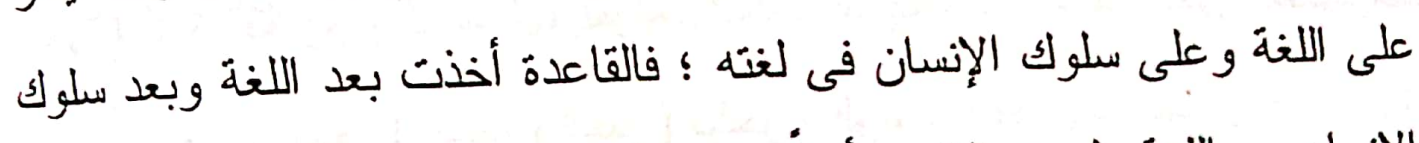

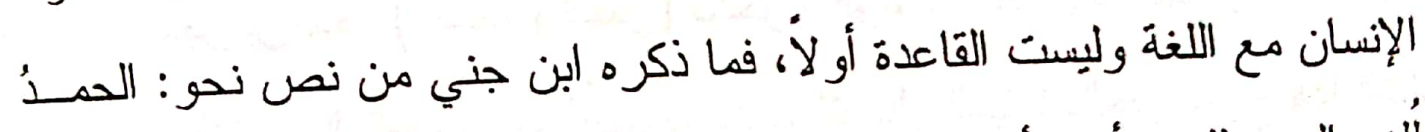

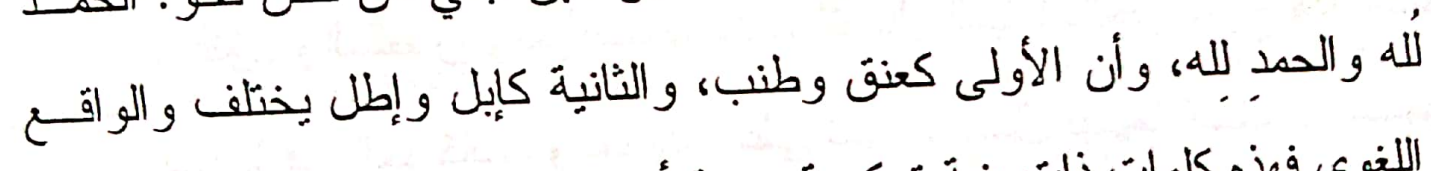

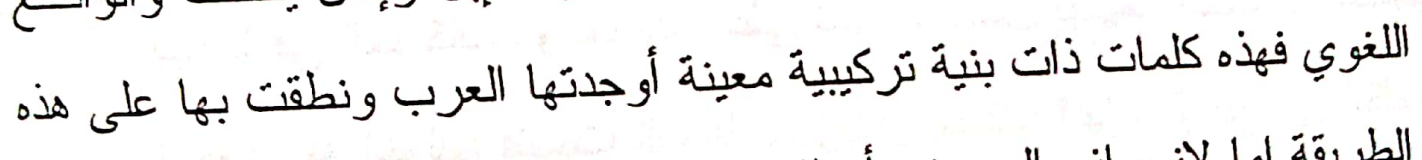
الطريقة إما لإنحر اف الصوت، أو الإندر اف فى الأداء.

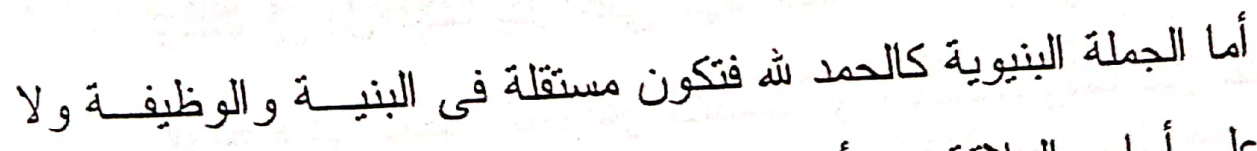

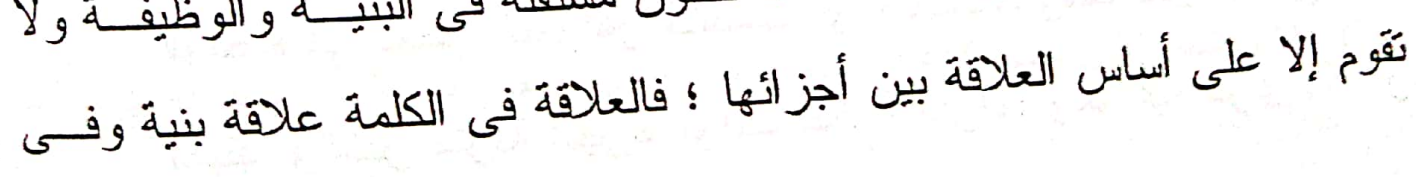


الجملة علاقة معنى ؛ فكثرة الاستعمال لا تكون جامعاً لهذا التاخل فى الأصوات بين الجملة و الكلمة.

و الذى يمكن أن يجمع هذا التاخل بين الأصوات فى الجملة أو الكلمة هو الأداء العزبى، وما يمكن أن يصيب الأداء أثناء القيام بأداء الكلمة أو الجملة.

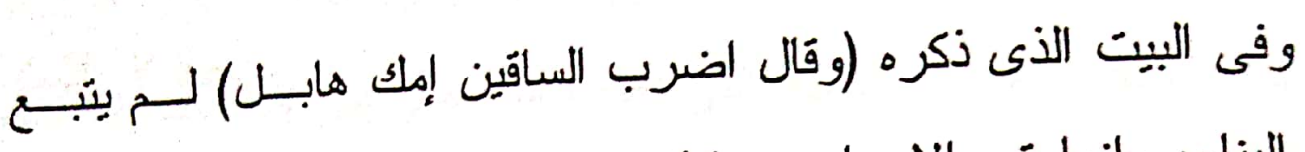
الإعراب البناء، وإنما تبع الإعراب حركة حرف المبنى، فالحركة فى الهمــزة ليست بناء ولا حتى فى النون.

لهذا كان ما قرره ابن جني فى مثل هذا الأهــر مسن الثقــارب بــين الأصوات ولذلك تداخلت على العربي فى النطق هو الأرجح ؛ لأنه يسسلم مسن النقد والاعتز اض ؛ لأن عملية الأداء للصوت تحكم أداءه أعضاء خلقية قد تكون سليمة وقَ تكون غير ذلك، وهذا مما لا يمكن الحكم عليه أو التكهن به لأنـهـ لا يعرف حال العربي حال النطت بأي صوت. واله أعلم. وقَد فرق ابن جني بين إتباع الضم للضـم، وإتباع الكسر للكـسر فــى نحو: الحمد الهه، فذكر أن إتباع ضمة اللام لضمة الدال أقبس وأرجـح مراعــاة للترتبِب الوجودي فى الجملة، كما أن ضمة البال إعراب وكـسرة الــلام بنــاء وحرمة الإعراب أقوى من حرمة البناء...إلخ."(1) 


\section{ثانياً: التداخل بين المستويات اللغوية (1):}

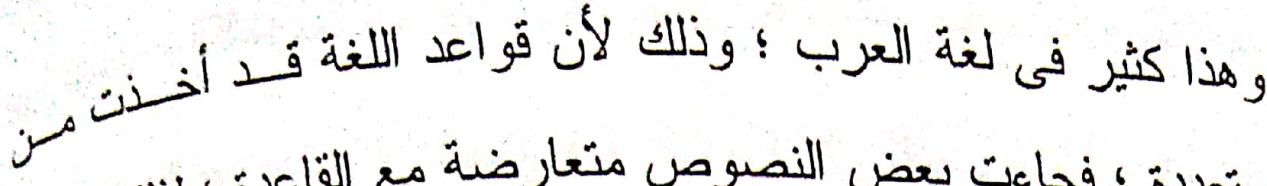

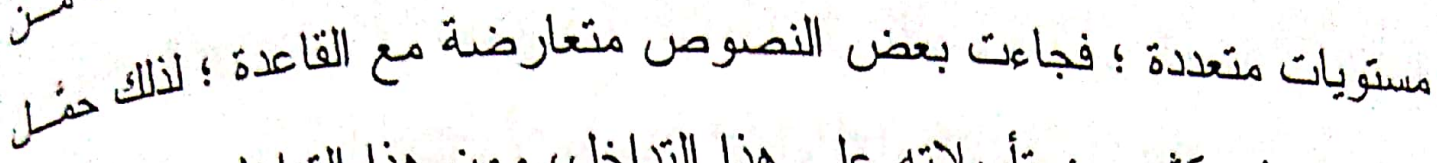
ابن جني فى كثير من تأويلاته على هذا التذاخل، ومن هذا التذاخل - على سبيل المثال لا الحصر -

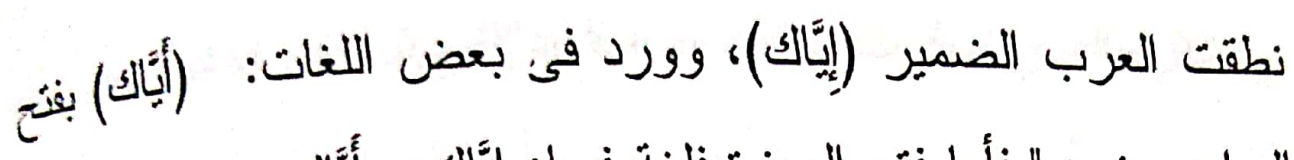

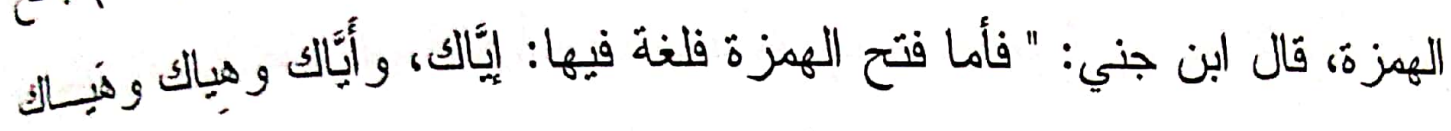

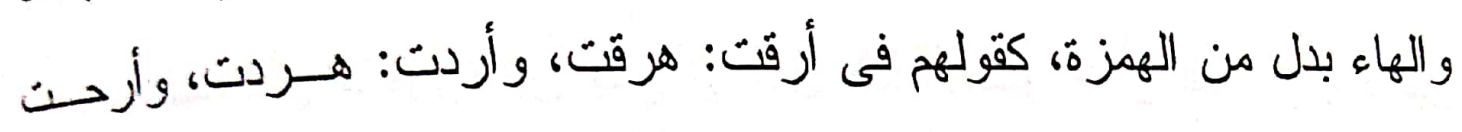

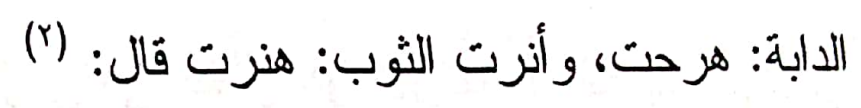

فهياك والأمر الأي إن توسعت موارده ضاقت عليك مصادره " (ז) لقد استخل ابن جني المستويات المنعددة للغنة فى تأويسلـل كثيــر مسن

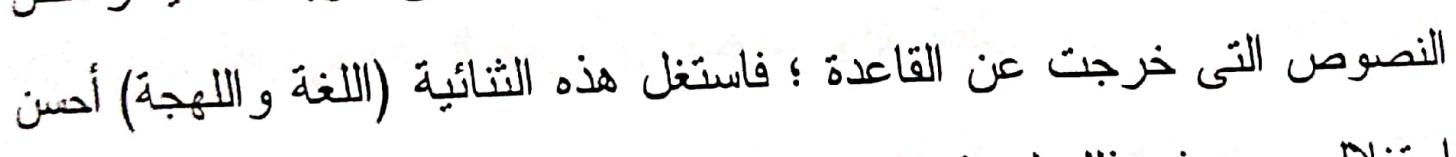
استغله وبر ع فى ذلك لسعة علمه و اطلاعه.

ولكن الغريب الذى يلفت النظر من أول و هلة فى هذا النص أن ابـن

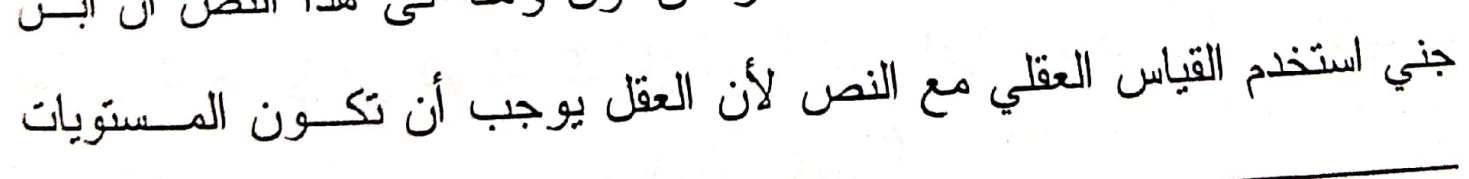

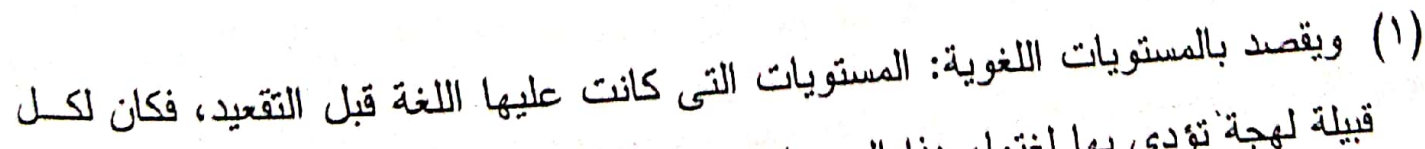

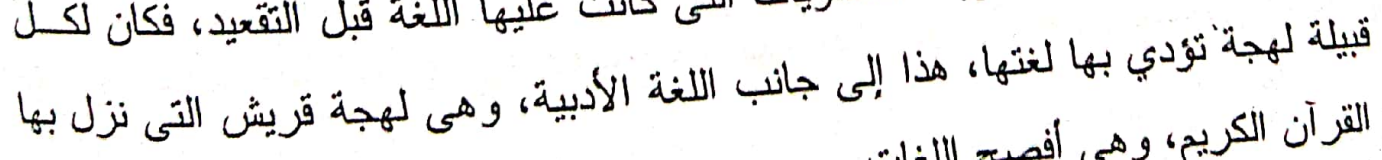
القرآن الكريم، وهى أفصح اللغات.

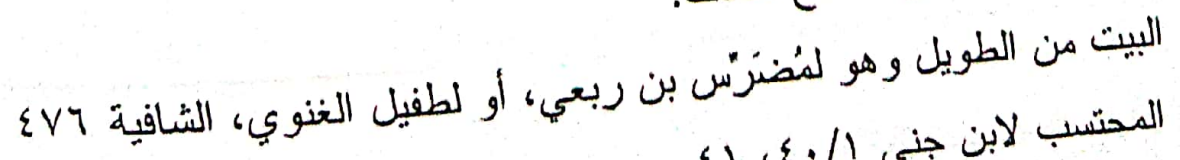


أربعة، واحد لغة (إِّاك)، وو احد لهجة (إِيَّاك)، أما مع الإبدال فلا أن تبدل الهمزة. ويتبعها إبدال فى اللهجة ؛ فهذا أمر عقلي. وولئ

ومن جانب آخر أن اللغةً إياك وإيدال همزتها هـاء وارد فــى لغسـة

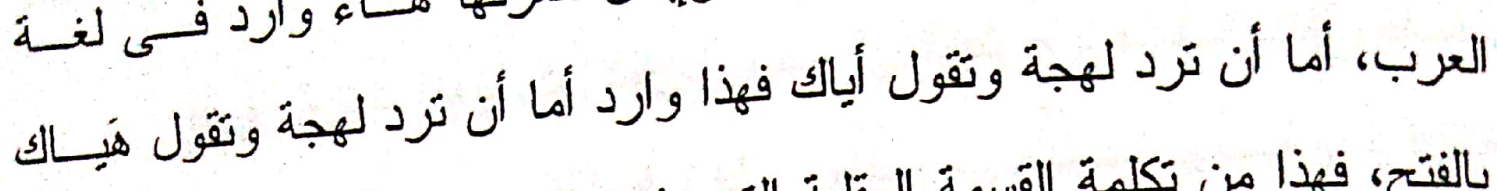

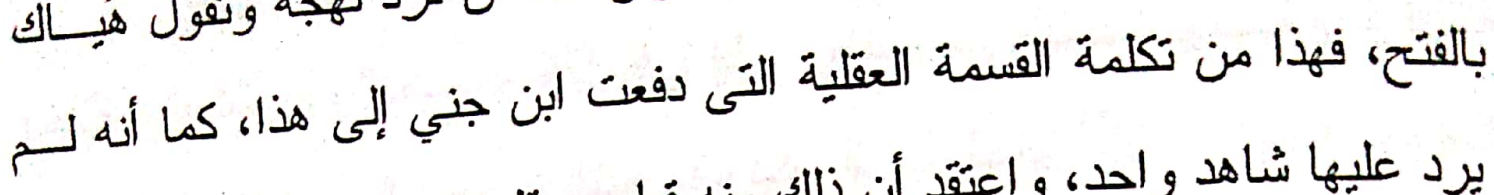
يرد عليها شاهد واحد، واعتقد أن ذلك منه قياس عقلي.

ومن ذلك أيضاً تسكين المتحرك المفتوح ومنه قول الشاعر : (1)

وما كل مبتاع ولو سلفف صفقُه يراجع ما قد فاته بردِداد

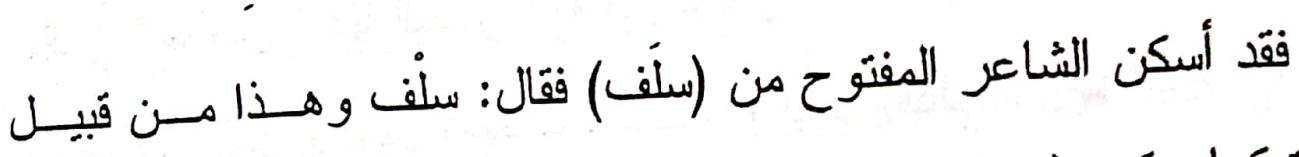

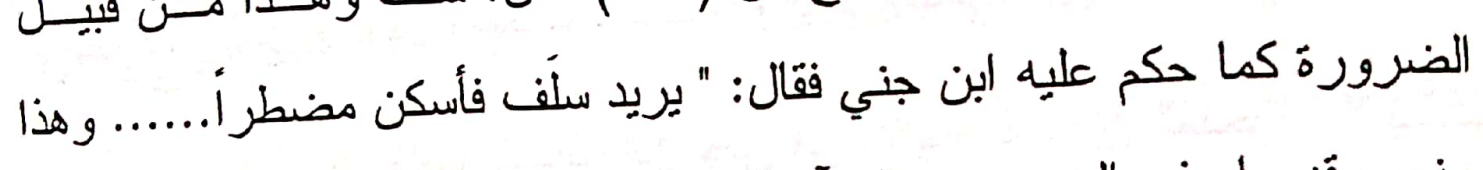

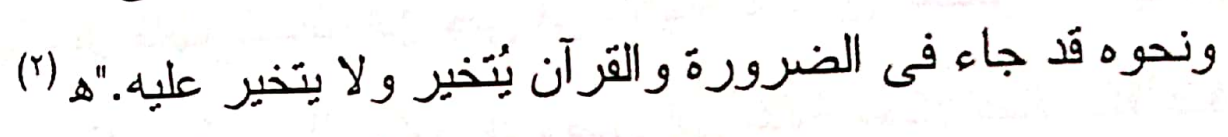

هذا فى الشعر فقد وجد له محملأ يحمل عليه وهو الــضرورة فــاذا

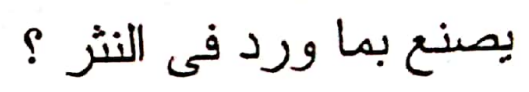

(1) البيت من الطويل، وهو للأخطل، والمبتاع: المشتري، والصفق: مصدر صفق البـائع إذا ضرب بيده على يد صاحبه عند المبايعة، والرداد: مصدر راد البـائع صـاحبه إذا لإنا

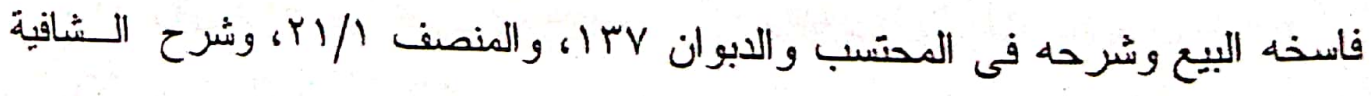

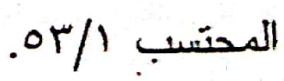


قد لجأ إلى التداخل بين شائيات المستوِيات اللغوية (اللغنة و اللهجة) فذر

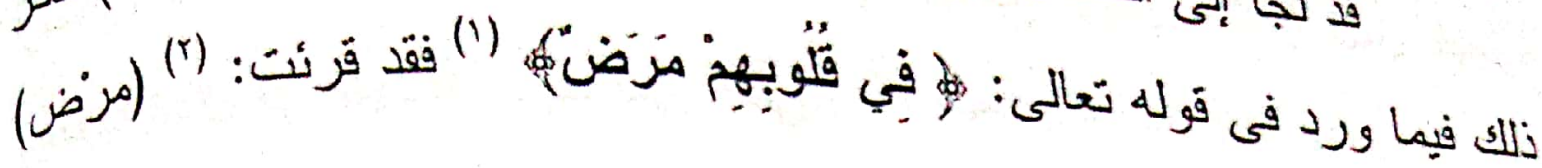
بالسكون.

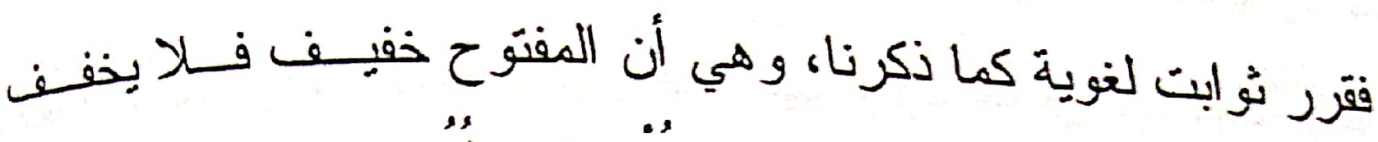

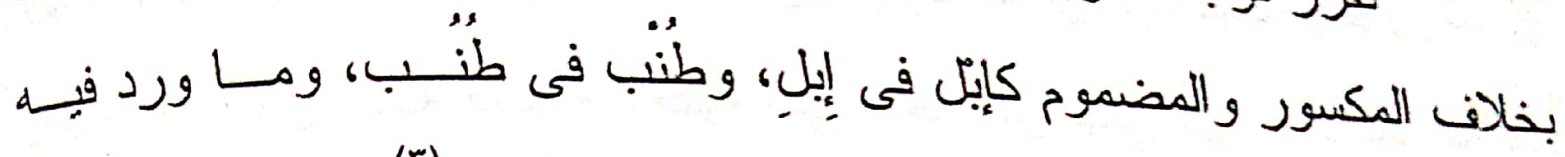
المفتو حخفقاً فبابه الضرورة الشعرية،وذكر البيت السابق (r). ثخ قرر فيما ورد من نص فى تسكين المفتوح أنه لغة على الرغم مسن علم سماع تلك اللفظة عن العرب، و إنما قاسها على غير ها فقال: "وينبغسي أن يكون " مرضض " هذا الساكن لغة فى مرَض المنحرك كالحلب و الحلَب، و الطـــــ

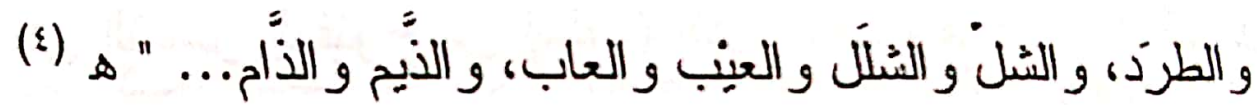

و هذا دليل قاطع يِجله ابن جني فى تأويله، فنتسكين المتحرك لا بـاب له إلا الضرورة الشعربة، وبذللك يكون قد وصل إلى غاية الحكم عملاً بالقاعدة، ثُ فؤجئ بنص نثري قد ورد فيه ما خالف القاعدة فلم بجد أمامه إلا هذه الثنائية (اللغة و اللهجة) فحكم عليه بذلك.

$$
\begin{aligned}
& \text { (1) سورة البقرة: من الآيَة (·) (1) (1) }
\end{aligned}
$$

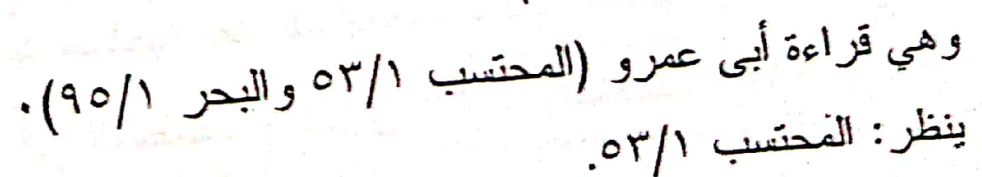

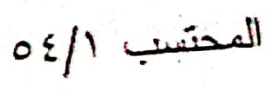


ومما يؤخذ على ابن جني أن مرض فى مرض لم يسمع، وكان حكمه عليه بمستوى لغوي معين مصدره القياس على غيره مما سهع، وهذا لا يستقيم لأن أي مستوى لغوي يؤخذ بالسماع لا بالقياس.

وقد استتد فى هذا الحكم إلى معطبيات لغوية سليمة منها: القياس علــى

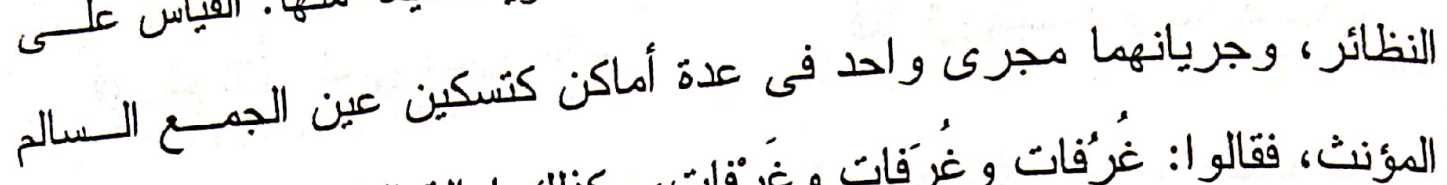

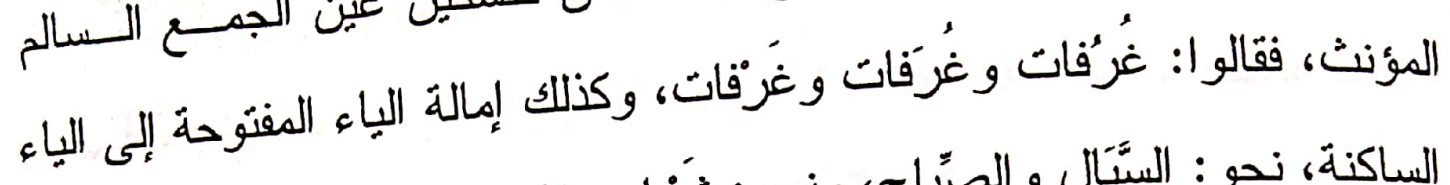

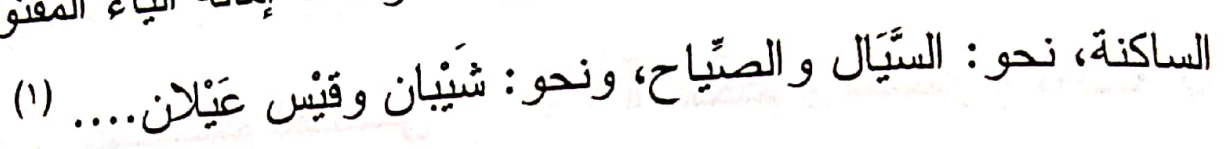
وهذا اللون كثير عند ابن جني كثرة مفرطة، ومن ذلــك قلـب ألـف

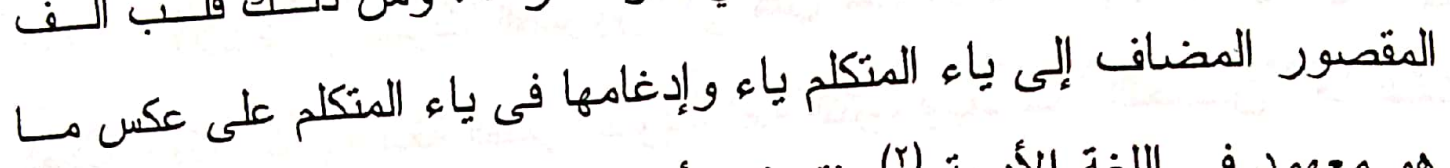

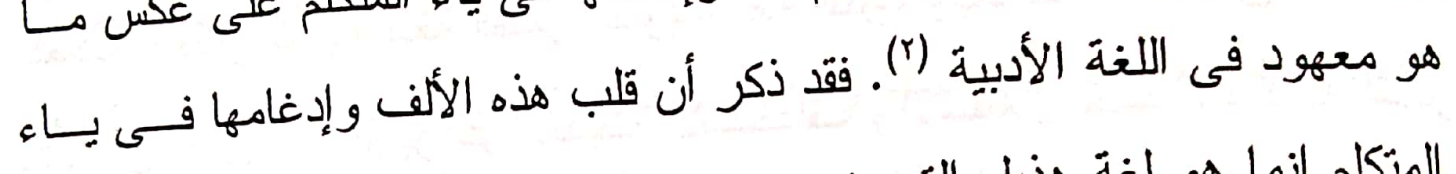

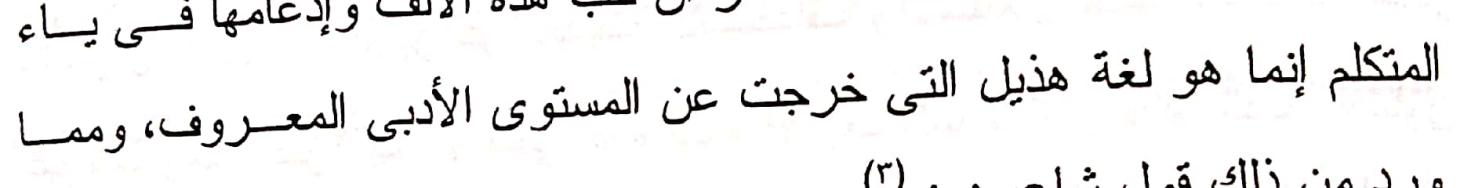
ورد من ذلك قول شاعر هم: (r)

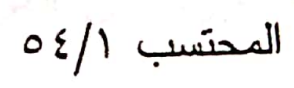

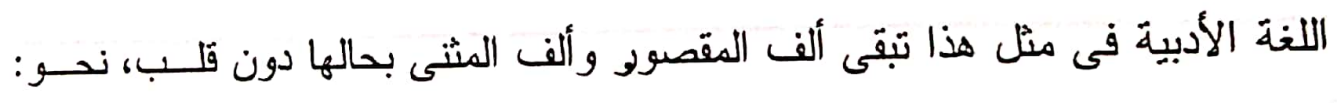

مسلماي، و هداي، وفتاي، وقد ورد فى لغة هذيل قلب الألف فى المقصور عوضاً عـن

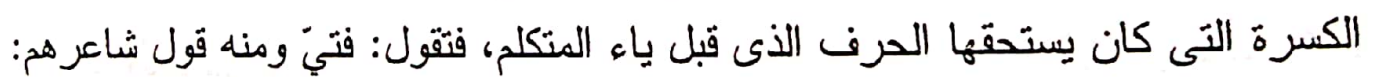

$$
\text { سبقوا هوي... البيت }
$$

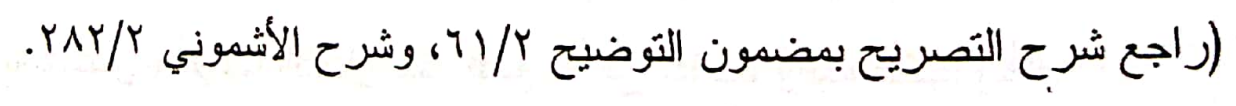
(r) البيت لأبي ذؤيب الهذلي يرثي أبناءه الذين داهمهم الطاعون.

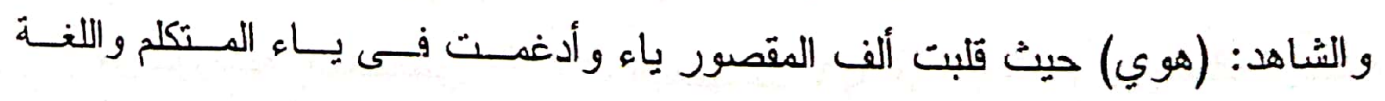
الأدبية فى ذلك بقاء الألف بلا قلب. 


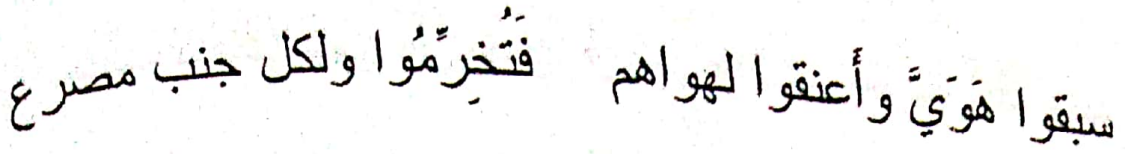

وروى عن قطرب قول الشاعر: (1)

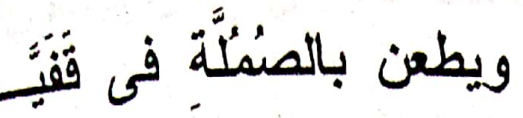

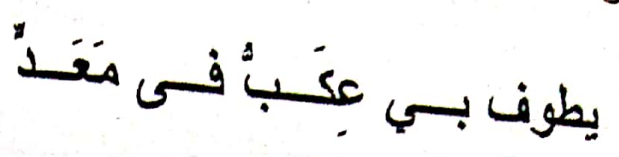

فلا أُرويتمــــا أبسـدا صنسـنِّا

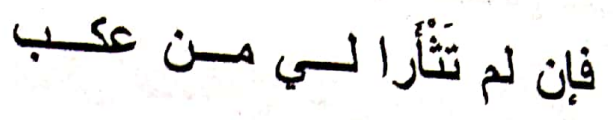
وقول الآخر:

أصالحكم وأســنـرَجْ نَوَيَّا

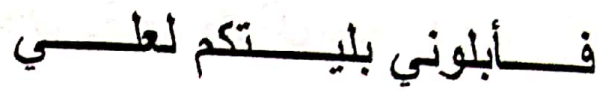

نلاحظ أن صوت الضرورة فى مثل هذه الأبيات لم يعل من ابن جني كعادته ؛ فكان تأويله للغة الشعر كتأويله لغة النثر ، ويعد كلا اللغتــين معـضدة للأخرى، فقال: ".. لم ير اعو ا حديث الاستخفاف و الاستثقال حسب، وأنـــه أمسر غير هما وهو اعتز امهم ألا تجئ هذه الياء إلا بعد كسرة أو ياء أو ألف لا تكون

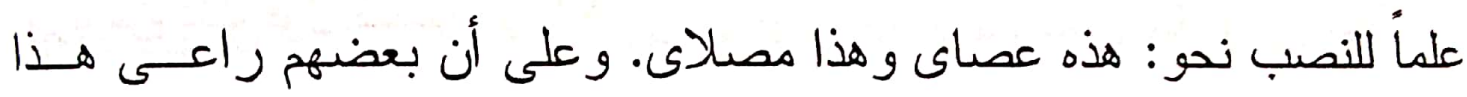

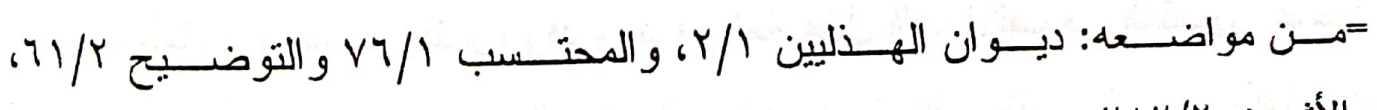

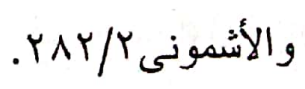

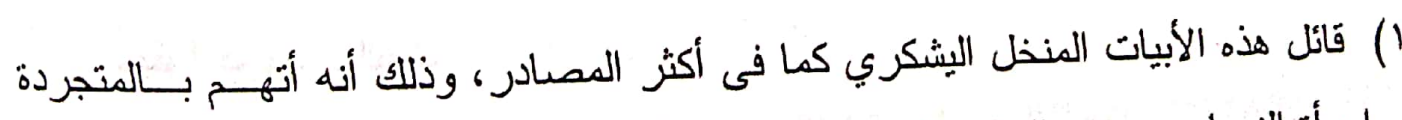

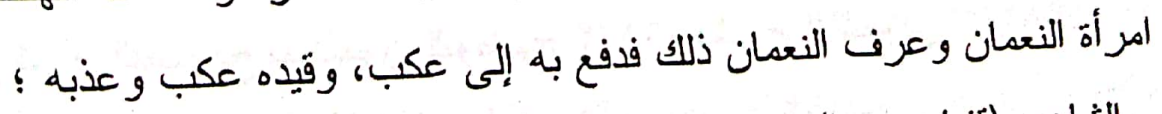
و الشاها: (قفيا وصديا) ووجه الاستشهاد كسابقه.

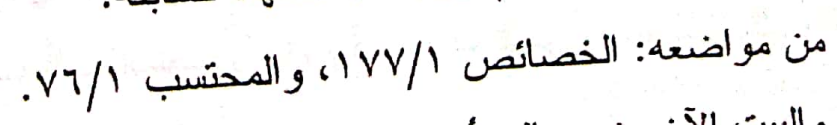

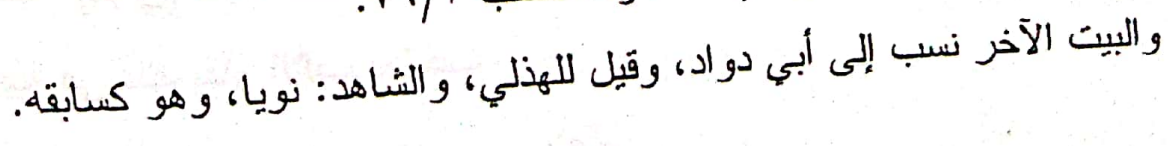
$09 r$ 
الموضع أيضناً فقلب هذه الألف باء فقال: عَصنيُ ورحي ويابشريخ هذا غلام.. " هـ (1) - مهر وذكر الأبيات السابقة.

ومر اد ابن جني من نصه أن ياء المنكلم تسبقها كسرة إذا لحقت المفرد

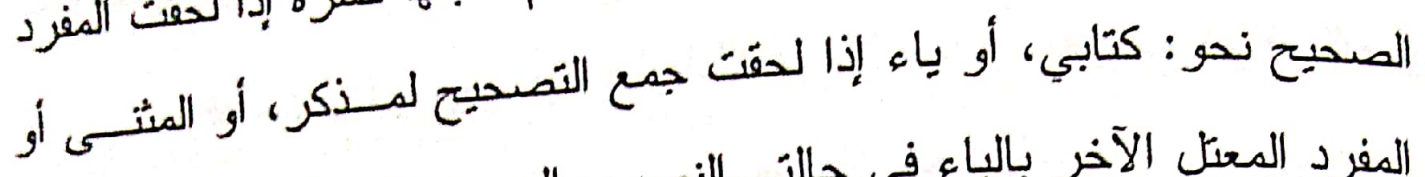
المفرد المعتل الآخر بالياء فى حالتى النصب والجر، ويتقلب الواو فى الجمع ياء

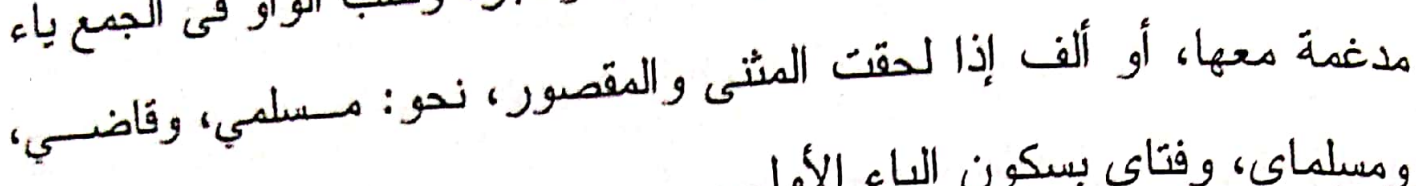
ومسلماي، وفتاي بسكون الياء الأولى.

و اضح من نصه السابق أن الخروج على اللغة الأدبية من قَبيلة كهنيل

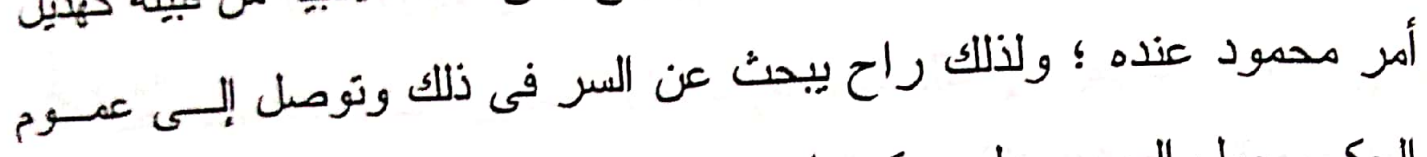

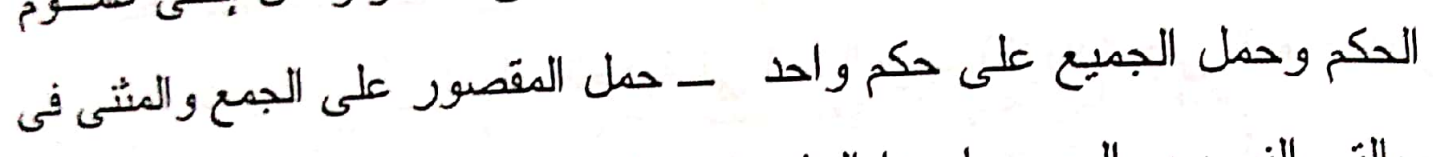

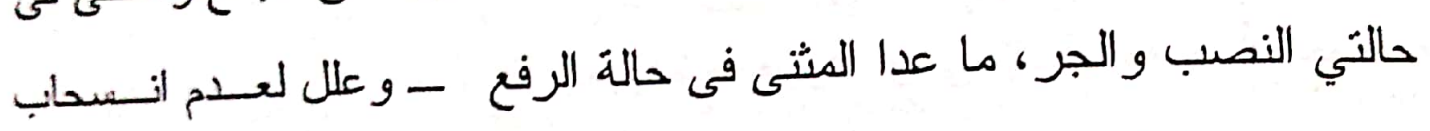
الحكم على المثنى المرفوع بمر اعاة علم الرفع. (r) ونحن نشير إلى ما حكم عليه ابن جنى بثنائية المستوى اللغوي ومــن ذلك ما ورد عن العرب في كسر شين عشرة وإبــكانها (آ). فـوردت اللفظـة

$$
\begin{aligned}
& \text { الخصائص IVT/I IVT }
\end{aligned}
$$

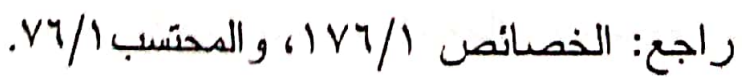

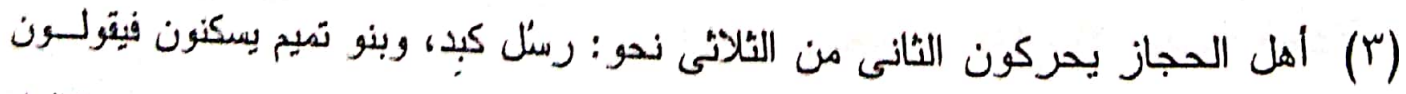

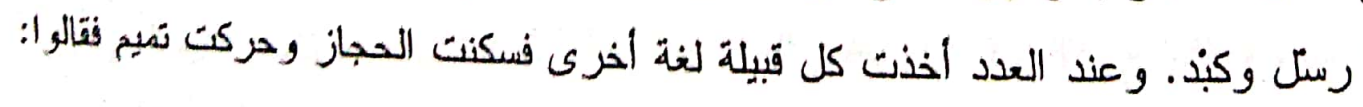
عشرة بالسكون، و عشبرة بالكسر عند بني تميلم.

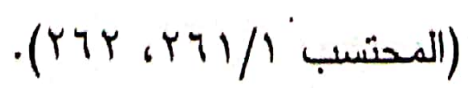

$09 r$ 
بتسكين الشين وكسرها، و التسكين عذد أهل الحجاز، و الكسر عند بني ذنمي، وهزا خلاف ما عليه الفريقان فى غير العدد ؛ فقى غيره السكون لغة تمبهم، والنحريك لغة الحجاز ؛ لأجل ذلك حدث تداخل بين اللغتين. وقد حاول ابن جني أن يعلل لذلك تعليلا منطقياً يتفق مع الو اقع اللغوى

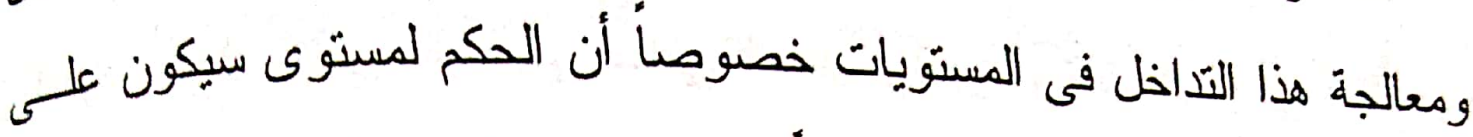
حساب الآخر من جانب، ويكون هدمأ للبنية التزكيبية التى بنيت عليها نسصف القاعدة النحوية من الجانب الآخر، وكان من الصعب عليه أن يكون قيمأ بسين

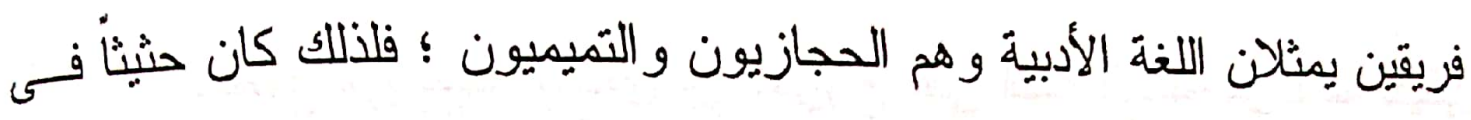
تقرير اته.

فذكر لللك أن الزيادة العدديةً فى لغة العرب (الزيادة على المفرد تكون

بالتثية والجمع) تكون بطريقة معهودة ومعروفة وهى تثثية المفرد أو جمعسه،

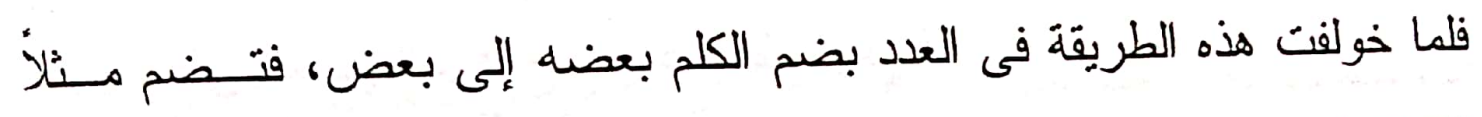

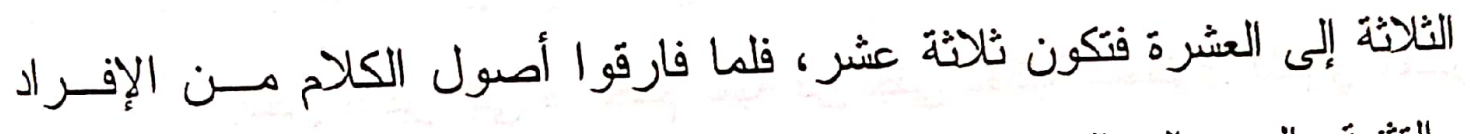

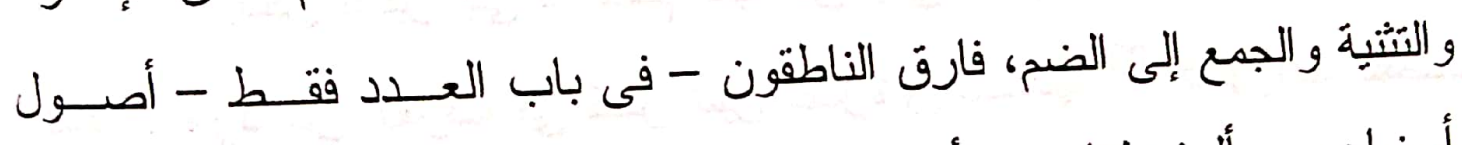

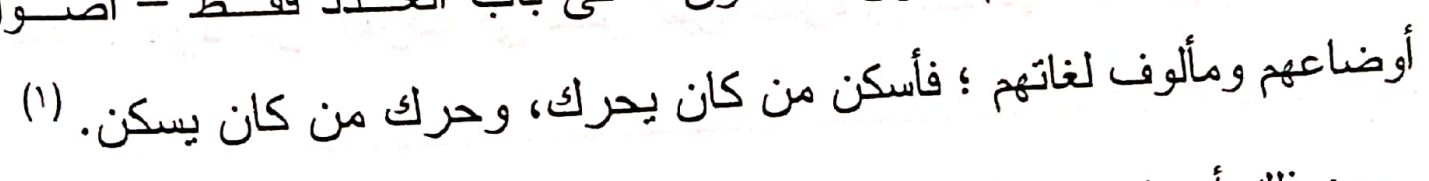

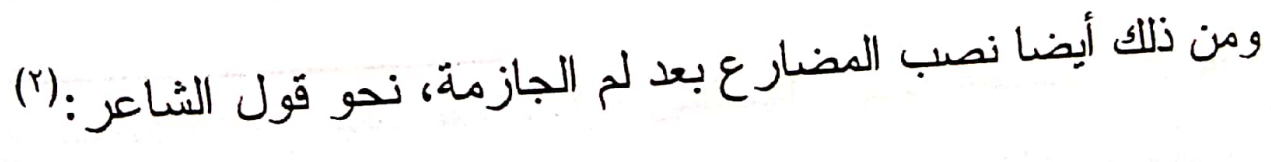

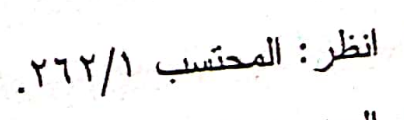

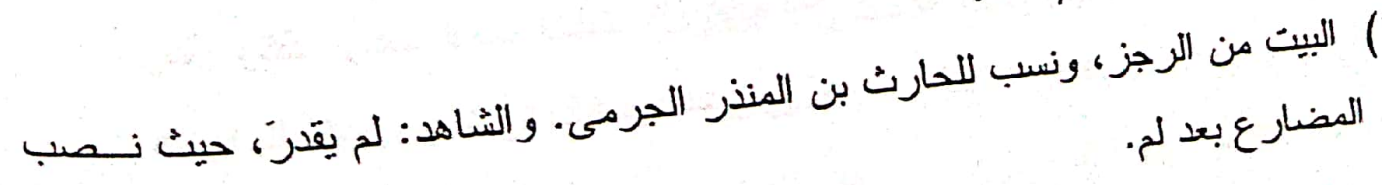




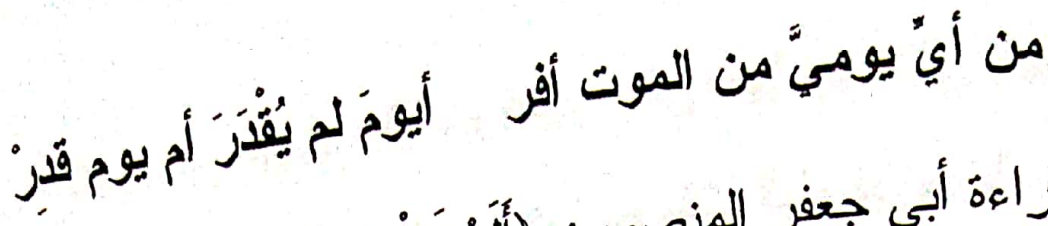

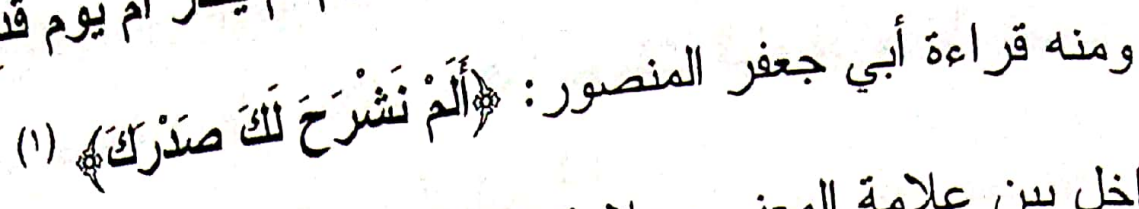
ثالثاُ: التذاخل بين علامة المعنى و علامة المبنى: أدى التشابه بين العلامات التى تلحف آخر الكلمة وبين حروف المبنى

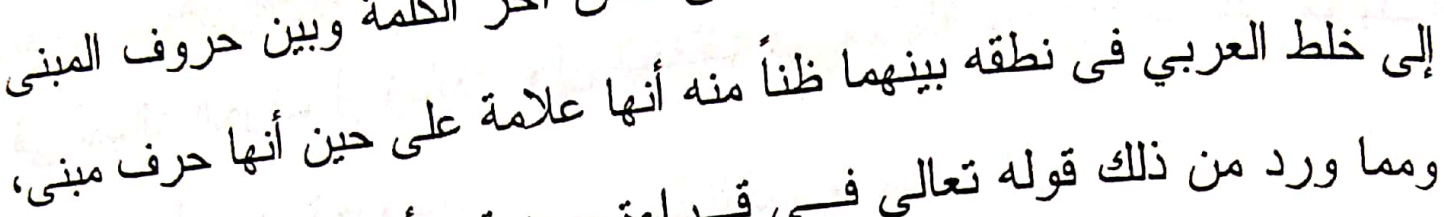

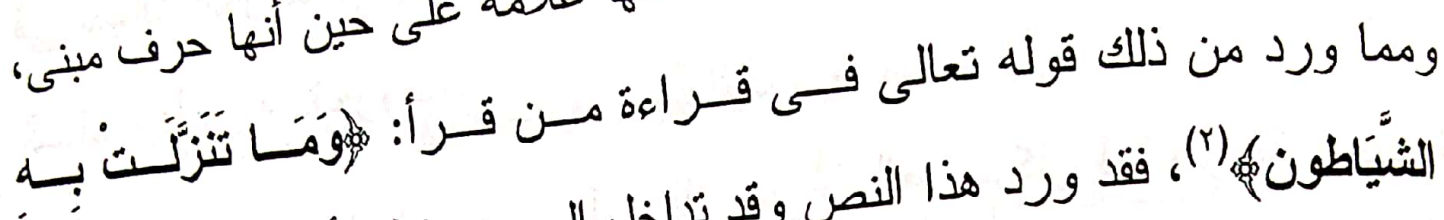

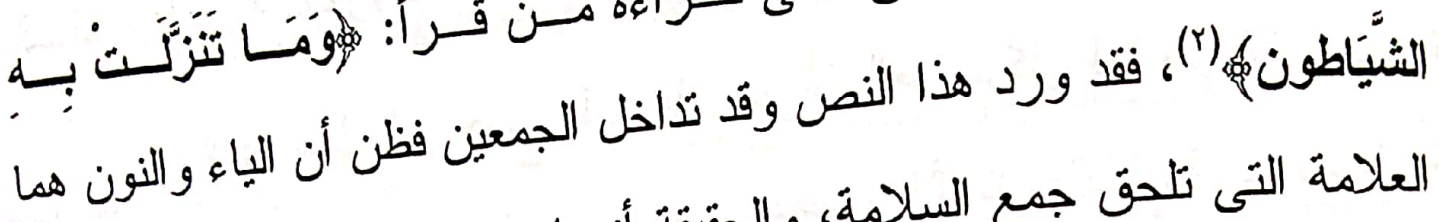

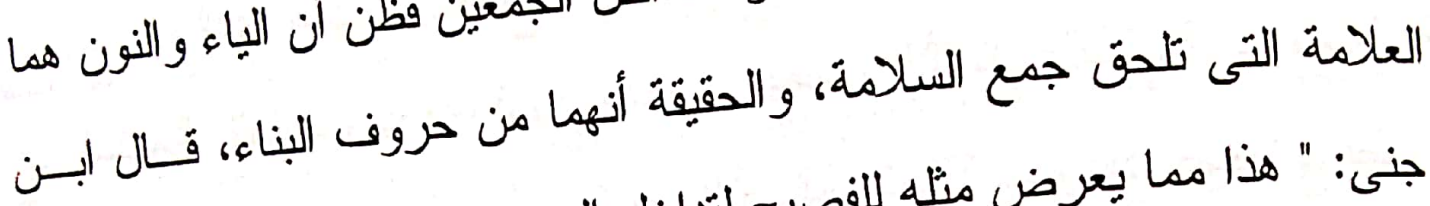

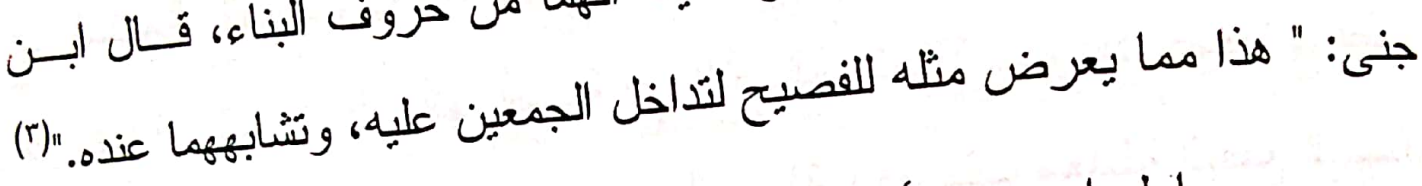
وحاول ابن جنى أن يجد لذلك علة وسبياً ووجهاً مقربأ لها فلم يجد إلا

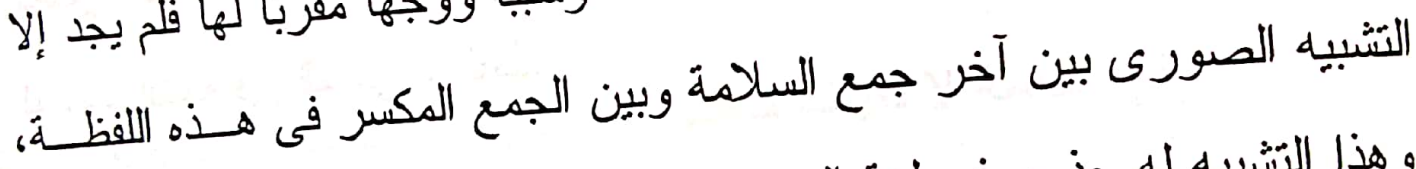

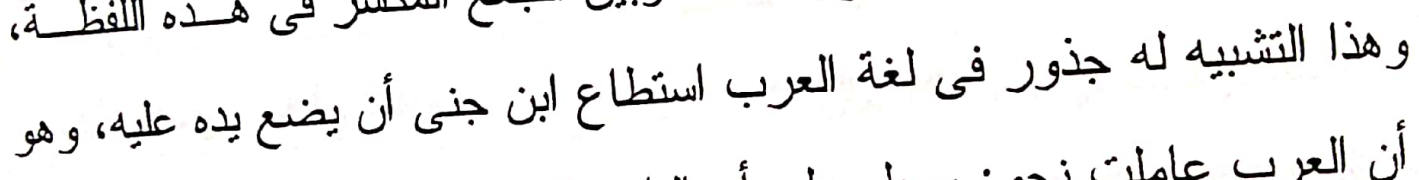

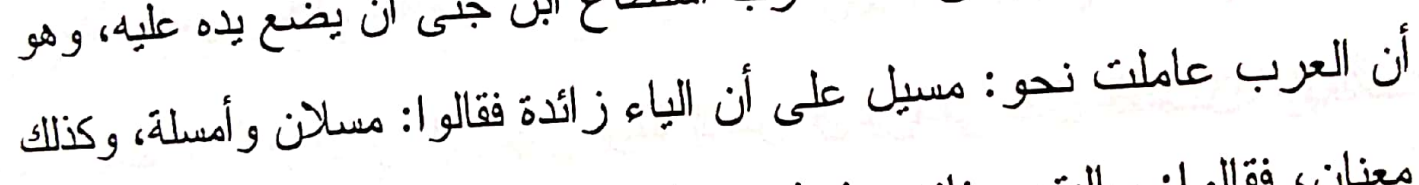

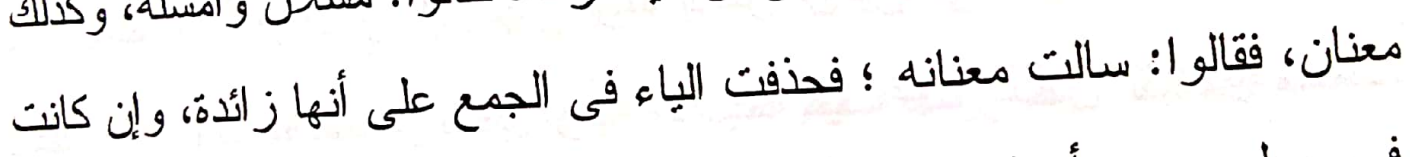
فى مسيل ومعين أصلية.

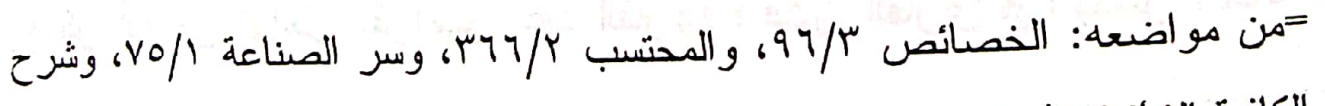

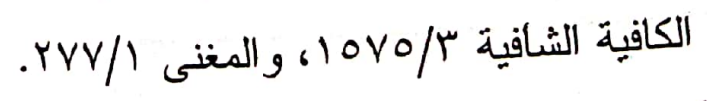

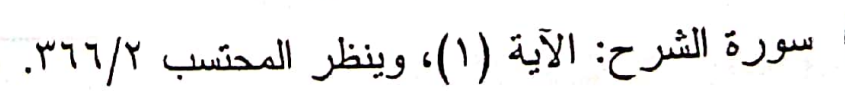

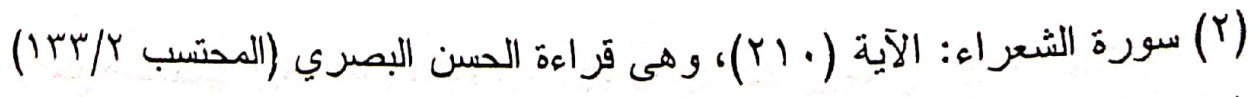
المحتسب r/r (r 
فثياطون عوملت الياء و النون على أنها زائدة فى الجمع، وإن كانه

فى الهفرد أنهائ زائدة وهى فى المفرد أصلية. لكن التشبيه الذى عناه ابن جنى ليس فى صلب القضيةً ؛ فالخلاف لبير فى أهالة الحرف أو زيادته، وإن الخلاف فى معاملة الجمع المكسر معاملـن

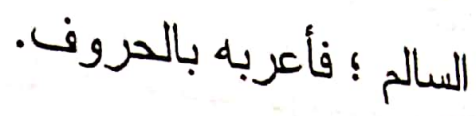
و الذى حمل ابن جنى على ذلك هو أن العرب كان لها طريقة عبيـة.

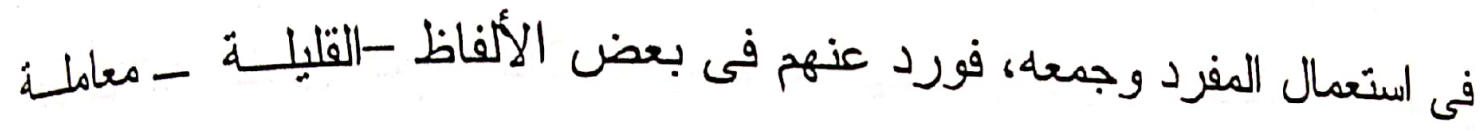
حروفها فى المفرد على أنها أصلية - و الأصالة منحققة - و عند جمعها يسقطون بعض الألفاظ، وقد شبهت شياطون فى المعاملة ؛ فعوملت معاملة الجمع السسالم لوجود الثبه فى المعنى و اللفظ.

\section{رابعاً: تصوير حال القائل:}

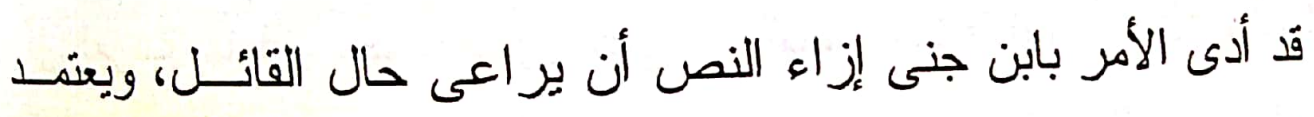

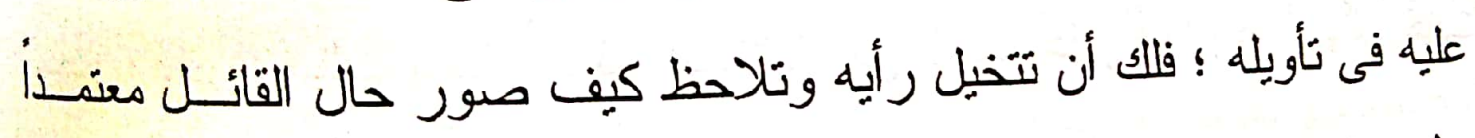

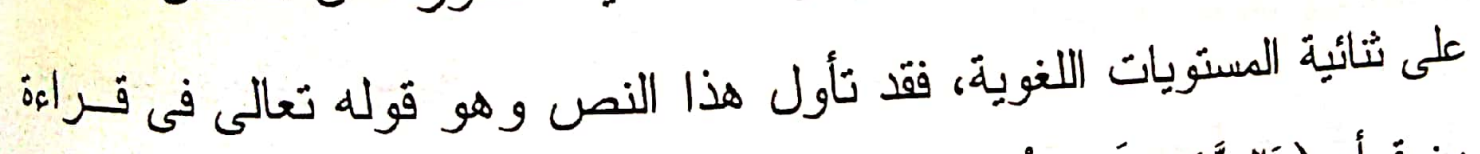

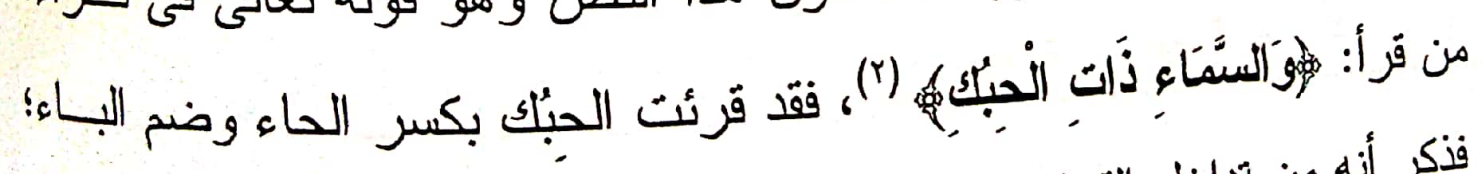

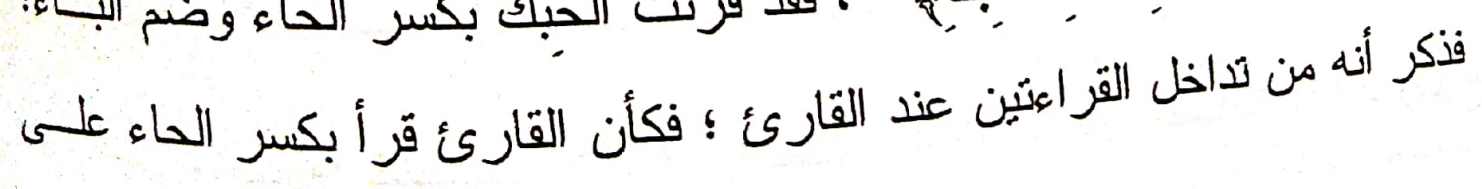

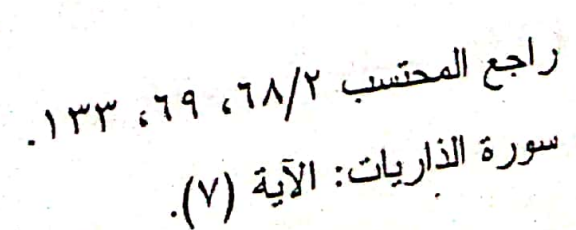


قز اءة كسر الحاء و الباءكاثم أدركته قر اعة الضم بعد النطق بالحاء فقر أبها آخسذأ

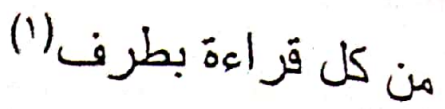

فقد نظر ابن جنى إلى حالة القارئ وفرض فروضاً يمكن أن تقع فـى

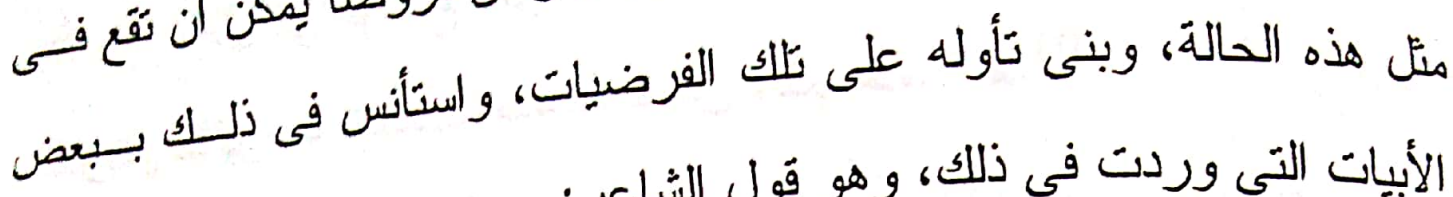
الأبيات التى وردت فى ذلك، وهو قول الشاعر :

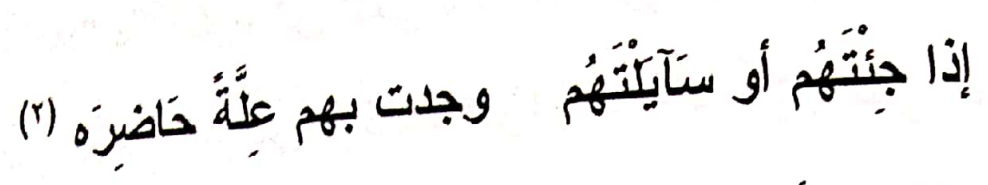

وذلك أنه يقال: سألته عن حاله، وسايلته بإبدال الهززة ياء ؛ فلما ألـف

استماعهما تجاذبتا لفظه فجمع بينهما لتذاخلهما وتز احم حروفهمسا ؛ فتـداخلت اللغنان على القائل فجمع بينهما لاستحضار اللغتنين فى ذهــــن القائسل حسال (النطق . (r)

وفى الحقيقة لا نعرف مقصود ابن جنى هل بقصد تزكيـب لغتــين أم

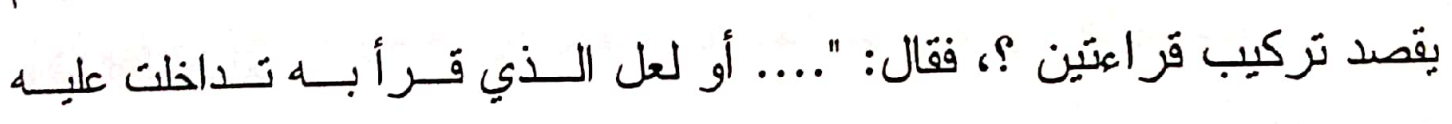
القر اعتان: بالكسر و الضم. فكأنه كسر الحاء يريد " الحبِك "، و أدركه ضم البــاء على صورة " الحُبّك " وقد يعرض هذا التذاخل فى اللفظة الواحدة... فجمع بين

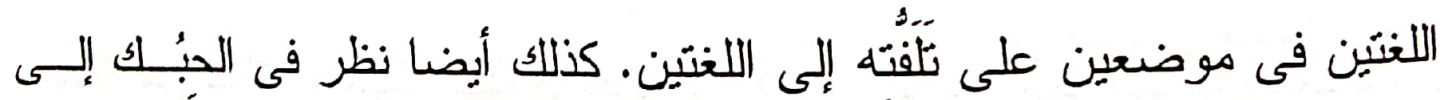

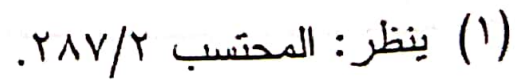

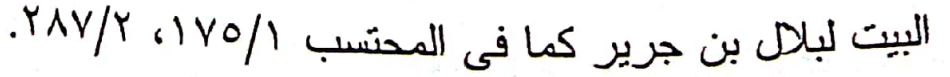

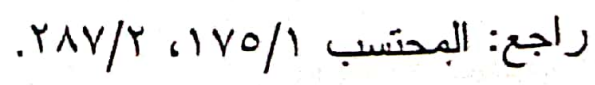




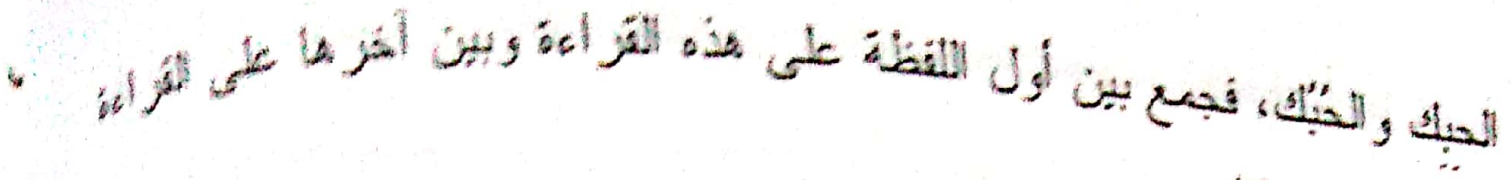

(1) " الأخزى

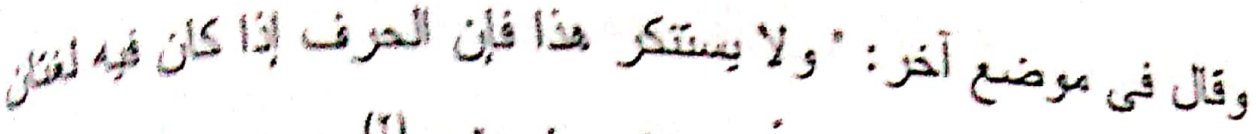

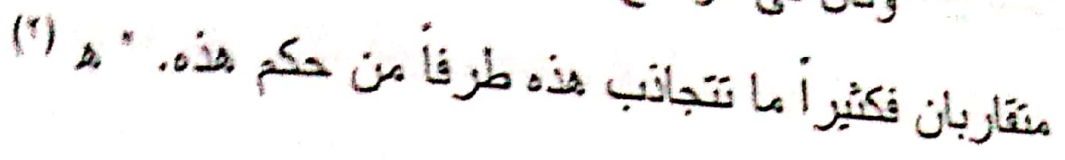

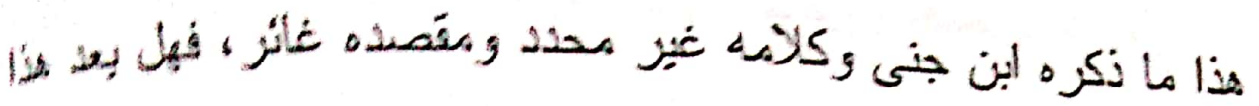

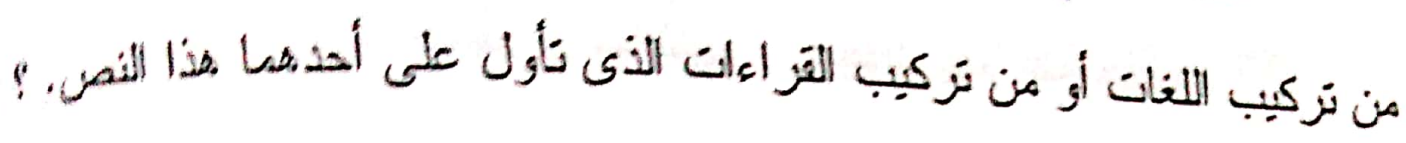

وفى الحقيقة فى التزكيبين بعض الثنئ فلو قلنا إنه من نز كيب اللاغسات

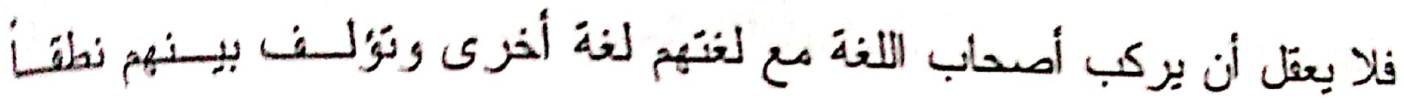

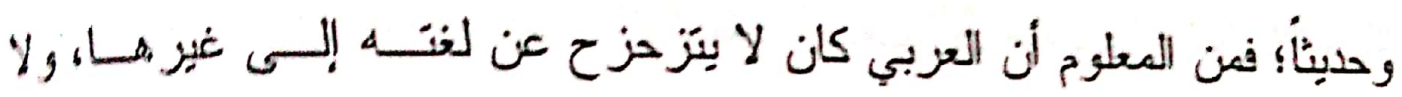

ينتبلها ولو بصوت واحد. كما أن القول بالتزكيب من لغنين دليل علــى أنهـا

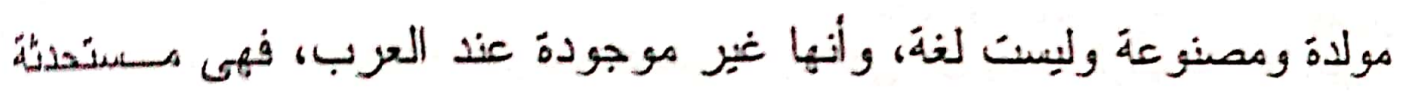
ومختقةَ من لغنينن.

ومدار الأمز كله مبنى على الصنعة فابن جنى قاس هذه اللفظة على ها

ورد من أبيات عند العزب والأمر مختف كل الاختلاف فما ذكره من نزكيــب

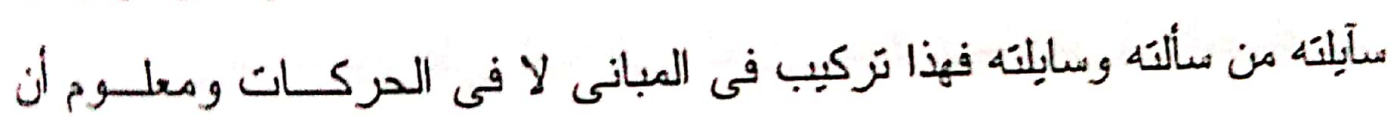

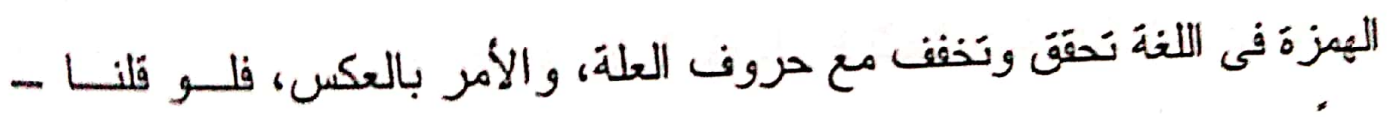

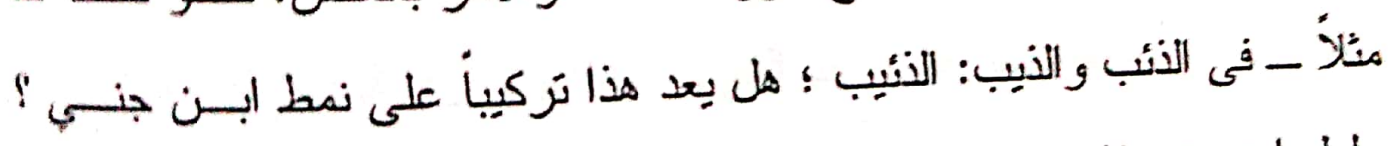

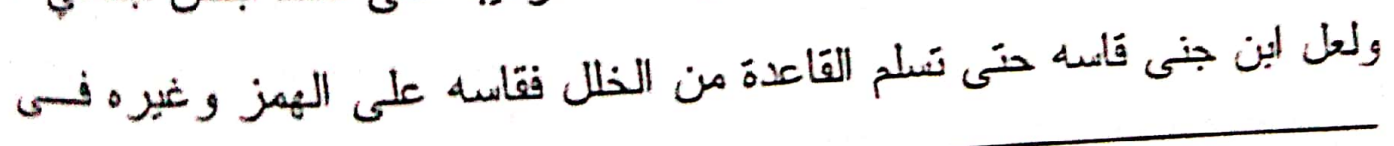

$$
\begin{aligned}
& \text { المحتسب Y Y }
\end{aligned}
$$

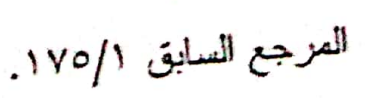




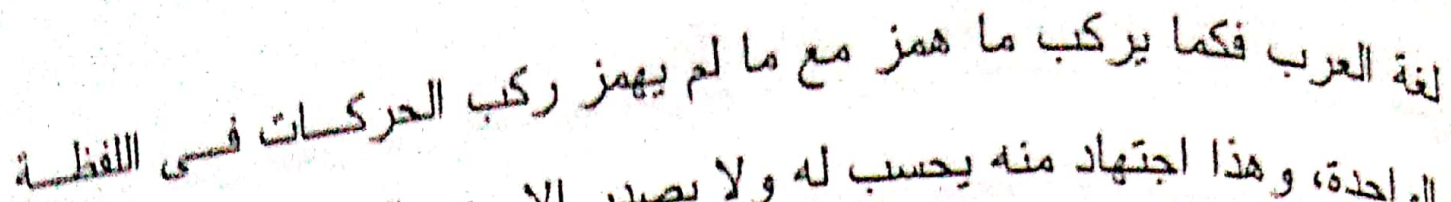

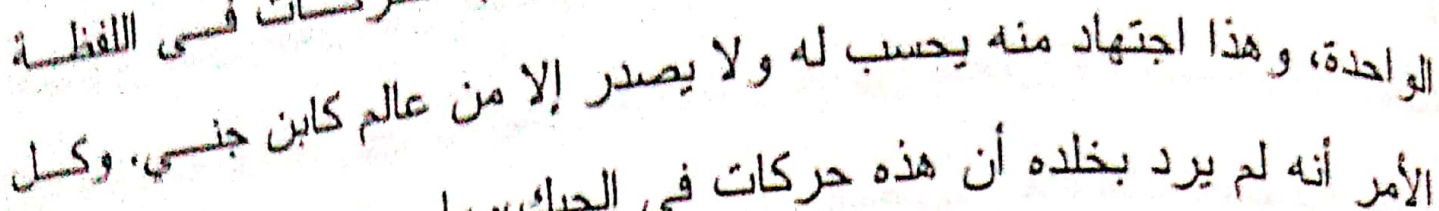

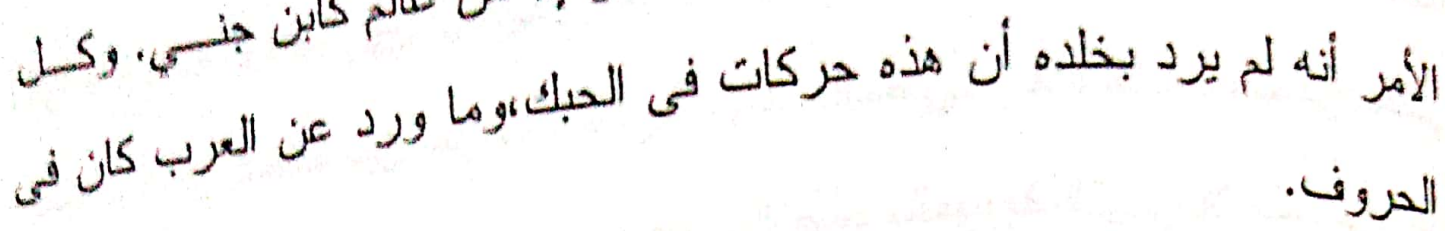
أما على احتمال أنه من تركيب القراءات فهو - وإن كان وارداً ـ فقد

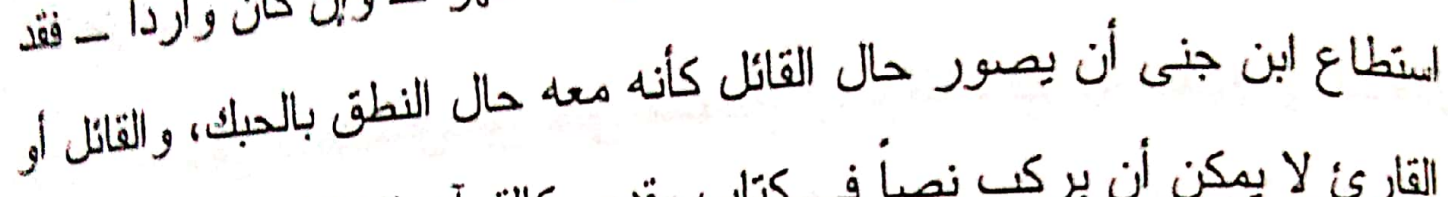

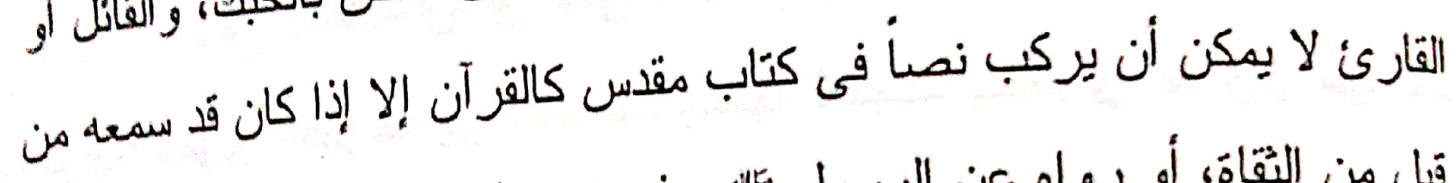

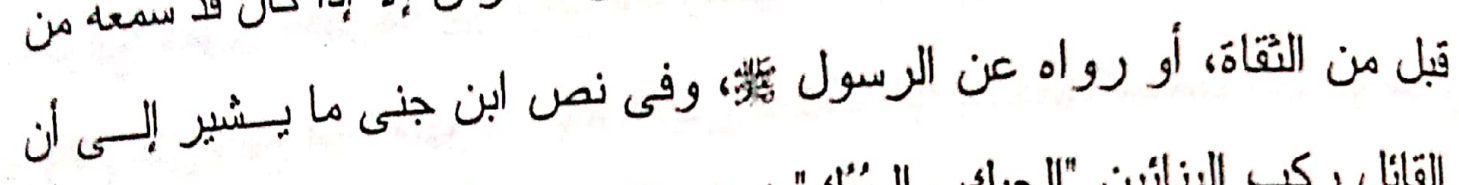

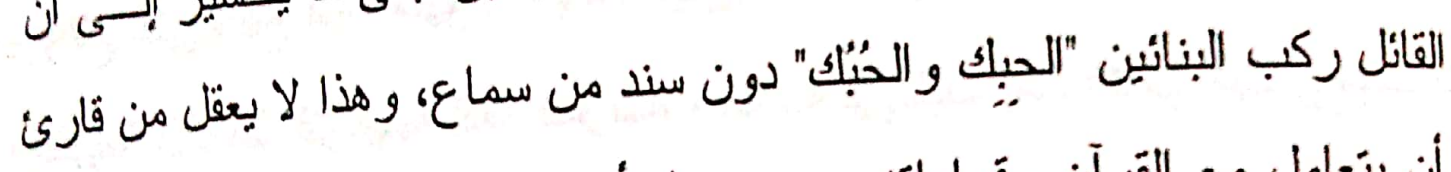

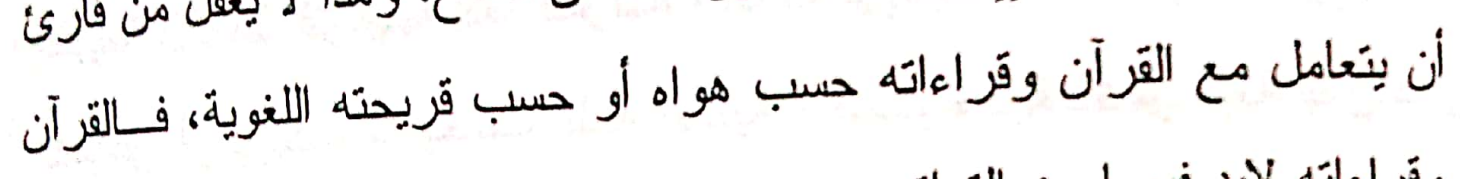
وقر اءاته لابد فيهما من التواتر.

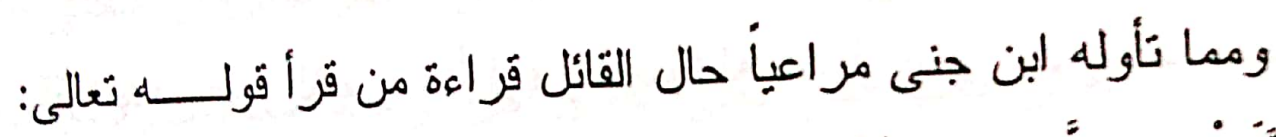

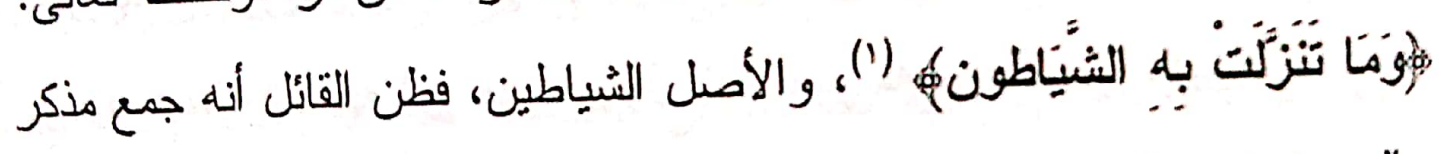

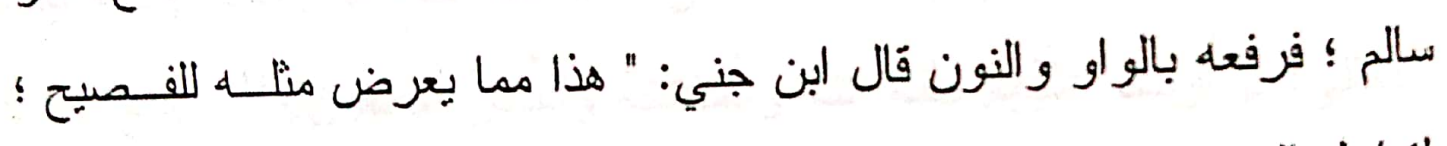

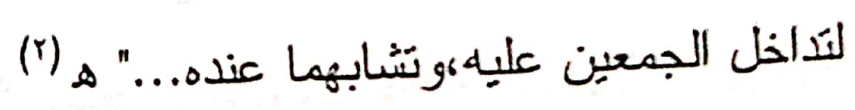
وقَد ذكرت ذلك فى التذاخل بين حرف المبنى وعلامة المنىى مما بغنى عن إعادنَه هنا.

$$
\begin{aligned}
& \text { سورة الثعراء: من الآية (.r) (r). } \\
& \text { المحتسنب r }
\end{aligned}
$$




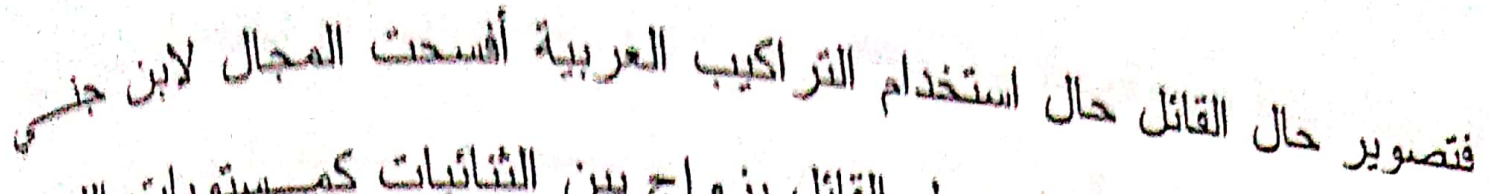

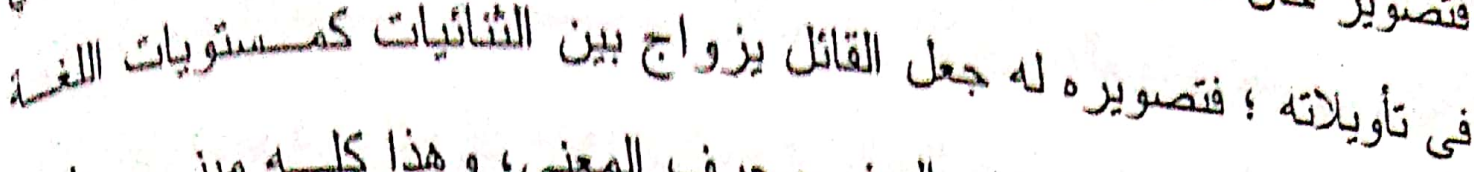

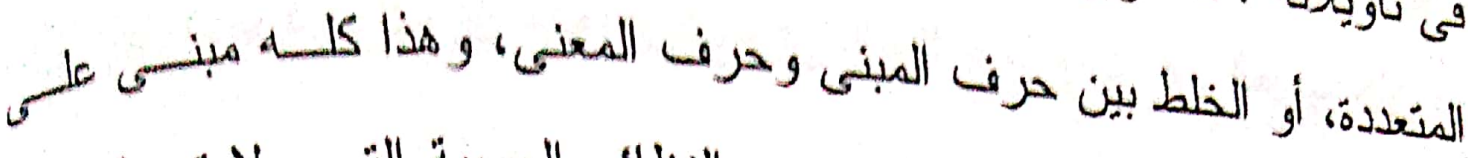

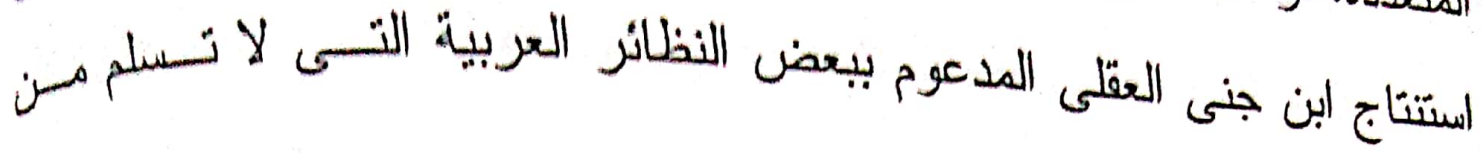
الاعتر اض.

وفى الحقيقة أن ابن جنى استطاع أن يوظف قدرئه العقلية فى استغلال الواقع اللغوى ؛ فمزجه بين واقع مستوياتها المتعددة بدقة وبر اعة جعل من ثأويل

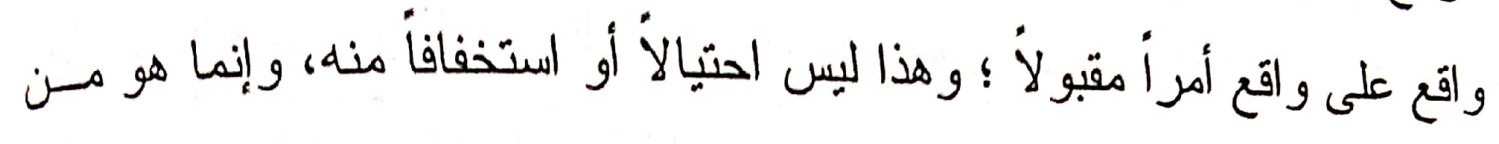

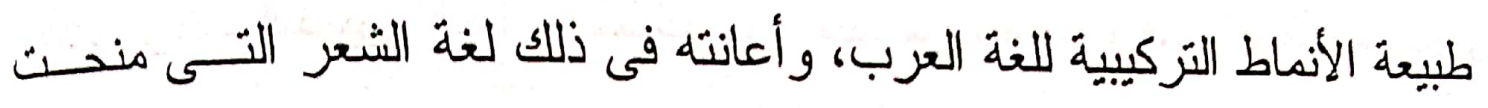
للشاعر أن يرتكب ما يخالف اللغة الأدبية ؛ فمساو اة لغة الشعر بلغة النثر فـى لئى عملية التقعيد من قبل النحاة فتحت المجال لحمل الكثير من المنتـــور المخــالف

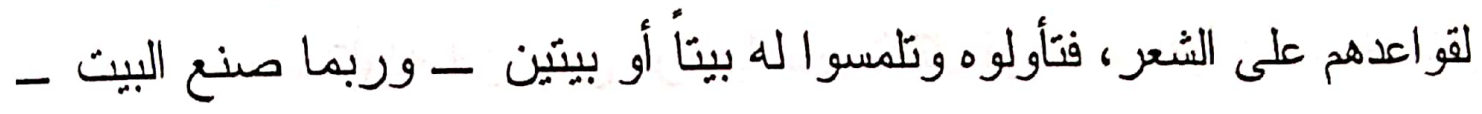
وهذا ما فعله العلامة ابن جنى، يؤول ثم بلتمس له من الشعر ما يؤكده. 
هذه الآلية استخلها ابن جنى معنمدأ على الوظليفة النحويسـة، وذلـلك أن النماة وضعوا القاعدة على أساس من السلامة والاستقر اء للنص ؛ فظنوا أنهـا

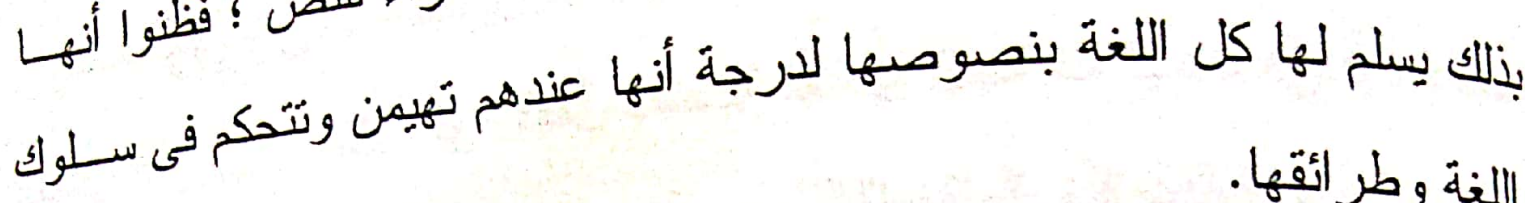
اللغة وطر ائقها.

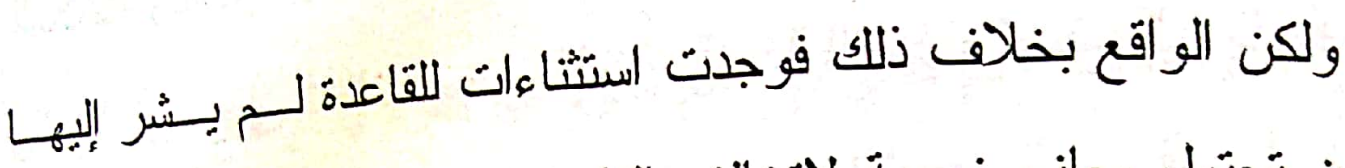
الوضاعون تحتمل معانى نحوية لاتخالف القاعدة فى جوهر ها، وإنما هى مسن جزئياتها وتفصيلاتها ؛ و هذا شأن كل قاعدة لا بد من وجود خوارق فى الغالب تخرج عنها فى الظلهر، ولكنها نحمل وجهاً آخر، ويكون لها وظليفة نحوية غبر التى بوحي إليها ظاهر النص.

وقد استغل ابن جنى هذه المخالفات الظاهرية التى يمكن أن تستنى من

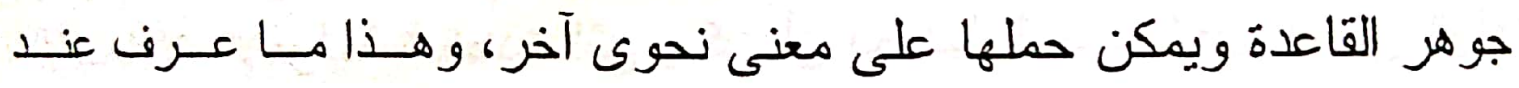
النحويين بالأوجه الإعر ابية المحتملة فى اللفظة الواحدة، فمن ذلك تأولـه قولـهـ

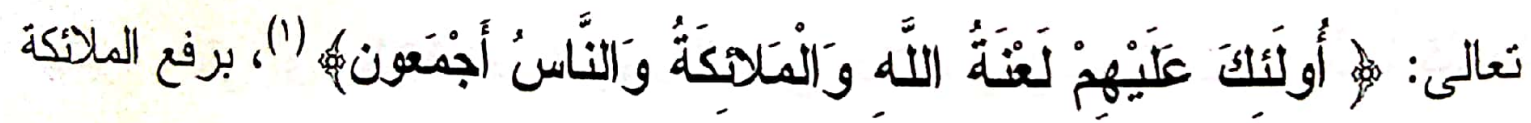
و الناس و أجمعون ؛ فالقاعدة توجب عطف الملائكة و الناس على لفــ الجلالــة المجرور، فأوجد ابن جنى لرفع المالئكة و الناس وجها إعرابياً تحمل عليه اللفظة.

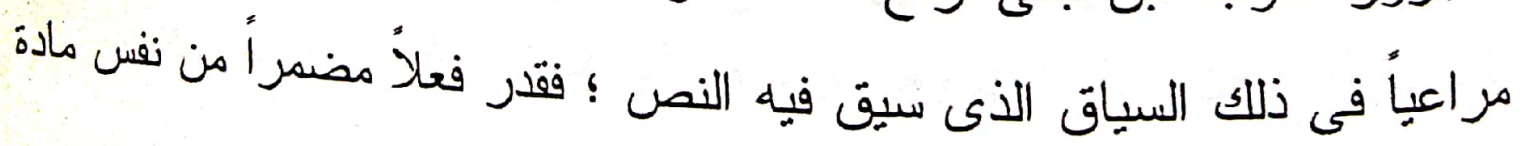
المصدر (لعنة) 


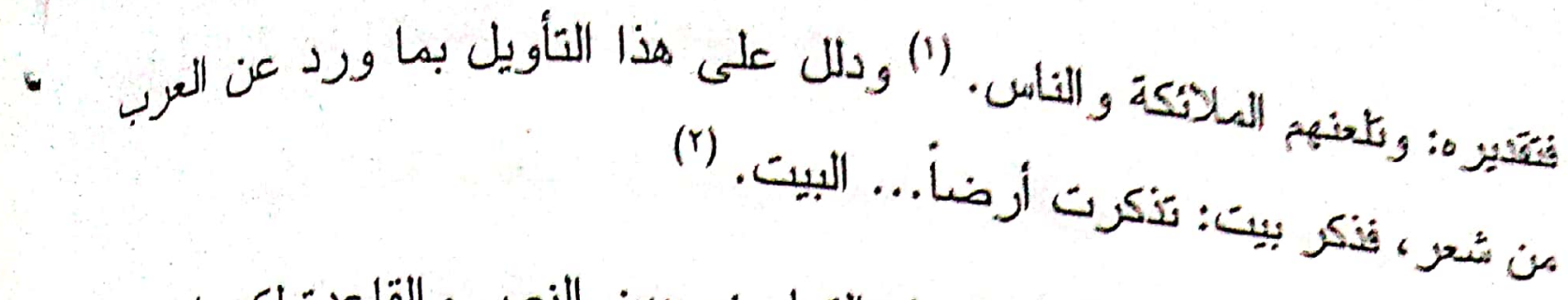
وإن كان هذا التأويل قد حل التعارض بين النص و القاعدة لكن إضمار الماهل أدى إلى اختلاف قوة الفعل بالنسبة للفاعل فلعنة الله ليست فى قوة لعنسة الملائكة والناس، أبـا العطف فيدل على عموم اللعنة وقوة انصبابها من الخـالق

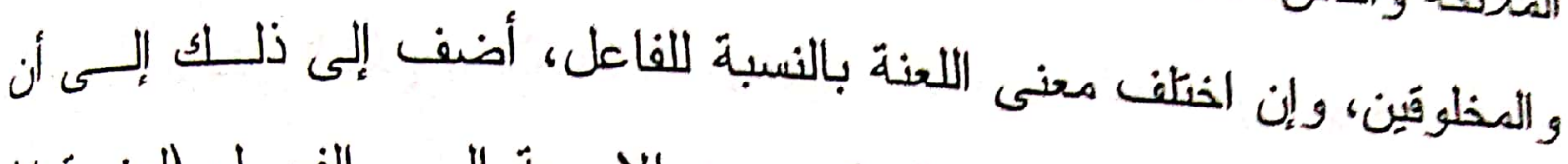
إضمار الفحل بحد الواو قد حول التزكيب من الاسمية إلـى الفعـل (لعنــة الذه

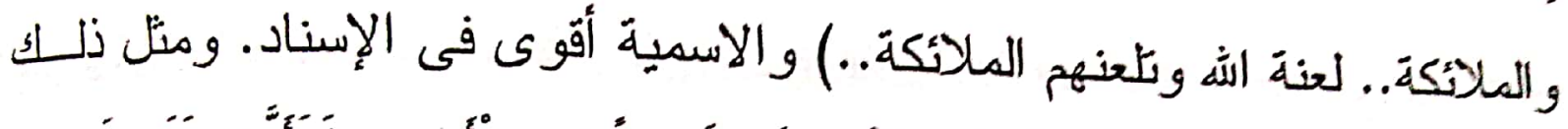

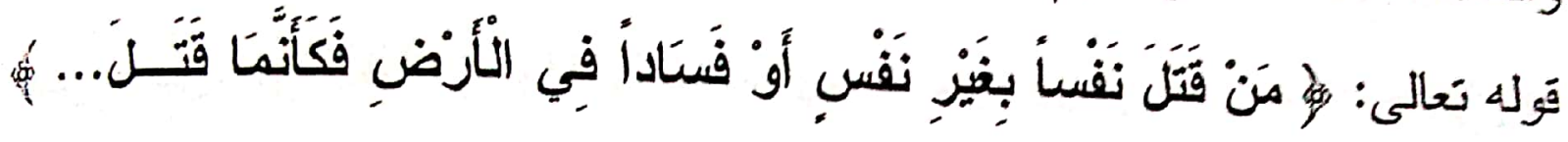
(الآية

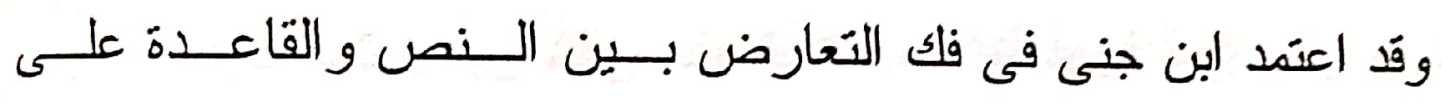
الاحتمالات الإعرابية المتعددة التى يمكن أن يحملها النص داخل المعنى الواحد

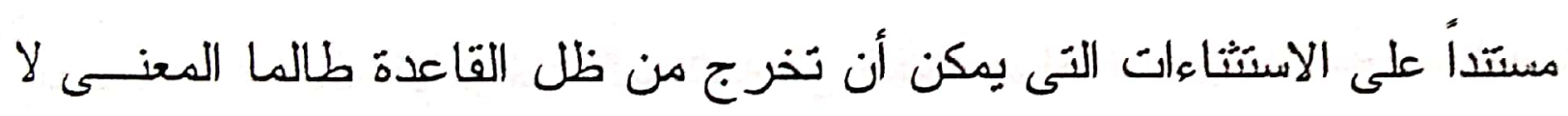

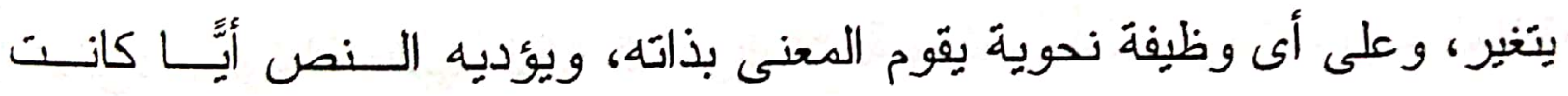
وجعته، وهذا اللون كثير جداً عند ابن جنى و المتصفح لكتبه يلمس هــــا جليـاً. واضداً ؛ لذلك أكتفى بما سبق من نماذج لصعوبة الحصر ، وسآمة الإطالة.

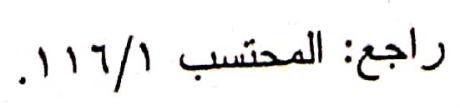

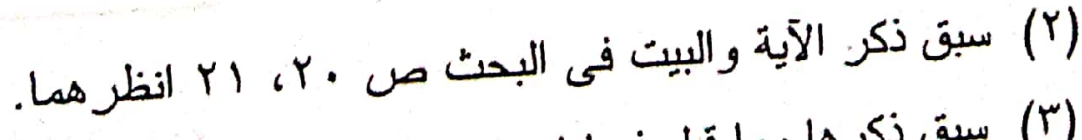

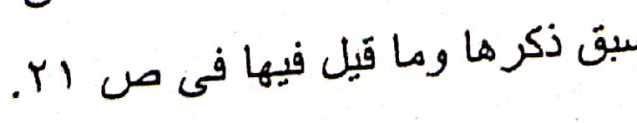


هناك نصوص خالفت القانون الإعر ابى، وتأولها ابن جنى على التسبياه

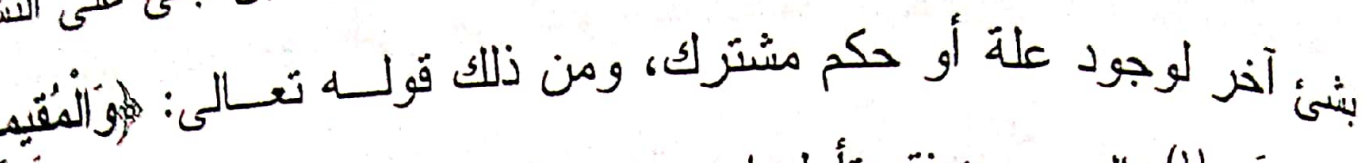

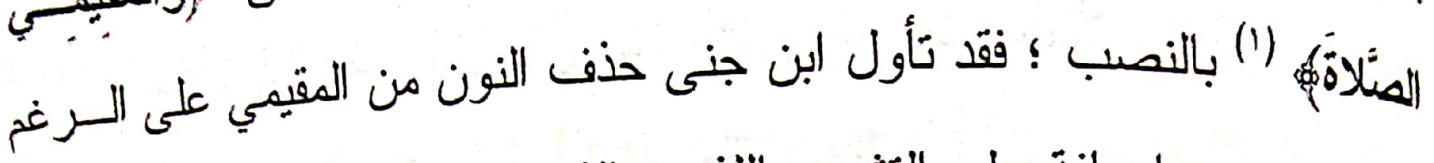

من عام وجود إضافة على التشبيه باللذين والذين فى قول الشاعر : (؟) فإن الأى حانت بقلج دماؤهم هم القوم كل القوم يا أم خالا

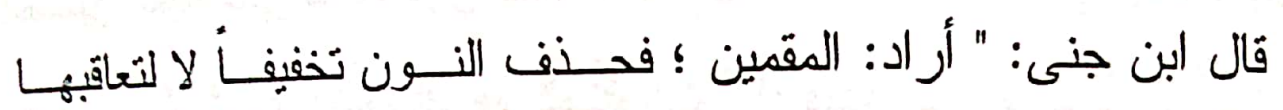
الإضافة، وشبه ذلك باللانين و الذين فى قوله: (فإن الذى...... البيت) حذن النون

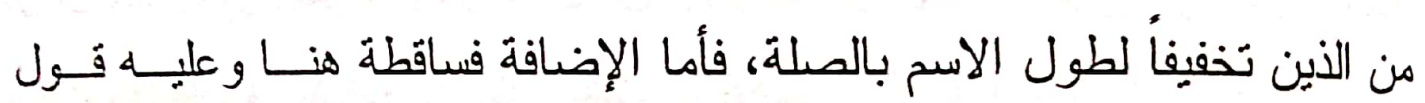
الأخطل: (r) أبنى كليب إن عمى اللأ قتلا الملوك وفككا الأغلال

حذف نون اللذان لما ذكرنا. " هـ (؛)

$$
\begin{aligned}
& \text { (1) سورة الحج: من الآية (ب0)، وهى قراءة ابن أبى إبحاق، والحسن، ورويت عن أبىى }
\end{aligned}
$$

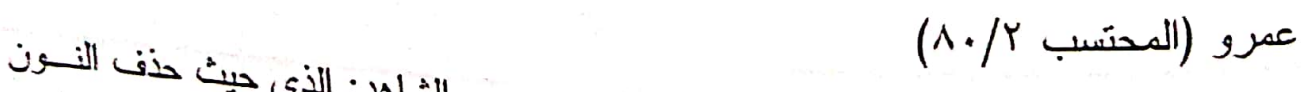

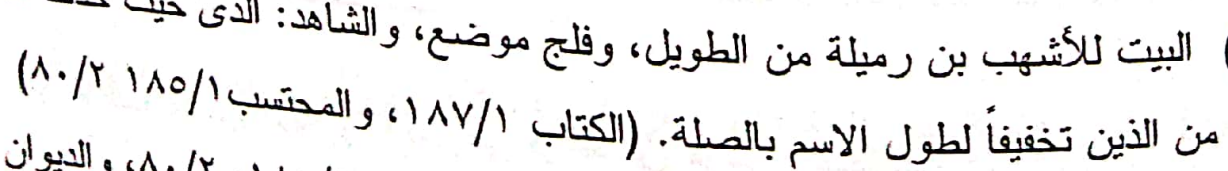

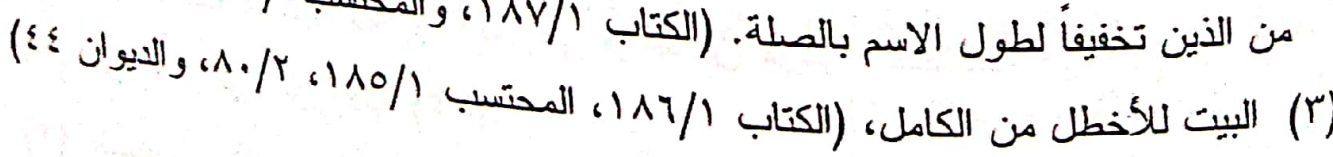

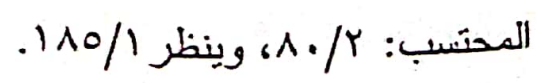


هذا ما ذكره ابن جنى فى تأويله، ولكن الغريب فى هذه القضيةً أن بر

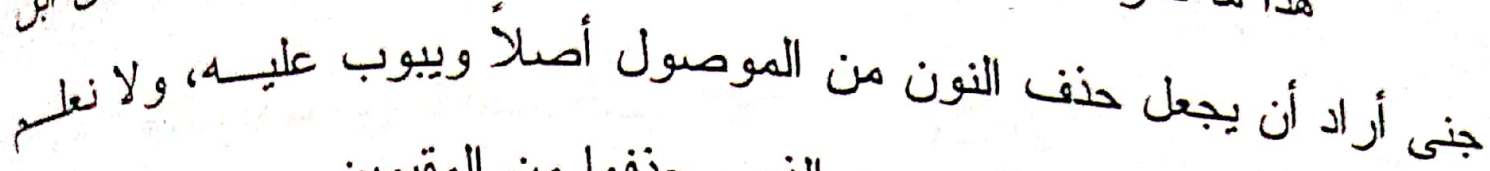
وجهأ للمشابهة بين حذف النون من الذي وحذفها من المقيمين. أضف إلى ذلاك أنه رفض حذف النون من التى حملاً لها على حـنها

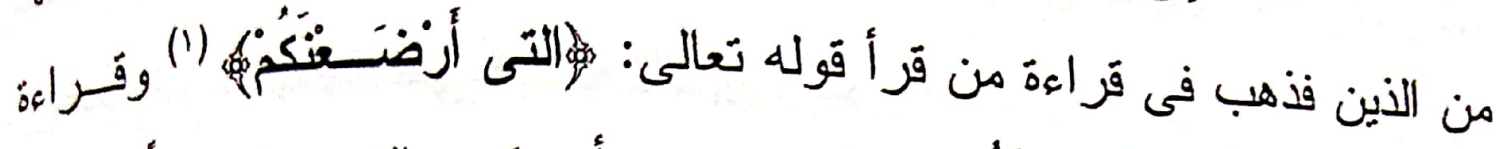

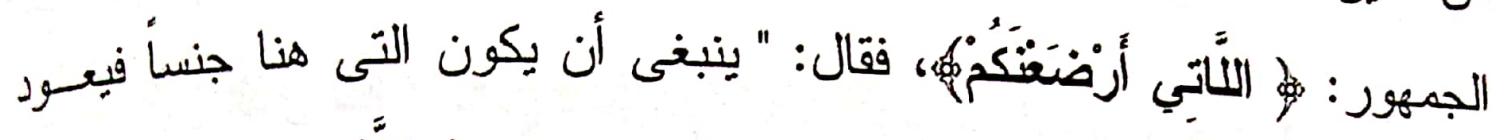

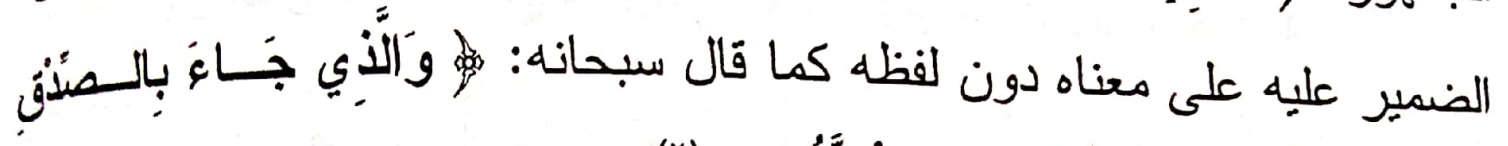

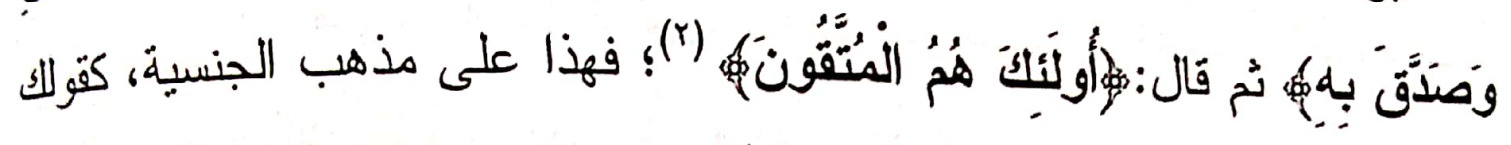
الرجل أفضل من المر أة، وهو أمثل من أن بعتقد فيه حذف النون من الذى كمـا

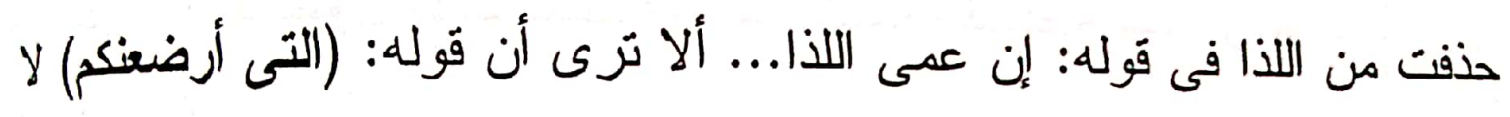
يجوز أن يعتقد فيه حذف النون ؛ لأنه لا يقال: اللتيّن، و القول الآخر وجسه، ألا

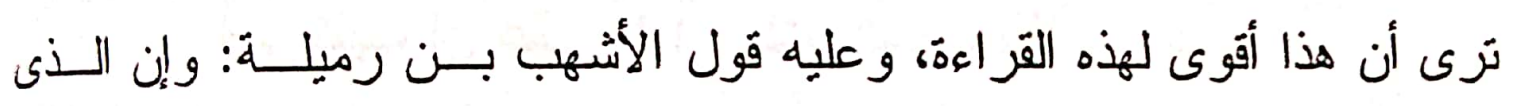
حانت... إلخ يحتمل الذذهبين حذف النون من الذين، و اعنقاد مــذهب الجنسية

$$
\text { (r) على ما مضى." (r) }
$$

فرفض المشابهة بين الذي و التى فى حذف النون منهها، علـى حسين

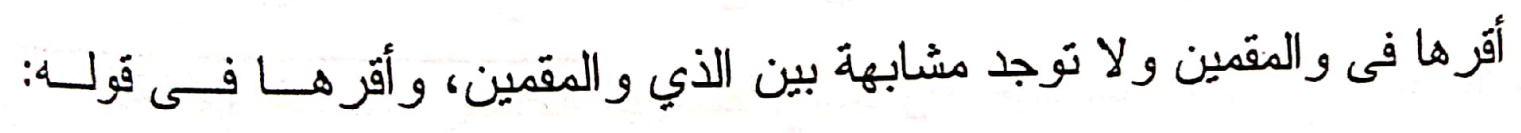

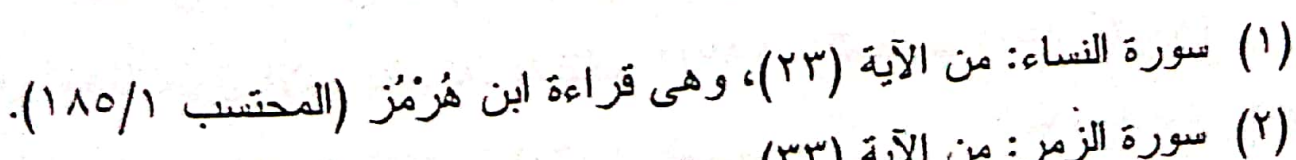

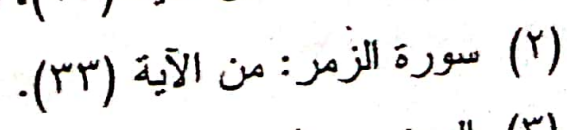

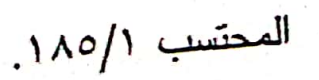




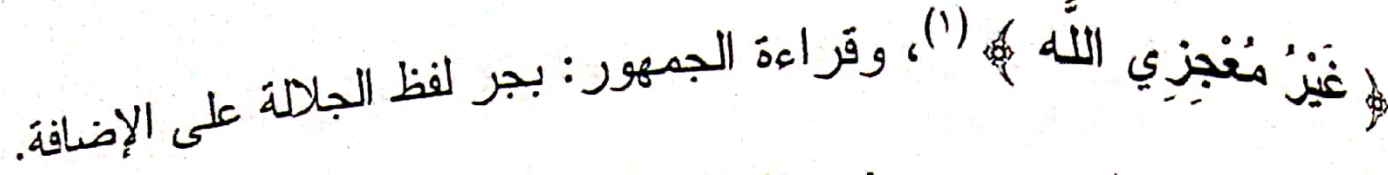

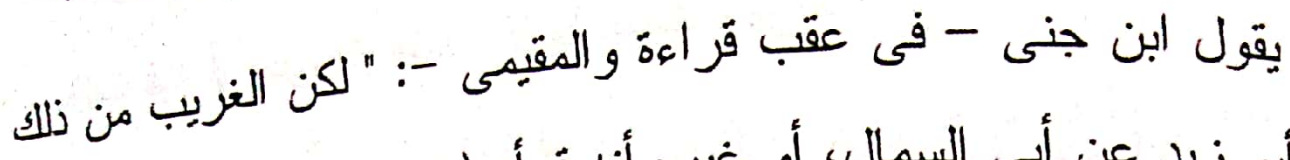

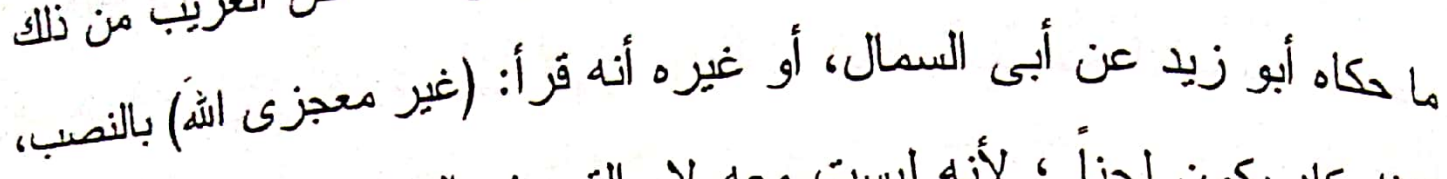

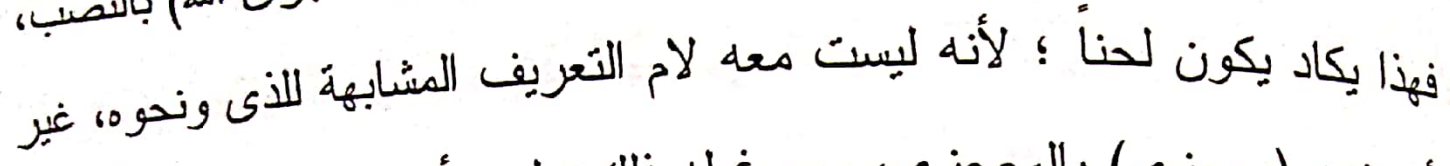

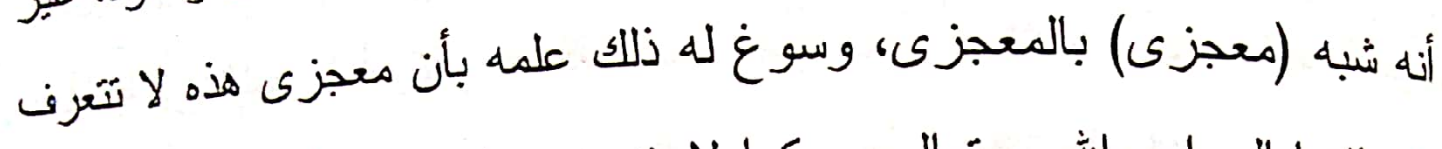

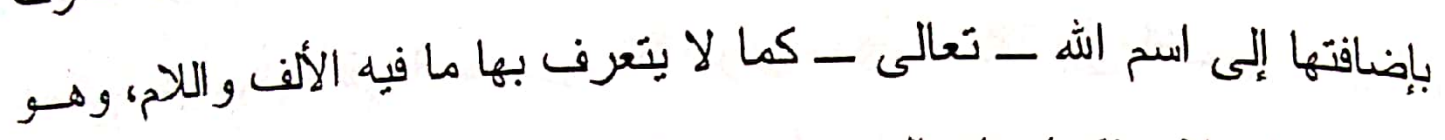
المقيمى الصلاة، فكما جاز النصب فى " المقيمى الصلاة " كذلك شبه به " غئر

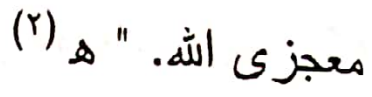

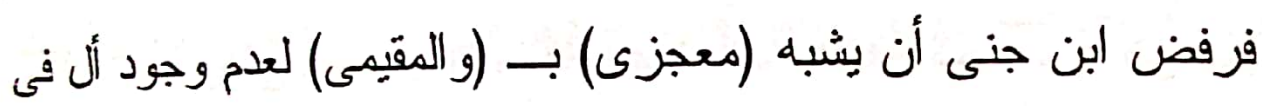

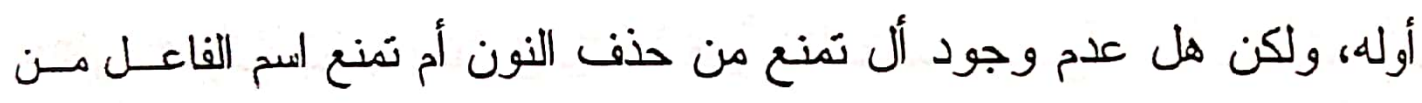

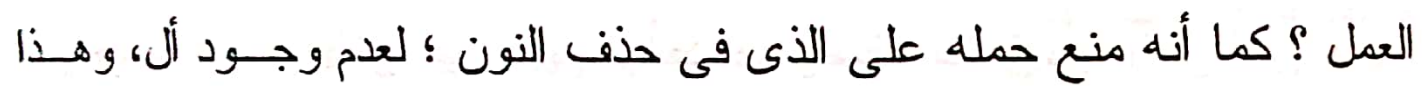

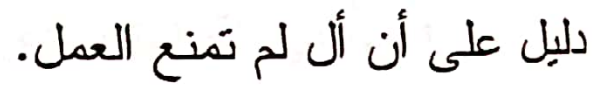

لكن ابن جنى حمل معجزى على المعزىى، وذكر كلاماً مرسأ لا يُّفع

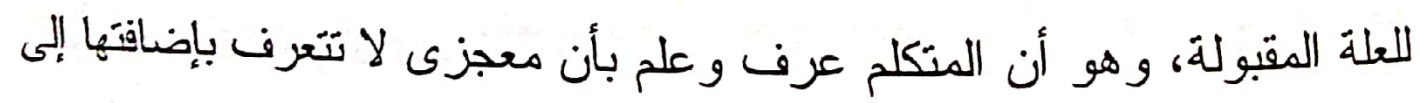

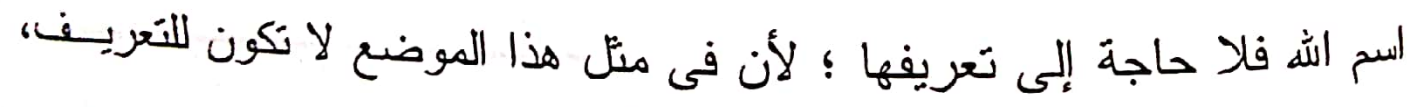

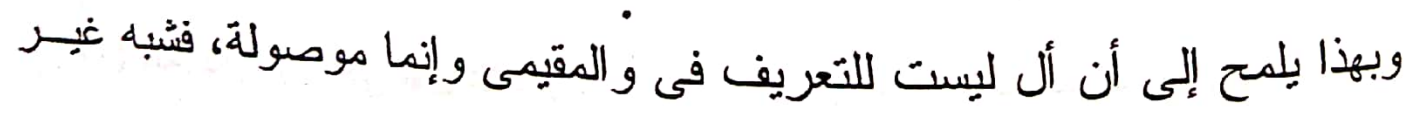

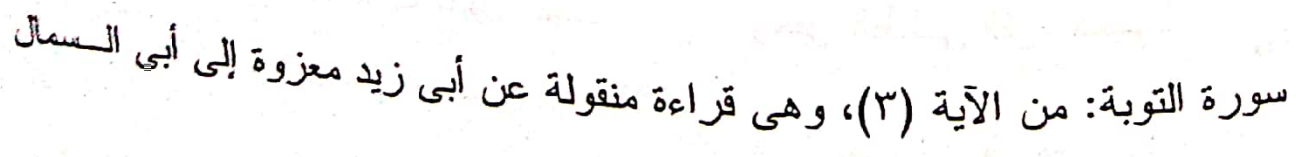

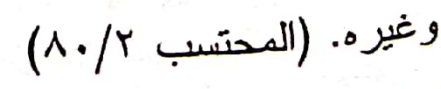

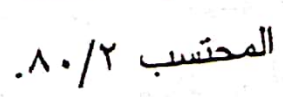




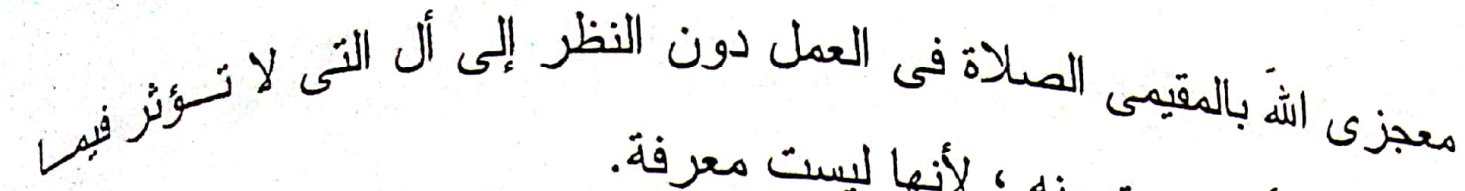
دخجزى الله بالمفيىى لـيه أو خرجت منه ؛ لأنها ليست معرفة.

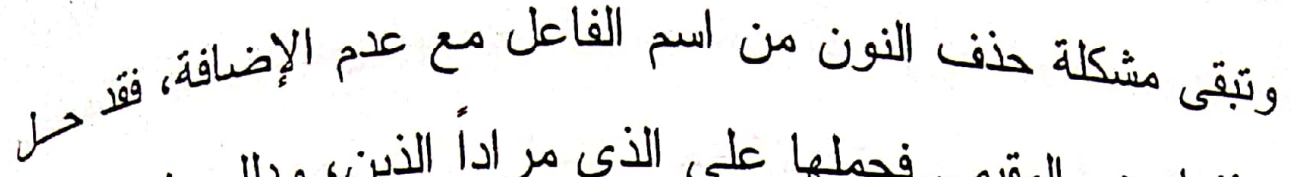
ابن جنى حذفها من و المقيمى فحملها على الذى مر ادا الذين، ودلل على ذلئل

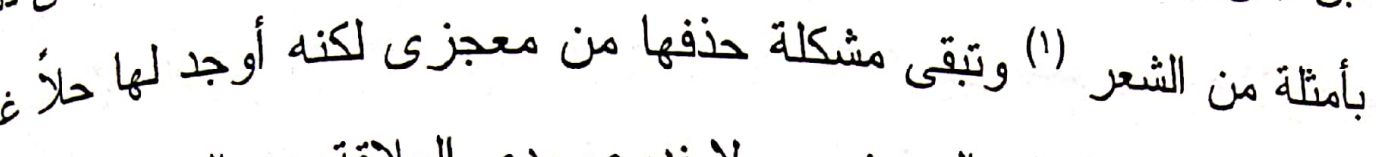
مقنع وهو حملها على المعجزى. و لا ندرى مدى العلاقةَ بين المقيمى وبين الذى

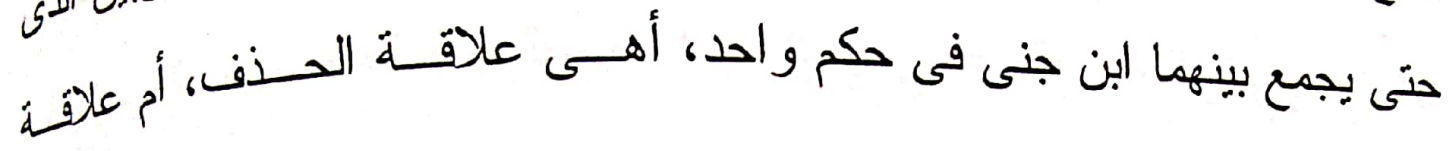

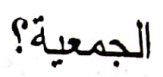

و على أية حال فالعلاقة اعتقد أنها علاقة الحذف ؛ لأن الجسامع بسبن

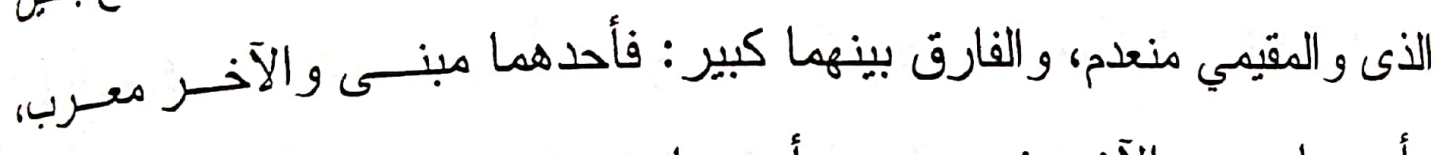
وأحدها مبهم والآخر غير مبهم، وأحدهما وصف مشتق، و الآخر لبيس كنلك...

لللك كان ابن جنى فى هذه المسألة يرسل الأحكام إرسالاً دون ضابط

$$
\text { أو سند - كما تعودنا منه - }
$$

(1) فمما ذكر ابن جنى قول الشاعر :

يأتيَهم من ور ائهم نَطَفُ

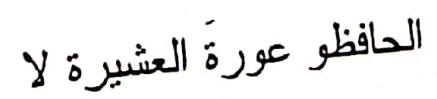

وخير الطالبي الترةٌ الغشومُ

ومما ذكره كلليل على معجزي قول الشاعر:

حابسو الأنفسن عن سوء الطهع

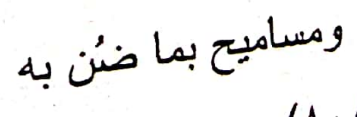

(المحتسب r/r) 


\section{الآلية الرابعة: التفريع:}

هذه الآلية قد فر ع فيها ابن جنى من القاعدة الأصلية أحكامسنا فرعيسة

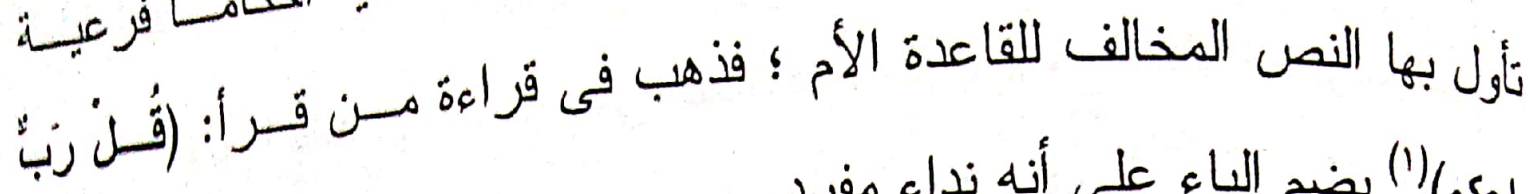
المد)|" بضم الباء على أنه نداء مفرد.

عند نداء اسم فيه الألف و اللام لابد أن ينادى بواسطة أي أو أية، نحو : الرجل والفتاة، فتقول: يا أيها الرجل، ويا أيتها الفتاة، أو ثقل: عند نداء أى وأيسنة فلا بل من وصفهما باسم معرف بأل (الجنـسية ونـصير بعـد النـداء للحهـد الحضورى)، أو بموصول، أو باسم إشارة مجرد من كاف الخطاب، فنقول: يــا

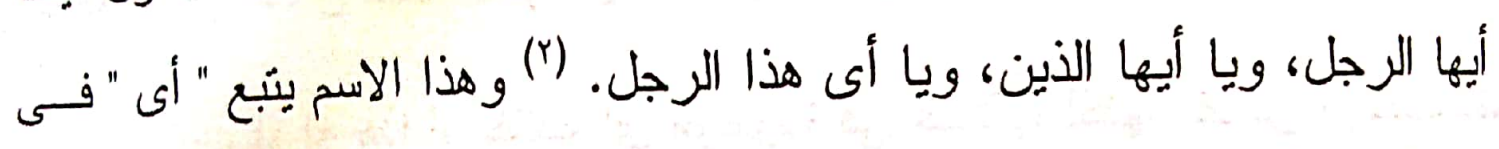
ضبطه مر اعاة للفظها.

فربُ فى القر اعة منادى حذفت منه يا، فحذفها فى الـنص لـيس مسن المواضع التى بمتنع حذفها (r)هذا هو المقرر عند النحاة لكن ابن جنى في هـــا

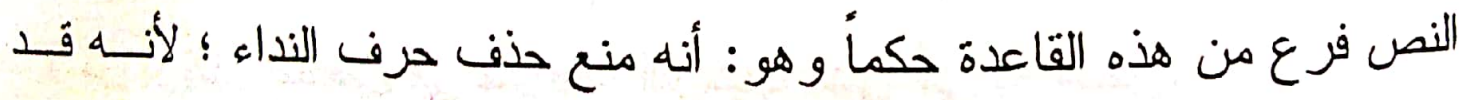

$$
\text { سورة الأنبياء: من الآية (Y II))، وهى قر اءة أبى جعفر (المحتسب 79/Y) }
$$

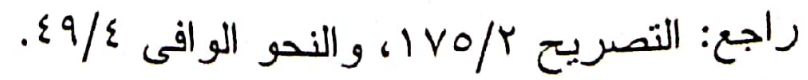

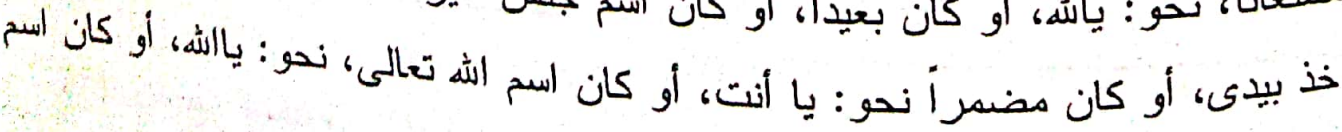

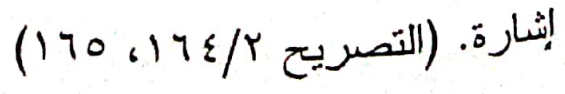




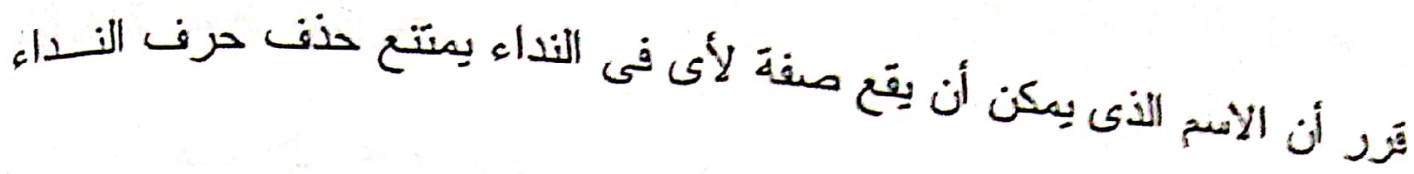
(1) إذا نودى ان وقد اعتمد فى حكمه على الصناعة، فلم يرد فى كلام العـرب نحسو:

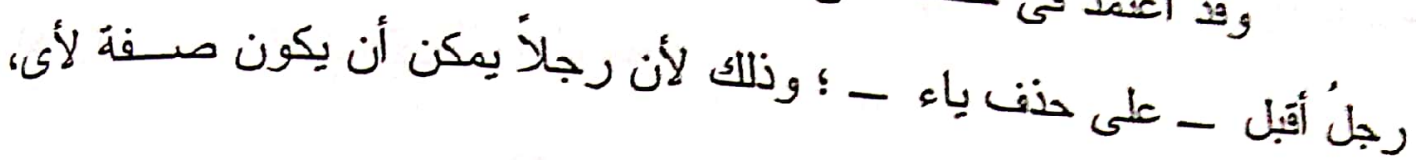

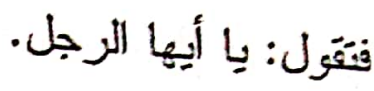
وقاس منع الحذف فى هذا النص على منع حذفه من اسم الإشارة حبث. إن المم الإشارة يكون صفة لأى فى النداء ؛ لذلك وجود حذفين كــان ممنوعـأ عندهم، وفى النص حذن الموصوف - و هو أى - وحذف حرف النداء. ويسلم له هذا لو كاتت أى موجودة فى الكلام، لكنها غيـر موجـودة،

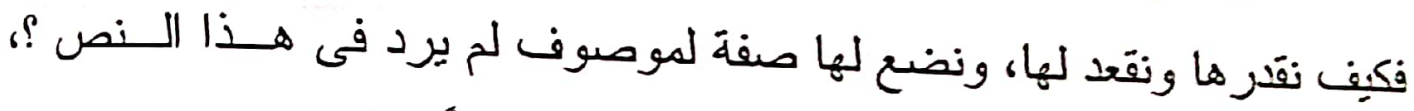
و إن كان وجودها مع وصفها فى تراكيب أخرى وارداً؛ لأن التقعيد يؤخذ مسن النص الموجود، ومن قَيام الوظائف النحوية ببيان العلائق بين نز اكيبه المتعددة، وجية لا من تزكيب يِستعمل فى منل هذا التركيب الذى أتى به النص.

وبالتالى ينتفى اجتماع الحذفين على شُئ واحد لسبب بسيط و هو عـلم وجود المحذون أصلاً فى التركيب.

$$
\begin{aligned}
& \text { راجع: المحتسب 19/r. }
\end{aligned}
$$

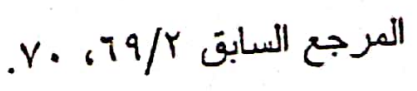


ويشفع لا بن جنى توسيع التظظير عنده حتى ثنطرد الفاعدما فنظر منع

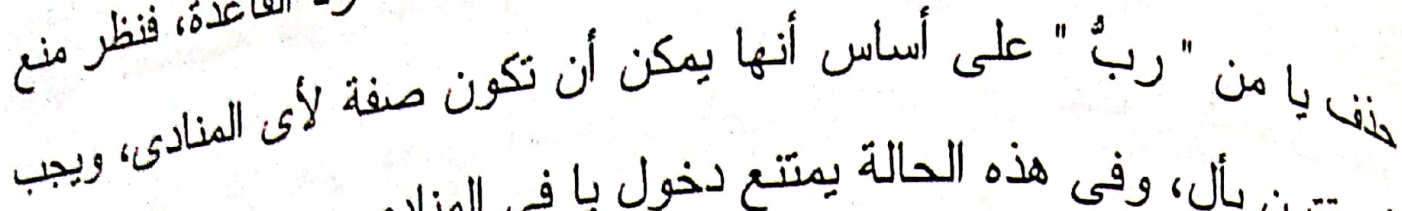
أن يقترن بأل، وفى هذه الحالة يمتتع دخول با فى المنادى.

وخرجت هذه القراءة على أنه منادى مضاف إلى باء المنكلم، وعومل

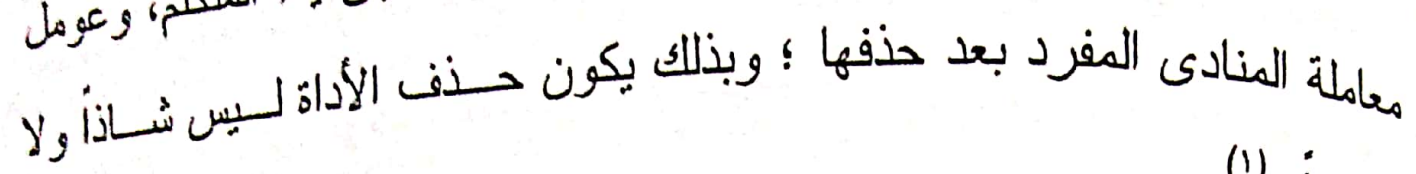

(') نينيفا. 


\section{الآلية الخامسة: طول الكلام (تكثير البنية):}

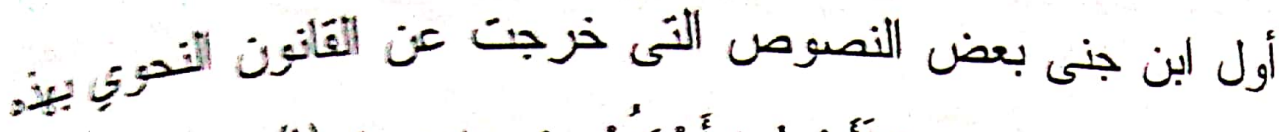

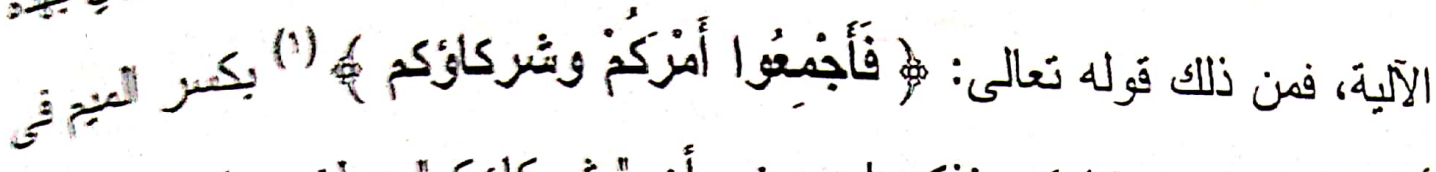
أجمعوا، ورفع شركاؤكم، فذكر ابن جنى أن " شركائكم" عطف على التسخيز فى أجمعوا من غير توكيده بضمير رفع منفصل.

فذكر ابن جنى أن ذلك جاز لطول الكلام، حيث قَزر النداة أن الطيل

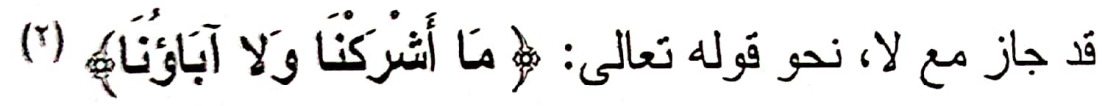

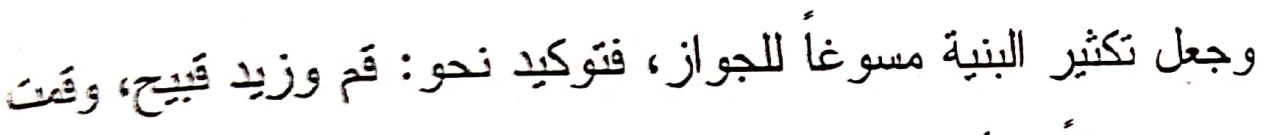

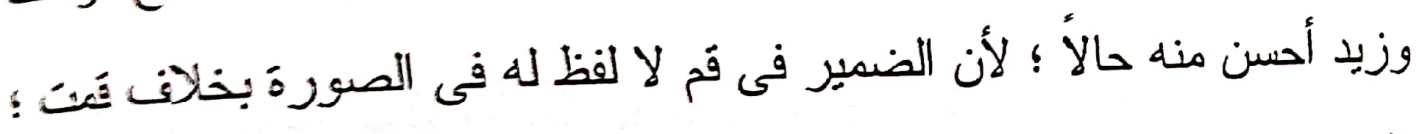

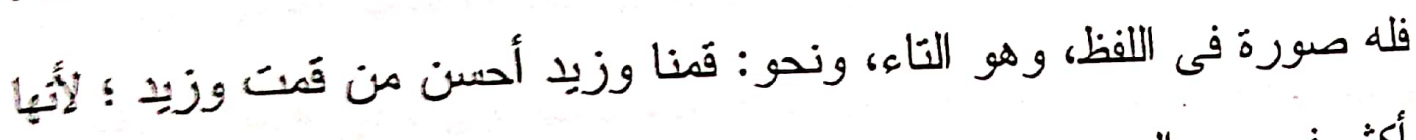

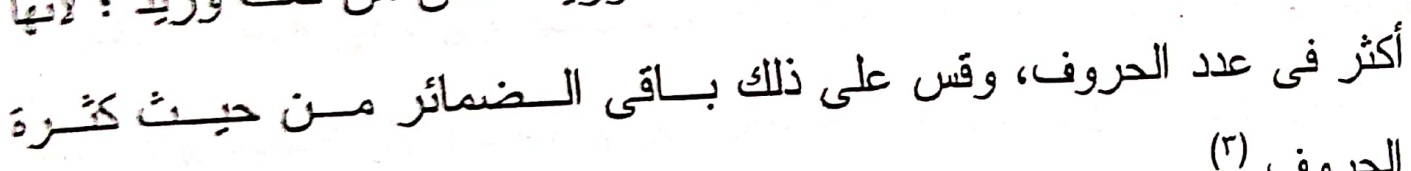

الحروف. (r) - (r)

فجملة القول منه أن الضمير المرفوع المعطوف عليه إذا كتزت حزوقها

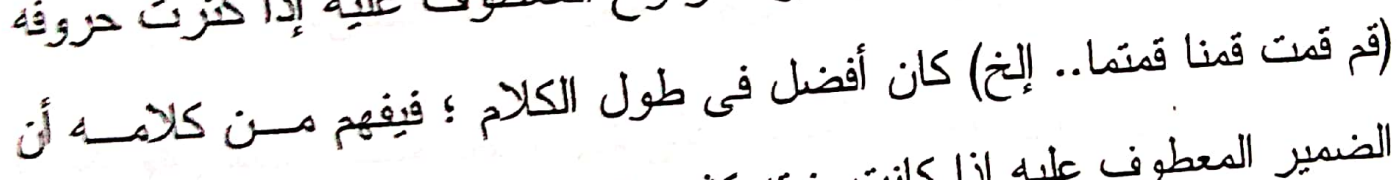

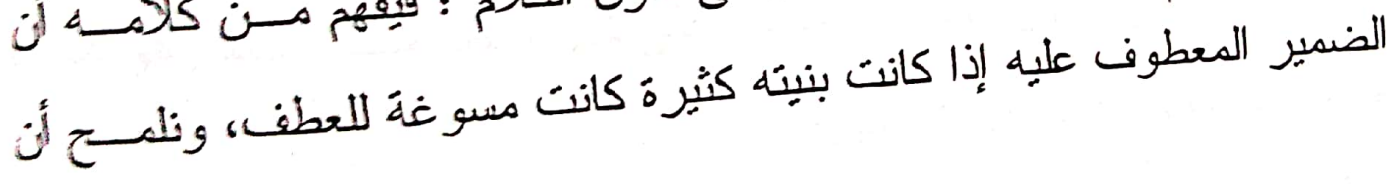

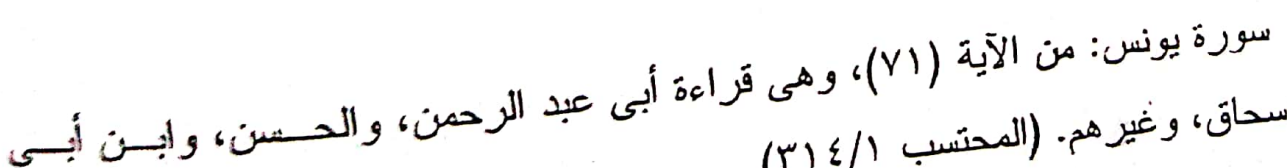

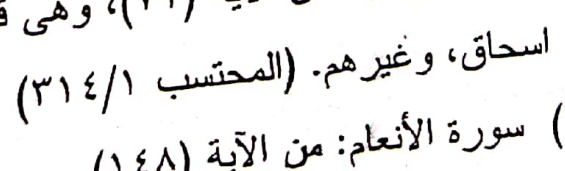




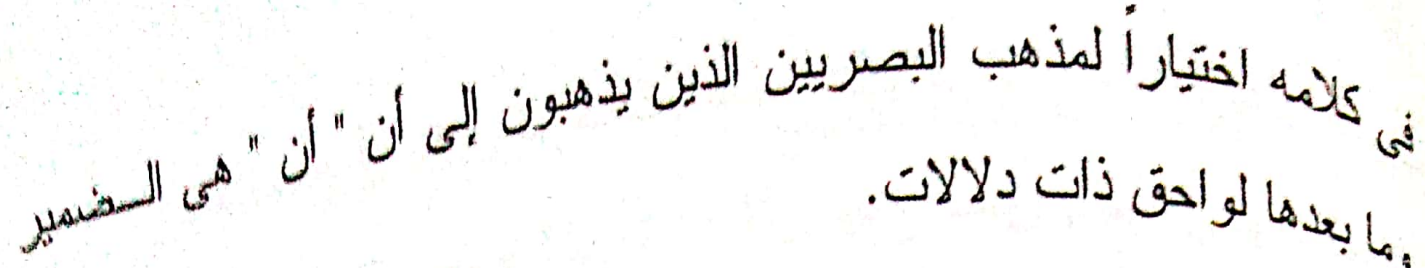

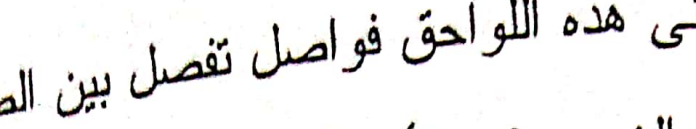

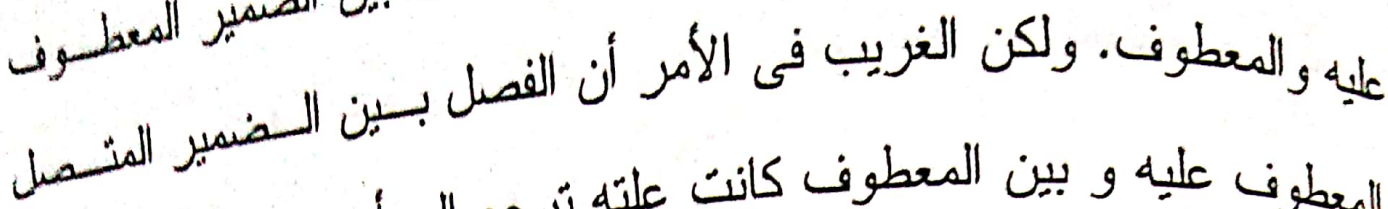

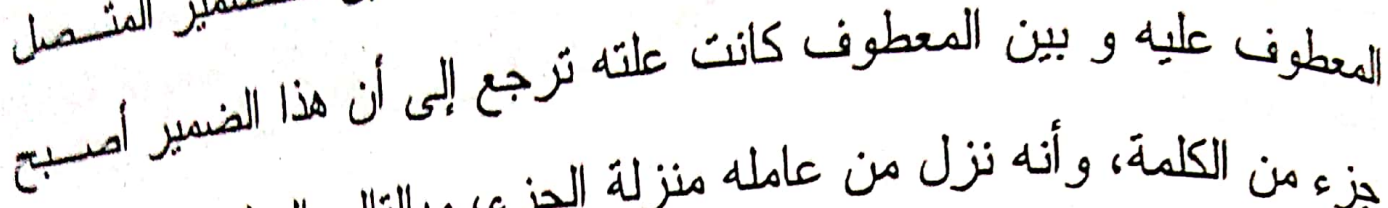

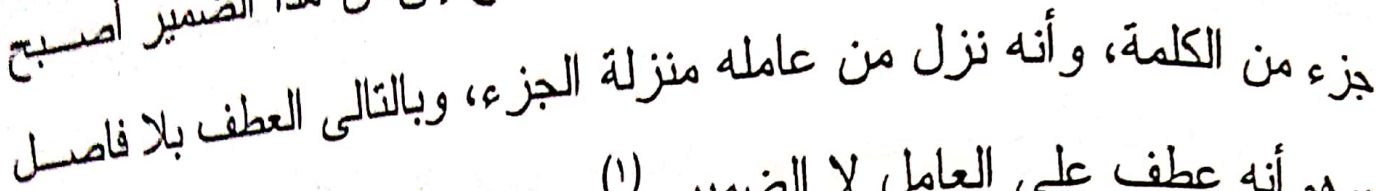

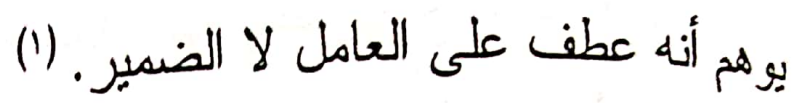

ولكن ابن جنى لم بعتذ بهذه الاعتبارية، وجعل اللواحق فو اصل حفانًا

على القاعدة، و على الأسس التى سار عليها النحاة من قبله (البصريون).

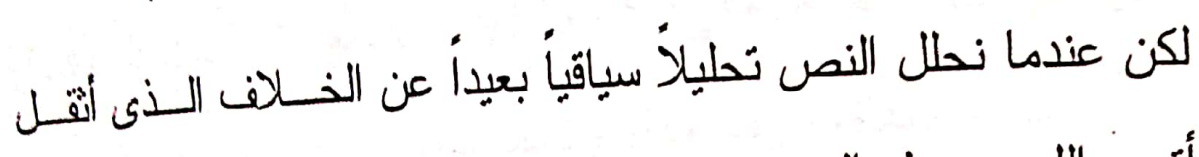

الكاهل وأتعب اللب - هل الضمير هو كذا ولا كذا - نجد أن النصب أقوى من الني

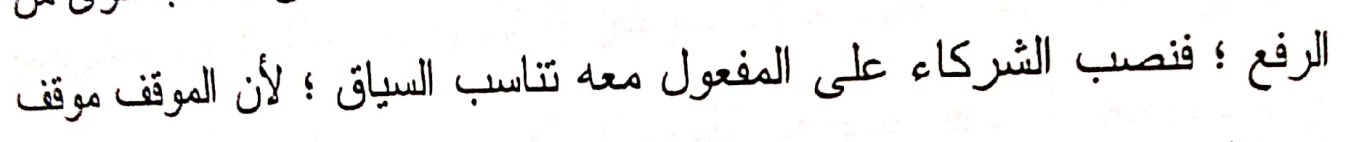

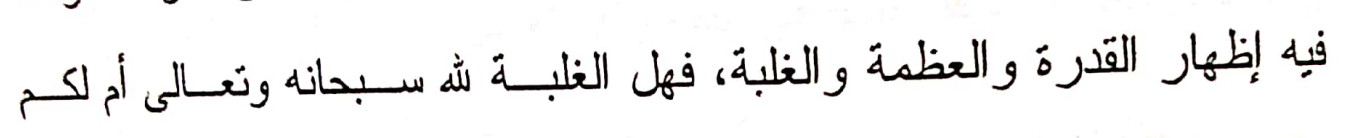

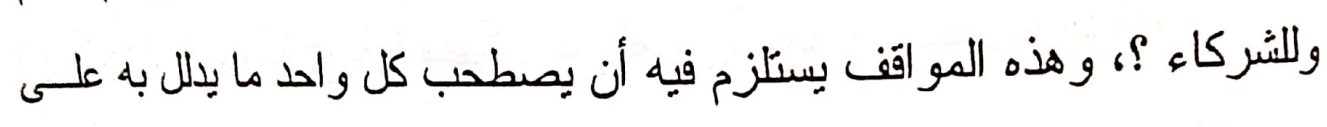

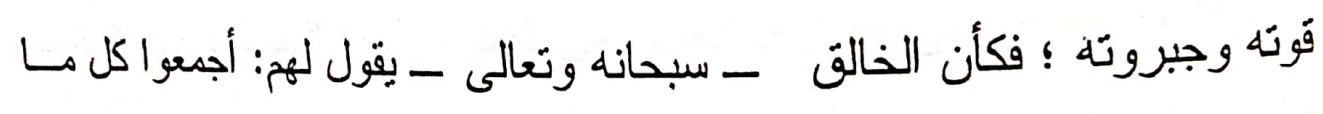

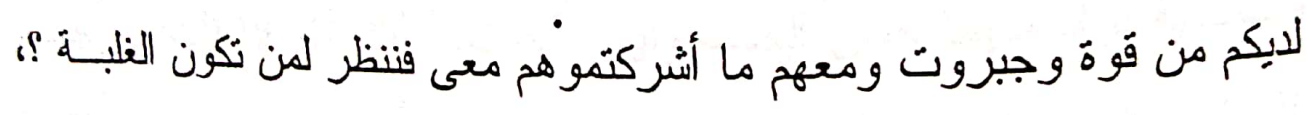

فالمعية والاصطحاب هى المناسبة للسياق.

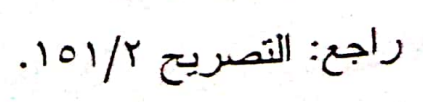


ولا يصح أن تكون شركاءكم عطفأ على أمركم ؛ لأنه لا يقال: أجهـئ ثقول: أجمعت أمرى، ولا ثقول: أجمعت الناس أو الشركاء، و إنما تقول: جمعت

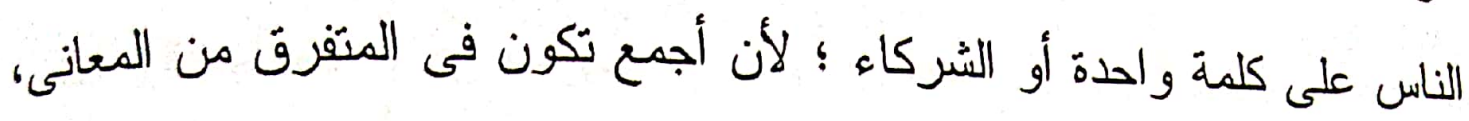
وجمع تكون فى المتفرق من الذوات. (1)

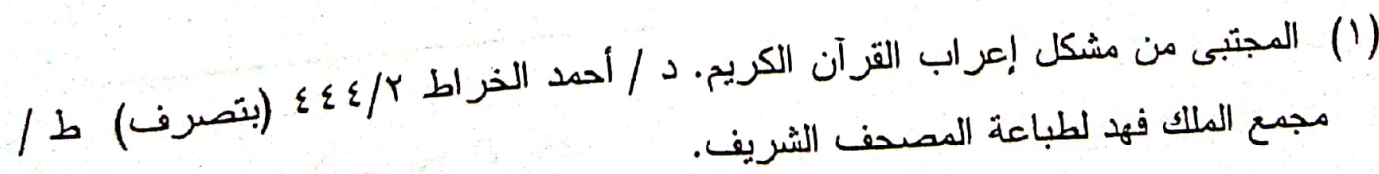

$$
\begin{aligned}
& \text { 4ा }
\end{aligned}
$$


اعتمد ابن جنى كثير أفى تأوبلاتله التى خرجت فى ظاهرها عن النظام

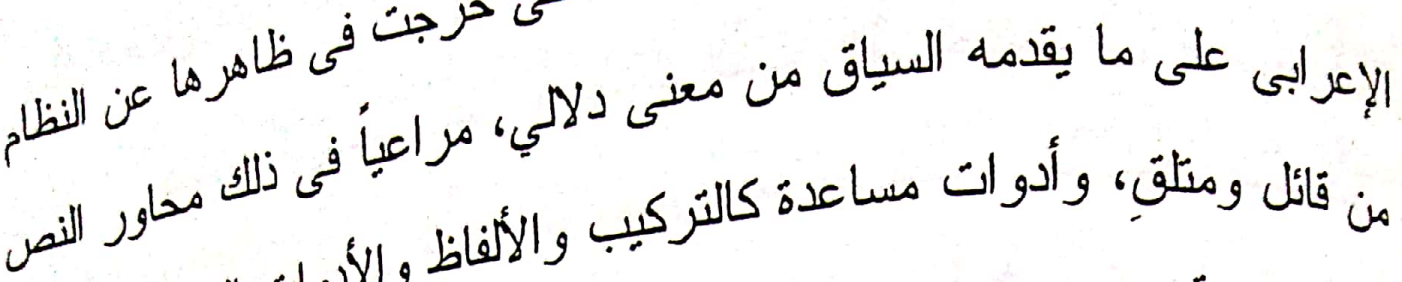

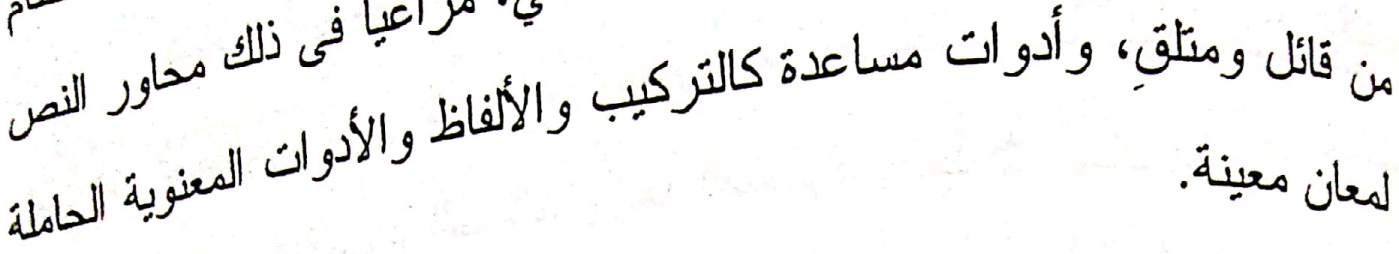

لقد استطاع ابن جنى بهذه الآليةً أن يصل إلى كلام جمبل طبب لـبسي

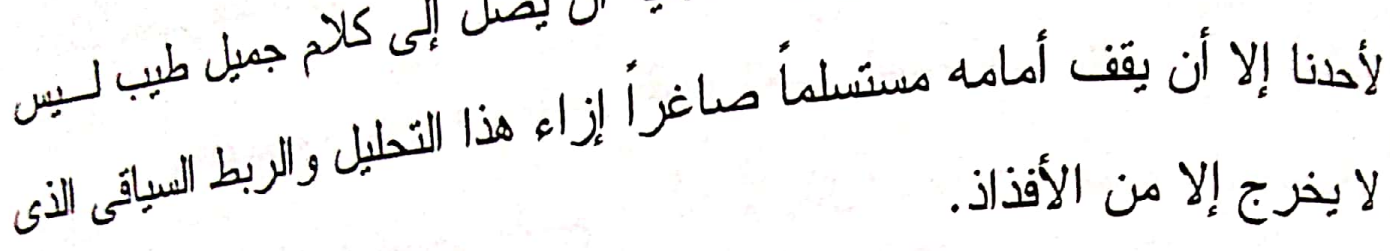
لمعان معينة.

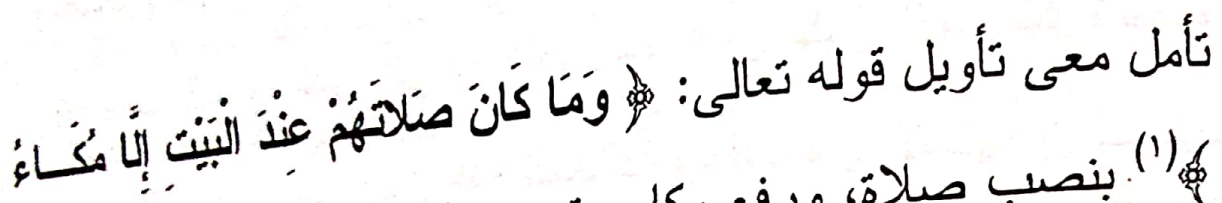

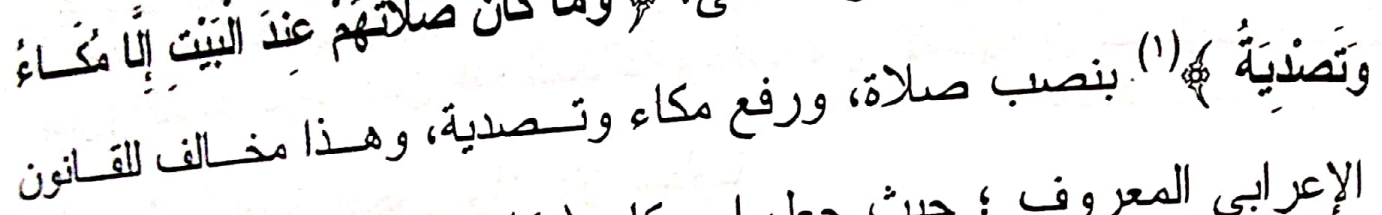

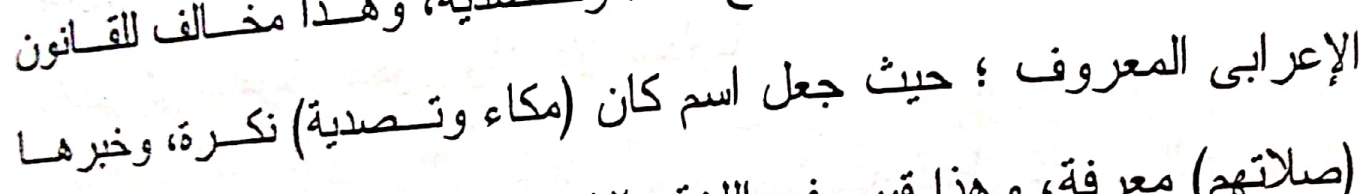
(صلاتهم) معرفة، و هذا قبيح فى اللغة والاستعمال.

فتأوله ابن جنى - بعد أن سجل عدم تأييده لوقوع الســم كسان نكـرة وخبرها معرفة - على أنه أراد الجنس من الفعل، وليس الفـل، لأن المكـاء

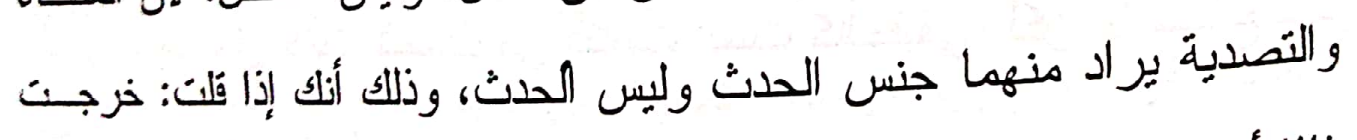
فإذا أسد بالباب، لا تربد أسداً بعينه، و إنما تريد واحدأ من الجنس. وفـى الآبــة

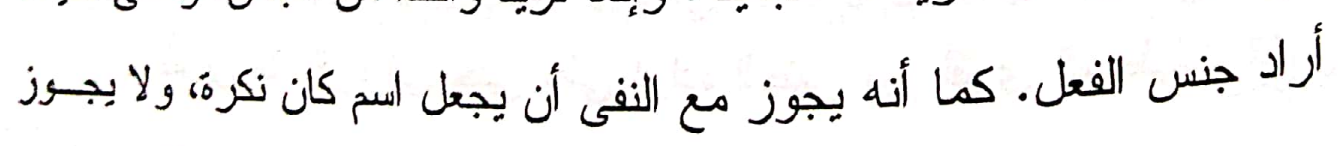

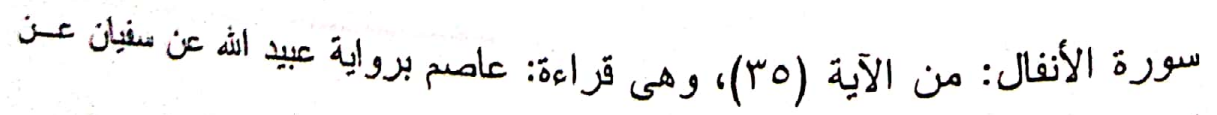

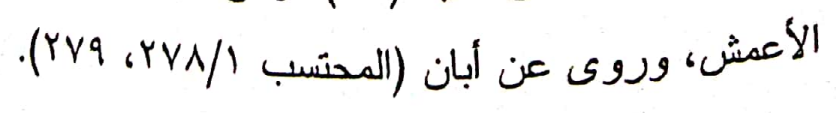


هذا مع الإيجاب، تقول: ما كان إنسان خيرأ منك، ولا تقول: كان إنسان خجران

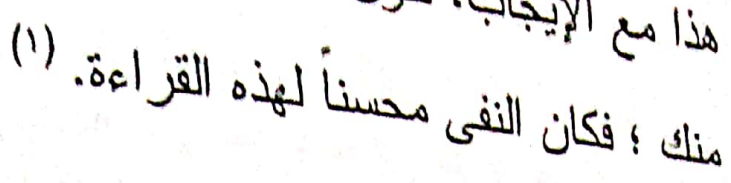
فاعتد ابن جنى على معطيات السياق النى حسنت من النص، وكلر

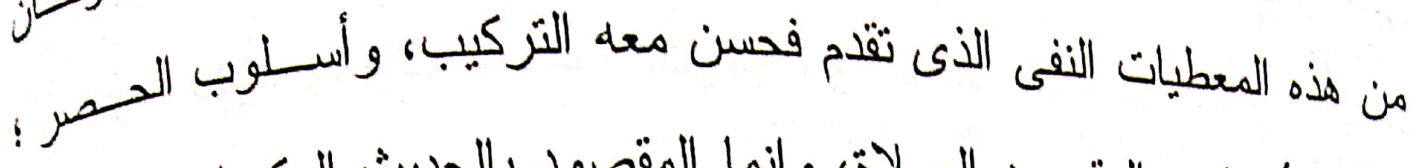
وذلك لأنه ليس المقصود الصلاة، و إنما المقصود بالحديث المكــاء والتصصلين. فلذلك حصر هما بإلا.

والثقديم والتأخير فى النص تقديم الخبر (صلاتهم) على الانس (مكلا. وتصدية) سوغ عملية التنكير للاسم ؛ لأنه لا يقال: وما كان مكاء وتسئسئ... إلخ، وهذا السياق الذي أتى به النص سوغ أن يكون الاسم نكرة لبعده عن عامله (كان) فالتباعد بينهما حسن هذه المخالفة وخفف من الاستهجان للتركيب، وعساد بالنص إلى الناموس النحوى وإن كان متفاوناً.

ومن معطيات السياق التأنيث الذى خلا منه الفعل كان، و الذى حسن ؛

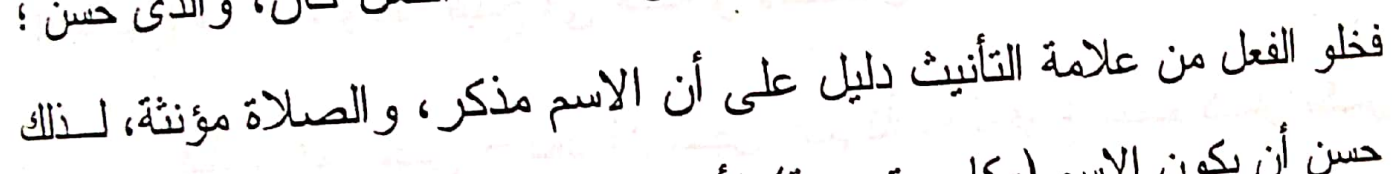

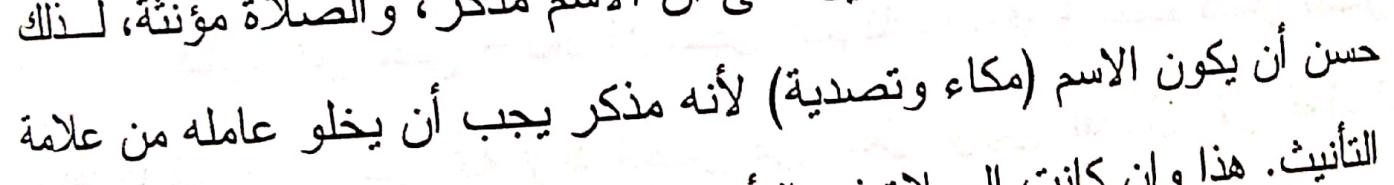

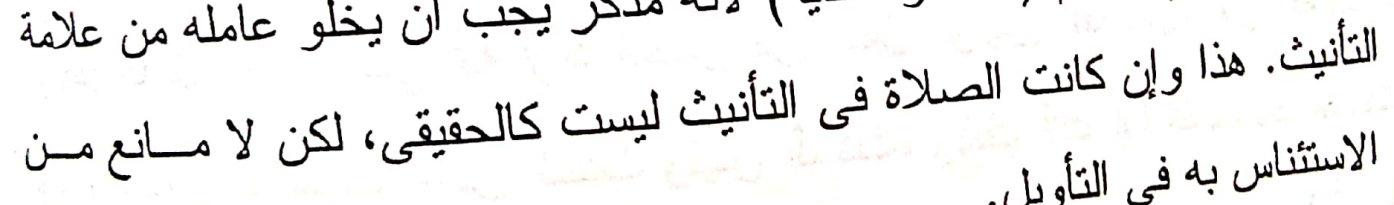
الاستناس به فى التأويل.

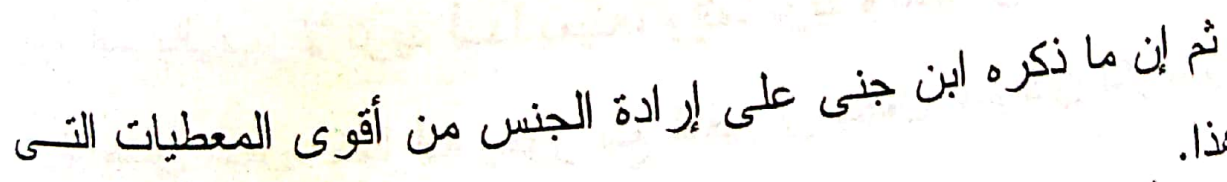
سوغت هذا. 
أذف إلى ذلك أن السياق و المقام الذي ورد فيه النص هـو نـصفير

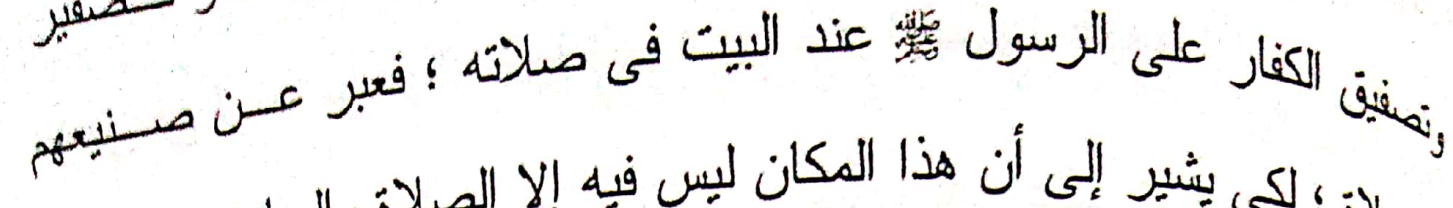
بالهالاة ؛ لكى يشير إلى أن هذا المكان ليس فيه إلا الصلاة والعبادة ؛ لذلك جاء اليبات على نمط فعلهم فأسند الصلاة - صلاتهم - إلى المكاء والتصدية ؛ فكان

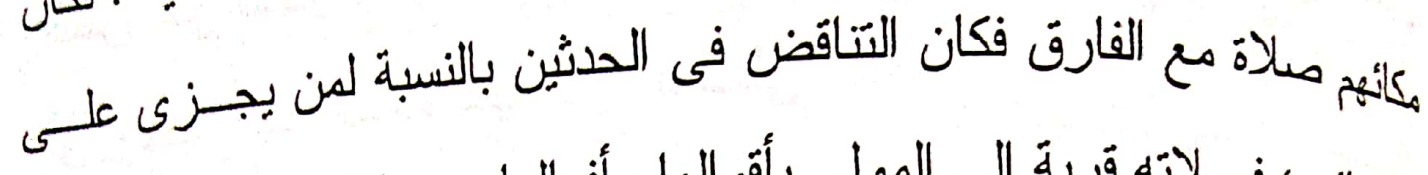
الهنائع ؛ فصلاته قربة إلى المولى بأقو الها و أفعالها، وصلاتهم فى مكان الصلاة بدأ عن المولى و التى من أفعالها المكاء و التصدية، فعبر بالصلاة نظرأ للمكان وأراد الأحداث التى وقعت من البشر فى هذا الدكان سواء أكانت قربة له نعالى لهي أم إعراضأ وكفرأ. فكأن المعنى - و الله أعلم - كان المكاء والتصدية فى مكسان

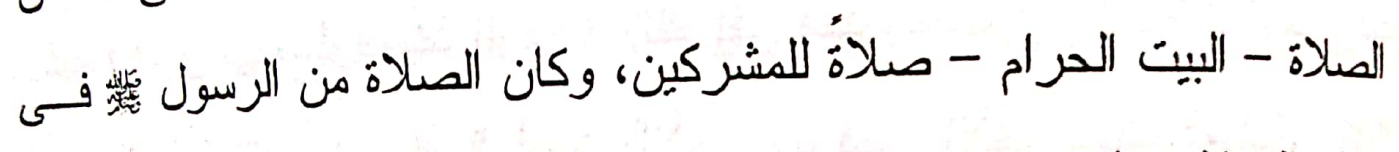
مكان الصلاة عبادة.

ومما يؤيد ذلك - أيضاً - أن القرآن خاطبهم على قدر عقولهم ونـزل

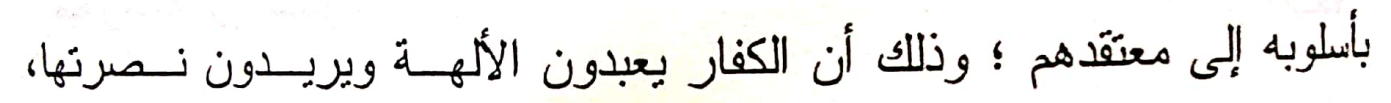

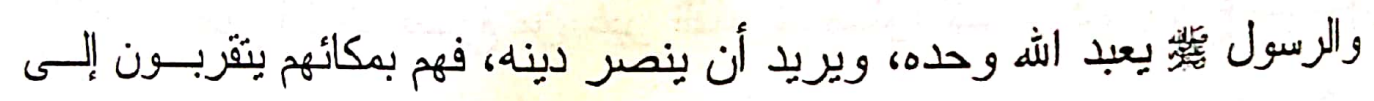

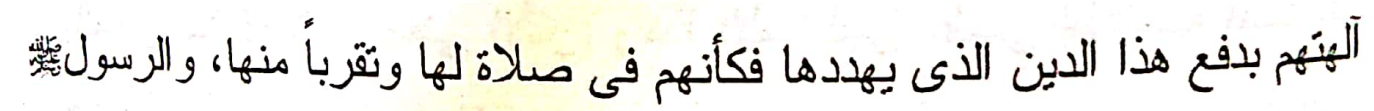
بصلاته يتثرب إلى ربه ويعبده ؛ فالمر اد من النص الأحداث وليست المعـانى، بعنى كان المكاء صنيعهم قربة للآلهة وصنلاة، وكانت الصلاة صنيع المسؤمنين صُربة لله. 
ومما ذكره ابن جنى فى تأويله معتمداً على السياق ومعطبانسه فولي.

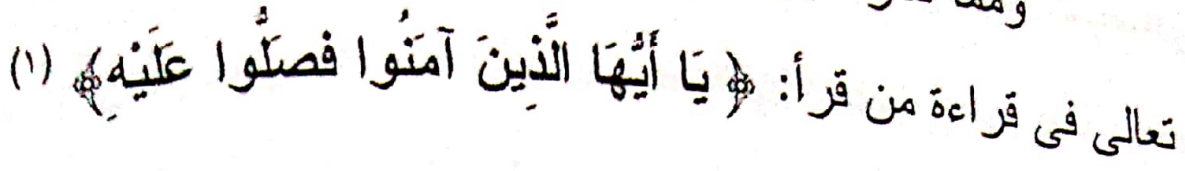

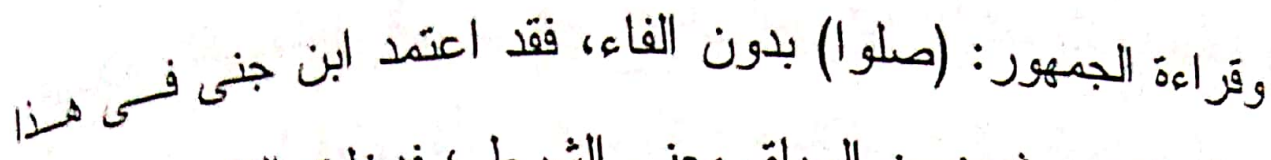

النص على السياق، حيث ضمن السياق معنى الشرط ؛ فذخلت الفاء في الفنـل. أى: وجب علينا الصلاة عليه لأن الله صلى عليه.

فهذا النص نظيِر قول العربى: قد أعطيتك فخذ، فوجب عليك الأخذ من

أجل العطية، إلا أن حذف الفاء من مثل هذا أقوى معنى. (r)

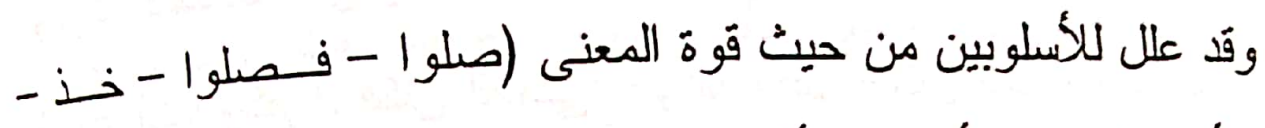

فذذ) فقرر أن صلوا وخذ أقوى ؛ لأنك (فى فذذ وفصلوا) إذا جعلت الأخذ واجبا

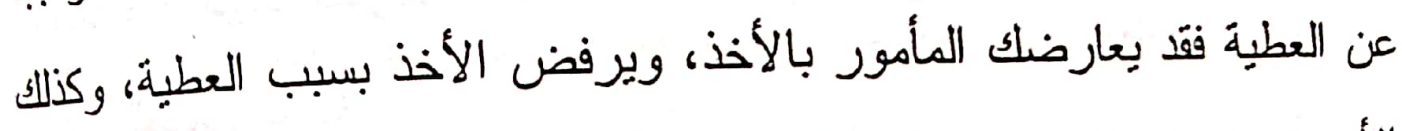

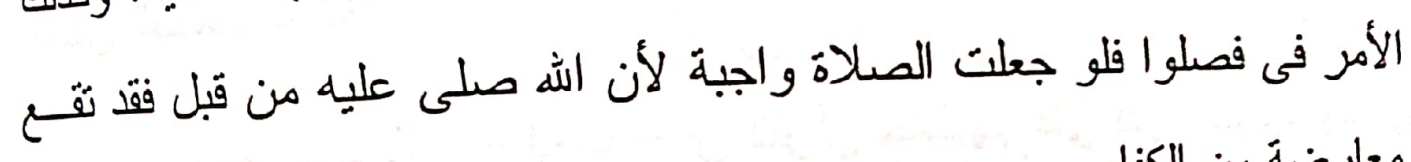
معارضة من الكفار.

أما إذا قَلِت الصيخ من غير الفاء ـ صلوا خذ ـ فلم بسر ع المـأمور

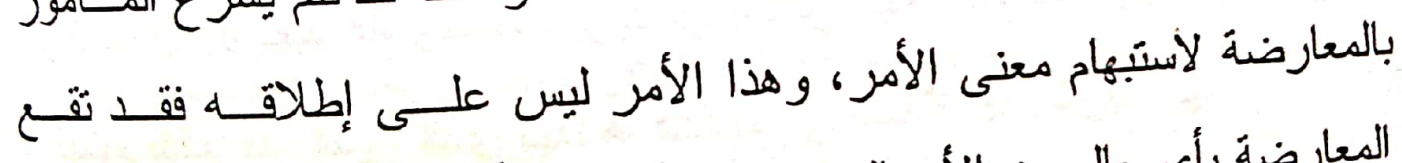

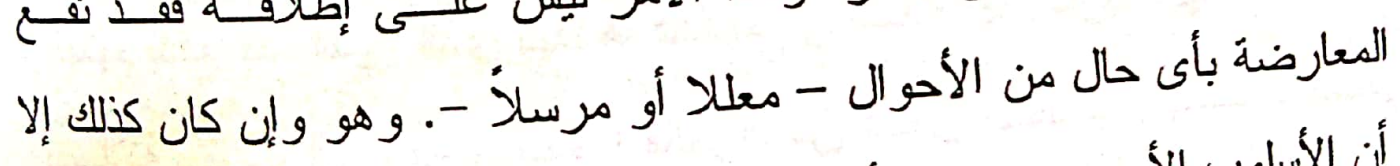

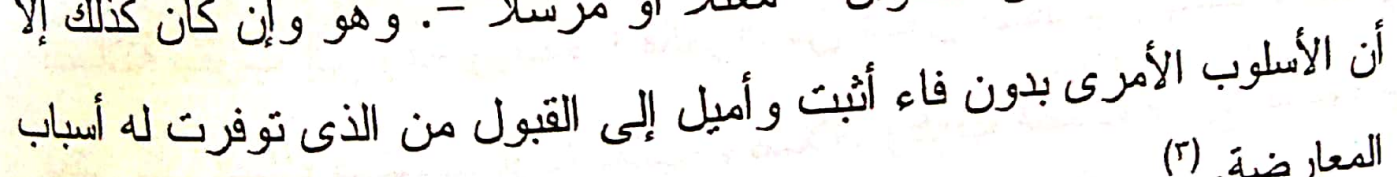
المعارضة.

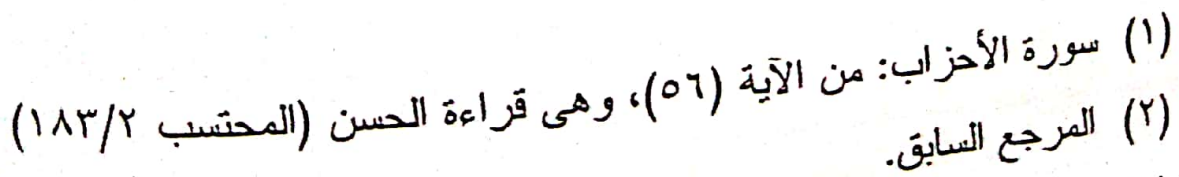

$$
\begin{aligned}
& \text { المرجع السابق. }
\end{aligned}
$$

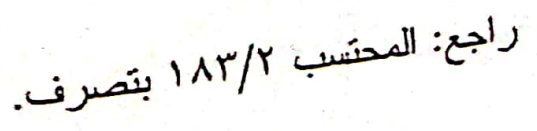




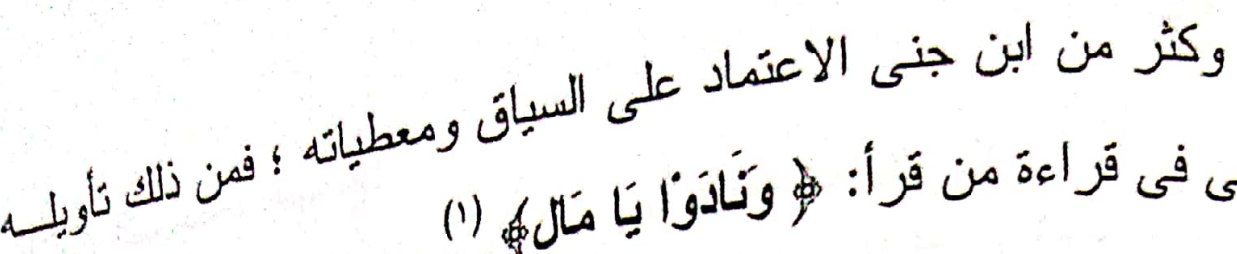

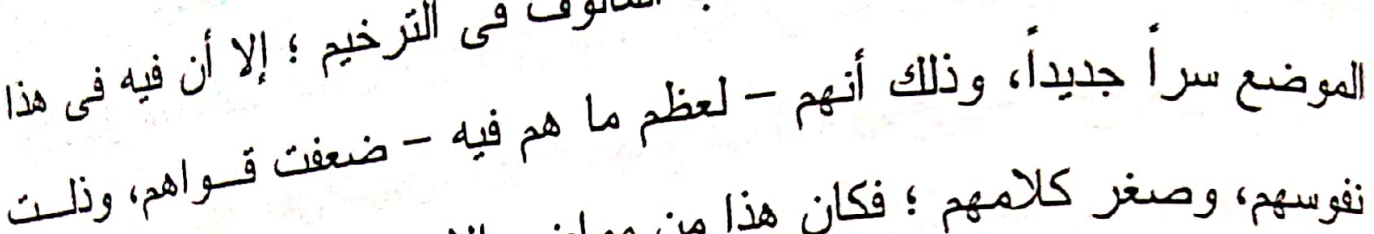

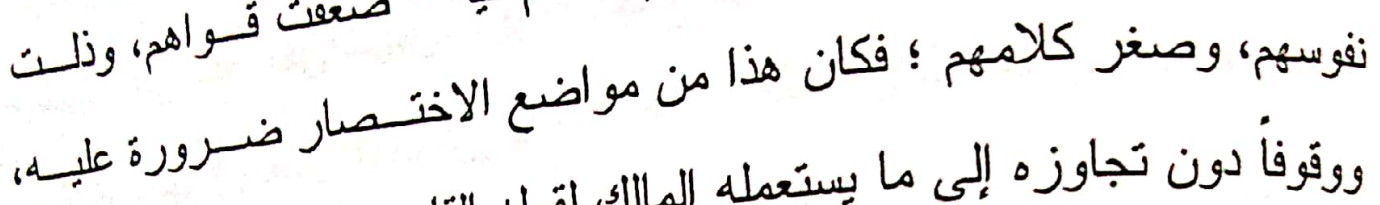

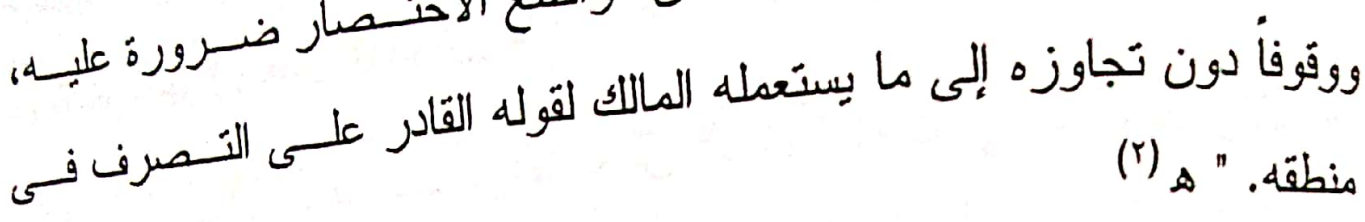

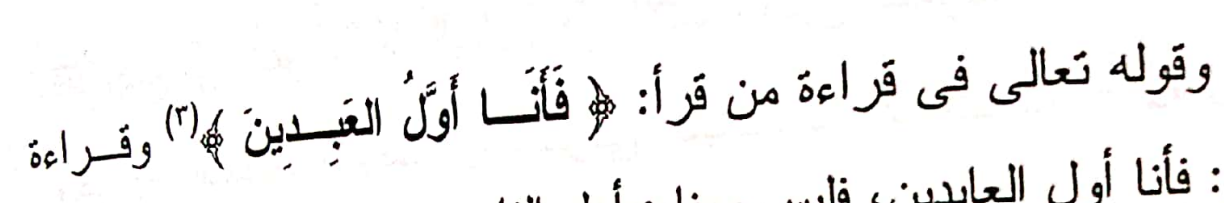

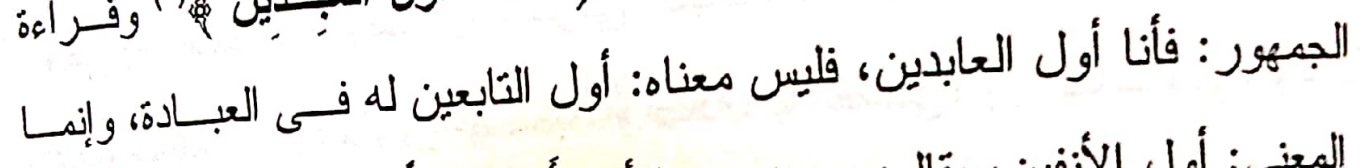

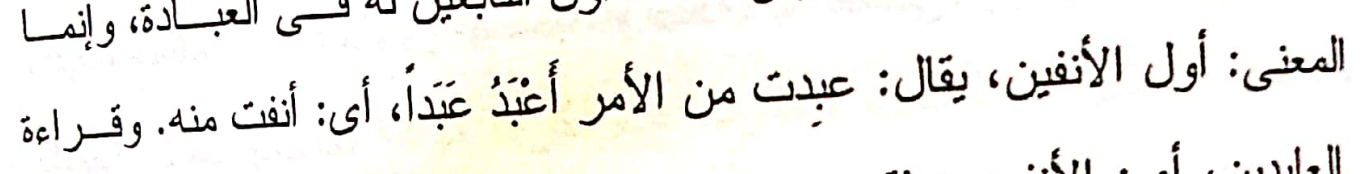

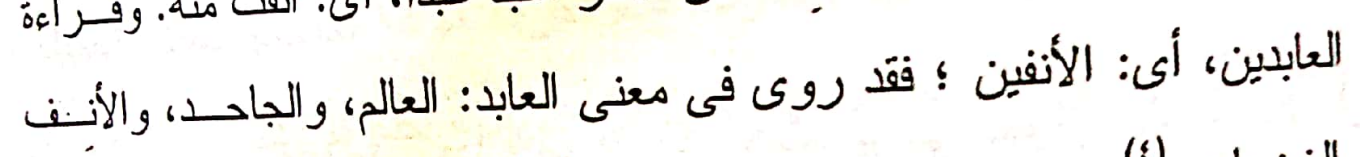

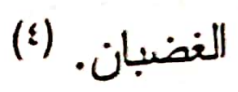

$$
\begin{aligned}
& \text { سورة الزخرن: من الآية (YV)، ونسبت إلى الإمام على (المحنب roy/r). }
\end{aligned}
$$

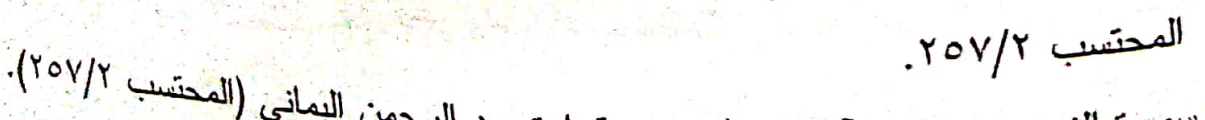

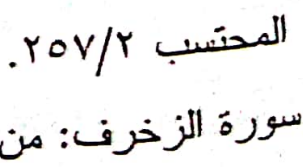

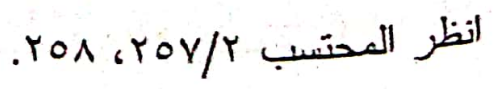




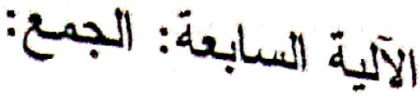

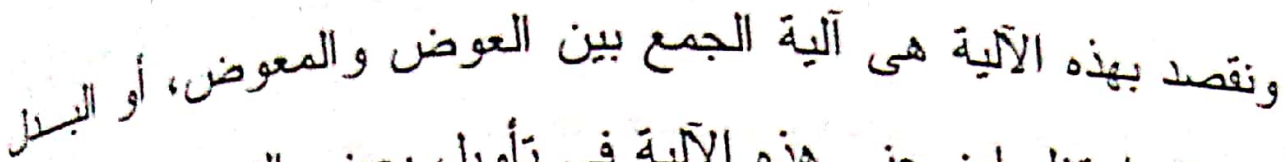

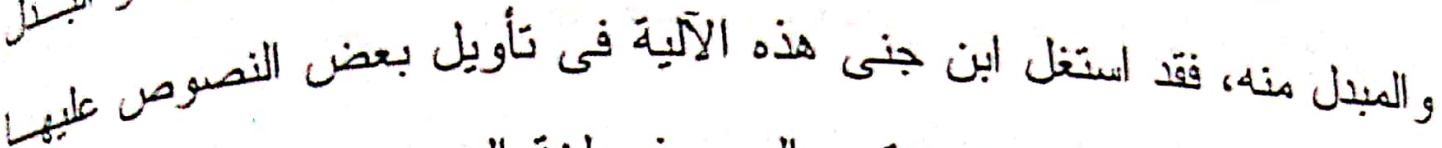
مستـأ فى ذلاك على شيئين: وفَوع الجمع فى لغة العرب - و وإن كسان نسائراً. والآخر : جواز بعض النحويِين له.

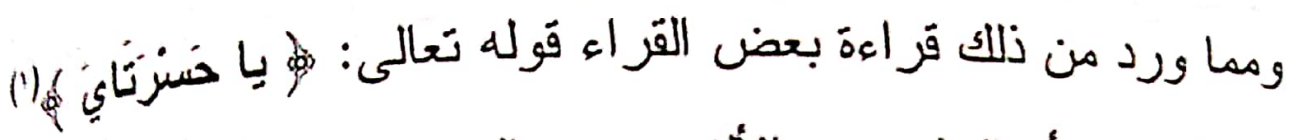

فقه جمع بين العوض أو البدل وهى الألف، وبين المعوض منه أو المبلل منسه

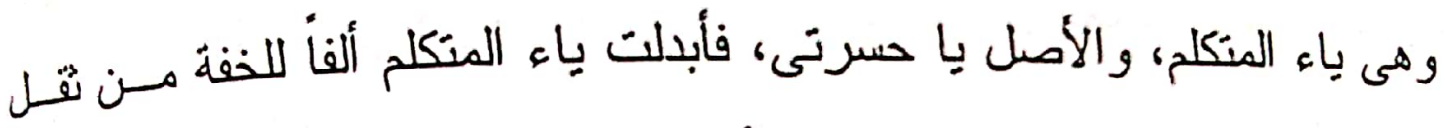

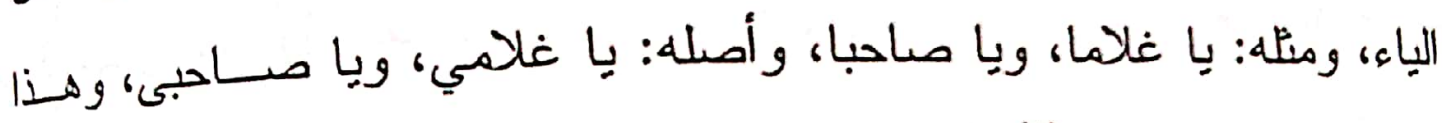

الإبدال خاص بالنداء. (r)

فتأول ابن جنى هذا النص، وذكر كلاماً يوحى بجواز الأمر، فنكر أن

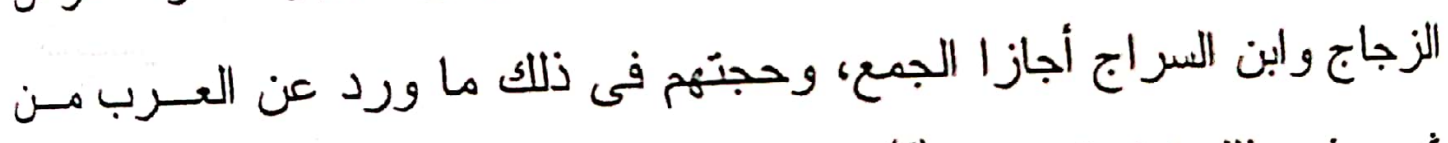

شعر ، فمن ذلك قُول الشُاعر : (r)

هما نفتا فى في" فمويهما على النابح العاوى أثند رجام قفة جمع الثُاعر بين الميّم - البدل - و الواو - المبلدل منه فى قوله: فمويهما.

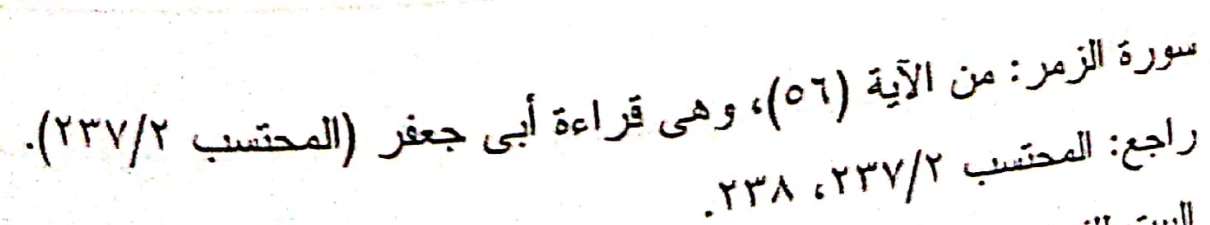

(r)

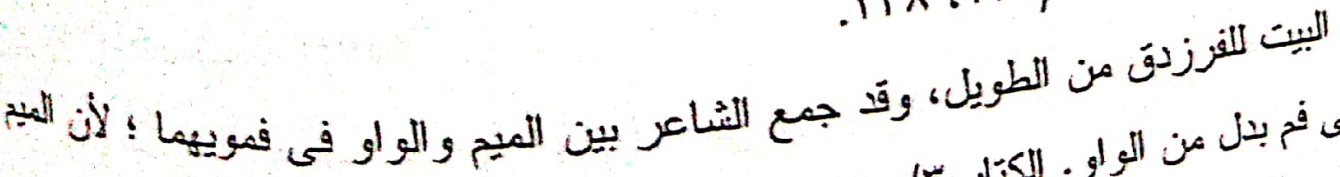

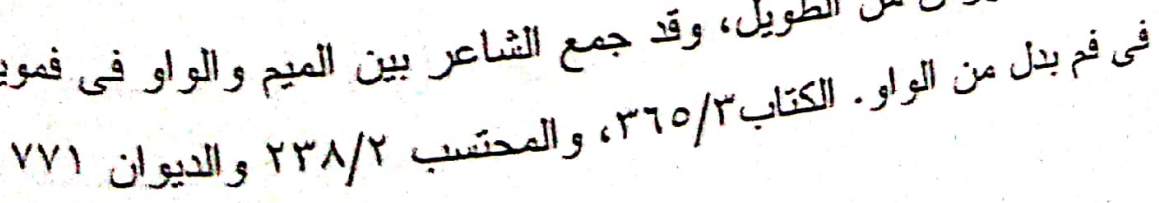


وقول الآخر: (1)

إنى إذا ما حدث ألما دعوت يا اللهم يا اللهها

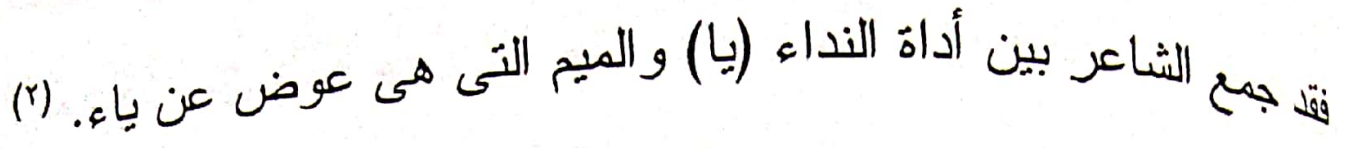
وما ساقه ابن جنى وغيره اقتصر على الشعر، ومن المعروف أن لغة الشعر تختلف عن لغة النثر ؛ فلغة الشعر تتصب فى قو الب معبينة يحكما الثقيل بنظام يخضع للوزن، ونظام معين فى اختيار التز اكيب التى توافق الشعور، وهذا التحمى فى لغة الشعر قد يضطر معه لارتكاب خرقات ومحظورات حتى يحقـنق الغرض من اللغة.

هذا بالإضافة إلى ما سيق من آليات أشرت إليها فى نمهيد هذا البحث، وقل ذكرها كثير من العلماء ؛ فآثرت عدم ذكرها خوف الحشو والإطالة، وهناك بعض الأشياء التى استخدمها ابن جنى فى تأويلاته لكنه لم يكثر من الاعتمساد

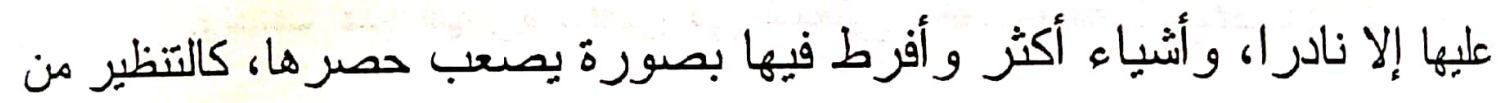
الشُر على ما يذكر، والارتكاز على الأصول البصرية، ورد النص إلى قانونه بعقلانية فائقة مستخدماً فى ذلك المنطق. و أنا أشير إلى ما قل عنده، و اعتمد عليه فى تأويلاته.

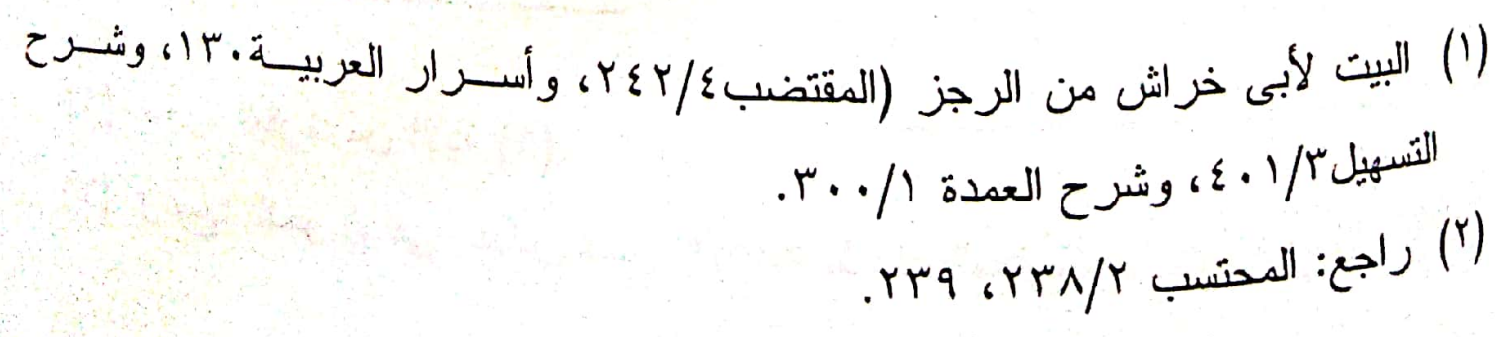




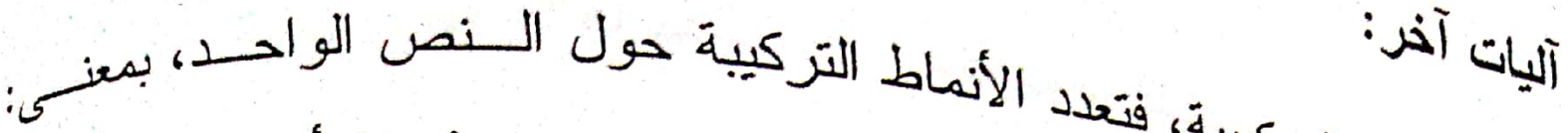

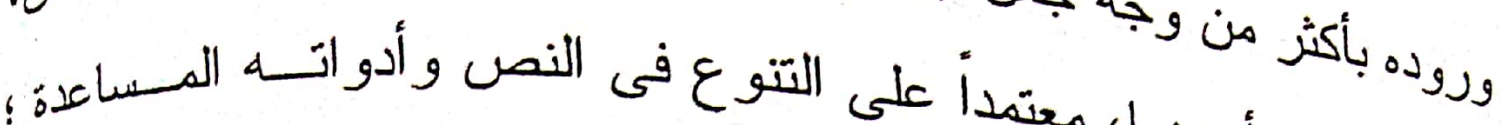

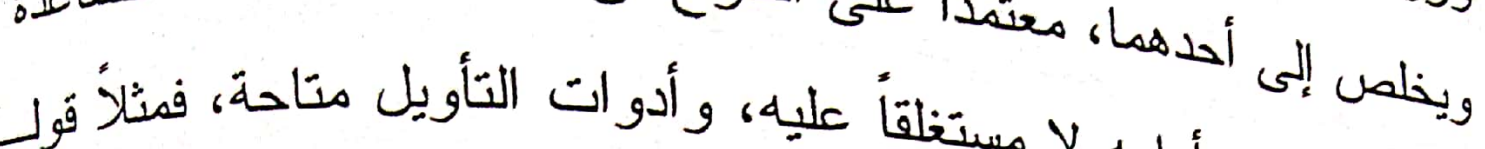

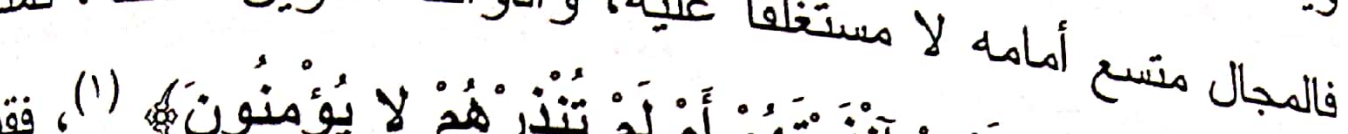

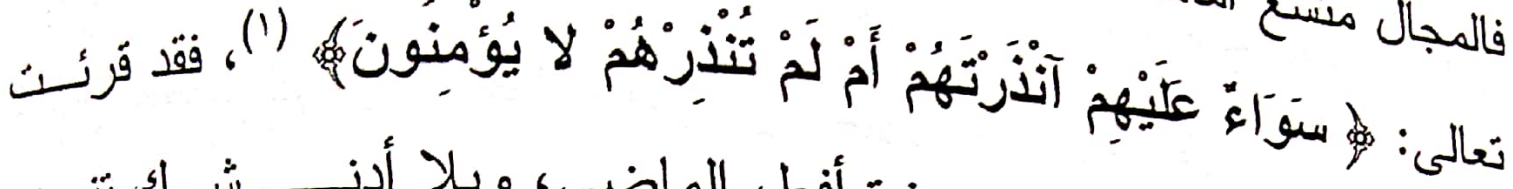

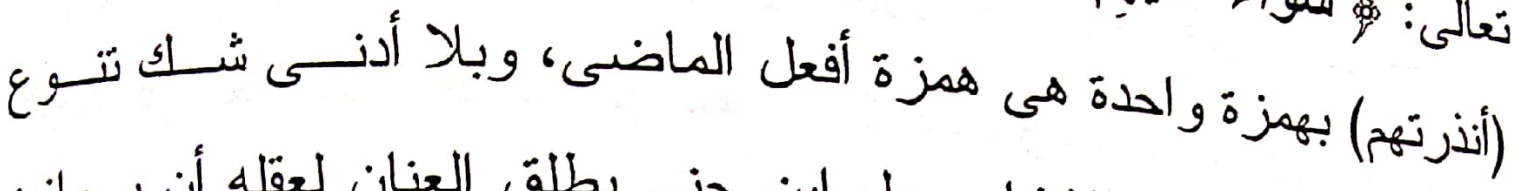
التركيب بين الخبر والإنشاء جعل ابن جنى يطلق العنان لعقله أن بــوازن بين التركبين، وكانت أدواته المساعدة لتفضيل تركيب (آنذرنهم) وجود أم، وأيضاً السياق يتطلب وجود همزة التسوية فالتسوية مستفادة من المصدر -

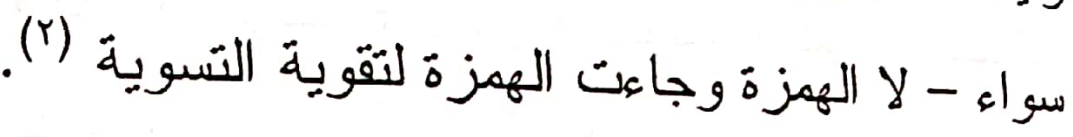
وحذف هذه الهزةة ينقص فى المعنى و الصناعة ؛ فإنفصاها المعنى أن استواء الإنذار وعدمه عند الكفار حدث غير مدلول عليه بزمن، وبالتالى يـلـ

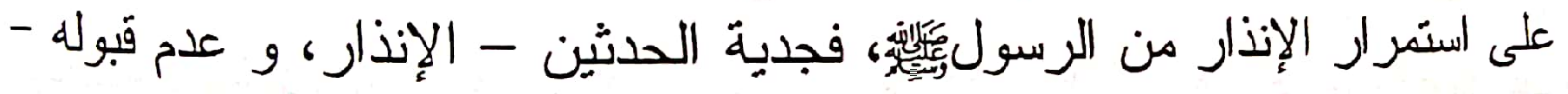
بناسبها الاستو اء باللفظ وبالعوامل المساعدة كالهمزة، و أيضاً خلو الفعل الماضىى من هذه الهمزة يصور توقف الإنذار إلى زمن التكلم، وأن الإنذار لا ينفع مهـ 
هؤ لاء، على الرغم بأن الرسولئق مكلف بالإنذار طيلة حِيائه، و إنما المعنى: أنه لا يجهة نفسه مع هؤ لاء.

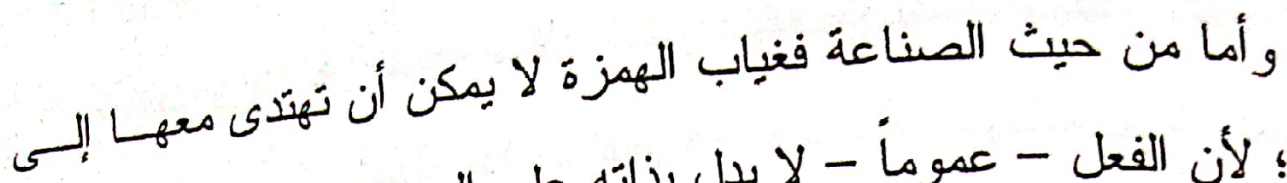

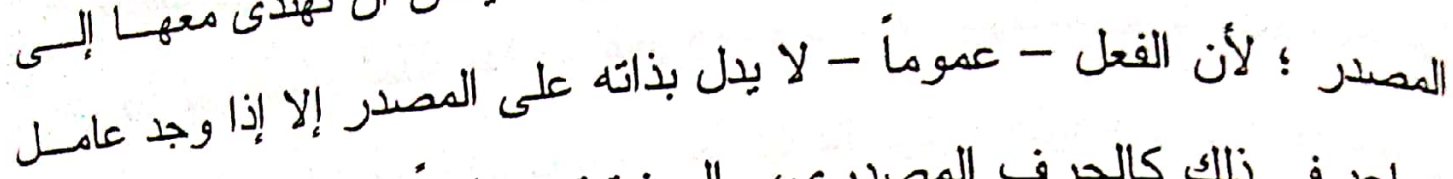
مساعد فى ذلك كالحرف المصدرى، و الهمزة تعد عاملاً مسساعدأ فـى عمليسـة السبك.

أضف إلى الخلل البنوى فى الجملة - و إن كان حذف الهمزة قُ خفف

من اجتماع النظائر فى الشكل - إلا أن البنية قد نغير نمطها و أدو اتها التى تبنى

$$
\text { عليها - كالمصدر سواء، و الهمزة، وأم -. }
$$

لكن مع ذلك استطاع ابن جنى أن يستغل هذا النمط التركيبـى الـــى بمكن أن يكون غير غالب فى لغة العرب، ويفترض وجود الهمزة فى الـذهن، ولنقل وجودها فى اللفظ حذقت.

وقد استخدم ببر اعة فائقة التتوع و المزواجة بين الأســاليب المنـــدة،

كالذبر والإنشاء، ولذلك رفض حذف همزة أفعل الماضى (') واعتقد أن ســبب الرفض لهذا التنوع الخفى ـــواله أعلم -..

التضمين: هذه الآلية أكثر منها ابن جنى و غيره كثرة مفرطة ؛ لارجبة لا لأل يصعب حصر ها، و أنا أكتفى بنص لابن جنى يدل على ما ذكرنا، فنص فى هي الئ

راجع: المحتسب /1/ 0.01، 01 


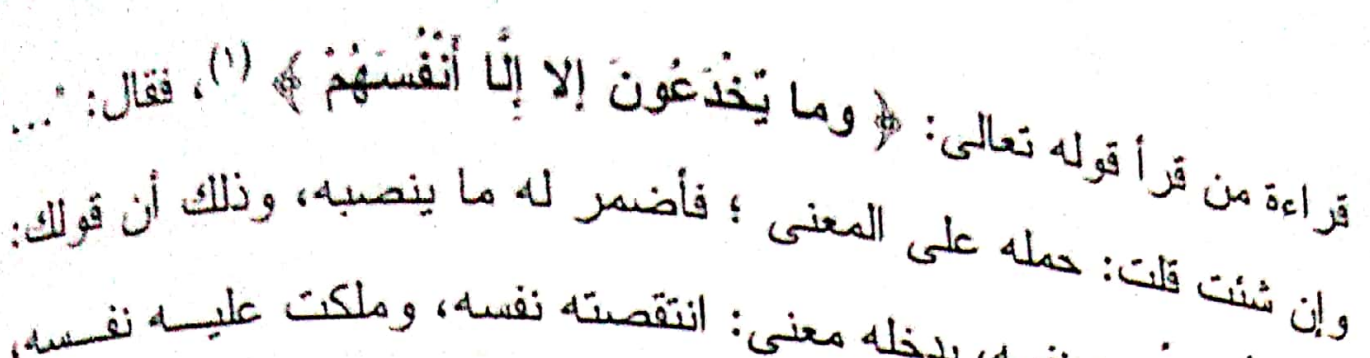

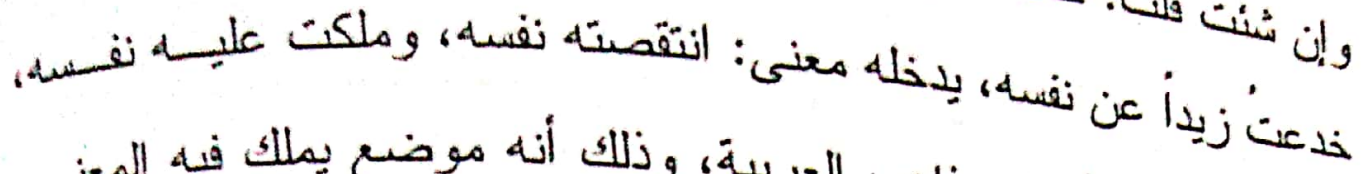

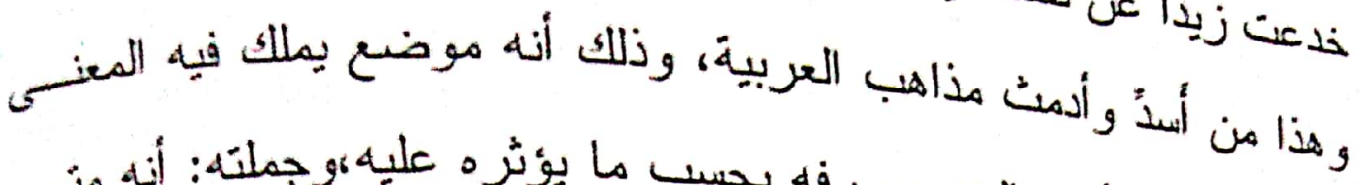

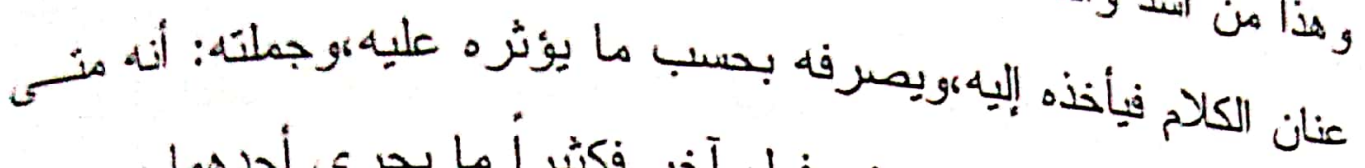

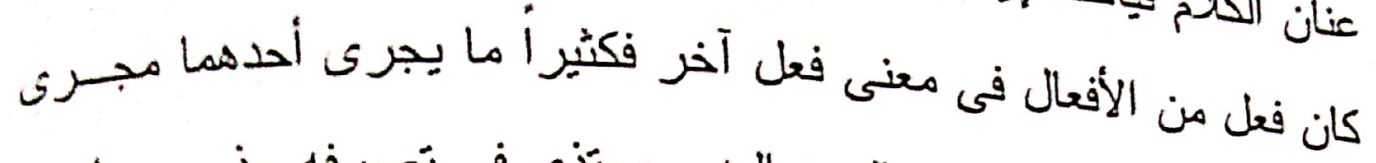

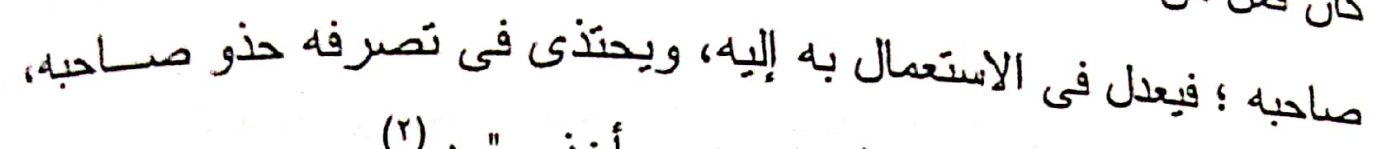

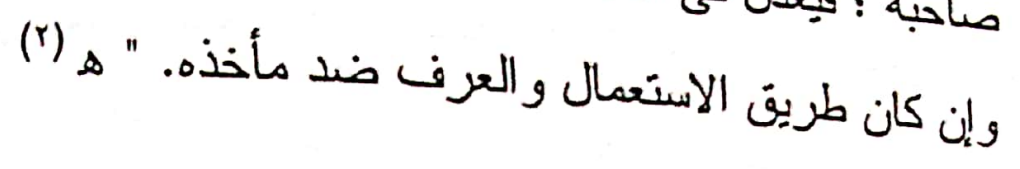

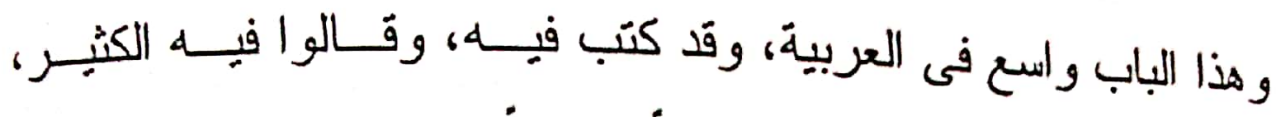
والكثير، و أفرد له الأستاذ عباس حسن مبحثناً مستقلاً فى كتابه الشهير " النحس. الو افى " ؛ فالكلام حوله سيكون إعادة وتكر ار أ.

• مراعاة النظير اللفظى: فقد لجأ ابن جنى إلى هذا اللون فى التأويل رجوعاً

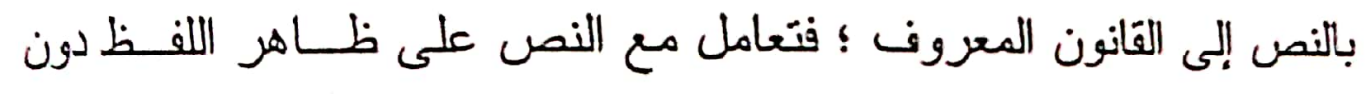
النظر إلى أصالة حروفه ورجوعها عند الجمع، وأيد هذه الآلية بما ورد من إنى

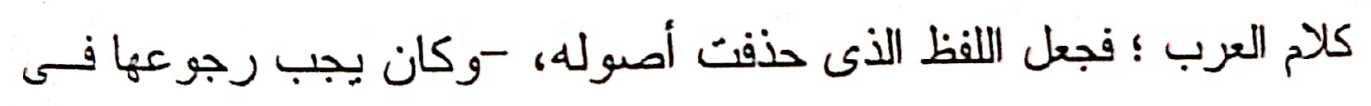

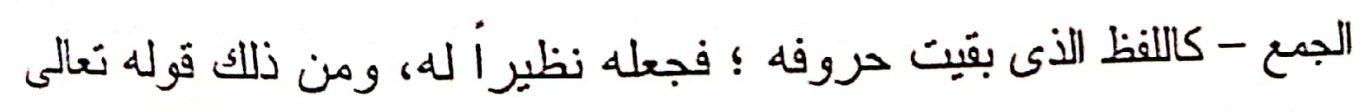

(1) سورة البزَزة: من الآية (9)، وهى قَراءة أبى طالوت عبد السلام بن شداد، والجارود بن

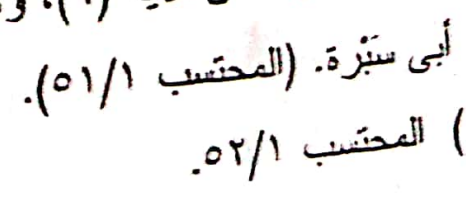




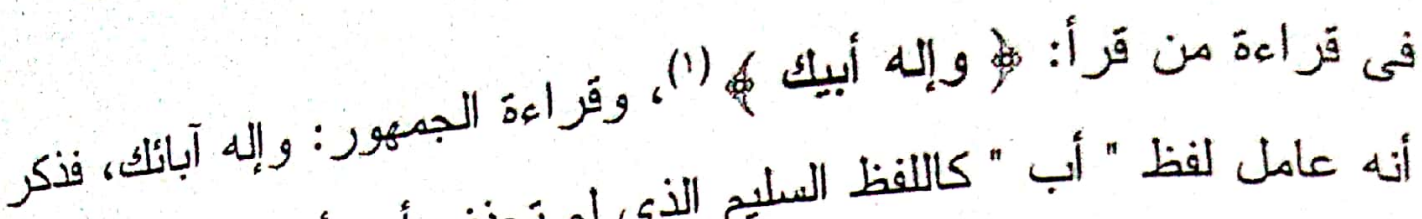

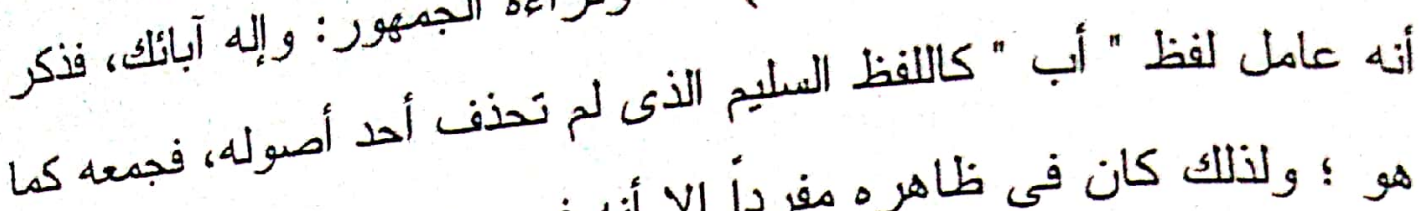

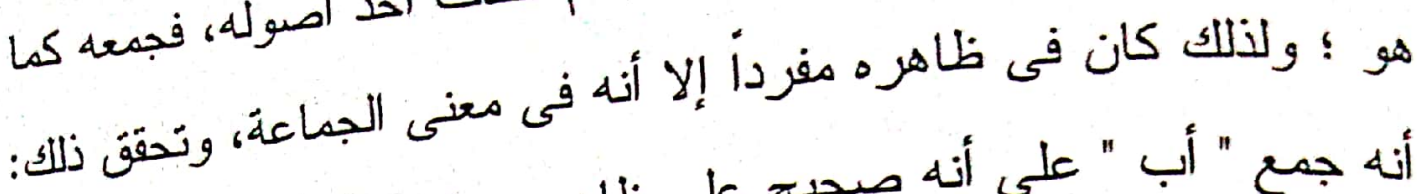

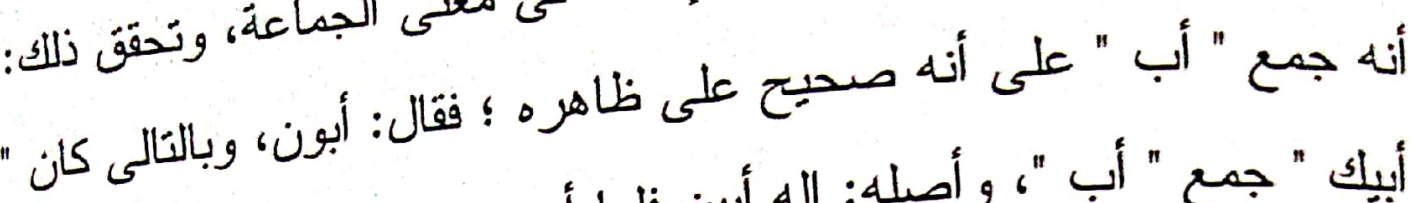

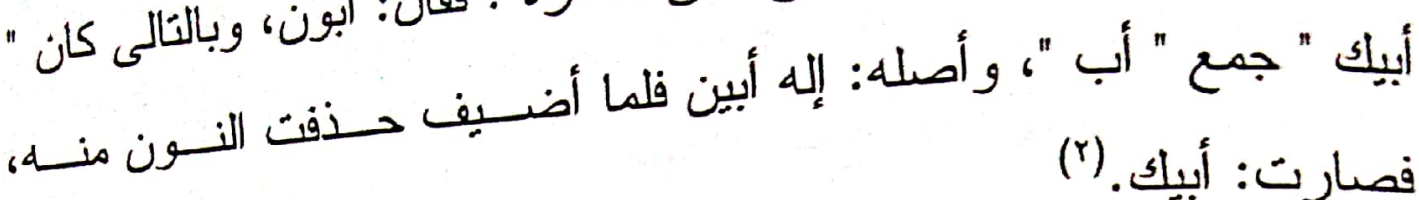
فصارت: أبيك.

وقد وردت مثل هذا لغة لبعض العرب، أى: أنها تعاملت مع النواقص

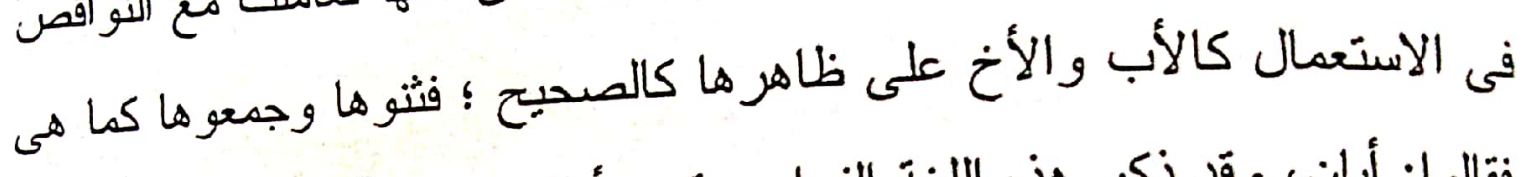

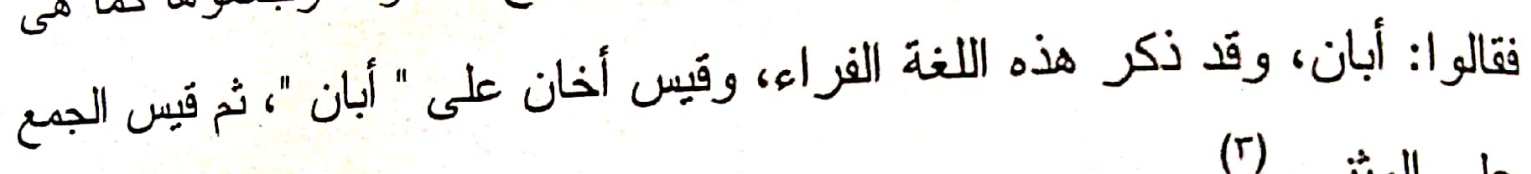

على المثىى. ومما جاء على هذه اللغةَ، وأيد تأويل ابن جنى قول الشاعر:

(§) بكين وفَدَّنْنَا بالأبينــــــا فلما تبينت أصو اتن

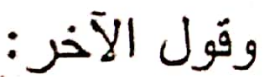

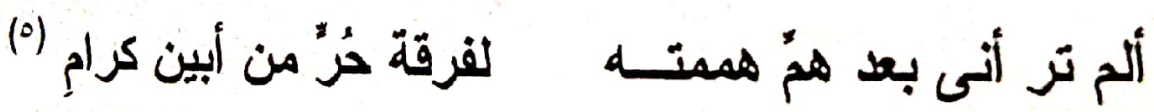

سورة البقرة: من الآية (بسا()، وهى قراءة ابن عباس ويحيى بن يعسـر، وعاصــ

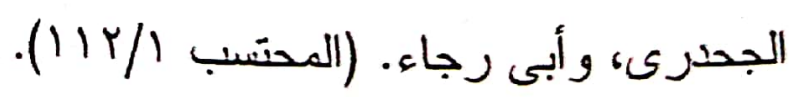

انظر : المحتسب / / الم، وما ذكرته هو فحوى كلام ابن جنى، ومراده.

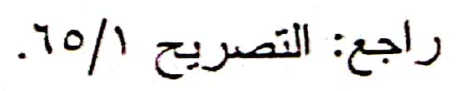

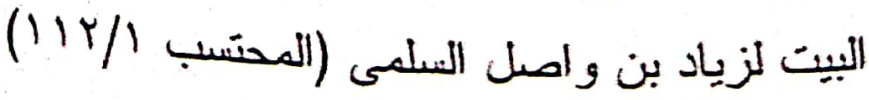

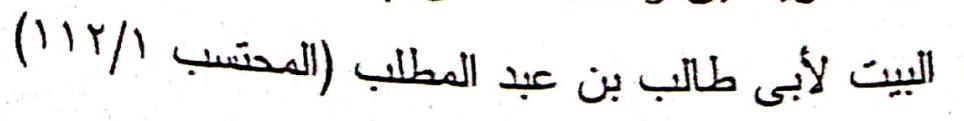

Tr 


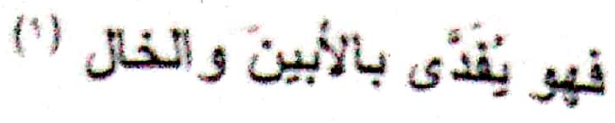

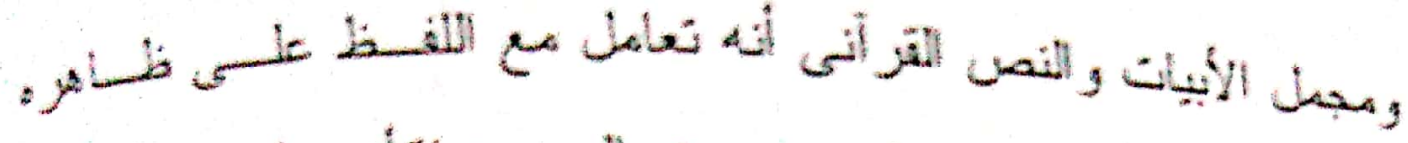

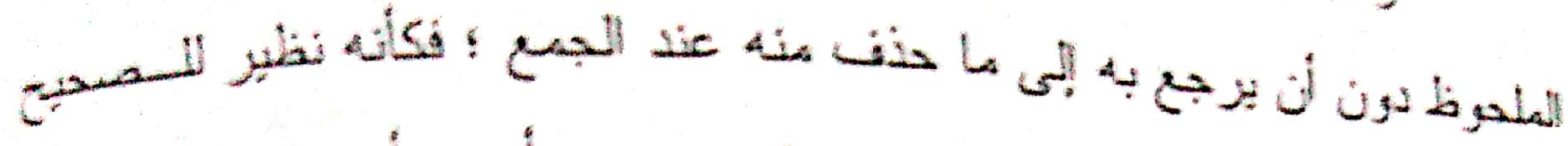

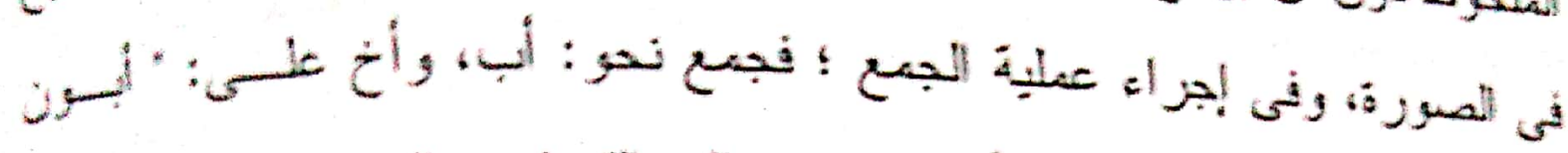

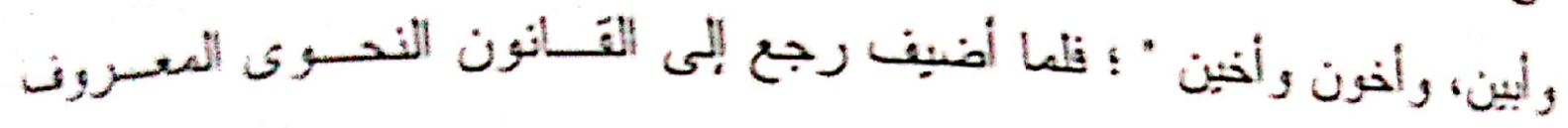

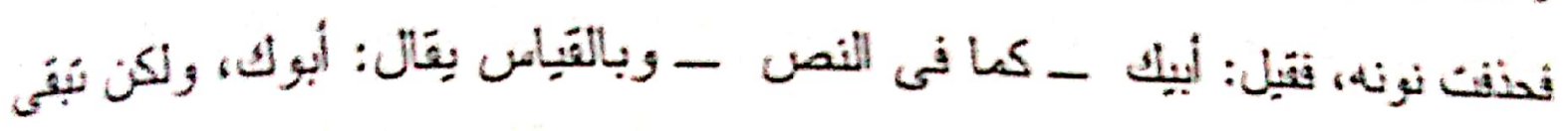

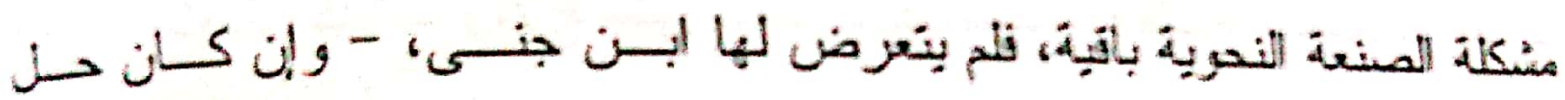
النعارض من حبث المنىى - وهى:

أن الثباء فى أبيلث هل باء الإعز اب أم ياء الضمير ؟، فلو كانست بـاء

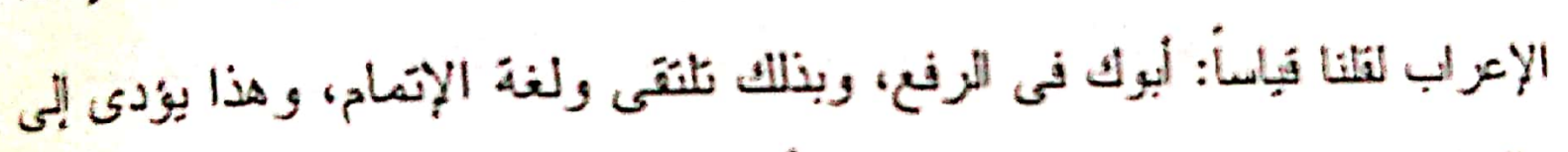

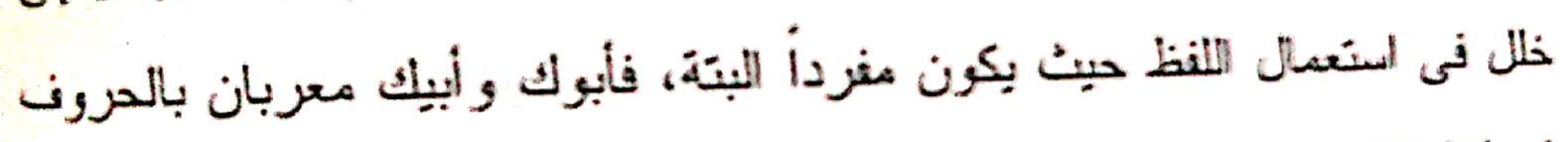

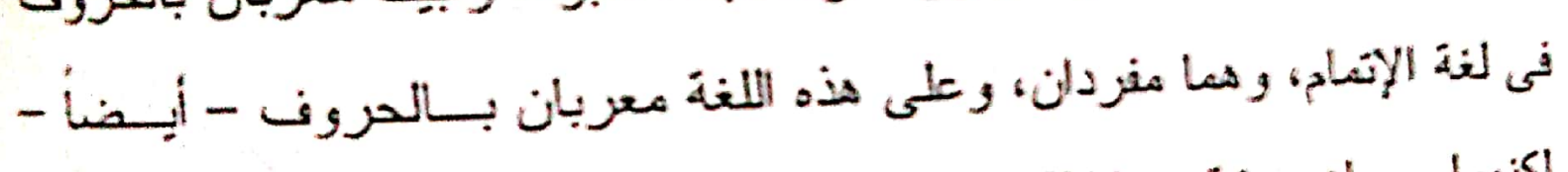

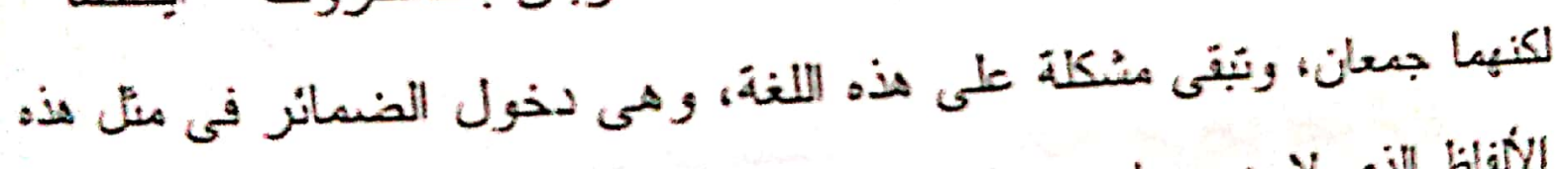

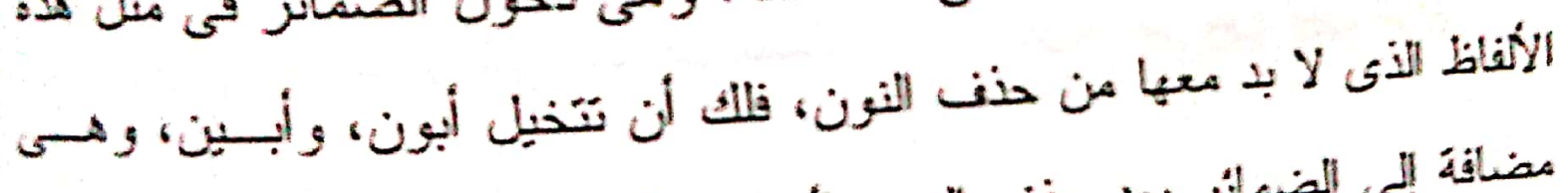

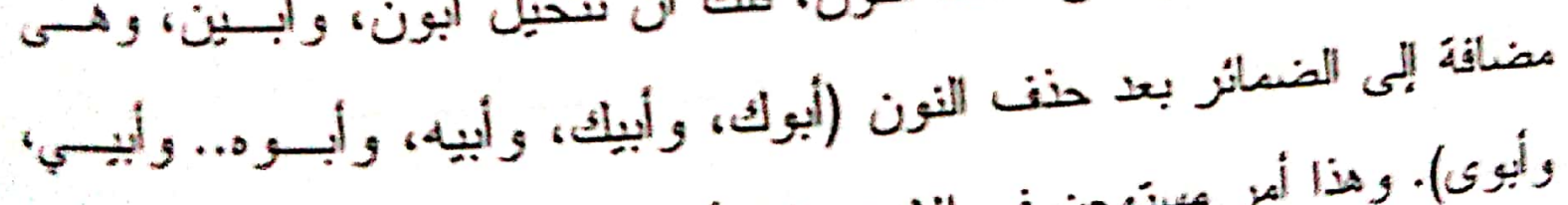

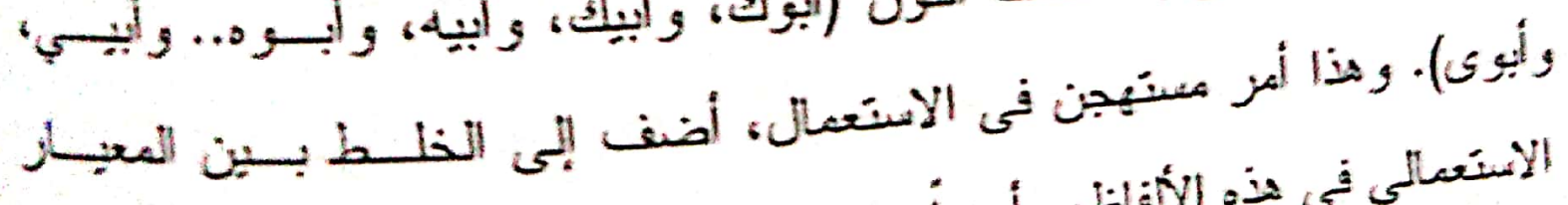

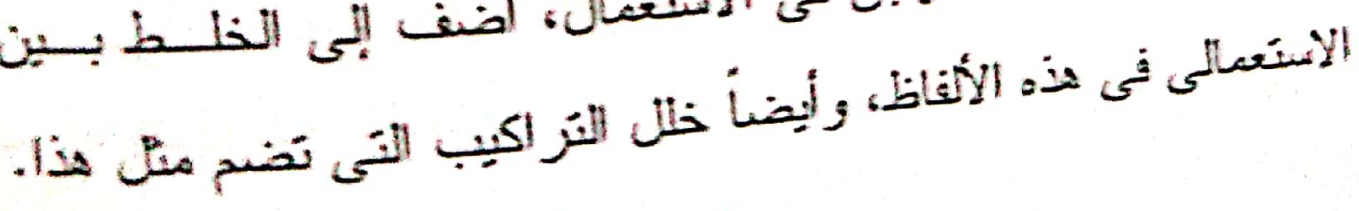

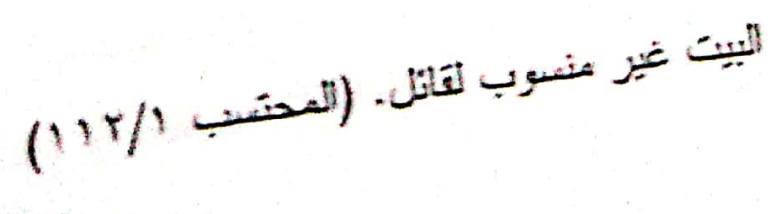


لذلك كان من الصعب سحب التأويل فى أبيك ـ كما تأوله ابن جنى -

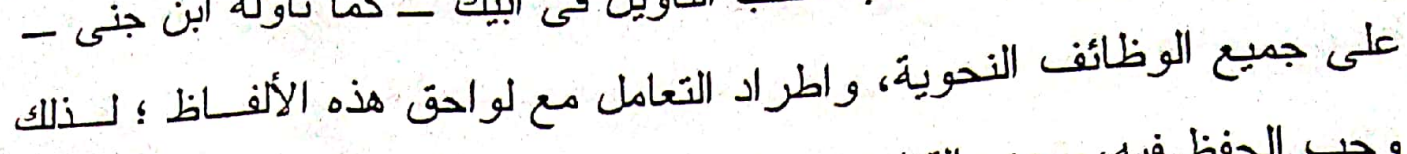

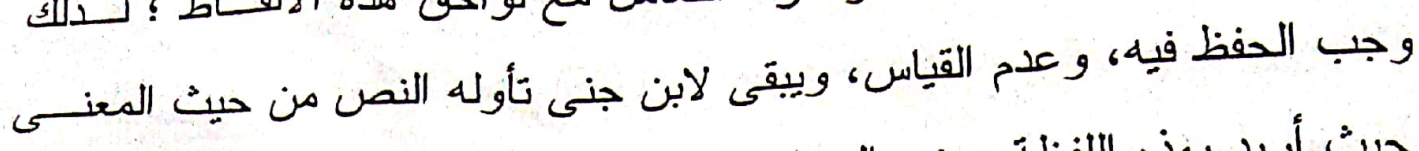

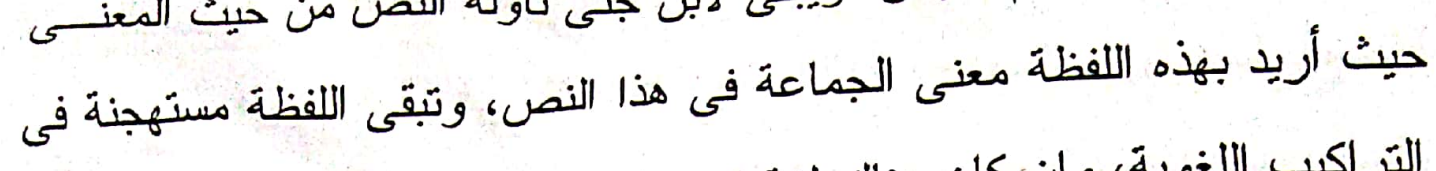
التز اكيب اللغوية، و إن كان هناك لغة فهى قليلة تحفظ، ولا يقاس عليها. أما ورودها فى الشعر فيمكن أن يكون من منطلق هذه اللغة، أو يمكن

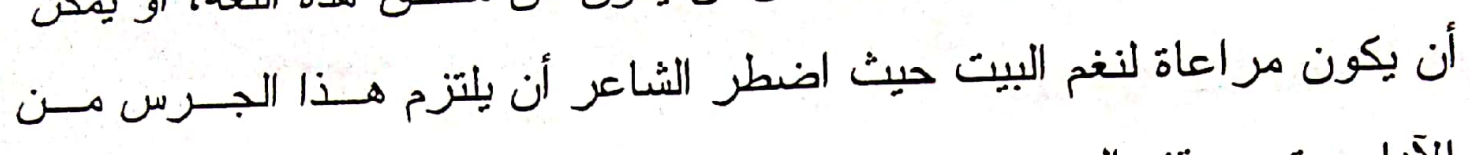
الآداء حتى يحقق البيث جرسه ونغمه، ووقعه من نفس الملتقى. واله أعلم.

التخفيف: كثرت هذه الآلية فى لغة العرب ؛ فاعنمد عليها ابن جنى كثراً،

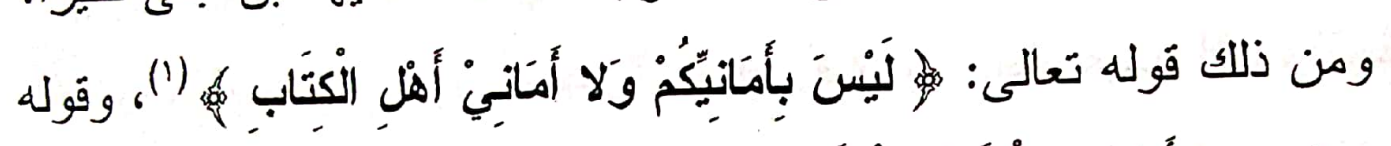

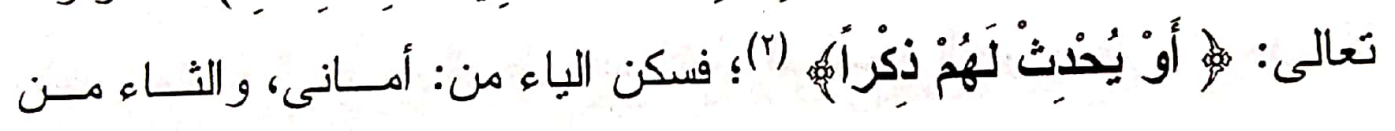

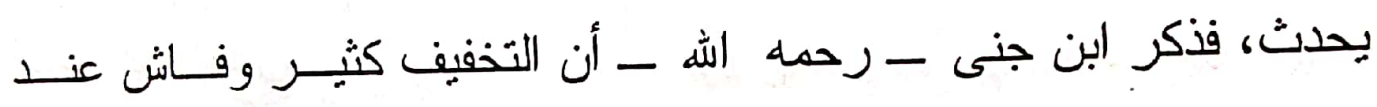
العرب ؛ حتى إنه لم يسمع فى نخو: أثاف النتقيل الذى هو أصل فيها، ولم ترد عنهم به، وجاءت بالتخفيف.

للتخفيف أيضاً ؛ حيث إن الضمة تقيلة.

سورة النساء: من الآية (ب (1))، وهى قراءة: أبى جعفر، وشيبة، والحسن، والحكم بن

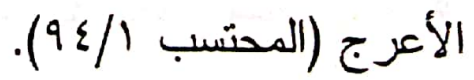

$$
\begin{aligned}
& \text { سورة طه: من الآية (r/1)، وهى قراءة: الحسن. (المحتسب//49). }
\end{aligned}
$$

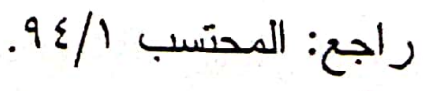

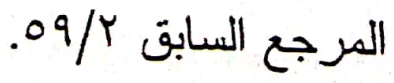

Tro 
ها

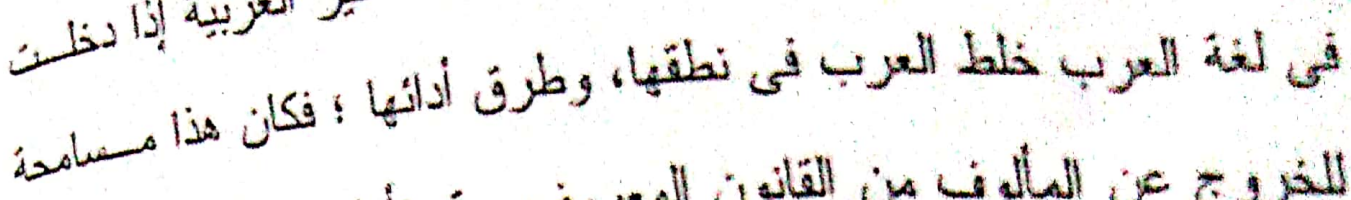

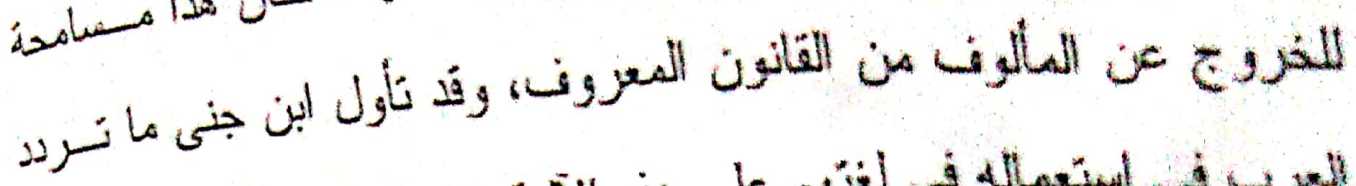

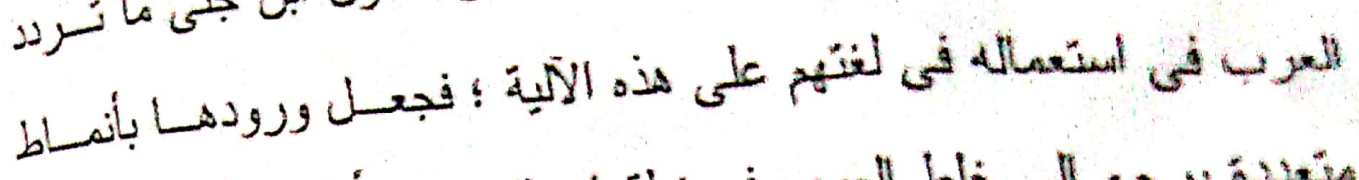

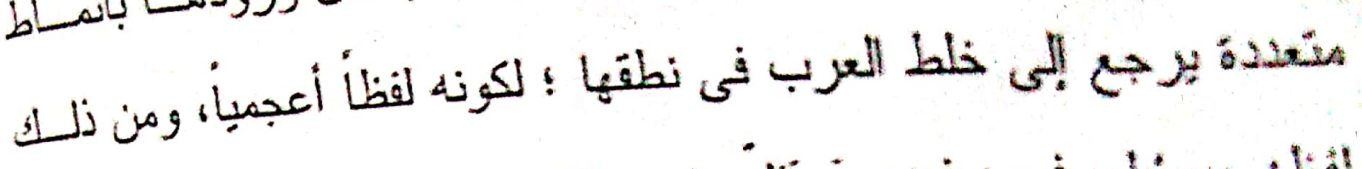

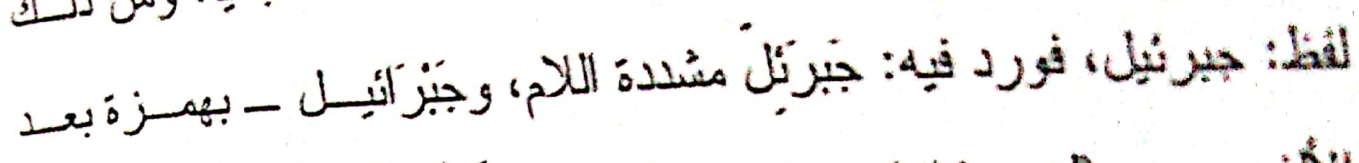

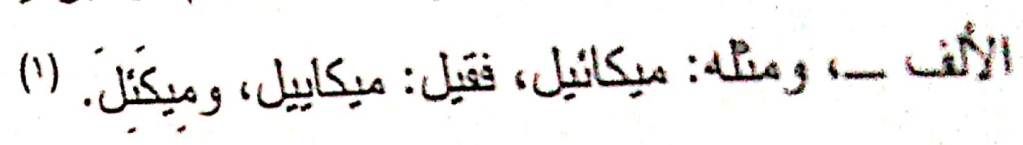
و علق ابن جنى على ذلك بقوله: " أن العرب إذا نطقـت بـالأعجمى خلطط فيه ... " ه (")، وقال : "... أنهم قد بحرفون ما هو من كلامهم، فكيف ما

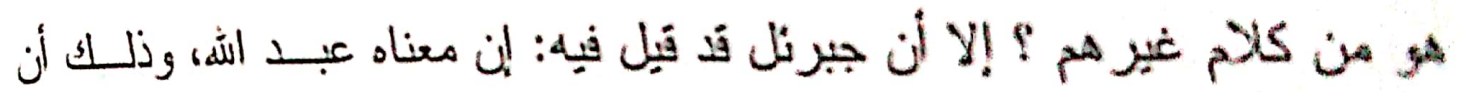
الجبر بمئزل، الرجل، و اللرجل عبد الله، ولم يشمع الجبر بمنى الرجل إلا فـى شنعر ابن أحمر.

$$
\begin{aligned}
& \text { المزجم المبائ }
\end{aligned}
$$

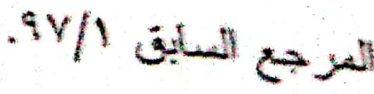

$$
\begin{aligned}
& \text { المحتسب }
\end{aligned}
$$


الموازنة بين التزر اكيب: فكثيراً ما يوازن ابن جنى بين نــركيبين، يكــون

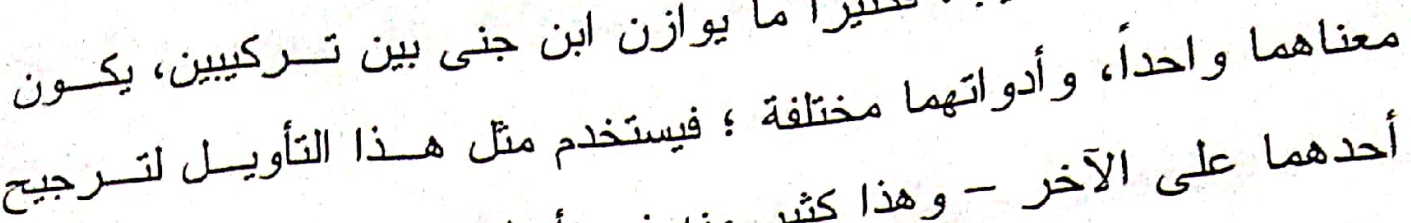

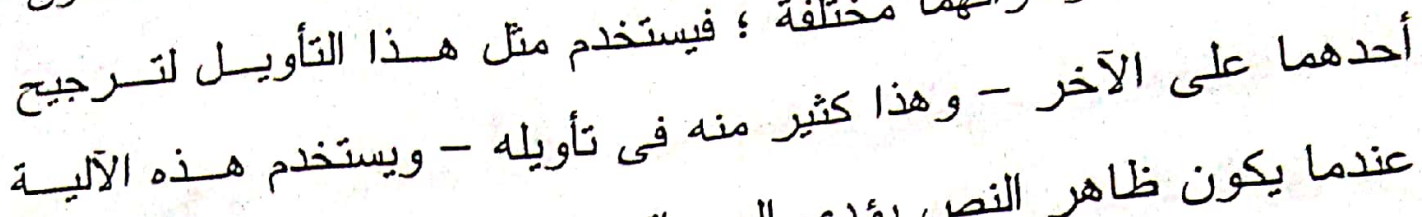

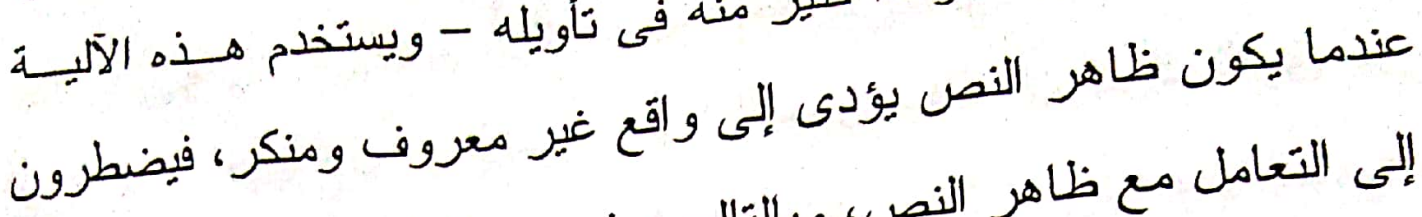
إلى التعامل مع ظاهر النص، وبالتالى يرفضونه كلية.

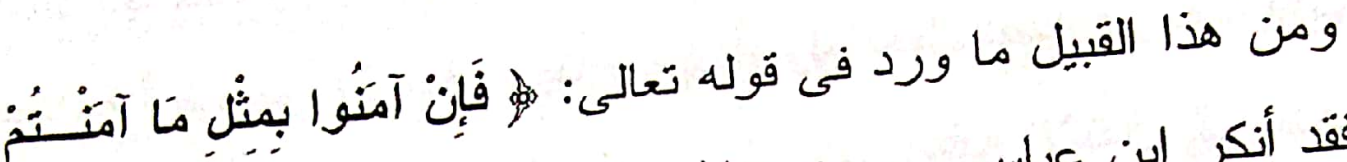

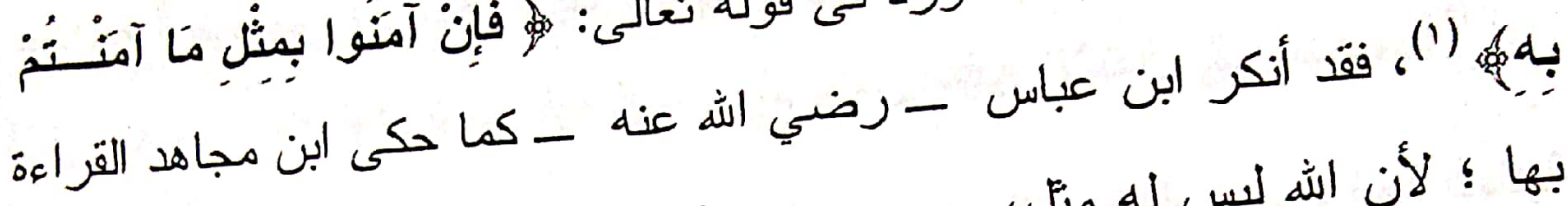

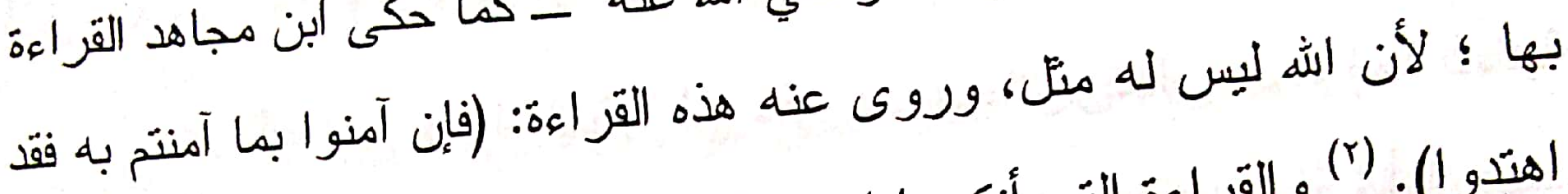

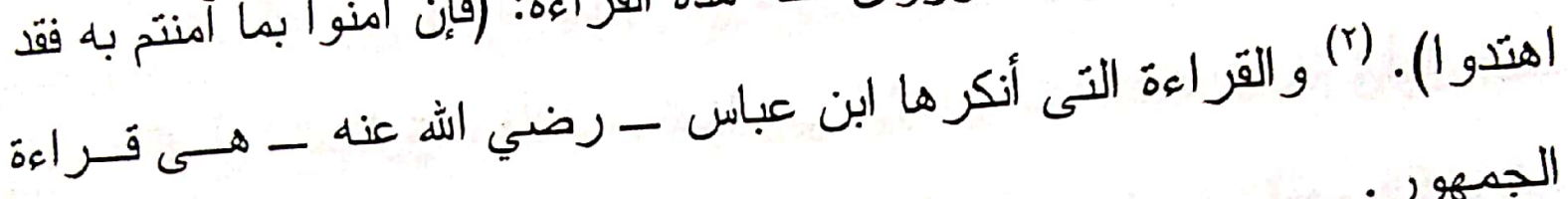

أما ابن جنى فقد استحسن كلام ابن عباس ؛ ومرجــع الاستحسسان لا لا

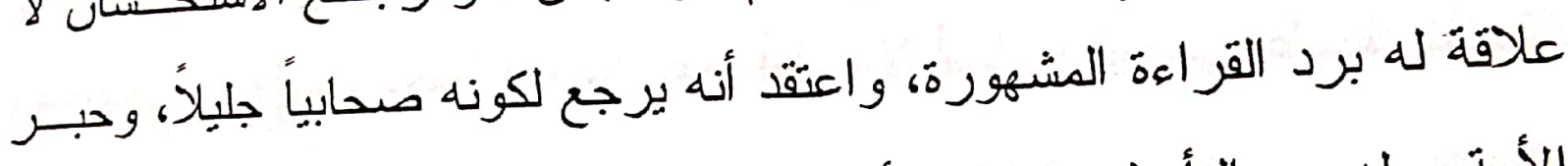

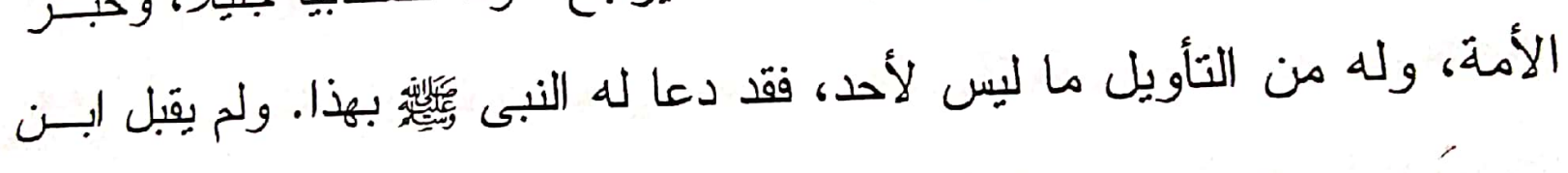
جنى هذا الاعثر اض فى القراعة المنو اترة المجمع عليها -

فو ازن ابن جنى بين النصين، الأول: فإن آمنوا بمثل.... - الذى ذكر ابن عباس بأنه لا يقر أ به لنفى المثلية عن الله -، و الثانى: فإن آمنوا بما آمنـنم بـه.... - الذى أقر القراعة به ابن عباس - فجعل الثـانى معنـى الأول، إلا أن العرب قذ تأتى بكلمة مثل فى نحو هذا توكيداً وتسديدا، يقول الرجل إذا نفى عن

$$
\begin{aligned}
& \text { سورة البقرة: من الآية (IrVV). } \\
& \text { راجع: المحتسب /11/1 }
\end{aligned}
$$




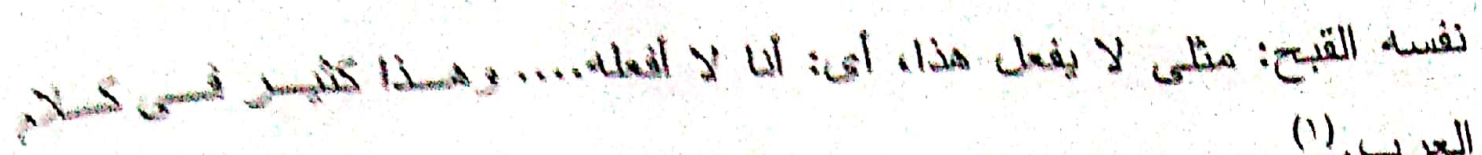

$$
\text { (1) العربد) }
$$

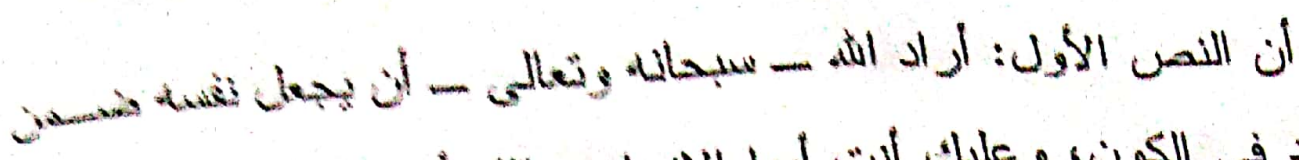

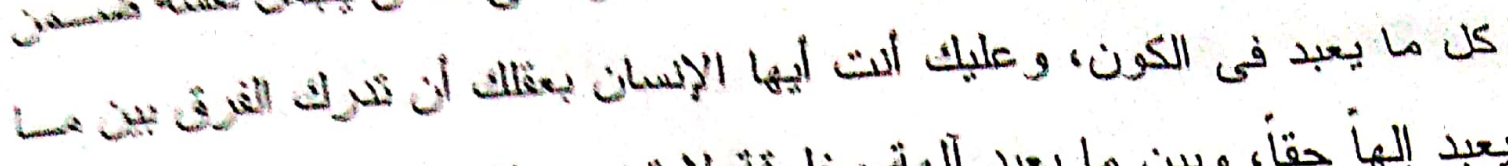

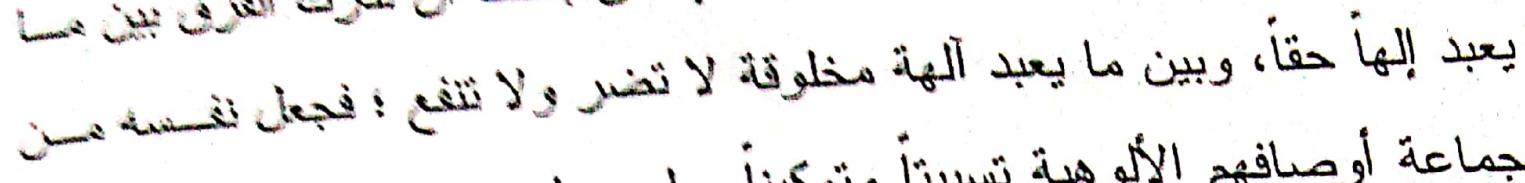

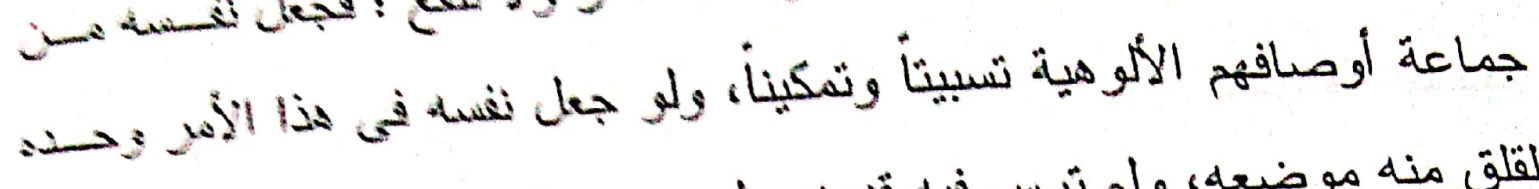

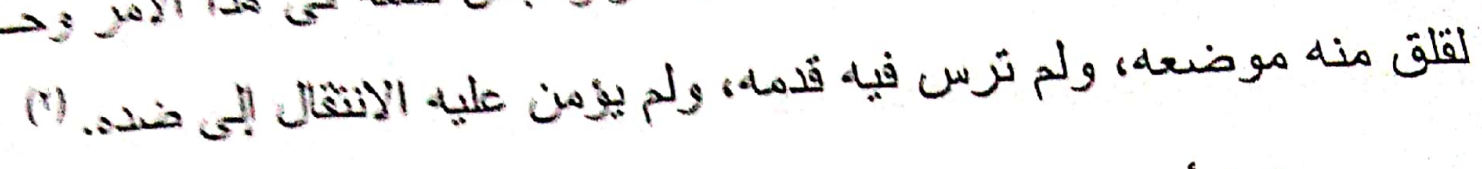

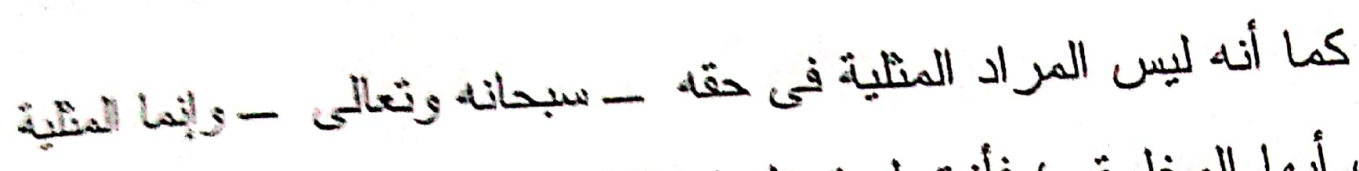

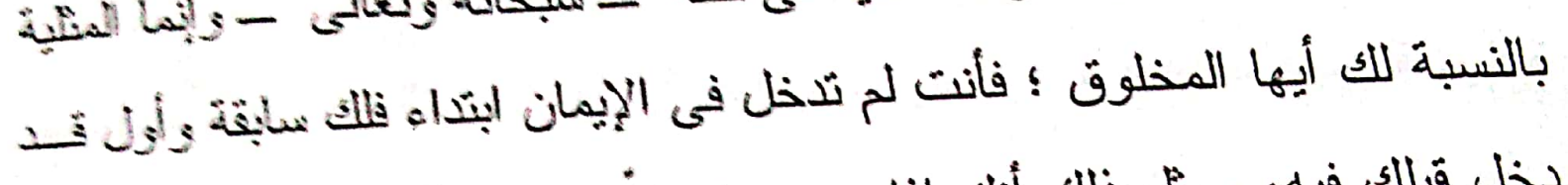

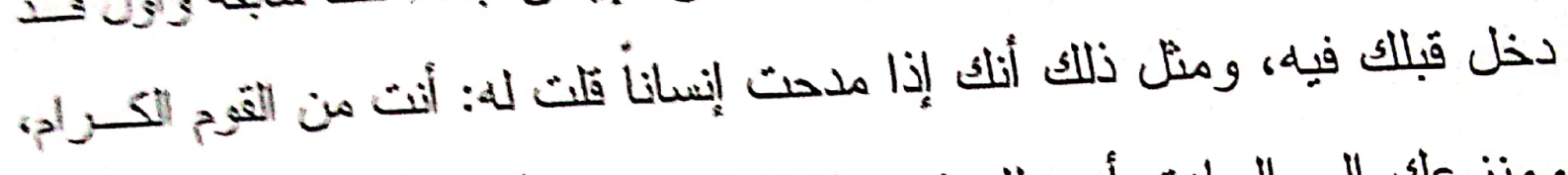

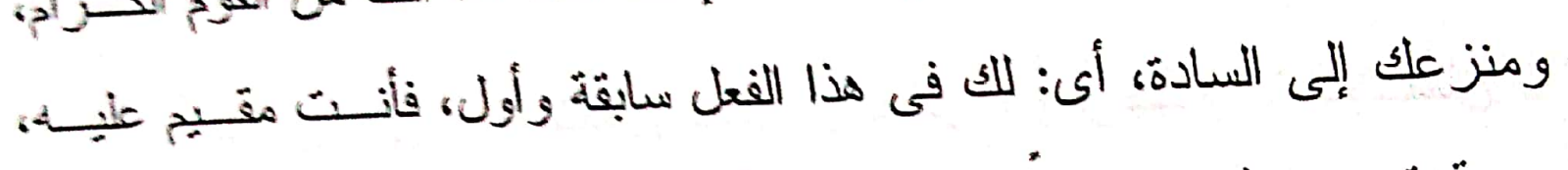

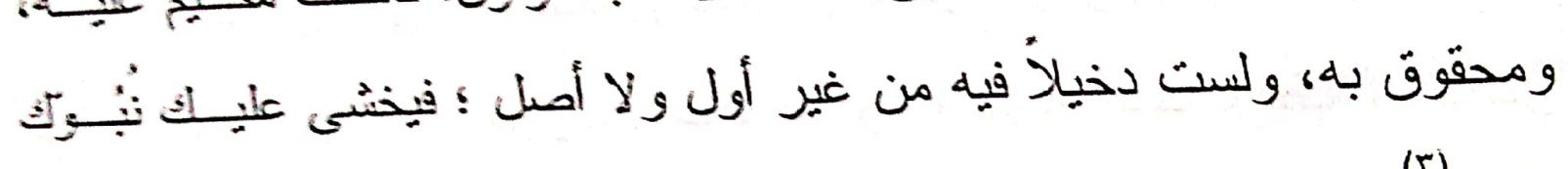

(r) (ن)

قال.ابن جنى: "ولما أريد مثل هذا الثناء على اللة - تنالى - ولم يجز

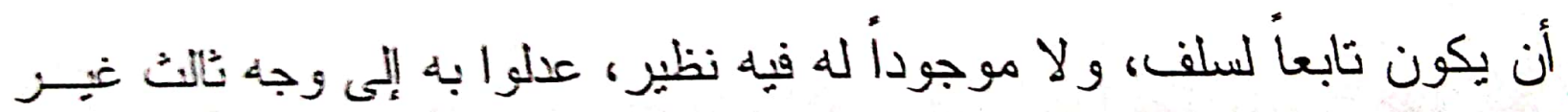

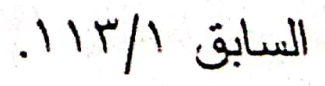

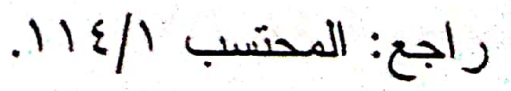

$$
\begin{aligned}
& \text { المرجع السابق /11ا. 11. }
\end{aligned}
$$


الاثثين المذكورين، وهو أن جعل قديماً فيه، راستاً عليه ؛ فكان أثبت له من أن

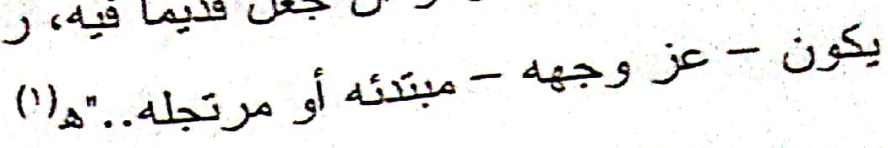

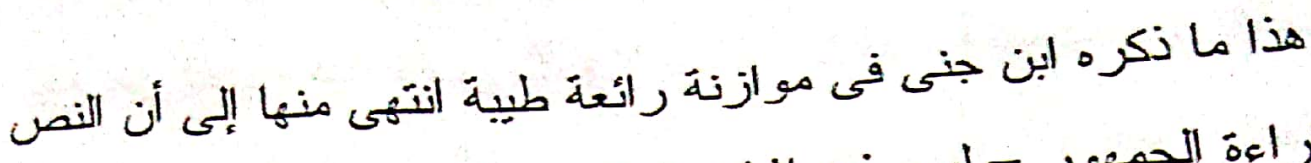

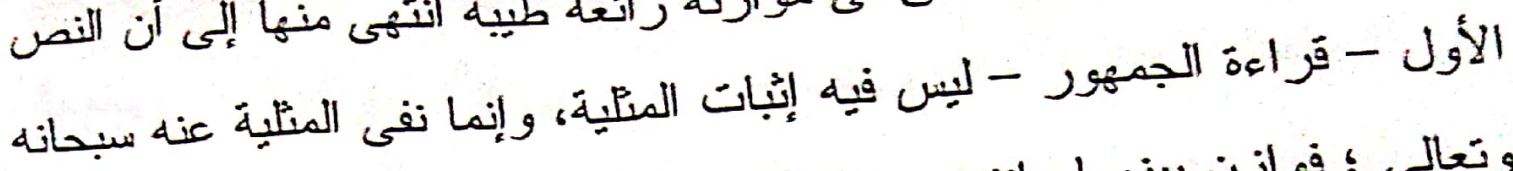

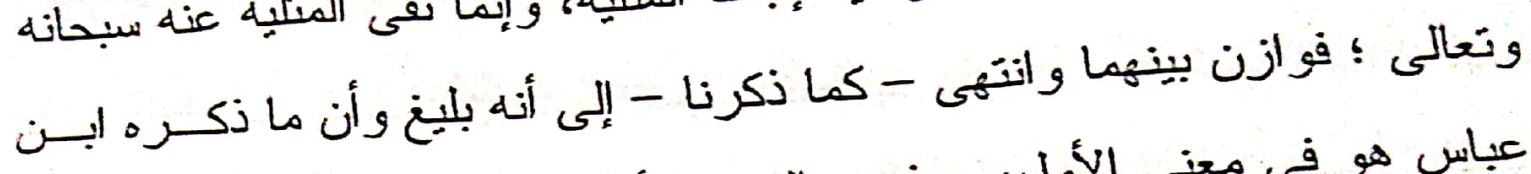

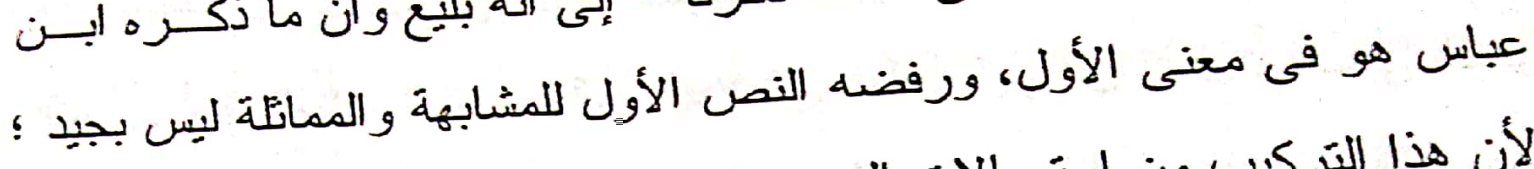
لأن هذا التزكيب من استعمالات العرب مني البليغة.

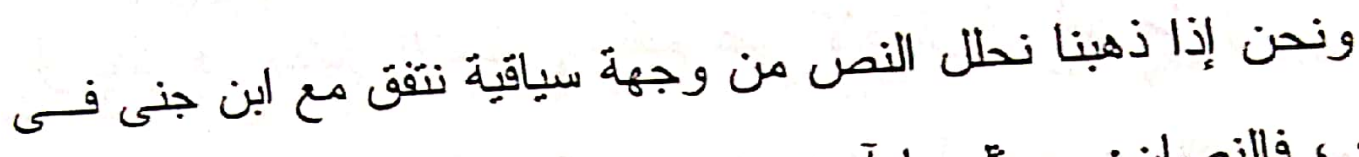

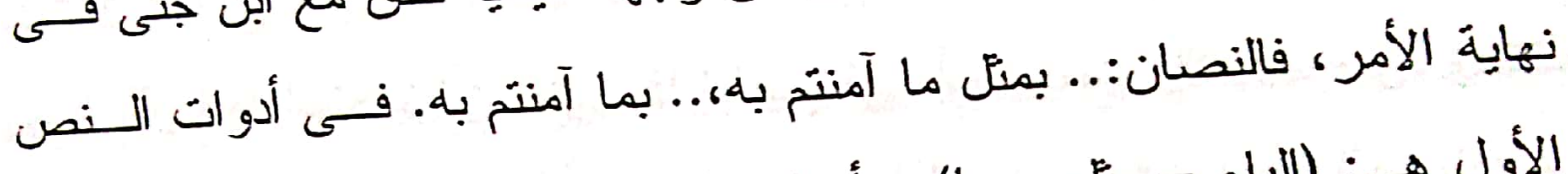

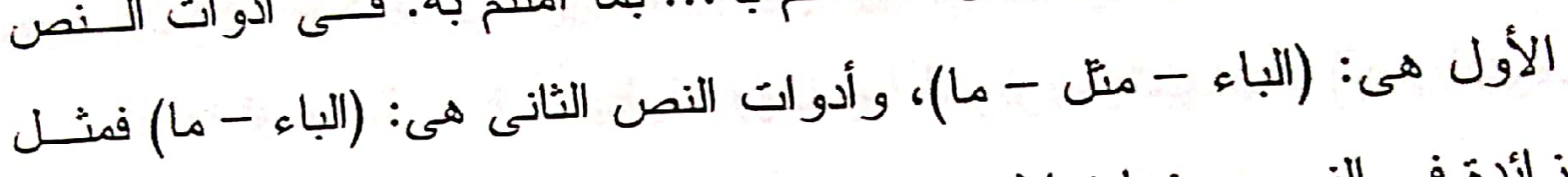

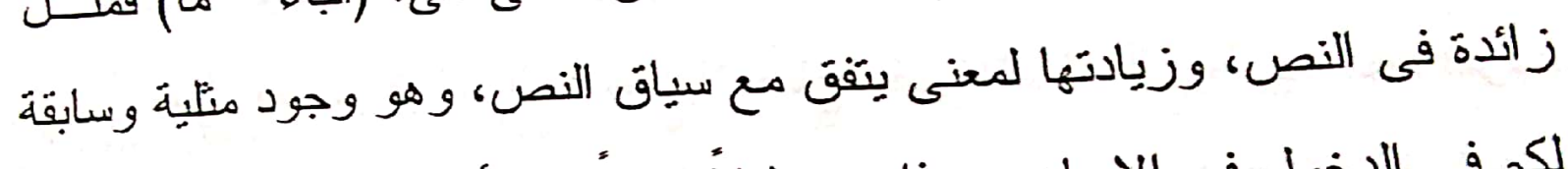

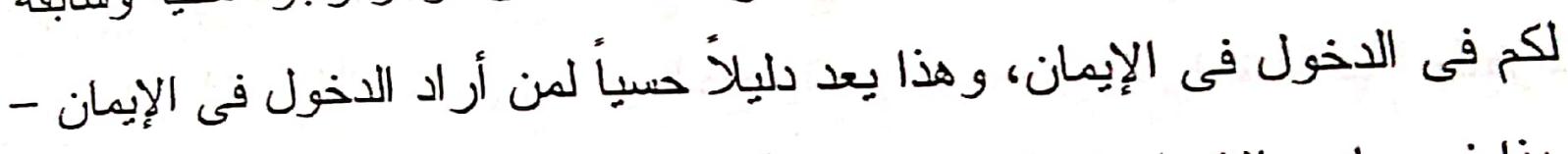

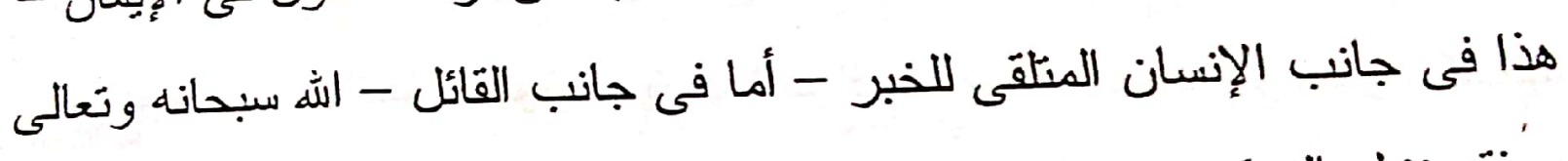
- فقد نزل التزكيب منزلة الدليل لهم والحجة عليهم ؛ فصور المثلية المحسوسة

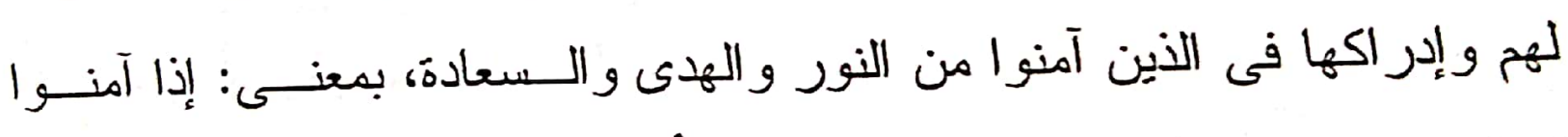
فسيكون حالهم منل حالكم.

من المحتمل أن يكون ثمة خوف فى نفوسهم من تزك آلهاتهم ؛ فضرب لهم المنلية التى يمكن أن تذرك فيمن آمن. 
و أيضاً قول العرب: متلك لا يفعل هذا، أو مثلى لا يفعل هـذا، يعنسى

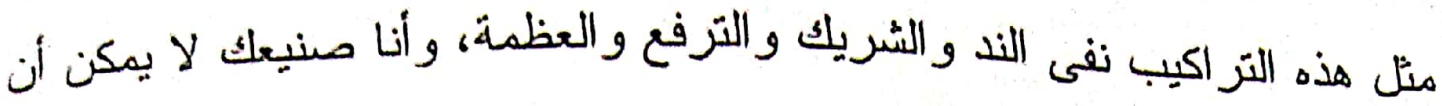
يقع من أحد، وهذا خاص بك ولا يصدر إلا منلك ؛ فيجب حمل النص على هذه المعانى.

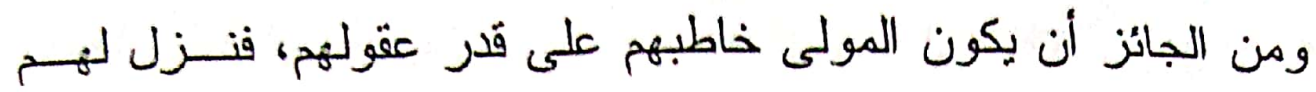
النص وأر اد المثلية المحسوسة، وتجرد فى خطابه لهم عن كـلـ معسانى القـــوة و الكبرياء حتى يترك لعقولهم اختيار العبودية له، دون إظهار القدرات التى يمكن

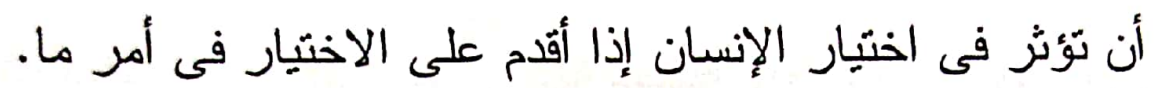

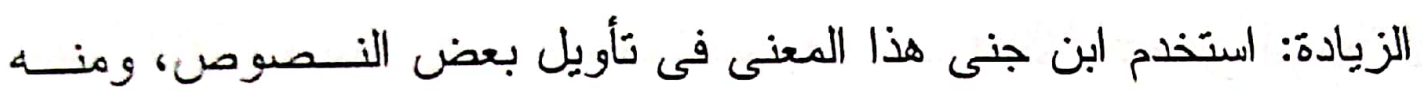

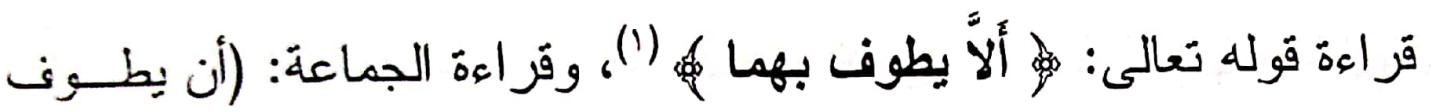
بهما)، فمعنى قر اعة الجماعة: لا جناح على الإنسان أن يطوف بهما تقربــأ

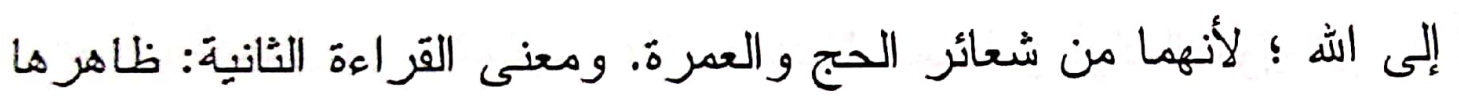
يوحى أن الإنسان يجوز له تزك الطواف، كما أجيزت له الرخص، كالقصر وخلافه ؛ لذلك كانت لا زائدة فى القراءة الثانية، ويكون المعنى: فلا جناح

عليه أن يطوف بهما.. (r)

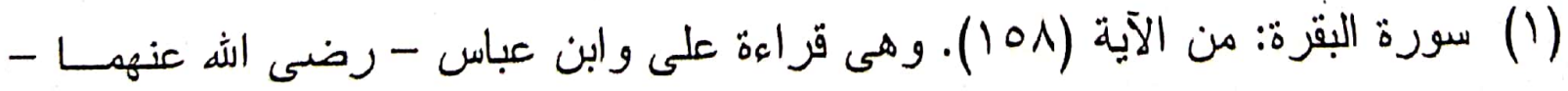

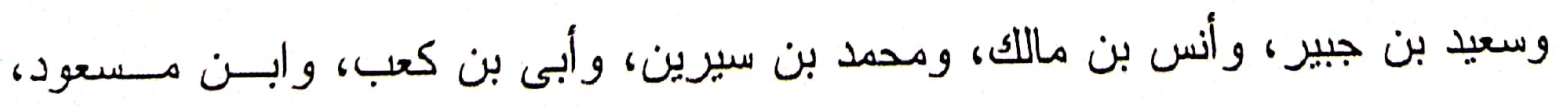

$$
\begin{aligned}
& \text { وميمون بن مهران. (المحتسب (10/1). } \\
& \text { راجع: المحتسب /117/. }
\end{aligned}
$$


• ملائمة المبنى لاسم المعنى: قد وردت أسماء معانى مخالفة لما ورد عسن

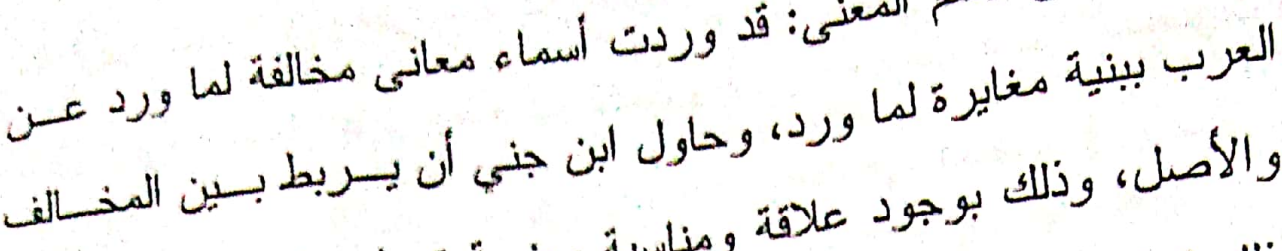

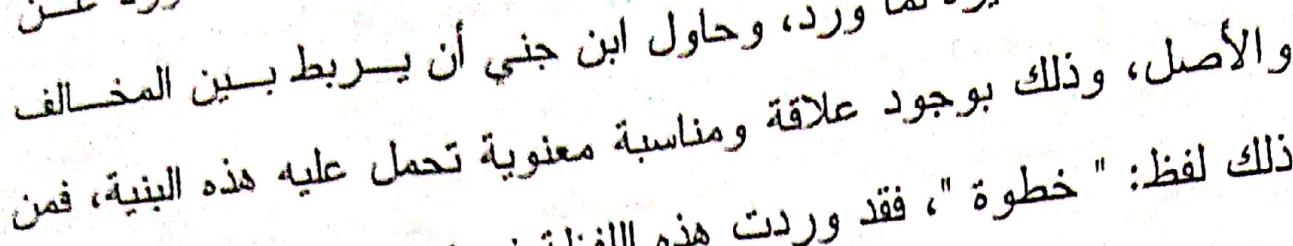

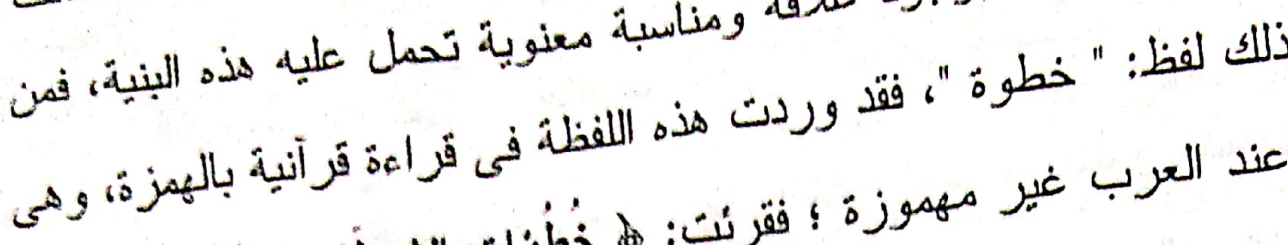

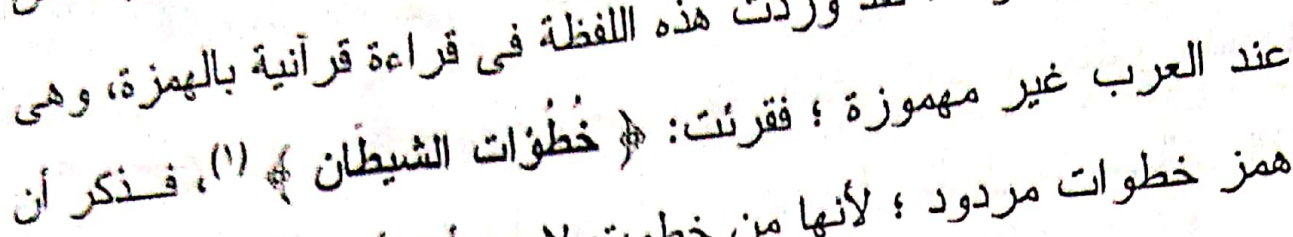

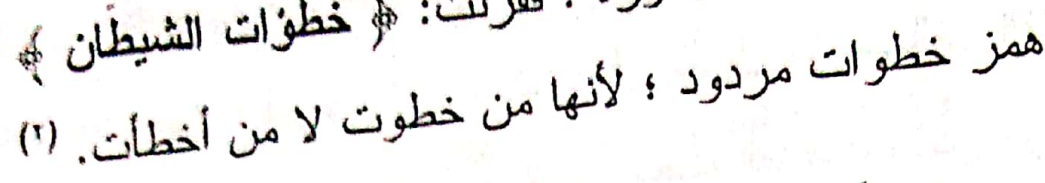
وقد تأول ابن جنى ما ورد على تأويل ضعيف لا رابط بربطه بساللفظا

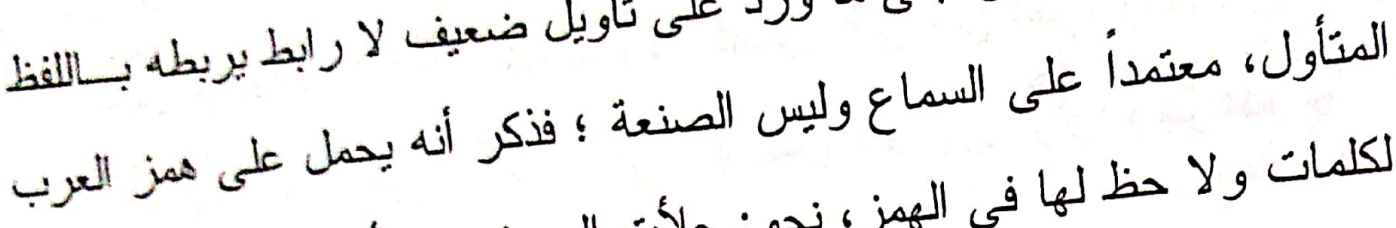

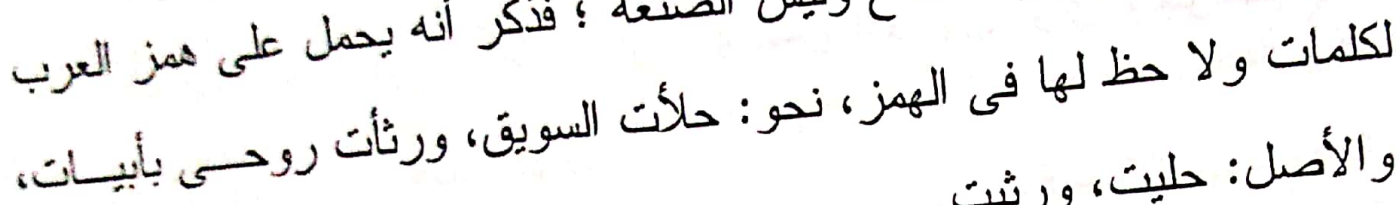
و الأصل: حليت، ورثيت...

ولكنه عاد وحاول أن يربط بين اللفظ وسياق المعنى ؛ فحمل اللفظ فى

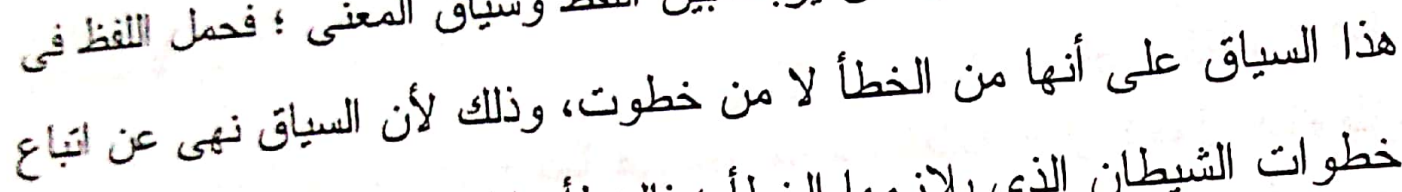

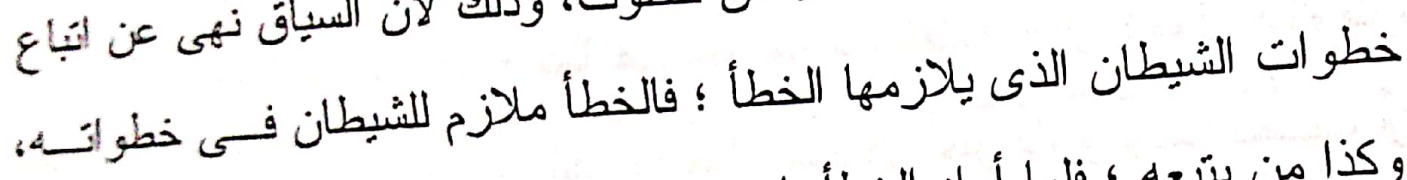

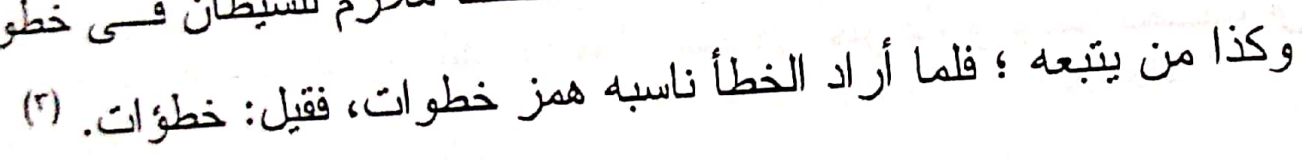
وكأنى بابن جنى بريد أن بسجل لنا أن صوت الهمزة جعل لازم الخطا

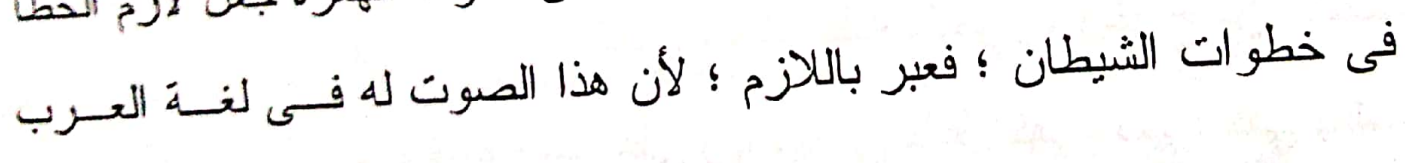
(1) سورة البقرة: من الآية (141)، وذكر ابن جنى أنها قراءة الإمسام علـى، والأعـرج ج

$$
\begin{aligned}
& \text { (المحتسب (IIV//). } \\
& \text { راجع: المحتسب 11V/1. } \\
& \text { المرجع السابق ل11 V/ }
\end{aligned}
$$




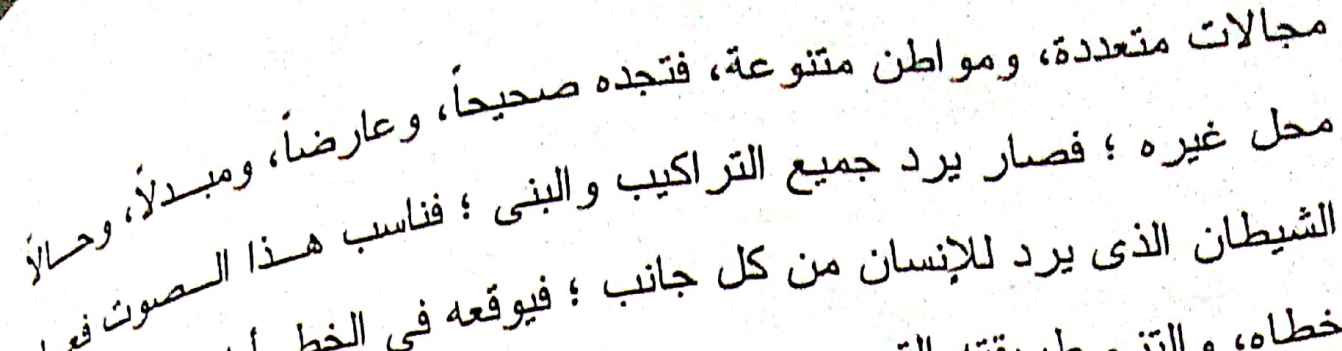

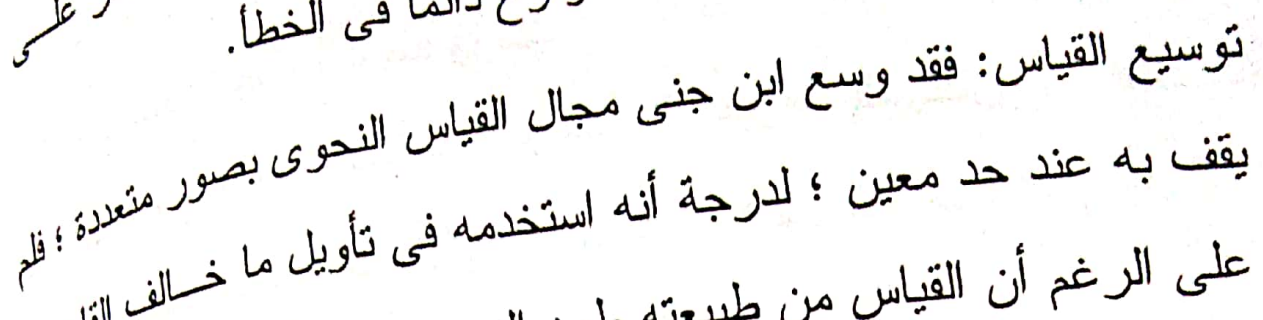

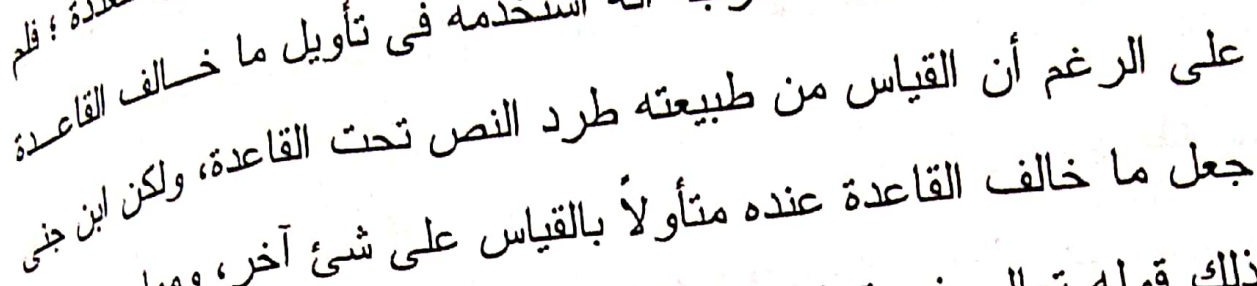

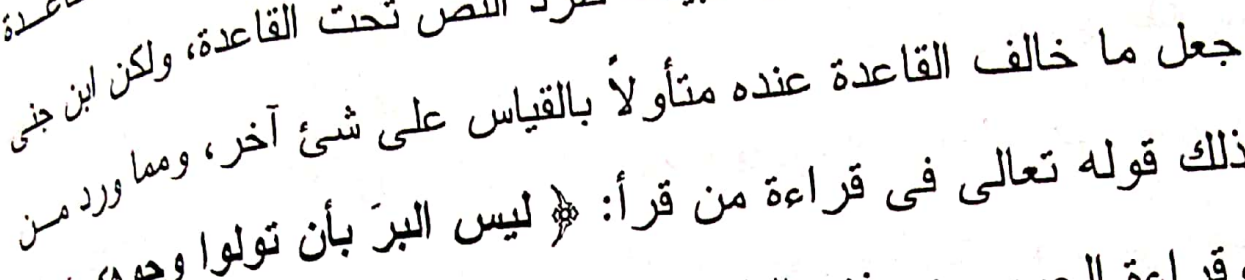

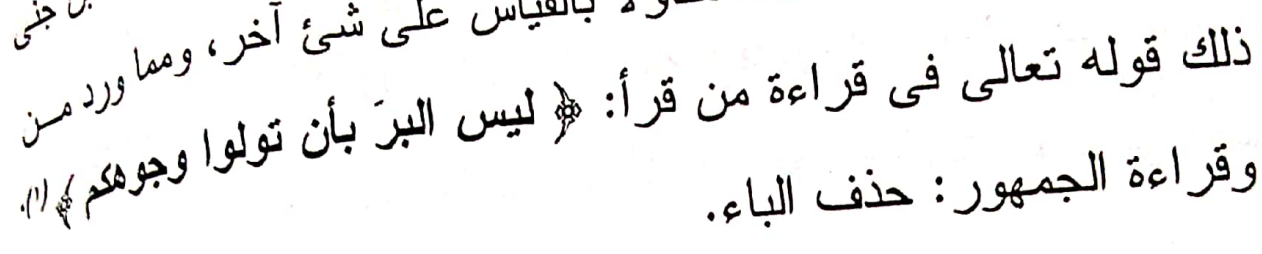
وقد علق ابن مجاهد على هذه القراعة بأنه إذا كانت هكذا فلا يجوز أ. وقر اعة الجمهور : حذف الباء.

وحجة ابن مجاهد - كما هى مفهومة من كلامه - أن دخول الباء بلزم

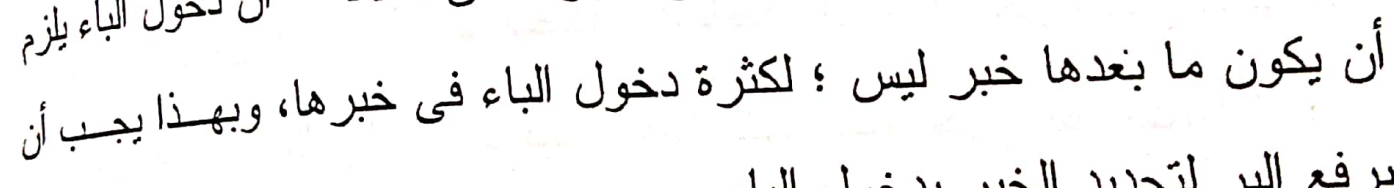
يرفع البر لتحديد الخبر بدخول الباء.

لكن ابن جنى تأول هذا النص وحكم عليه بالجواز ، وخرج من مأخــ ابن مجاهد بتأويل زيادة الباء قياساً على زيادتها فى فاعل كفى، ندو : كفى بالنة..

$$
\begin{aligned}
& \text { (1) سورة البقرة: من الآية (IVV))، وهى قر اعة أبي، وابن مسعود (المحنب/IVV)). }
\end{aligned}
$$

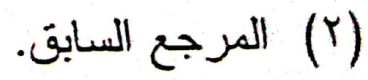


وبهذا القياس يكون دخول الباء فى الاسم جائز ؛ لأن بأن نولوا... هى الاستــ

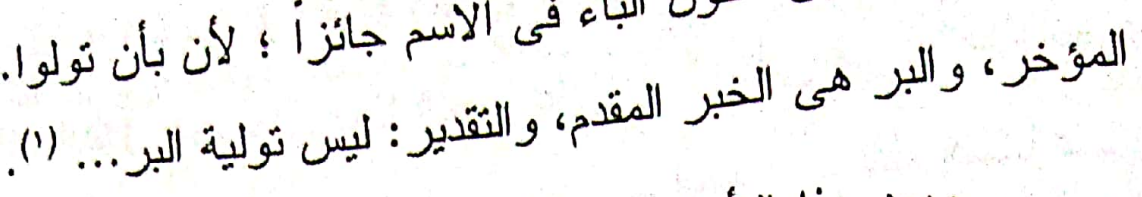

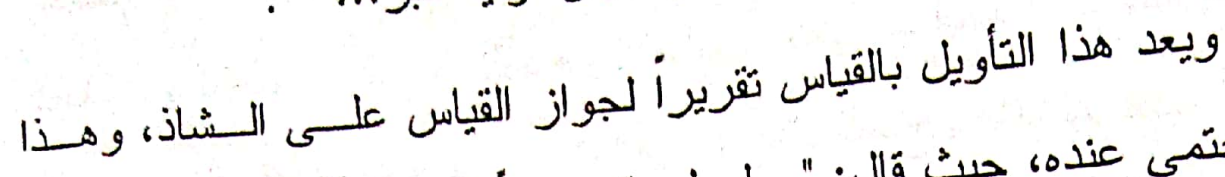

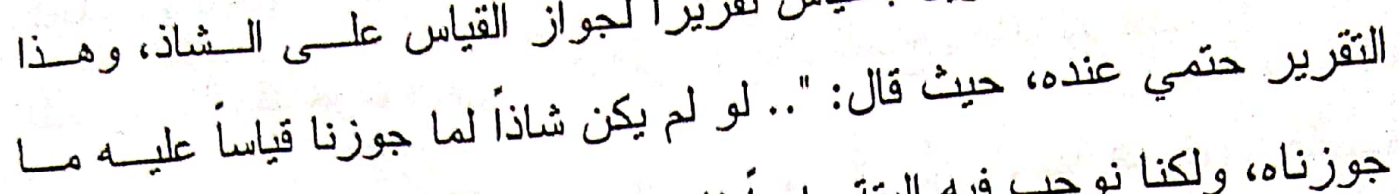

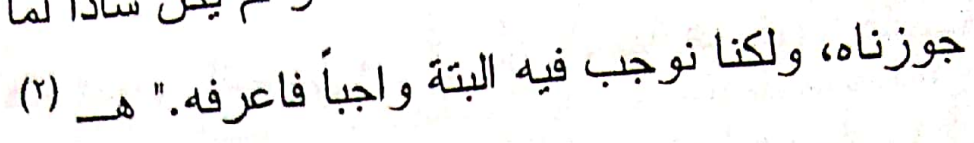

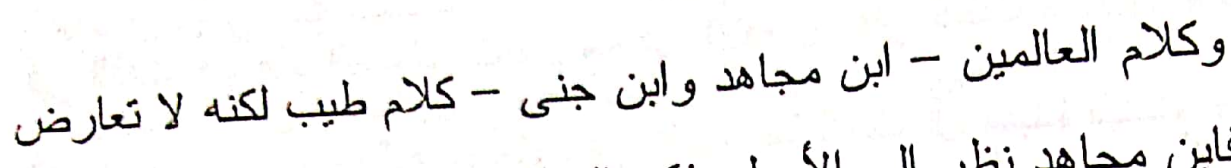

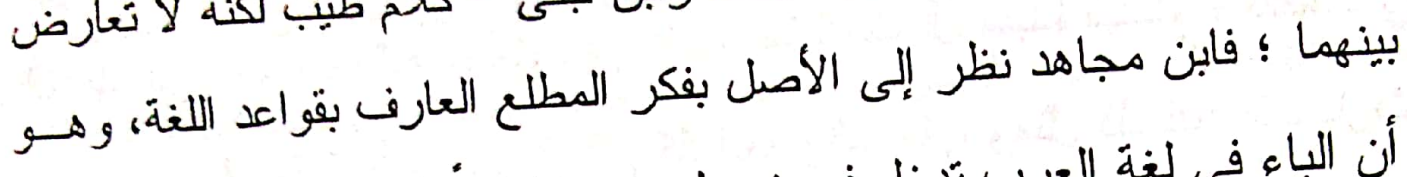

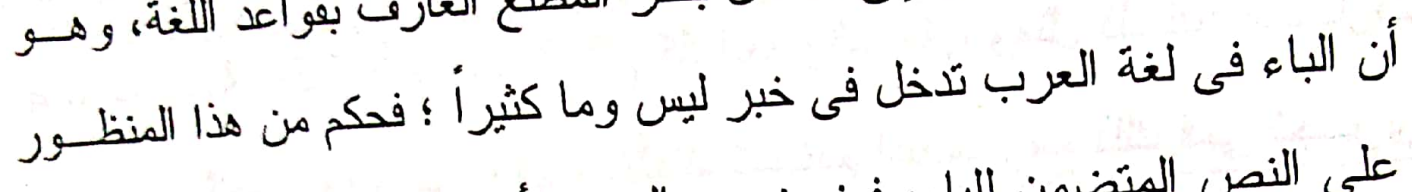

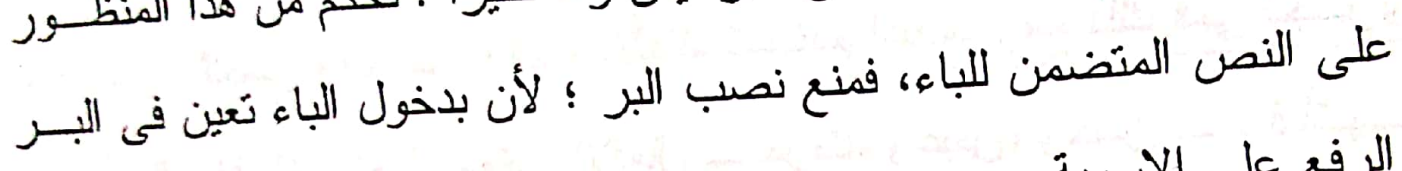
الرفع على الاسمية.

وابن جنى نظر بفكر اللغوى المتمرس فحكم ونظزّر لها بزيادة الباء فى في الفاعل، فقاس عليه زيادتها فى الاسم.

توسيع الدالة المعنوية للوظيفة النحوية: من المعلوم أن الوظائف النحويسـة متعددة فى الأسماء، أما فى الأفعال و الحروف فلا تخرج وظيفة الفعل عن

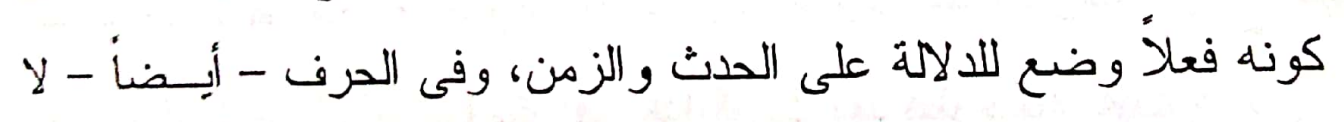
تخرج عن كونه حرف معنى وضع لمعنى معين مع التأثير فى مدخولـه، فمن ذلك أل المعرفة وضعت للنعريف و التأثبر فى مدخولها، ولكن الأمسر امتذ بالنحاة إلى أن جعلو الها معنى التحظيم و المدح إذا دخلت فى الأعلام.

$$
\begin{aligned}
& \text { راجع: المحتسب /V/V/ II 111 (بتصرف). }
\end{aligned}
$$

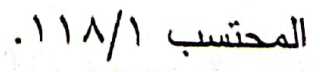

Trt 

然

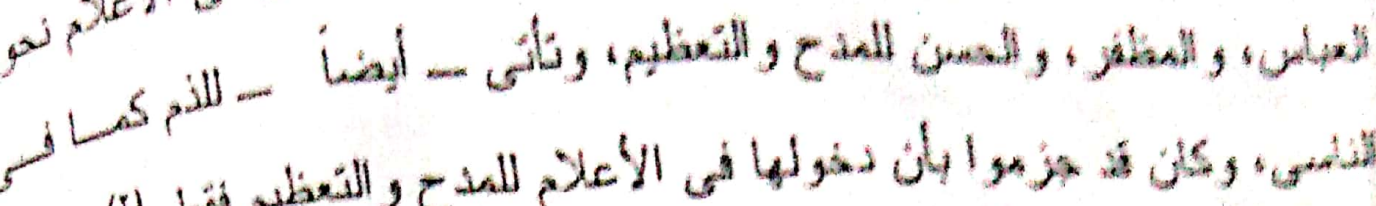

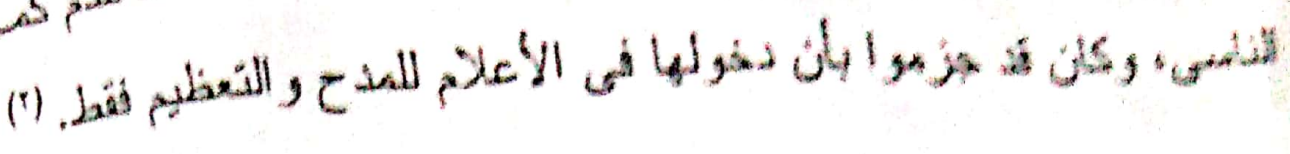

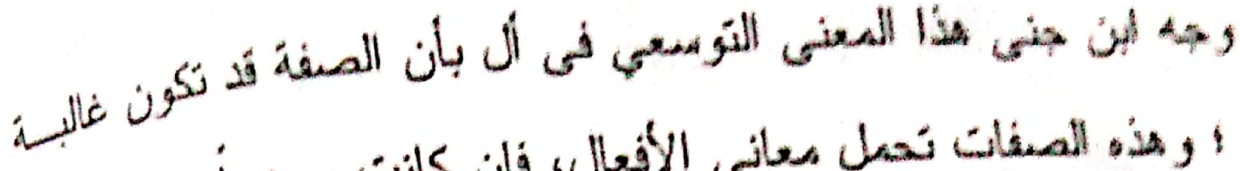

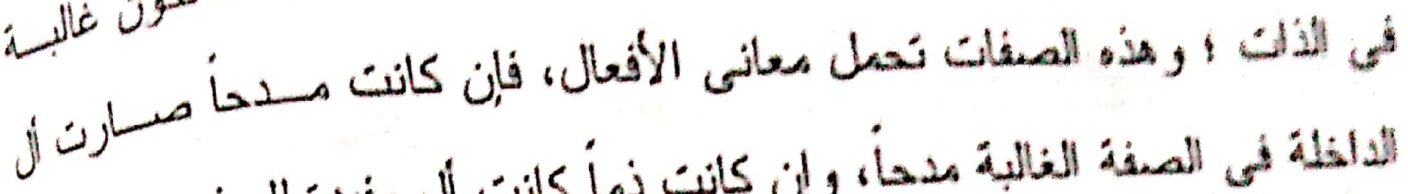

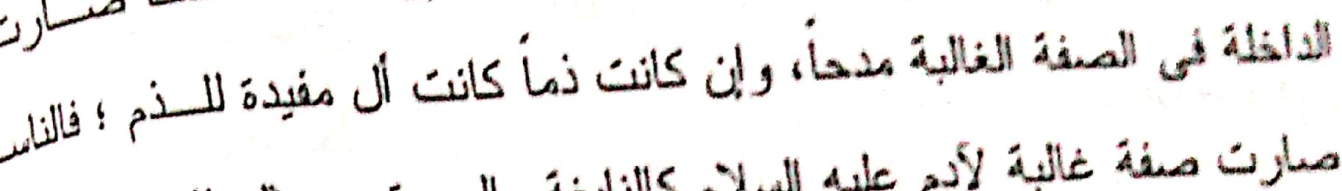

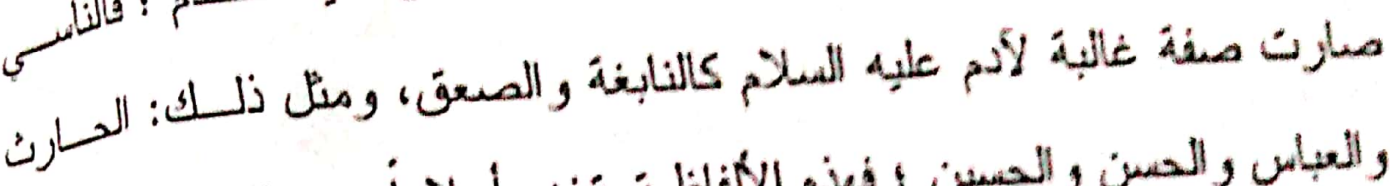

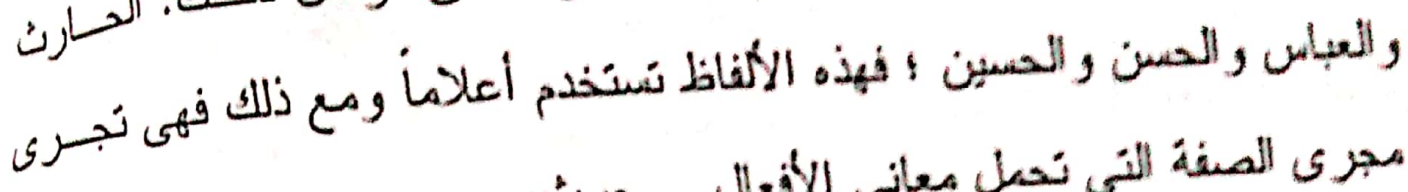

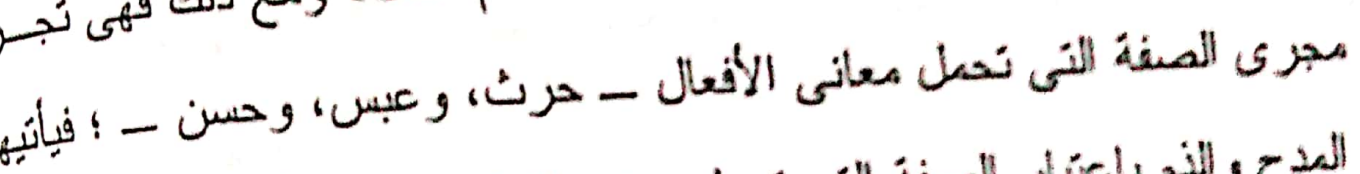

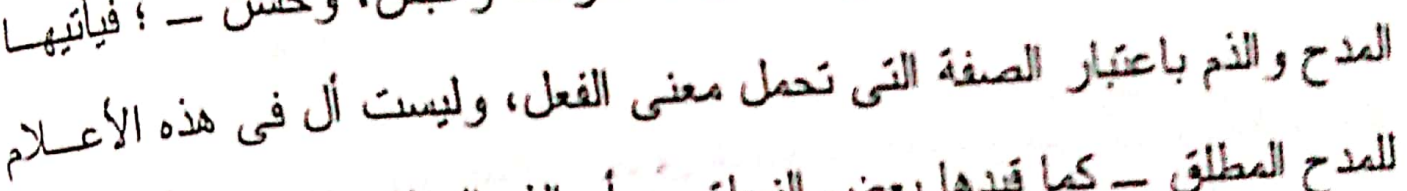

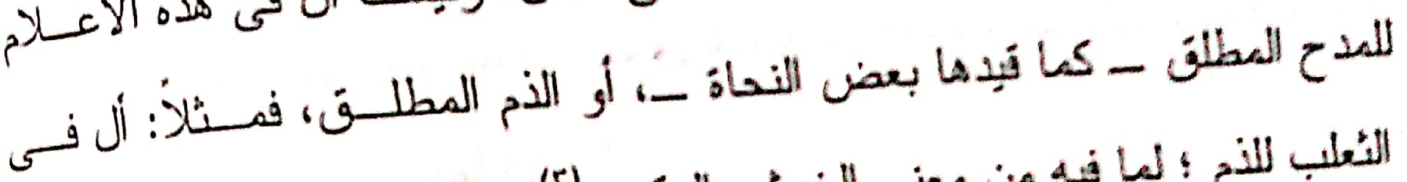

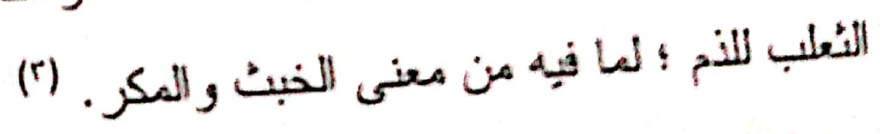

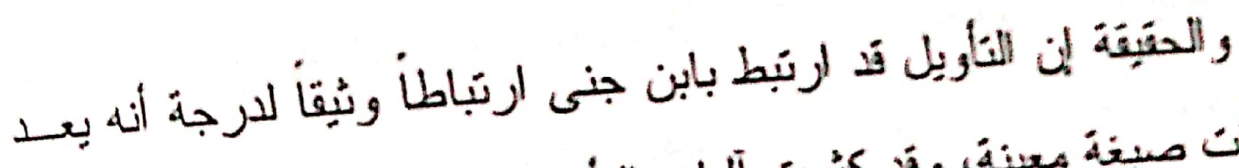

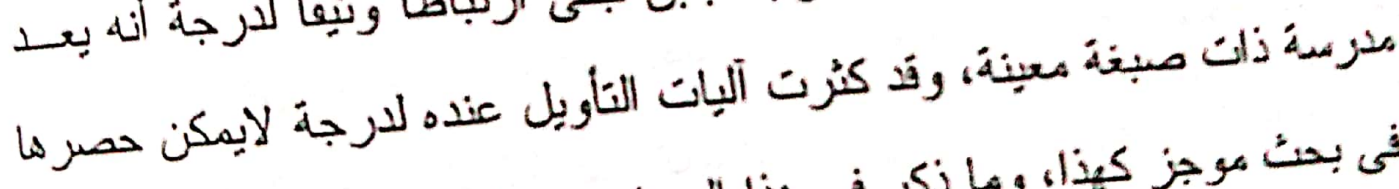

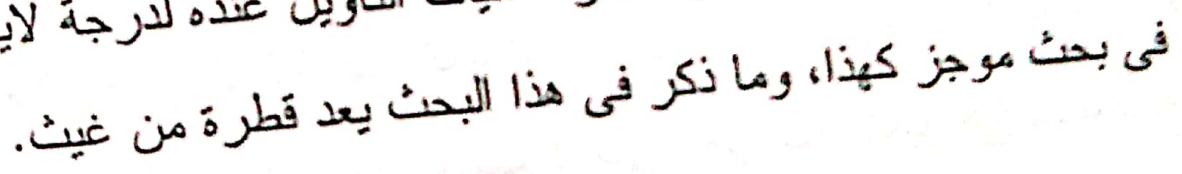

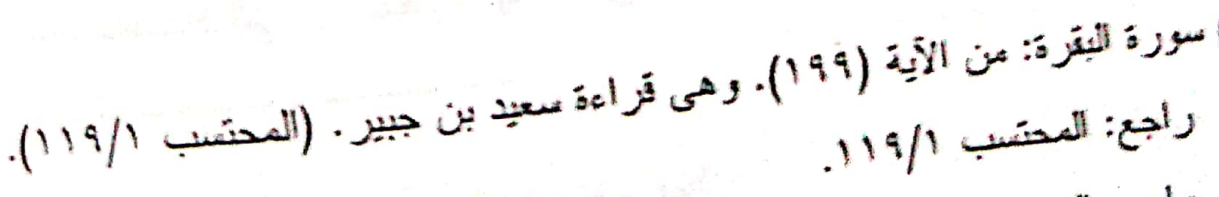

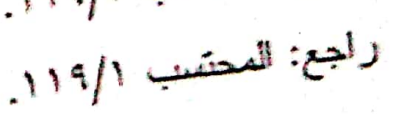




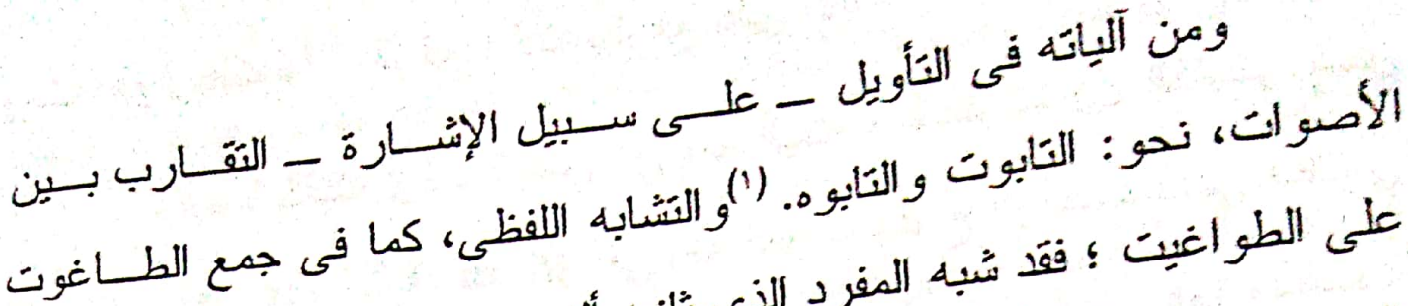

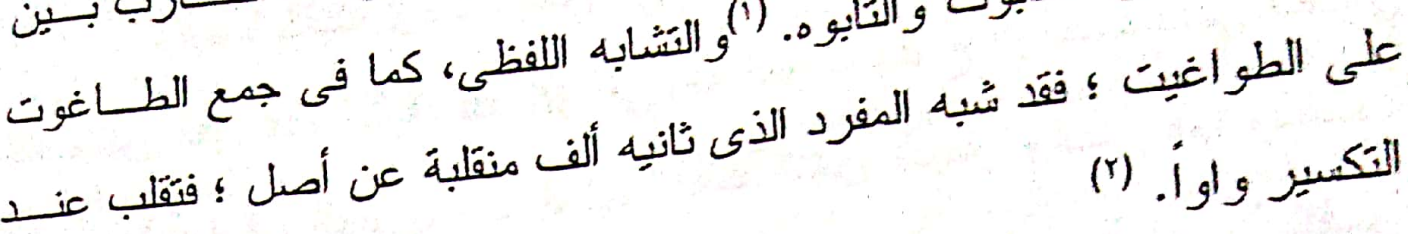

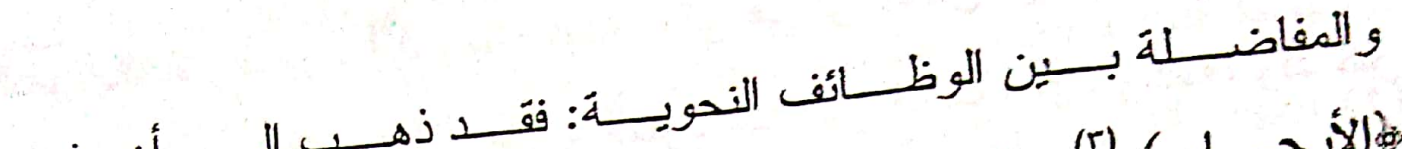

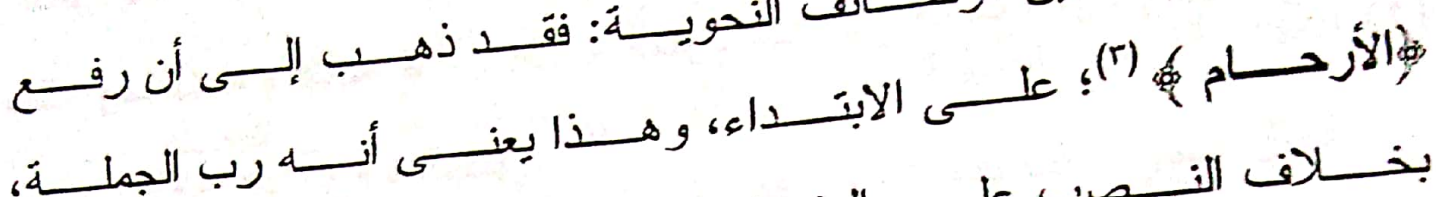

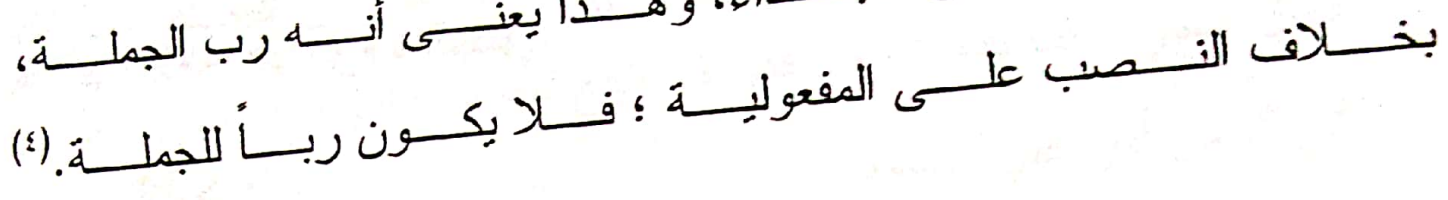

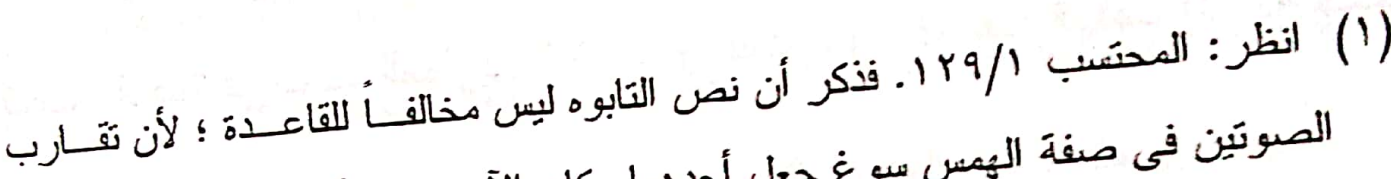

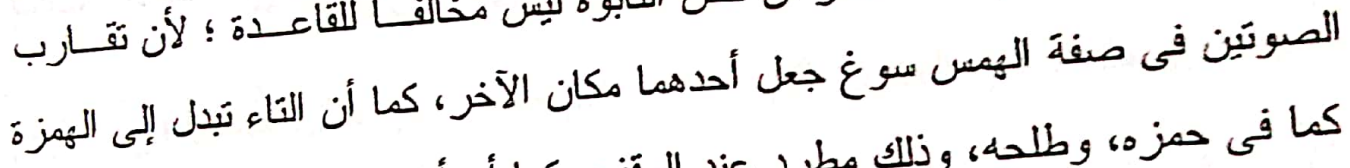

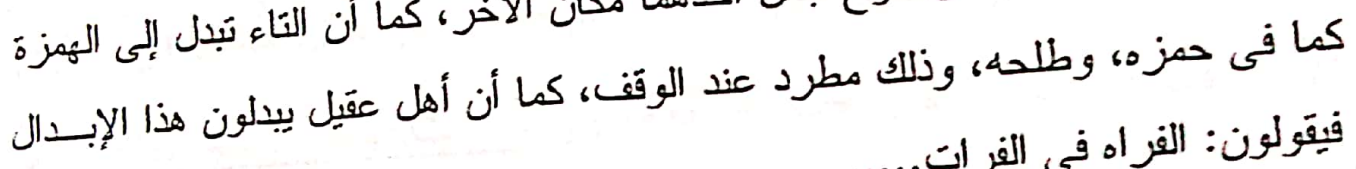
فَيَّلون: الفراه فى الفرات......

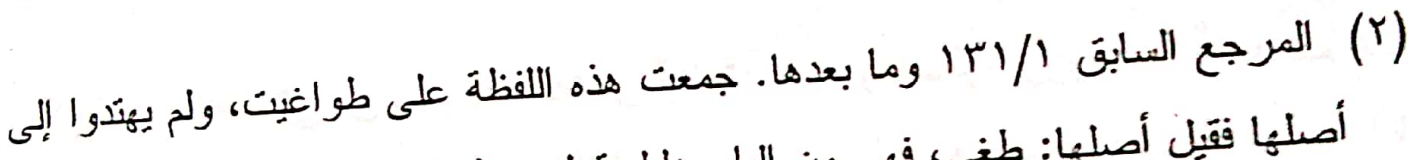

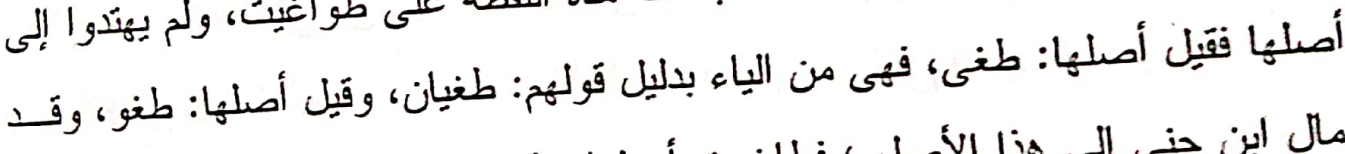

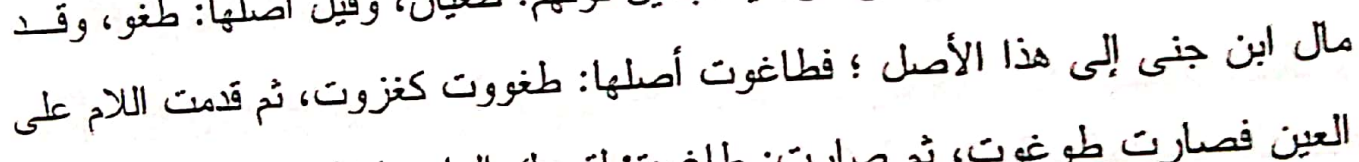

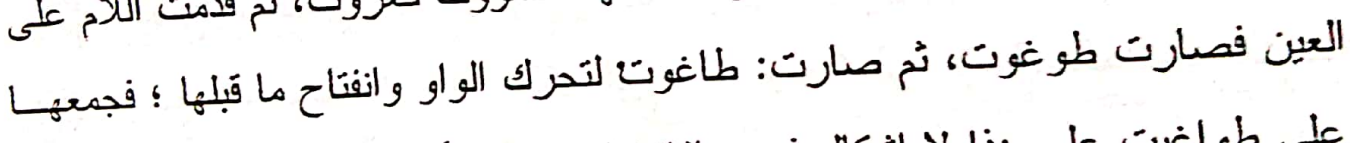

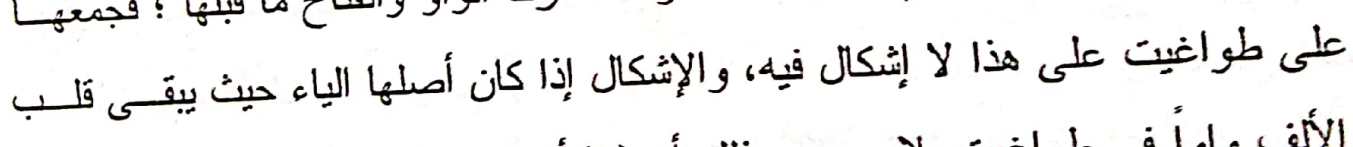

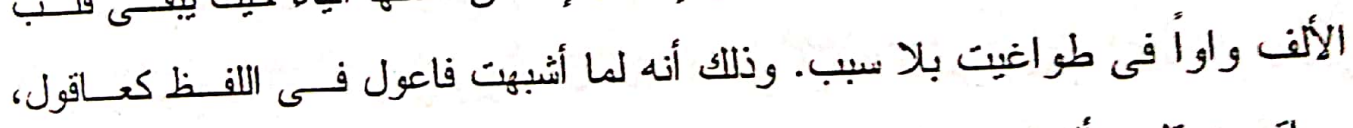

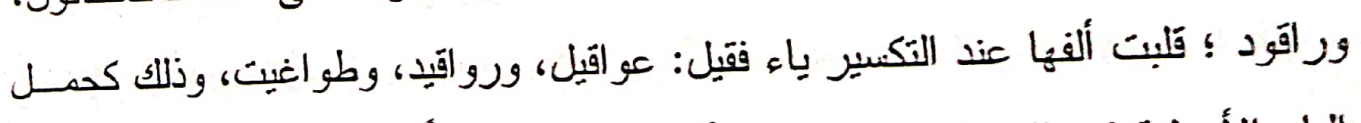

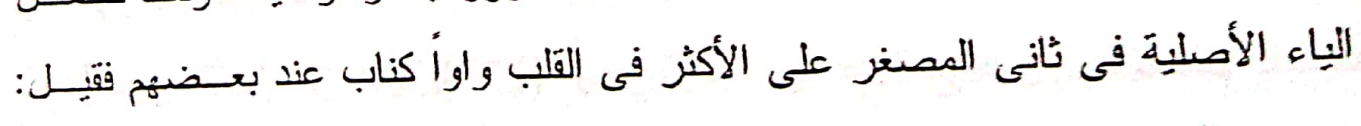
نويب... إلخ.

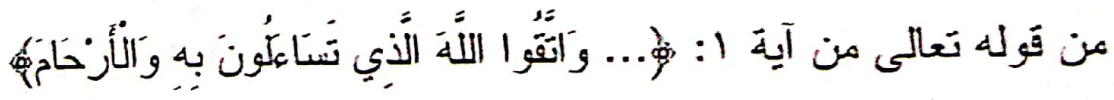

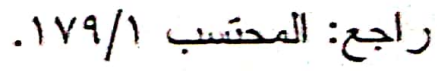




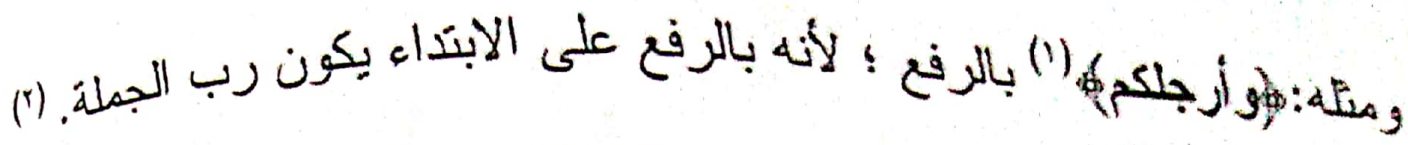
وأيضاً كانت إرادة الجنس من أهم آلياته ؛ فقـد نسأول الكنبر

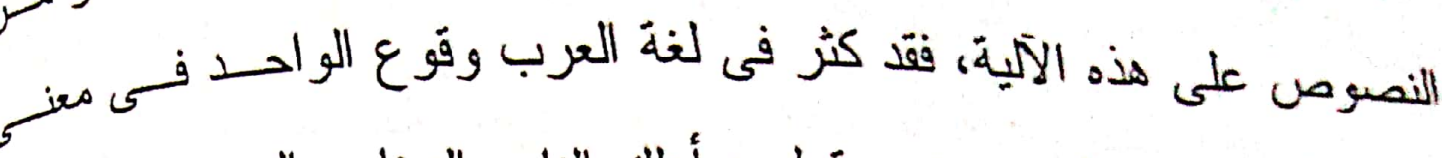

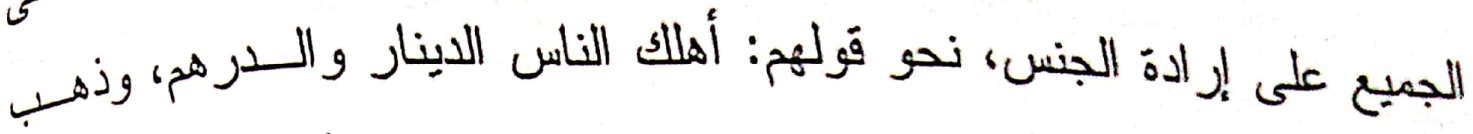

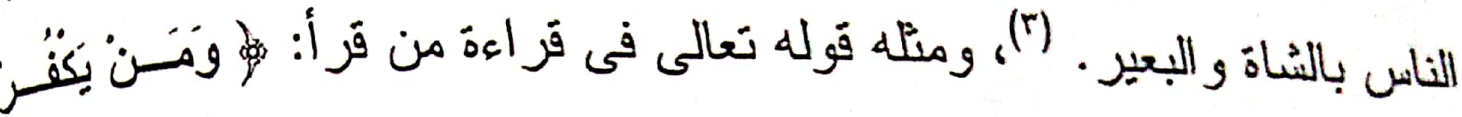

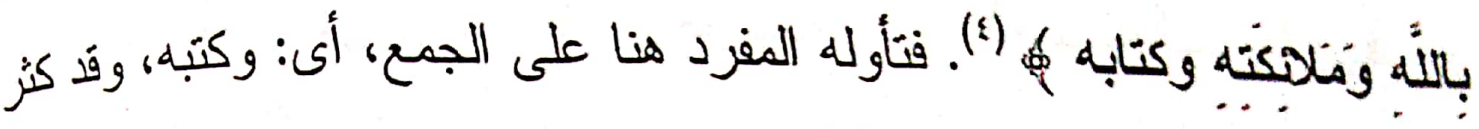

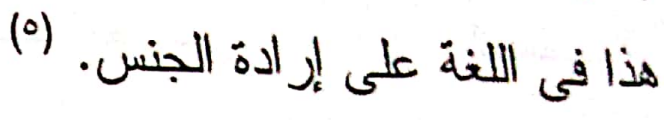

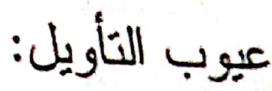

كما أن للتأويل ميزة فى رد المخالف إلى القانون العام والغالب ودخوله تحت القاعدة فى ثُب المطرد لا الشاذ أو النادر ، ورغم هذا الهذف إلا أنه كسان

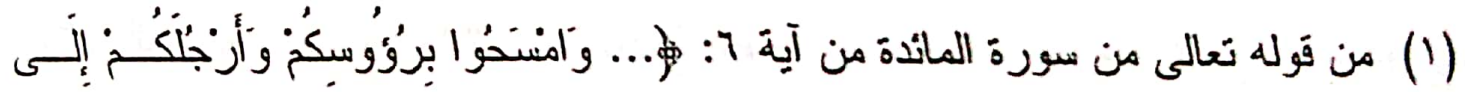

$$
\text { الكتبينئية }
$$

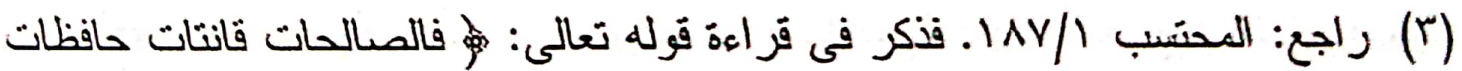

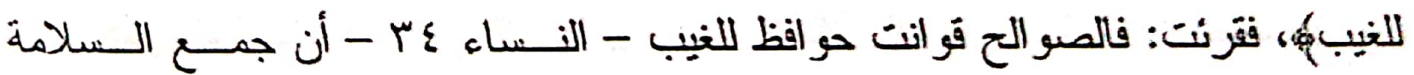

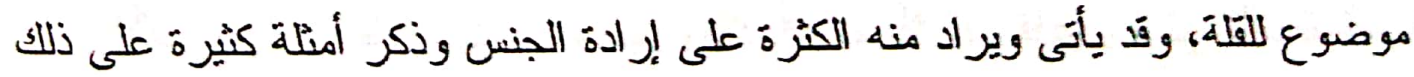

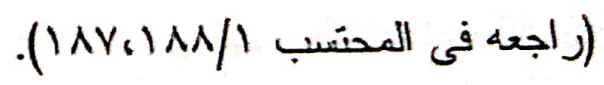

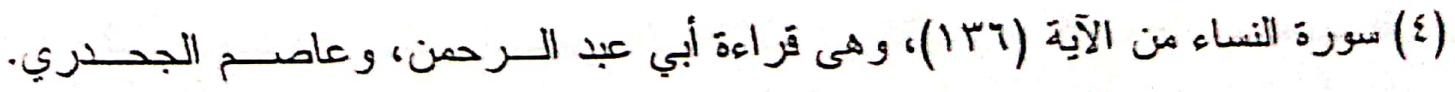

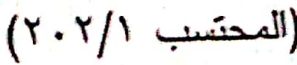

$$
\begin{aligned}
& \text { راجع: المحتسب /r/r.r. }
\end{aligned}
$$




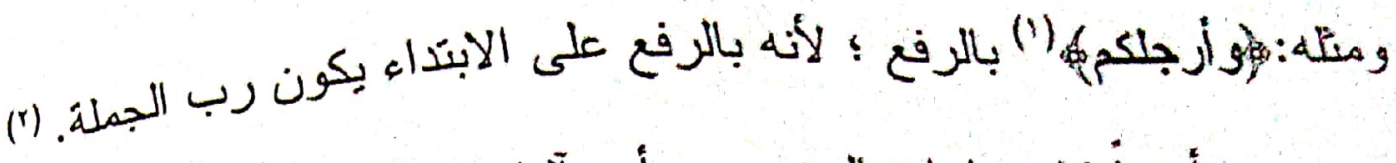
وأيضنا كانت إر ادة الجنس من أهم آلياتها ؛ فقـد بـأول الكني.

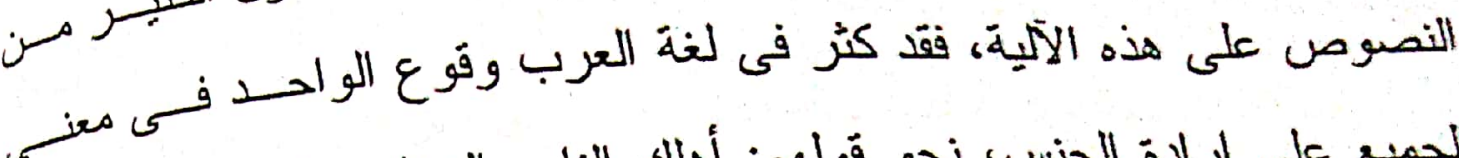

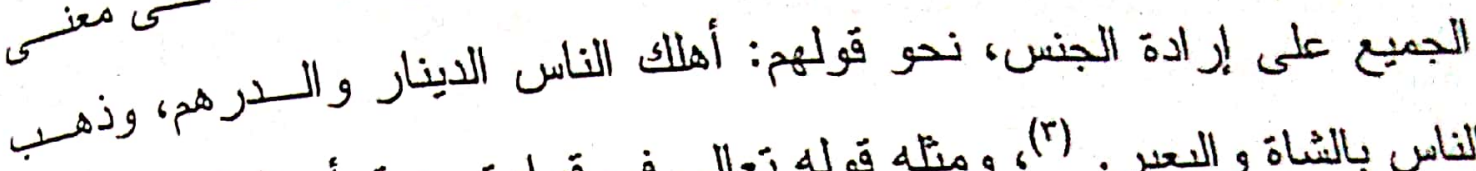

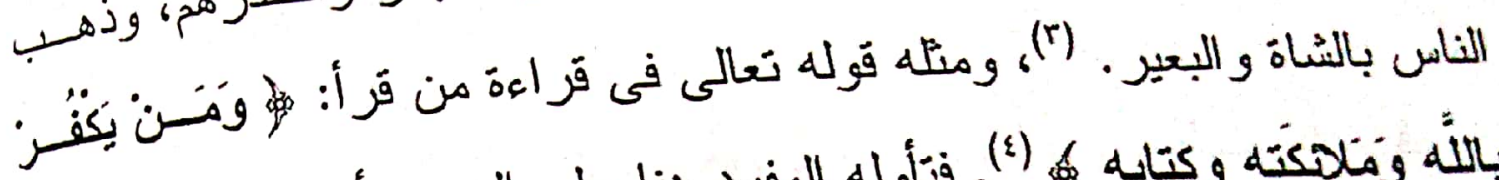

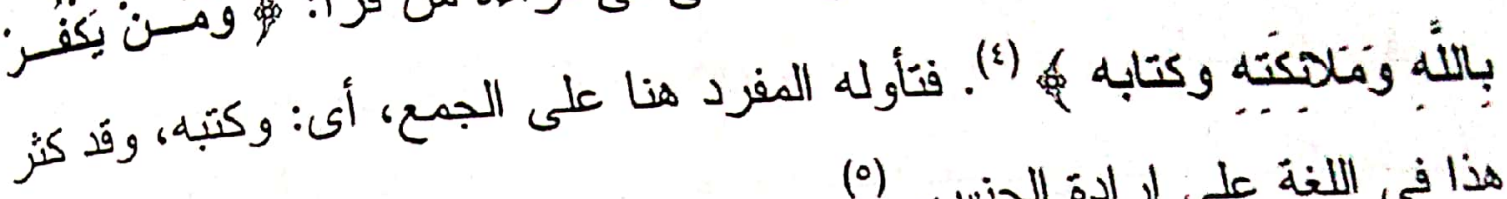

هذا فى اللغة على إرادة الجنس. (0)

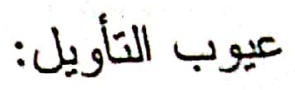

كما أن للتأويل ميزة فى رد المخالف إلى القانون العام و الغالب ودخوله

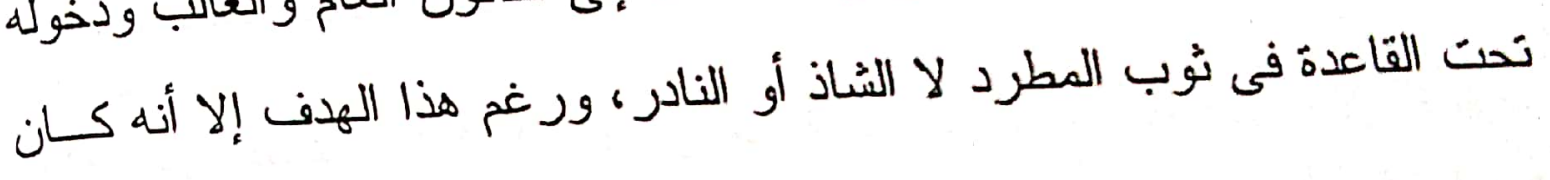

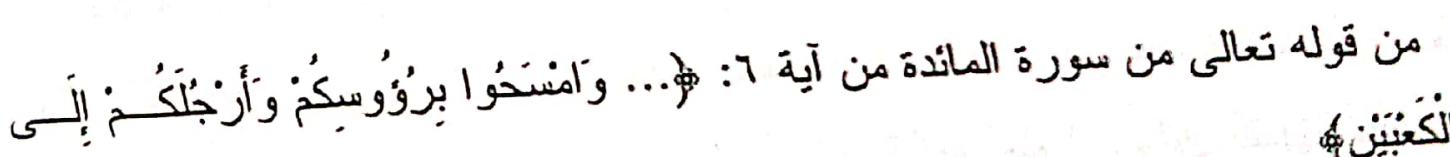

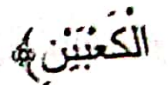

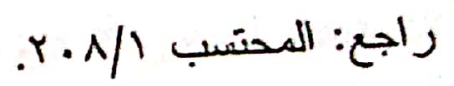

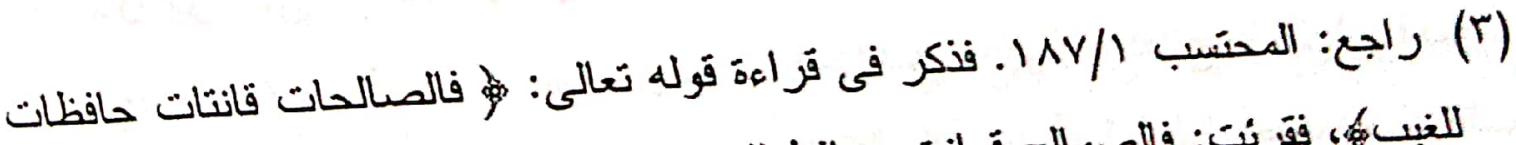

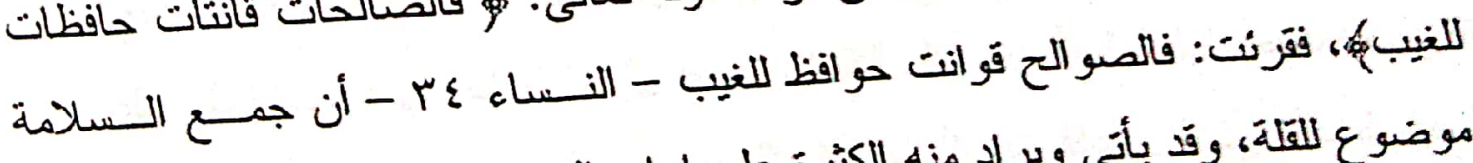

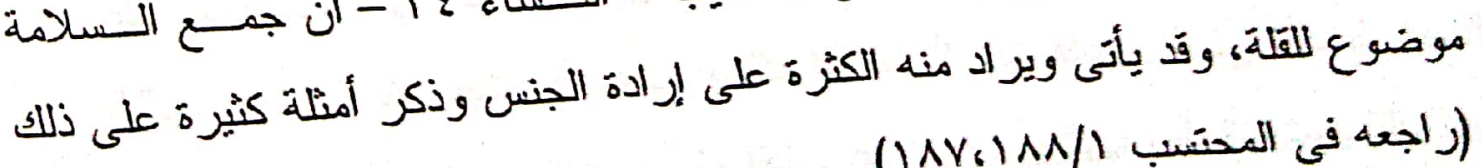

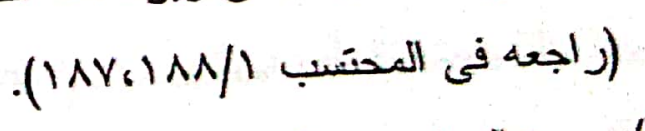

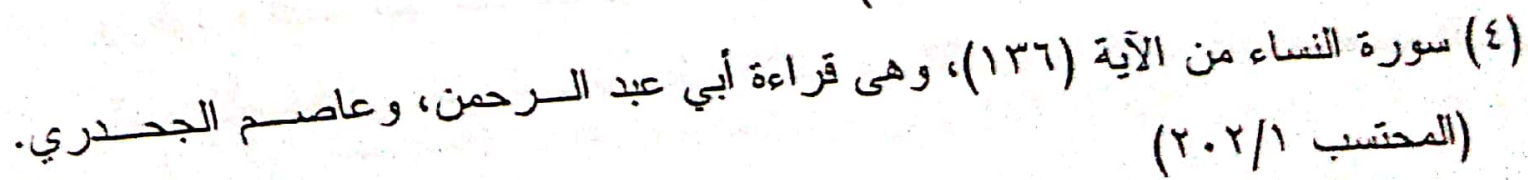

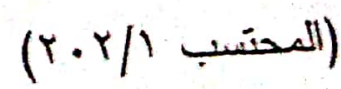

$$
\begin{aligned}
& \text { راجع: المحتسب / r r. }
\end{aligned}
$$


له عيب فى المسلك، وقَّح فى السالك، ومأخذ فى المنهج. فمسن عيسوب هـــه

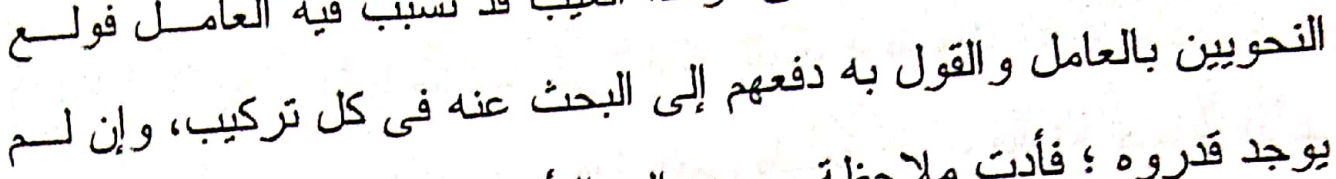

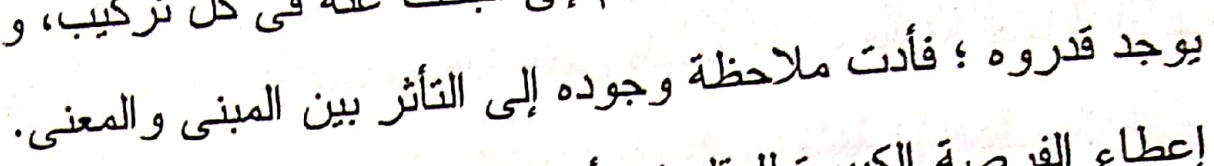

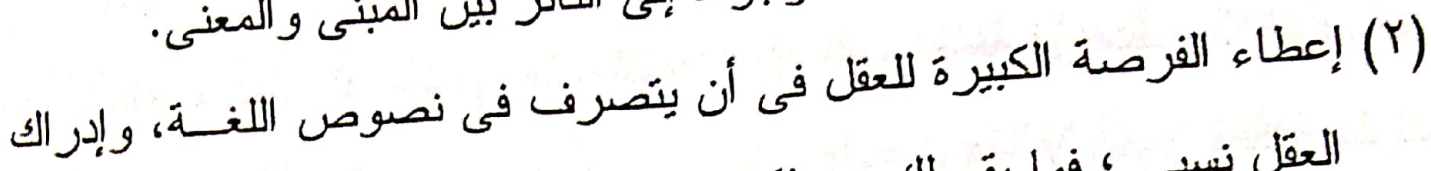

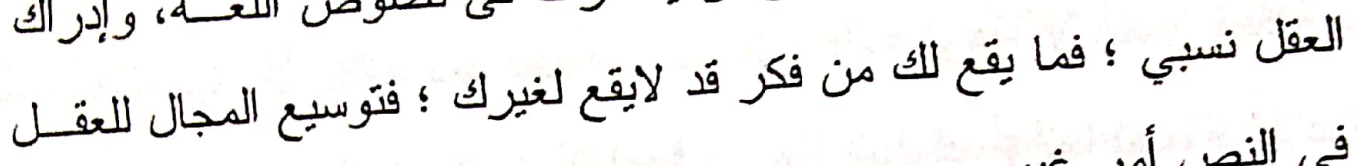
فى النص أمر غير محمود.

(r) عدم تحديد دور العقل أمام النص الذى يمكن أن يكون مخالفا، فبدلأ من أن

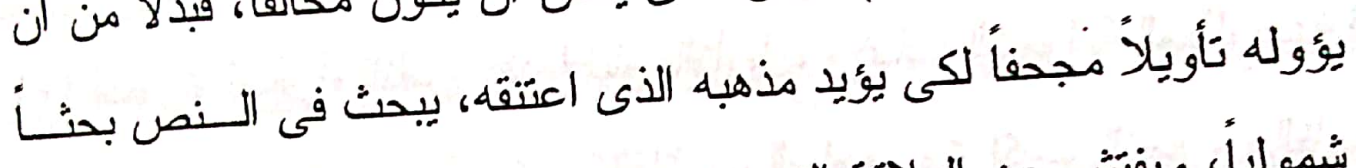

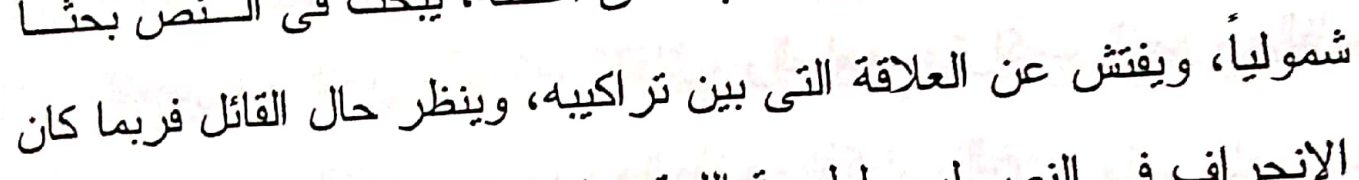

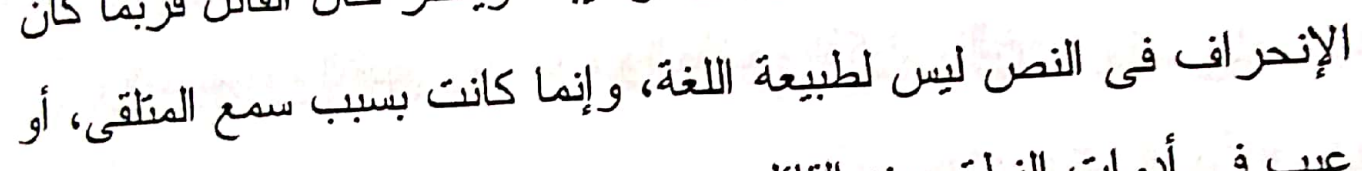
عيب فى أدوات النطق عند القائل. (ع) غياب المنهج السليم فى التأويل ؛ فهذه الظاهرة قَ ارتادها أغلب النحويِن،

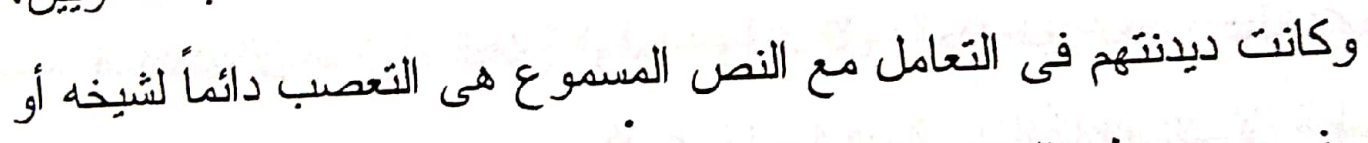

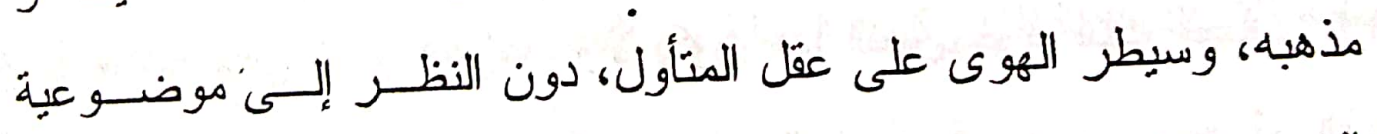
النص، ومثل هذا لا يخدم اللغة و النحو كظو اهر مسمو عة يجــب تحليلهــا، و الوقوف منها على قو اعد تتنظم و المسموع، وما تفرع من جزئيات توضع فى قو الب تقعيدية تثفق مع الأصل الذى تفرعت عنه. 


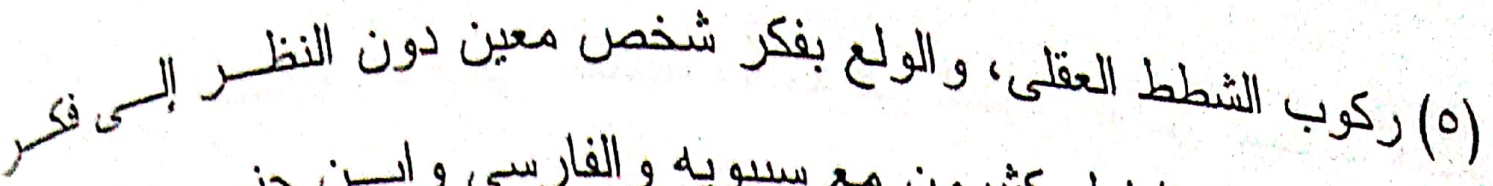

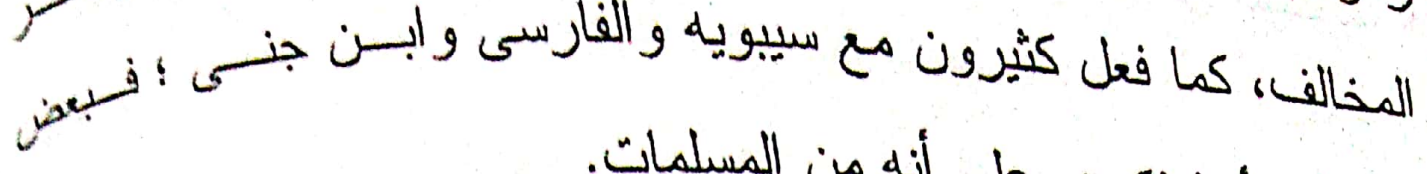
النحويين أخذ فكر هم على أنه من المسلمات.

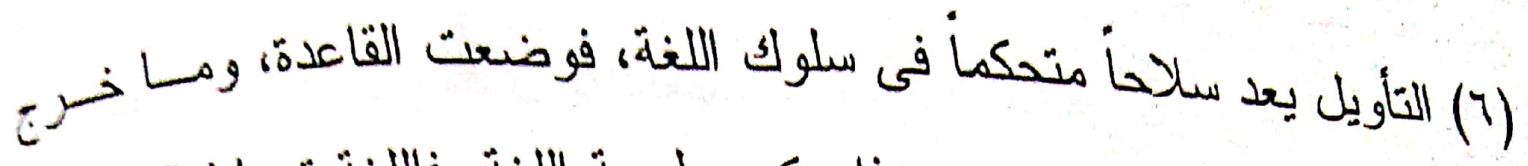
عنها تأولوه دون در استّه، وهذا عكس طبيعة اللغة، فاللغة تصاغ القاعذة هن أجلها وتدور القاعدة فى فلاك اللغة، لا أن تدور اللغة فى محسبط القاعسدة. فالقاعدة وتأويلاتها تعد سيفاً مسلطاً على اللغة. وهذا لا يجوز فاللغة سلوك إنسانى فلا يعقل أن ثتحكم القاعدة فى هذا السلوك، و إنما تصاغ القاعدة من هذا السلوك دون إغفال أى جزئية منه.

النظرة المجزأة للنص عند القيام بالتأويل، وغياب الشمولية المطلوبــة فـى (V) التعامل مع النص و أدو اته،، كالقائل، و السامع، وتز اكيب النص، و الظـــاهر و المضمر ، و التقديم و التأخير، و الحذف و الذكر ... إلخ

(^) التعامل مع النص بمستوى واحد من مستويات اللغة، دون النظر إلى طبيعة

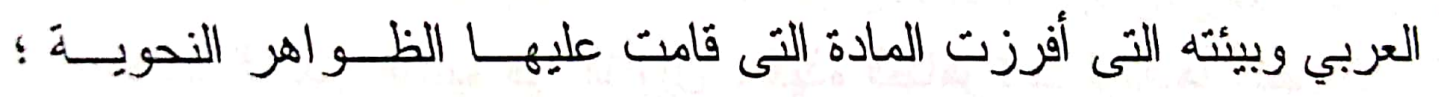

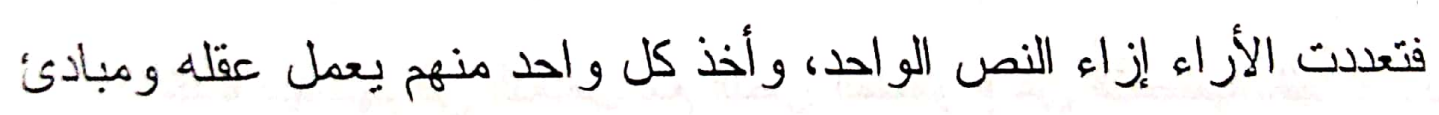
مذهبه حتى تقوى دعائمه، ولا يكون هذا النص خرقاً لتلاك المبادئ ؛ فكان

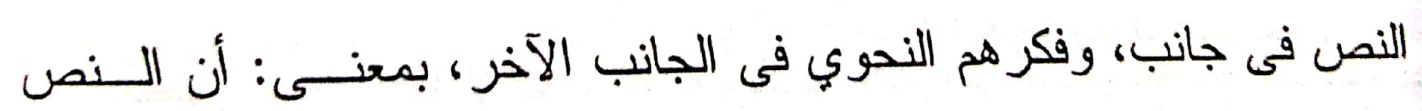

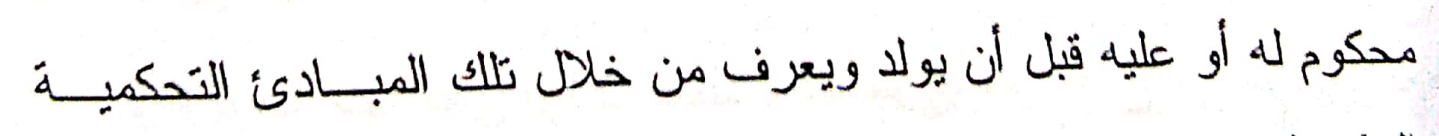
المذهبية. 


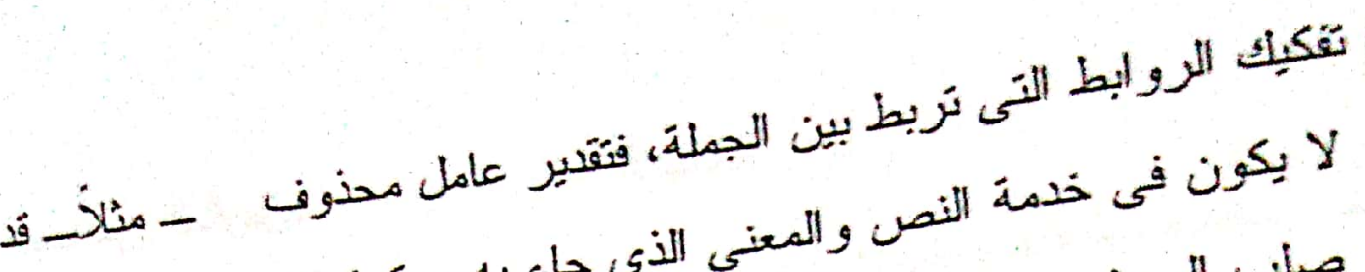

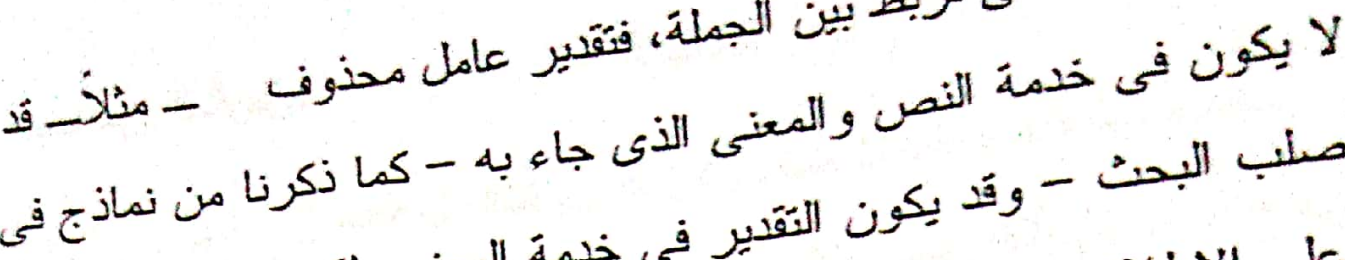

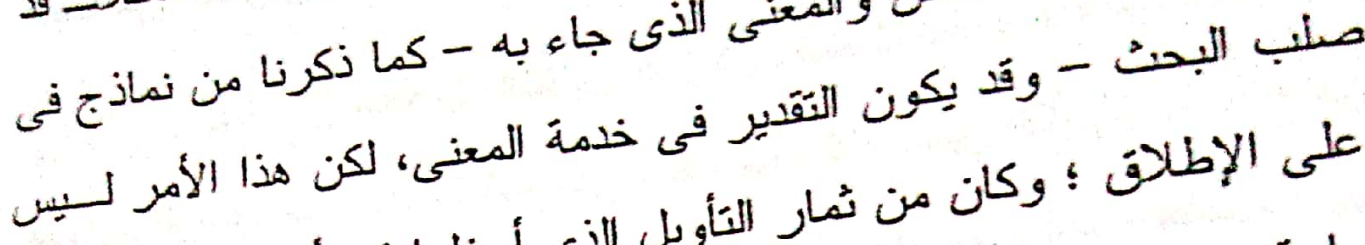

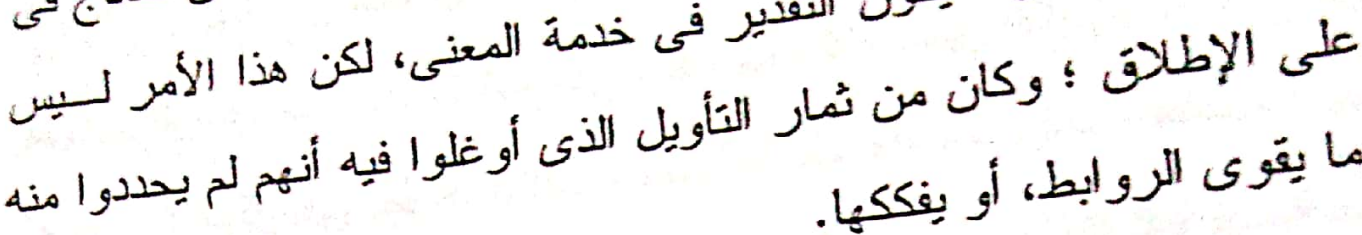
ما ينقوى الرو ابط، أو يفككها. (·) غياب المعيار النتأويلى الذى يحكم المتأول، فلم يكن للتأويل بداية و لا نهايةِ

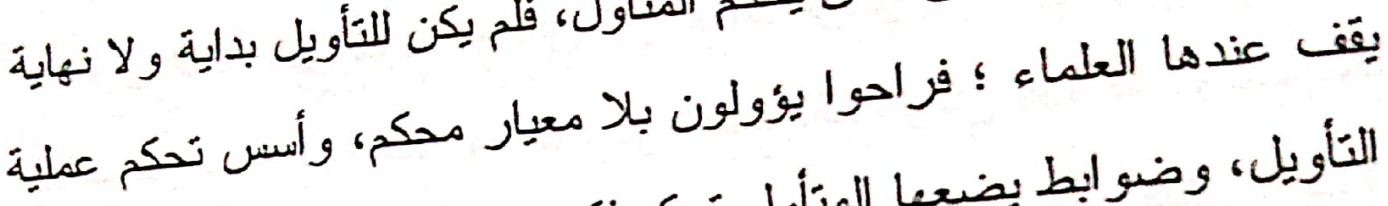
التأويل، وضو ابط بيضعها المتأول تحكم فكره و عقله.

فر اح الو احد منهم يِبِح فى بحر العقل و القَرة الذهنية له حتى أنعسب

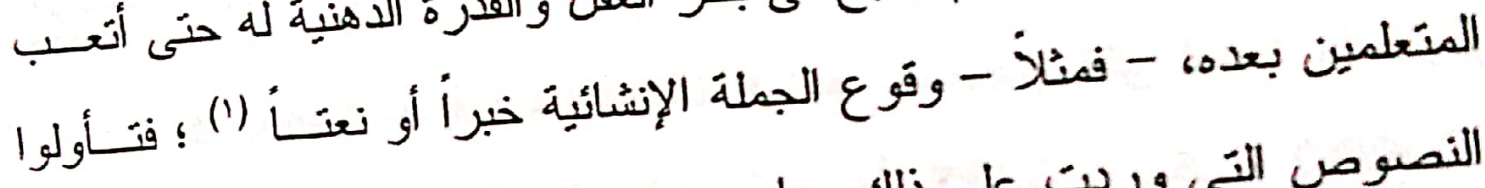

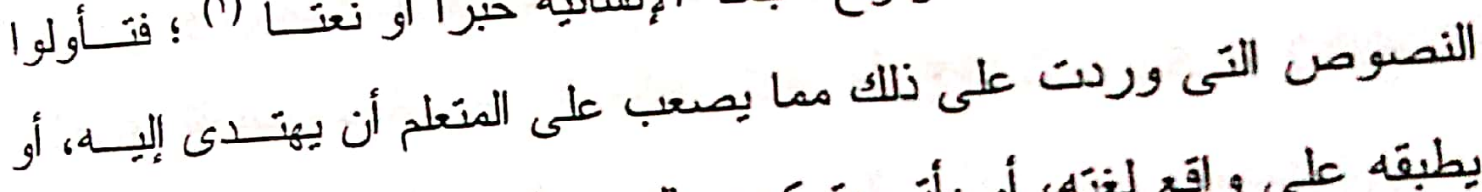

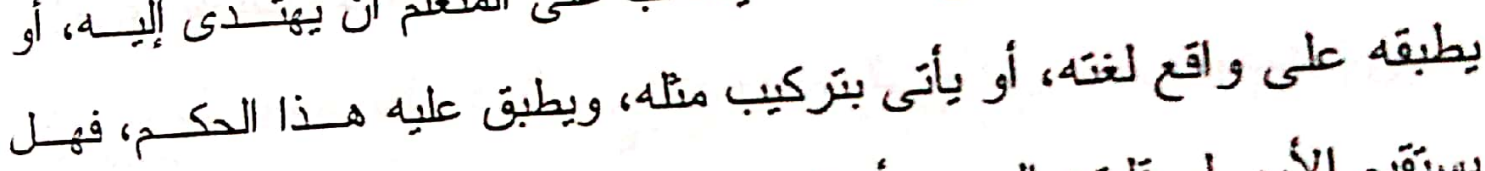

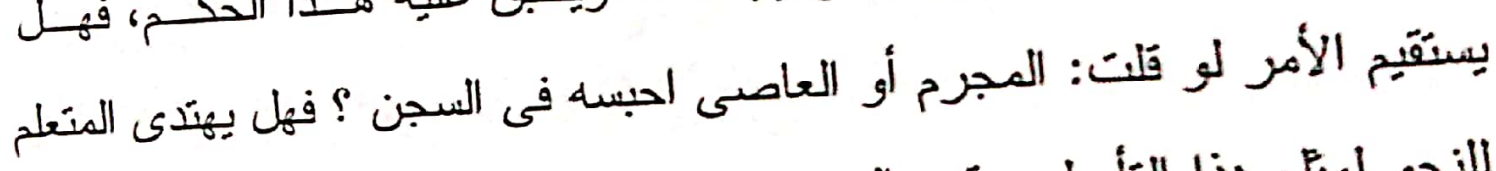

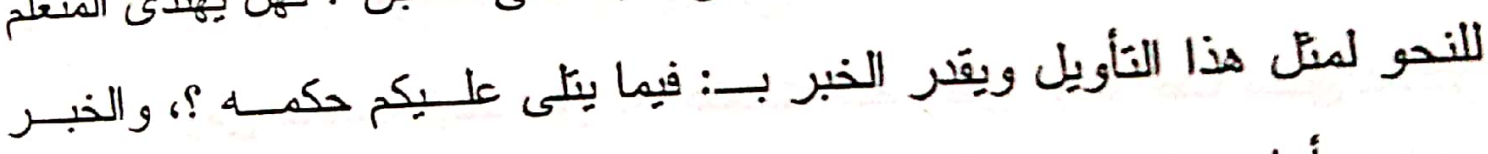
موجود أمام عِنيِه، وهو احبنه ؛ فحيث هو المقصود بالمعنى، و عليــه تمــت

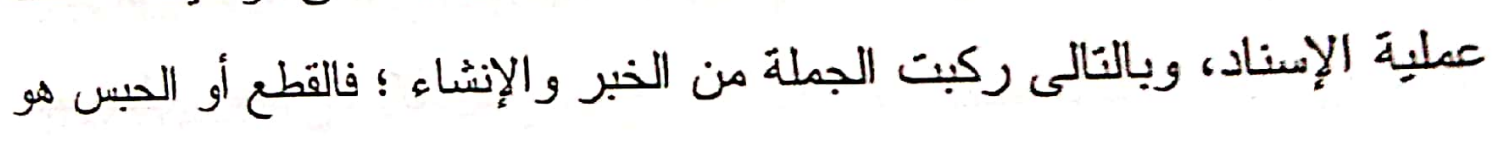
المعنى المقصود وبه تَت الجملة، وقامت عملية الإسناد.

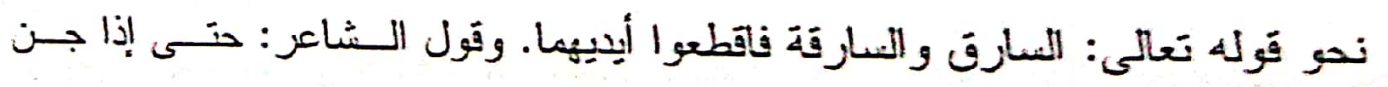

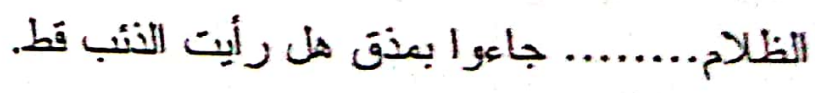


الحق إن محاسن التأويل كثيرة ويصعب حصرها، أو حسصر جـزه منها، و النحاة لهم جه مشكور فى ذلك، وما أخذ على التأويل لا يقدح فى كونه

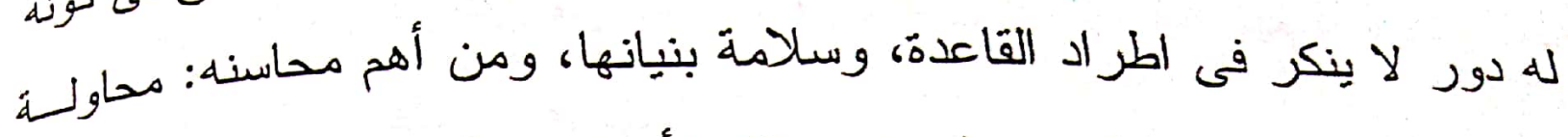

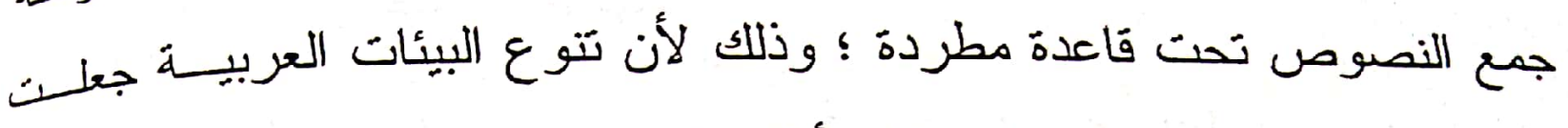
مستوى اللغة غير موحد - وإن كان أنقاها قريش - فكان لا بد مسن صسياغة القاعد من مستوى و احد، وتزك باقى المستويات، ولكن هذه المستويات تحمل من

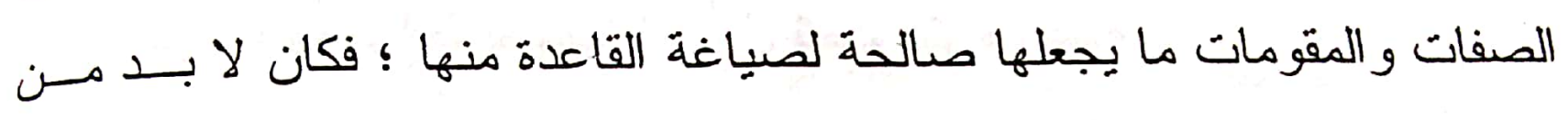
الاعنماد على مستوى وتأويل غيره حتى تتنظم المستويات حتى صرح القاعدة. ومن محاسنه ثقريب شقة الخلاف بين النحويين التى امنّت ردحاً من الزمن، وتقريب وجهات نظر المخالفين الذين دأبوا الخلاف، وكـلـ الخلافــات اعتمدت على وجهة نظر الناظرين ؛ فهذا نظر إلى ظاهر النص، وذاك إلى مسـا يرميه النص من معنى قَّ لا يدركه إلا خبير بالأمر.

ومن محاسنه أيضاً: أن به اعتمدت النصوص، وخرجت مسـن دائـــرة

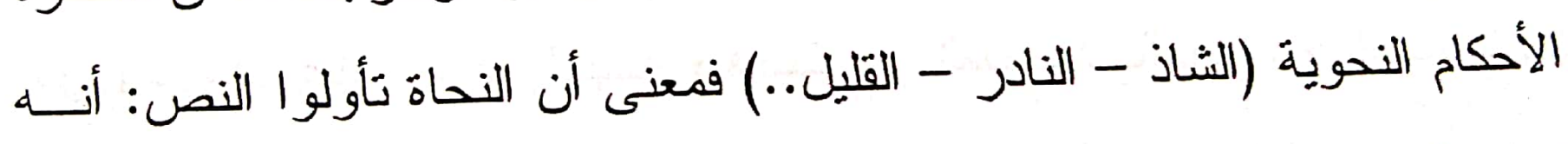
نص سليم وفصيح وذات بيئة سليمة.

و الخق إن محاسن التأويل كثيرة، وما ذكرته هو أشهر ها، و أغلبها، و لا يمكن حصر ها فى هذا المختصر ، ويكفينى الإشارة. 


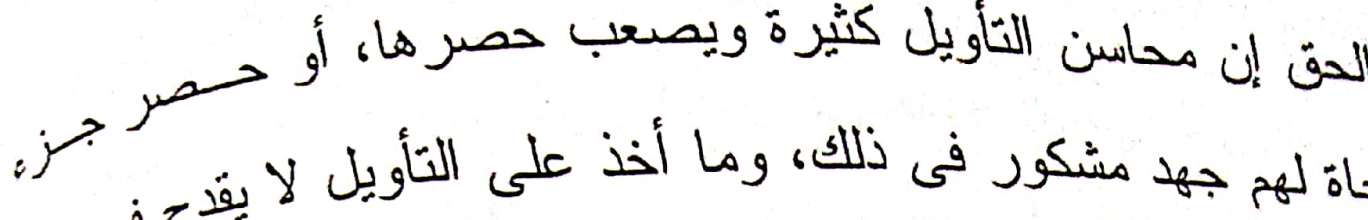

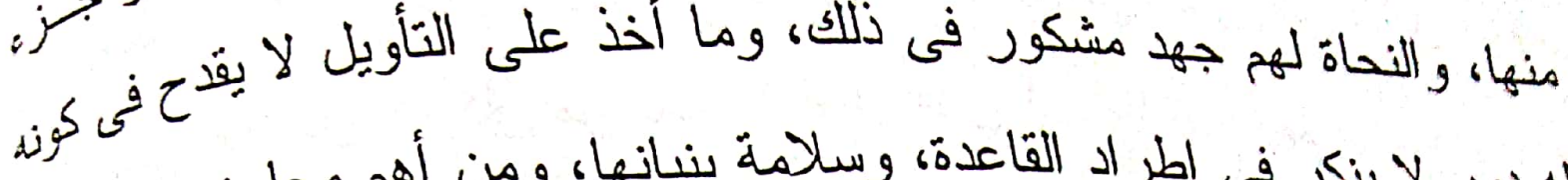
له دور لا بنكر فى اطر اد القاعدة، وسلامة بنيانها، ومن أهم محاسنه: محاولدة

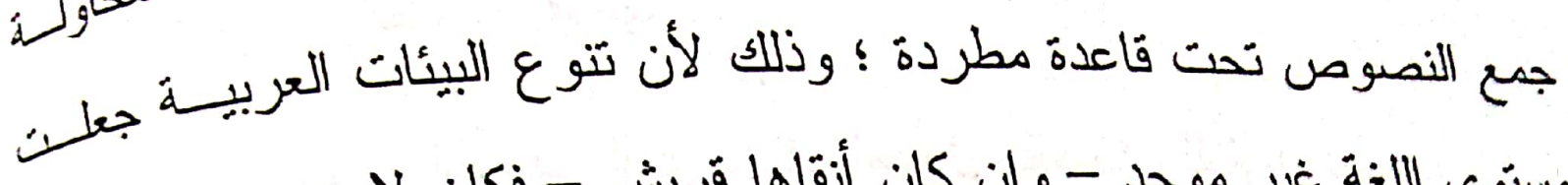
مستوى اللغة غير موحد - وإن كان أنقاها قريش - فكان لا بد مسن صسباغة القاعد من مستوى و احد، وتزك باقى المستوبات، ولكن هذه المستويات نحمل من

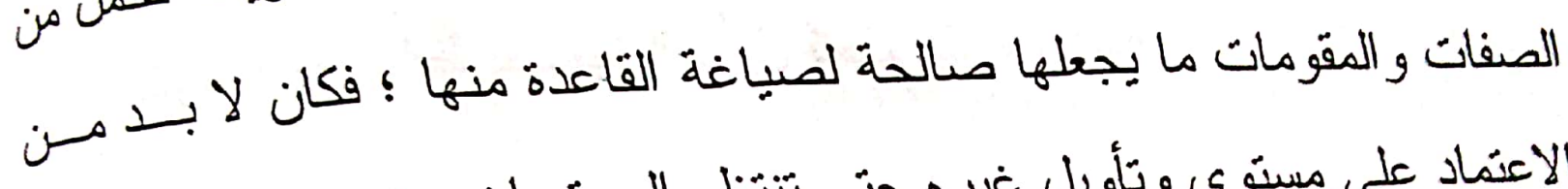
الاعتماد على مسنوى وتأويل غيره حنى تتنظم المستويات حنى صر ح القاعدة. ومن محاسنه ثقريب شقة الخلاف بين النحويين التى امتكت ردحاً من

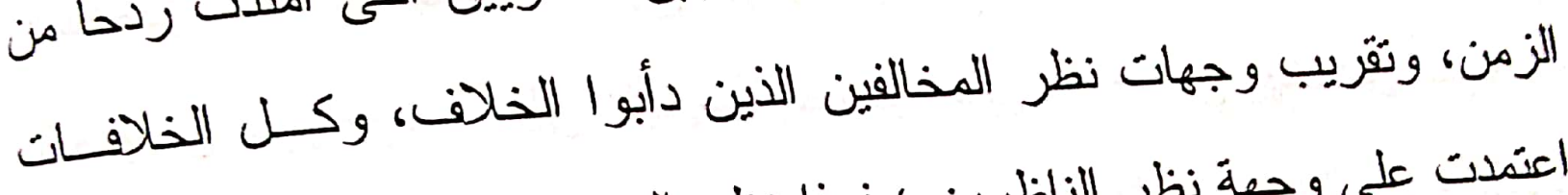

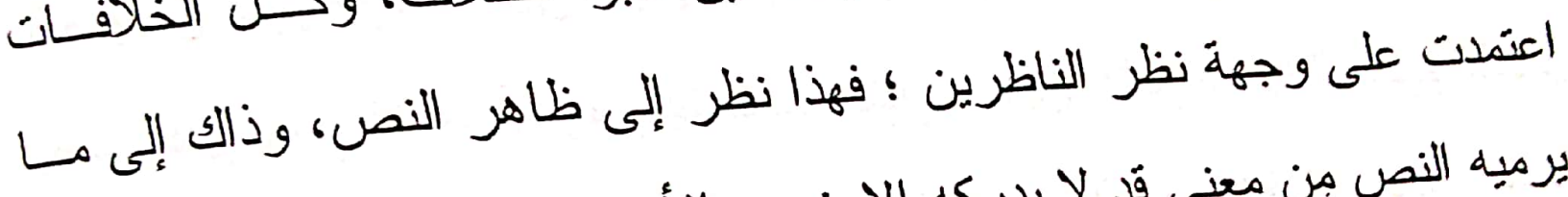
يرميه النص من معنى قد لا يدركه إلا خبير بالأمر.

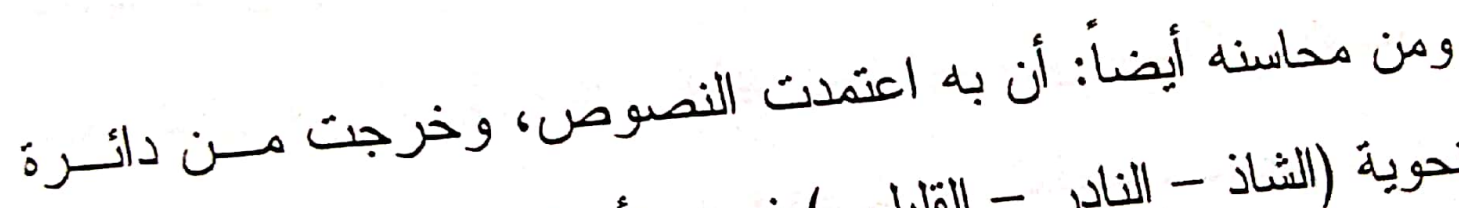

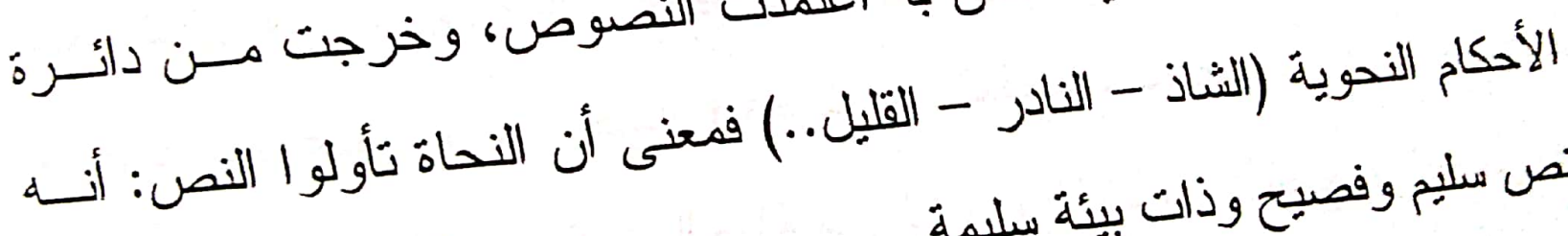
نص سليم وفصيح وذات بيئة سليمة.

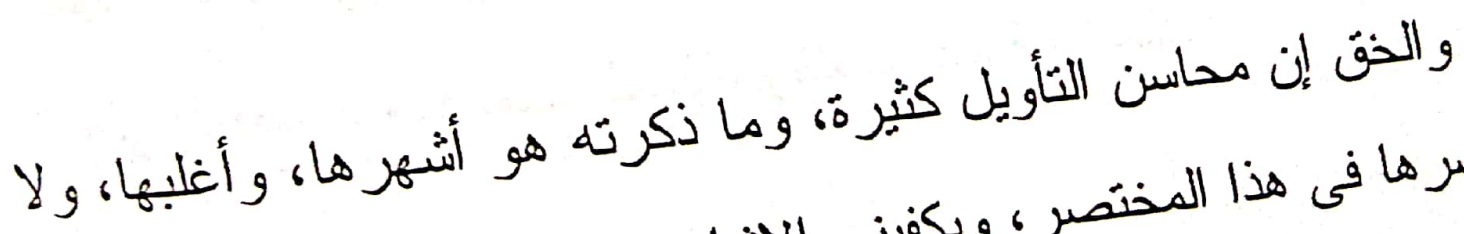
بيمكن حصر ها في هذا المختصر ، ويكفينى الإشارة. 


\section{النداتصة}

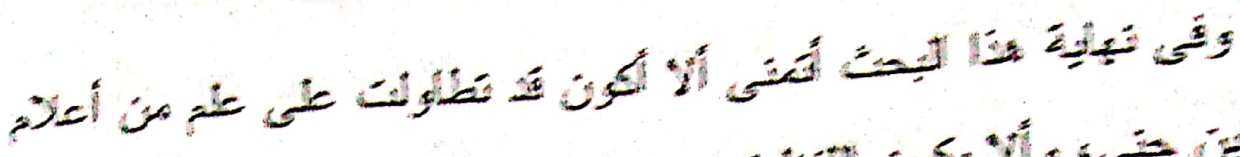

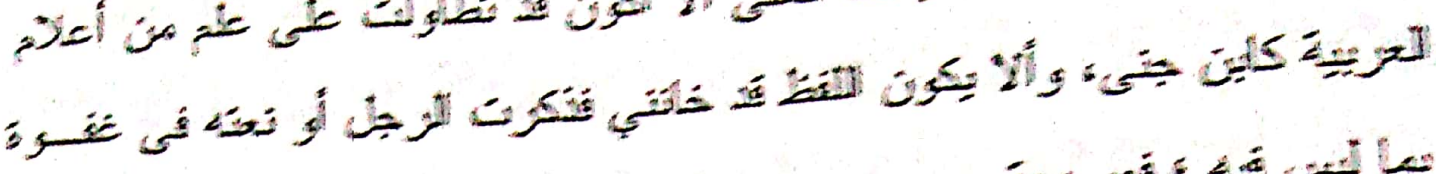

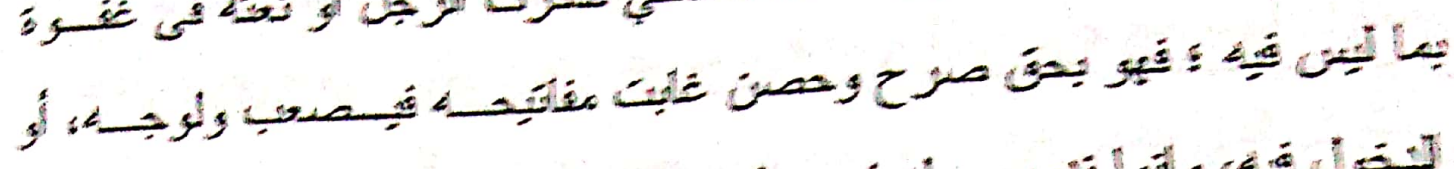

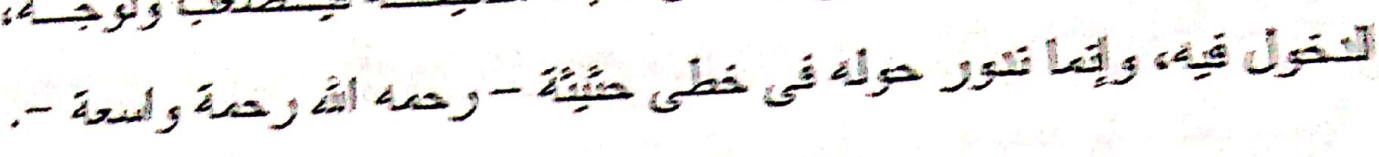

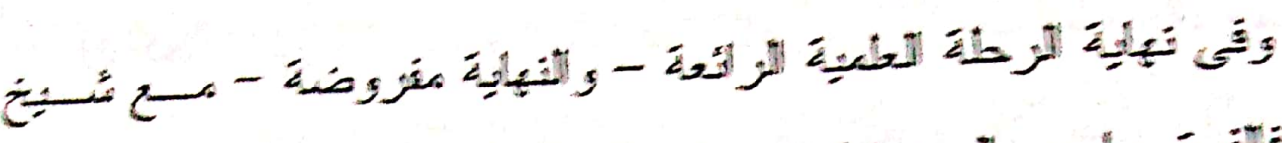

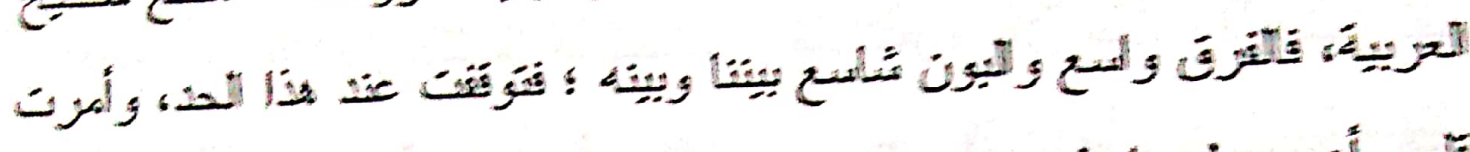

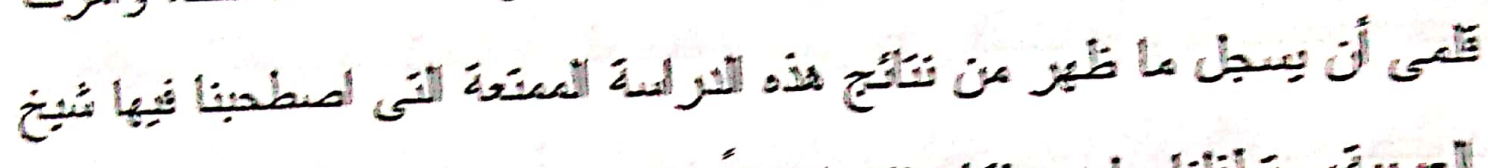

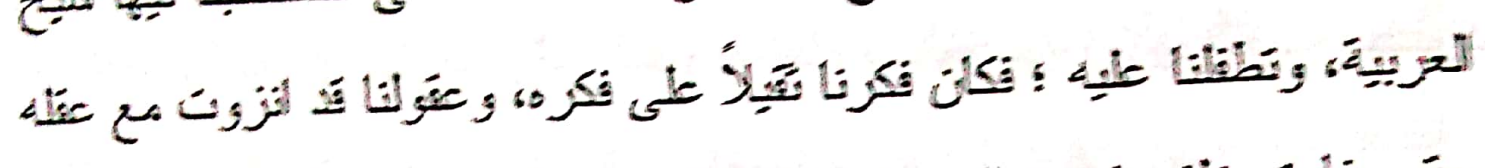

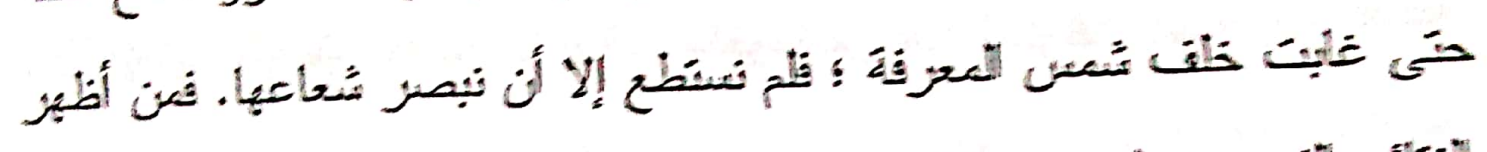

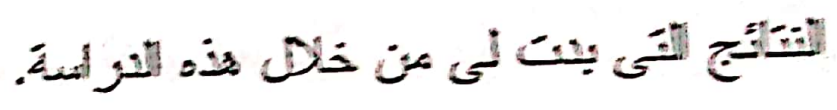

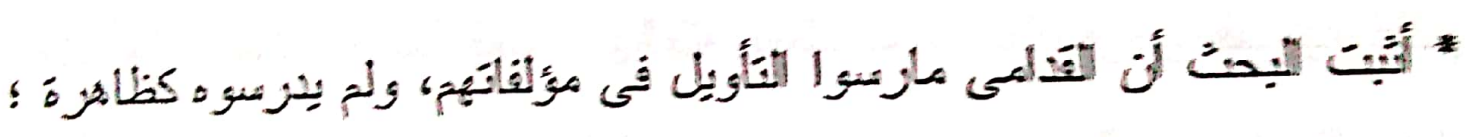

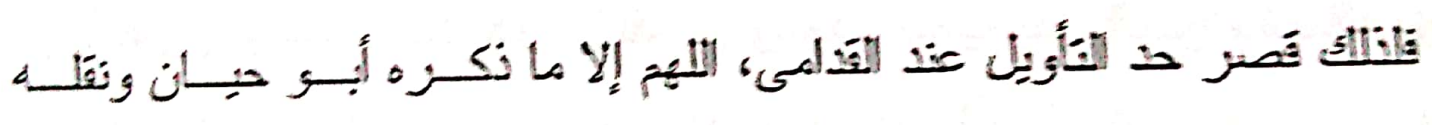
البيزئى عذب.

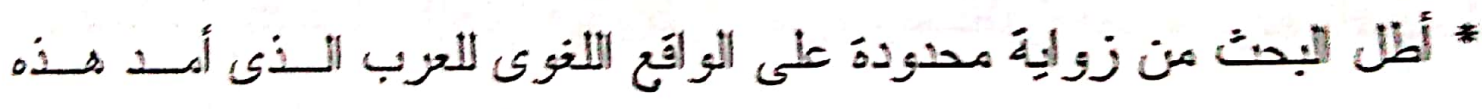

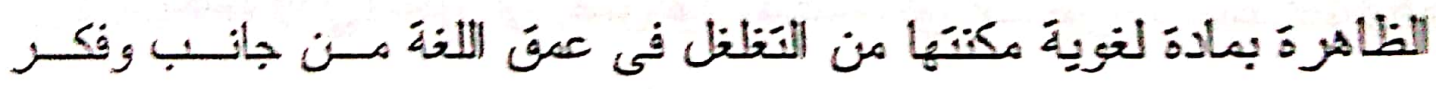
اللنوى من الجانب الآخز .

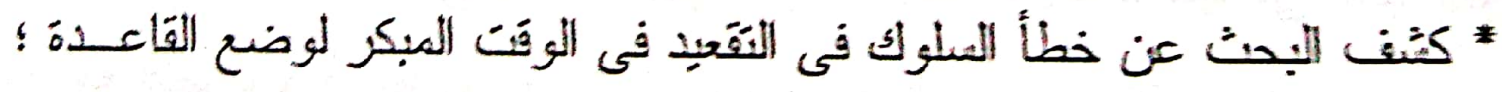

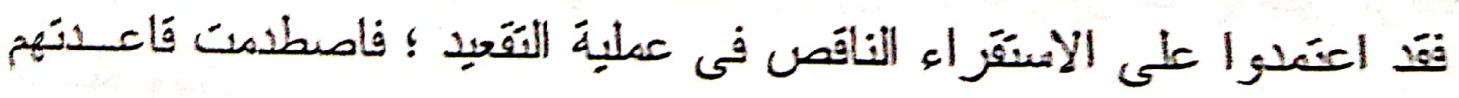

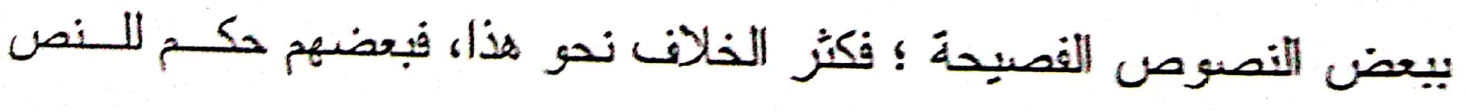




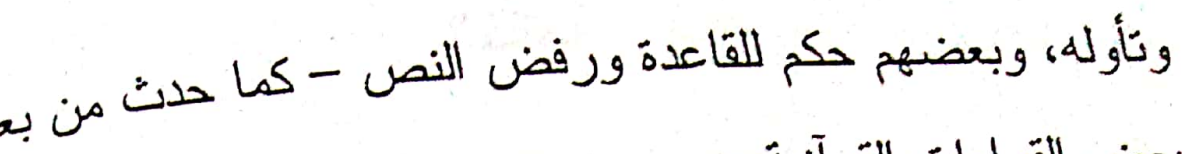

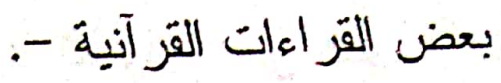

* الأو ائل قَّ جعلو اللغة و احدة فى عملية الثقعيد لهذا القن ؛ فلم بفرفوا ببن لغو.

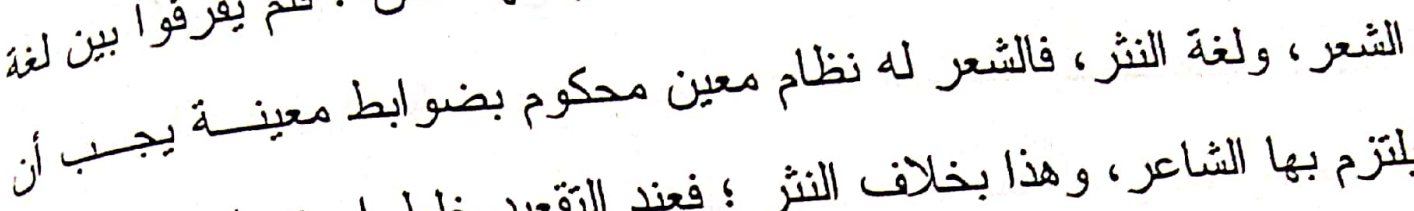

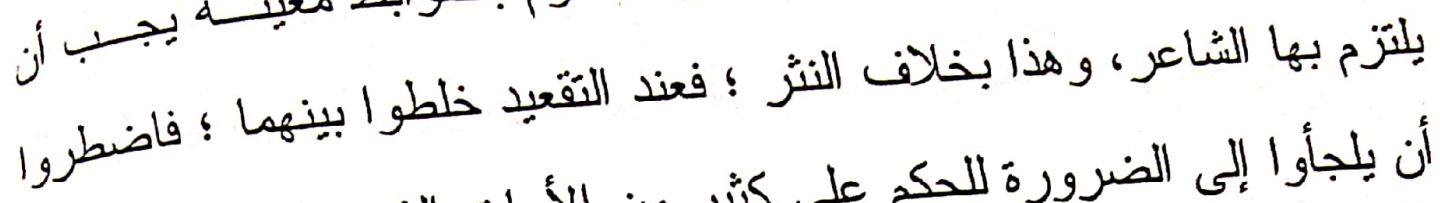

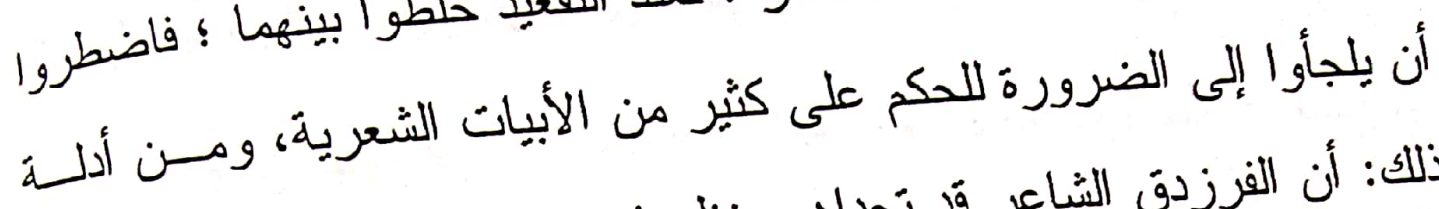
ذلاك: أن الفرزدق الشاعر قذ تحداهم ونظم شعره على خلاف قاعدتهم. فته

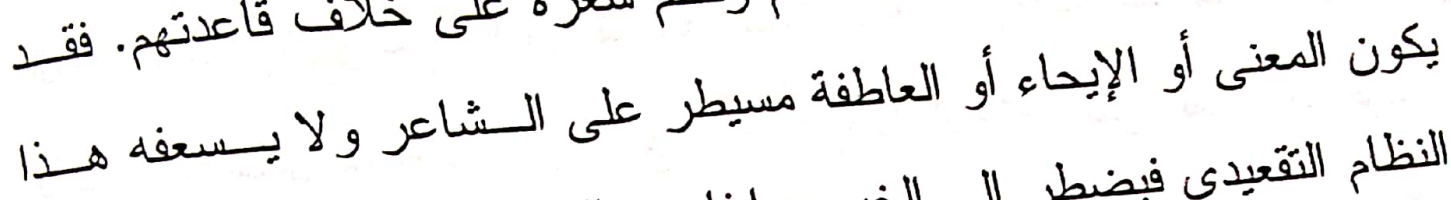

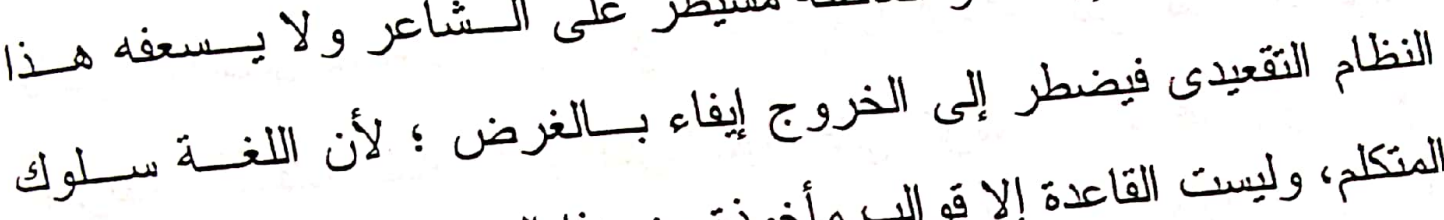

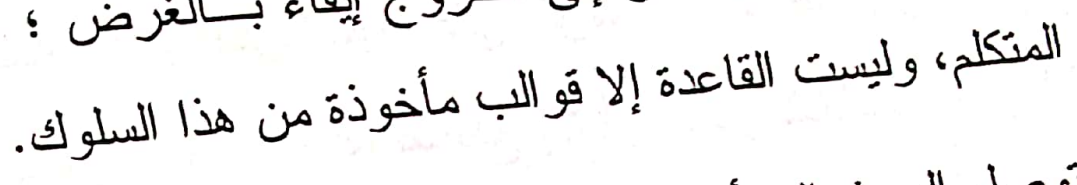
* توصل البحث إلى أسباب التأويل فى النحو العربى، وأرجع السبب إلى فضايا

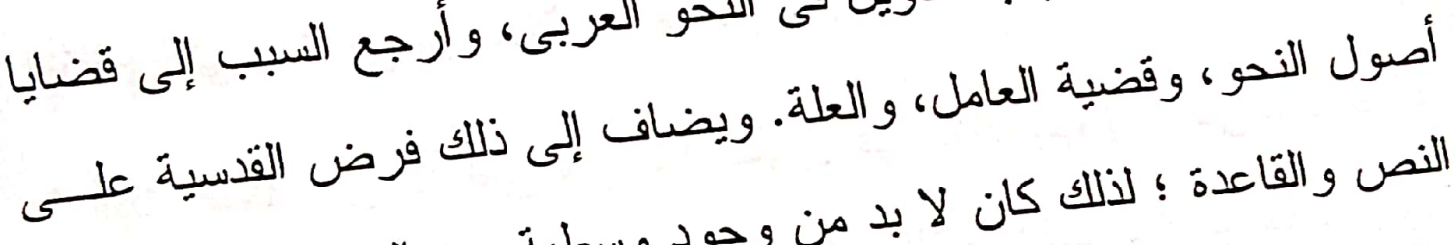

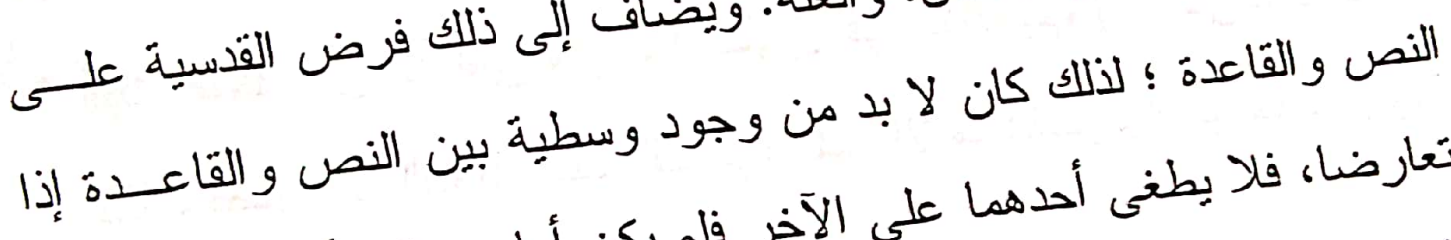

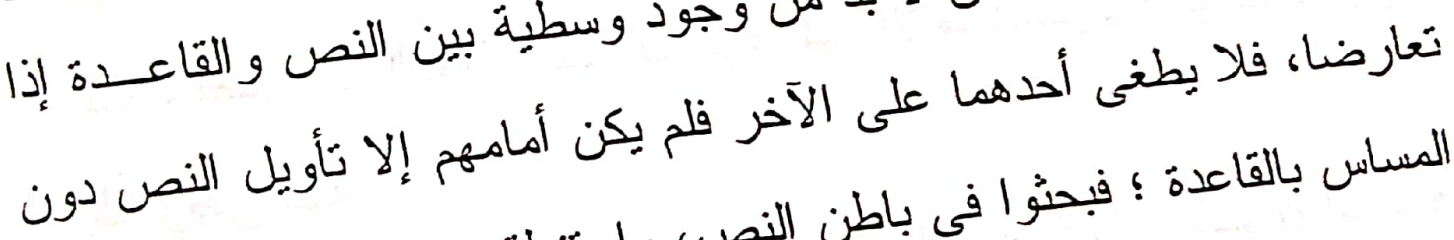

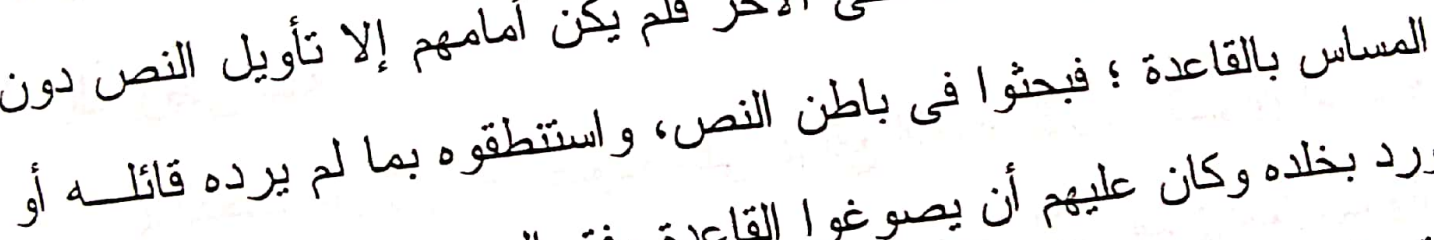

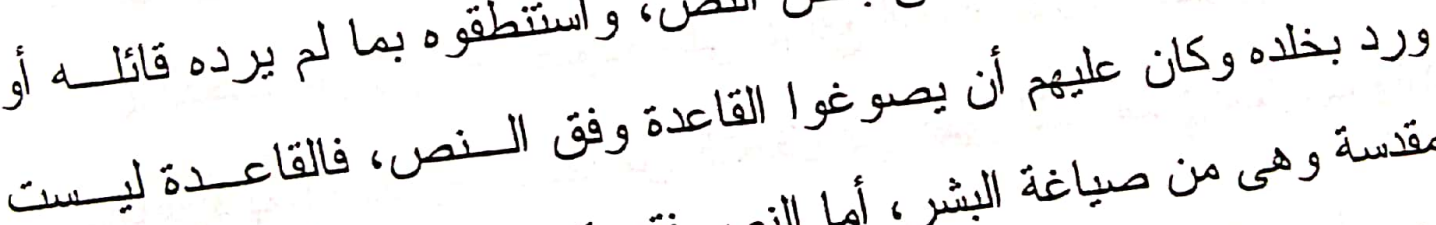

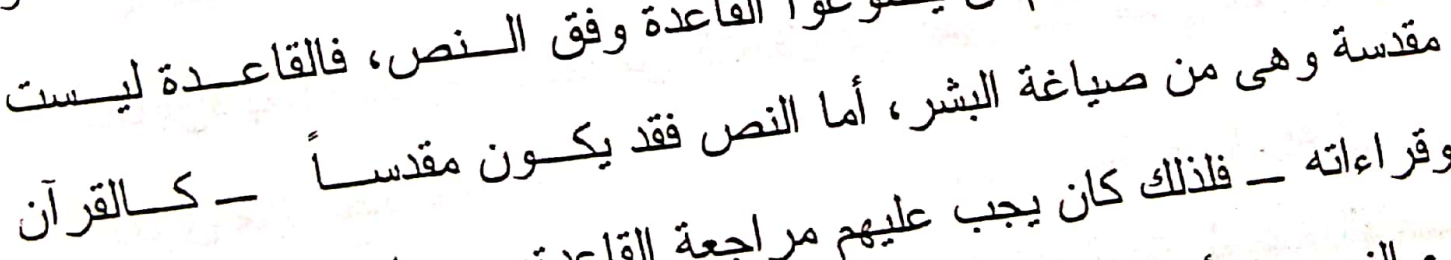

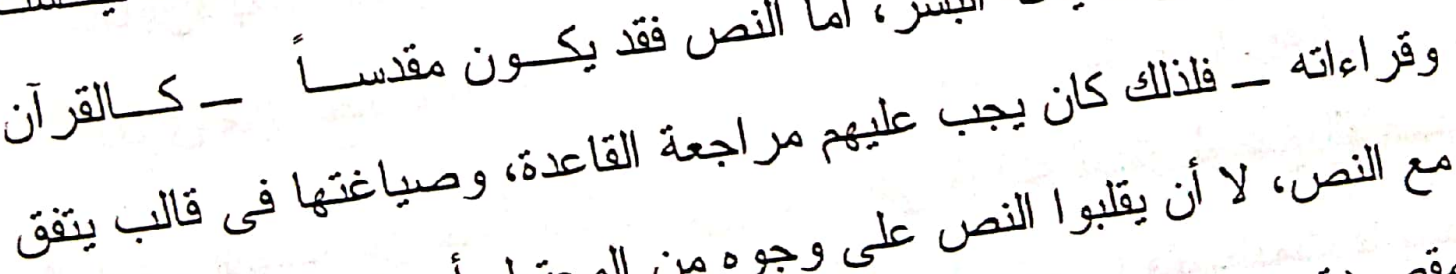

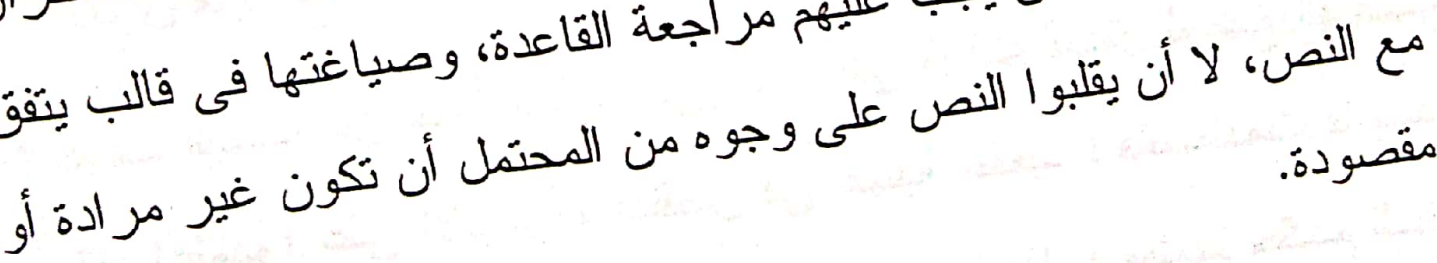




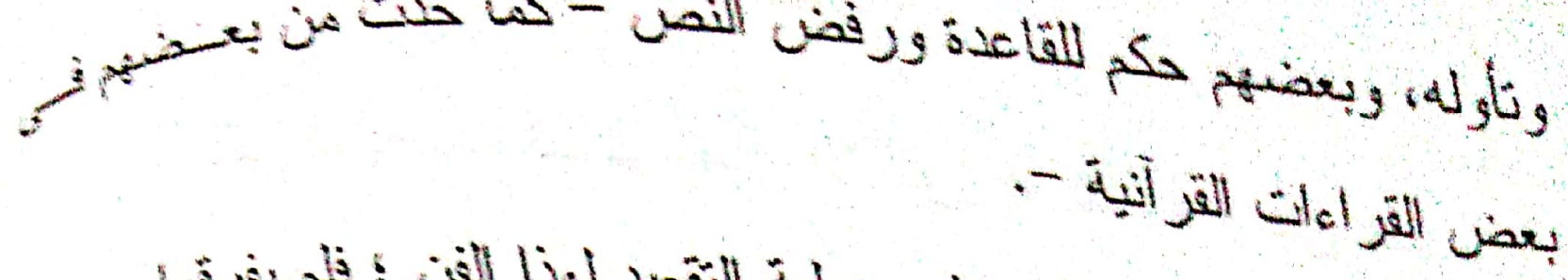

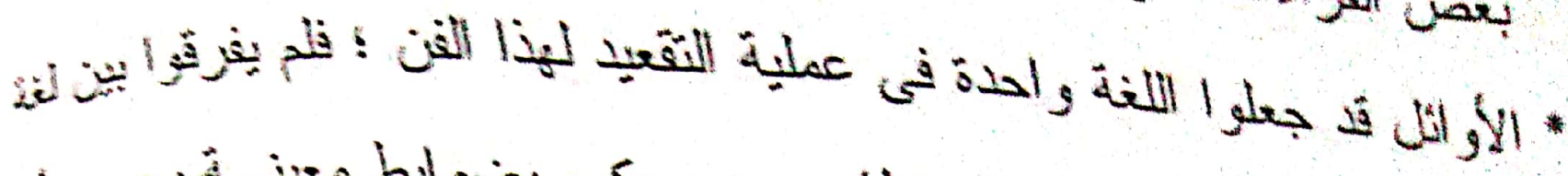

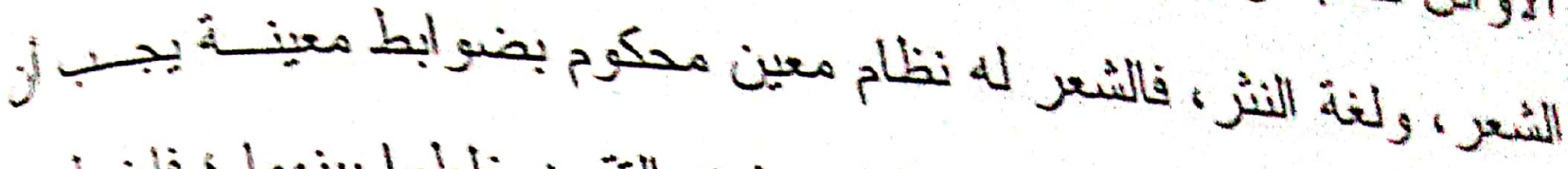

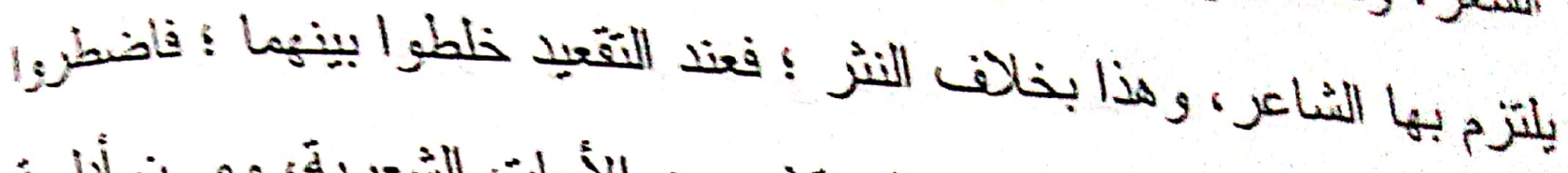

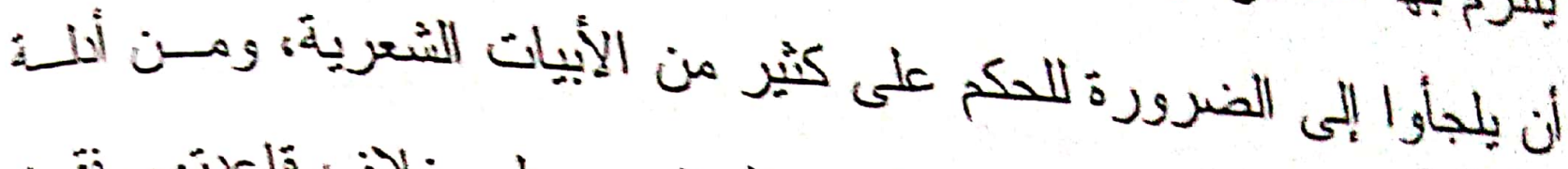

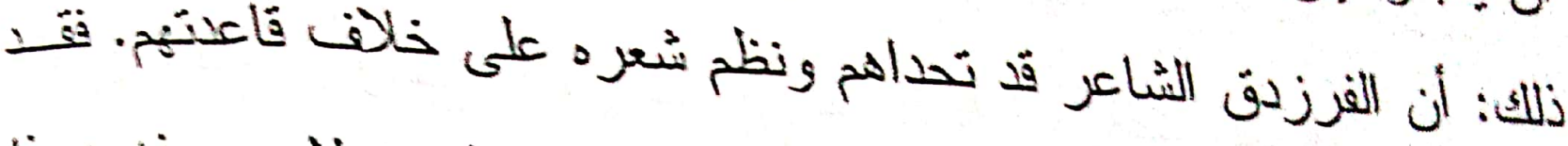

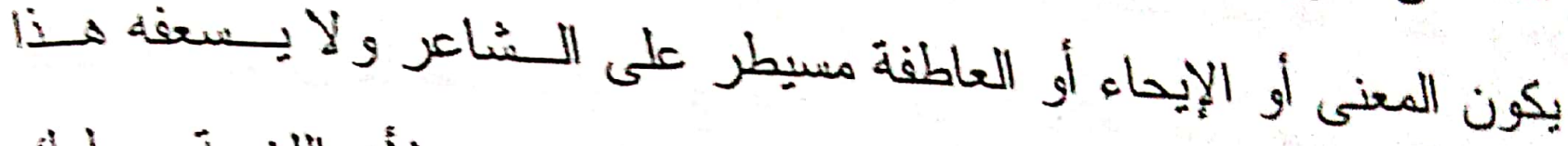

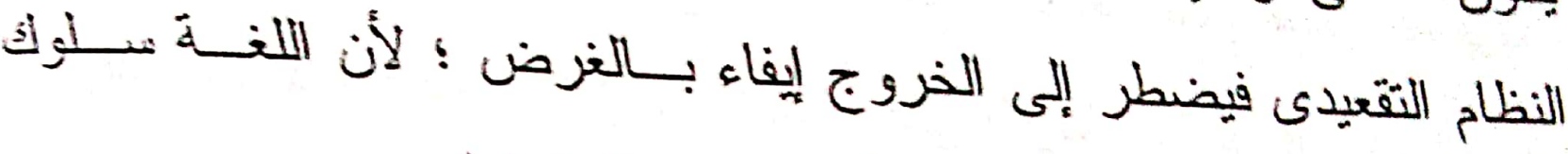
لمتكلم، وليست القاعدة إلا فو الب مأخوذة من هذا البلوك. صل البحث إلى أسباب التأويل فى النحو العربى، وأرجع السبب إلى قَضايا

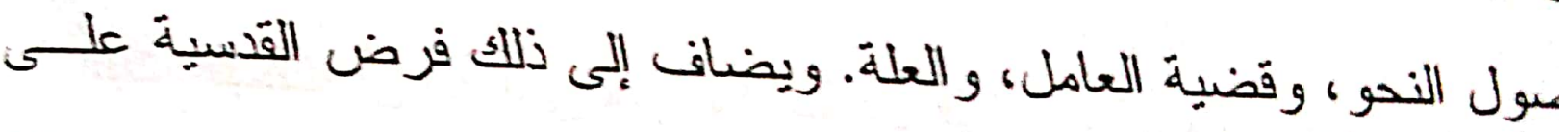

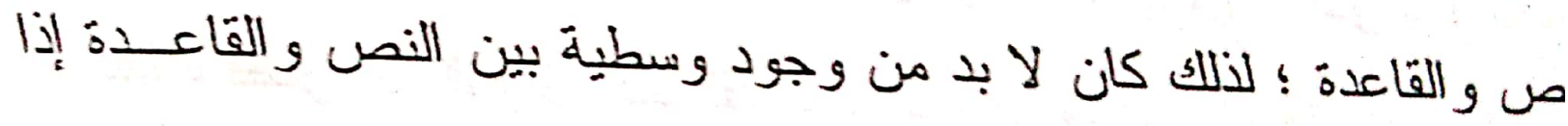
زضا، فلا يطغى أحدهما على الآخر فلم يكن أمامهم إلا تأويل النص دون

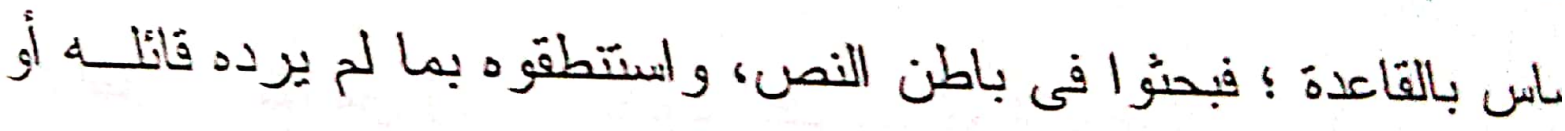

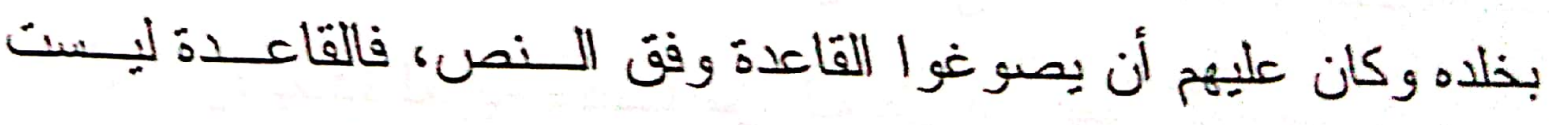

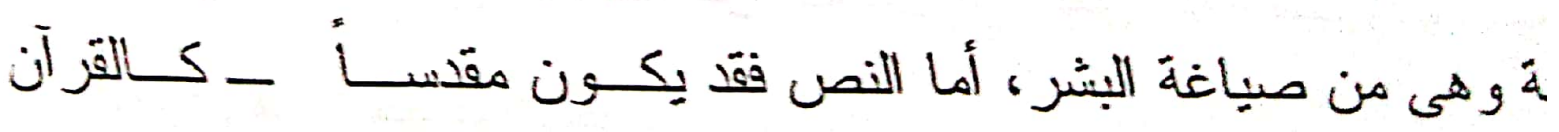

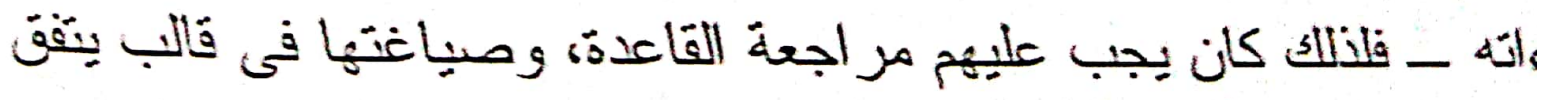
ص، لا أن يقلبوا النص على وجوه من المحتمل أن نكون غير مر ادة أو هرأ 


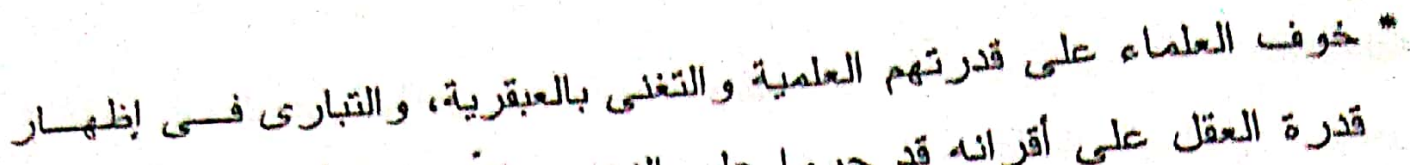

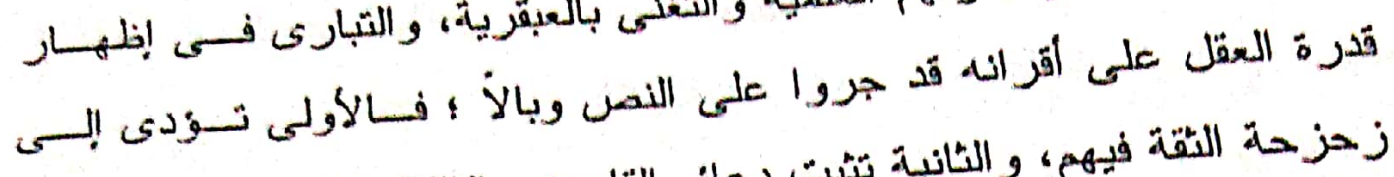

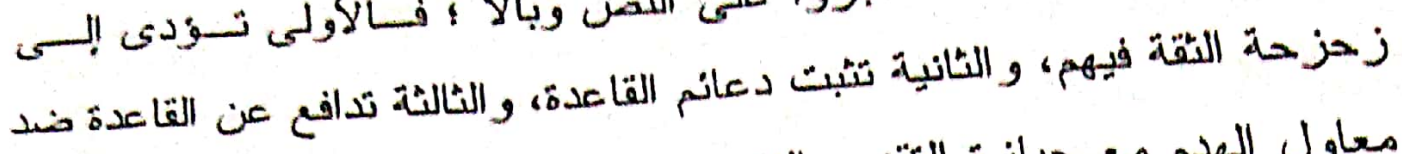

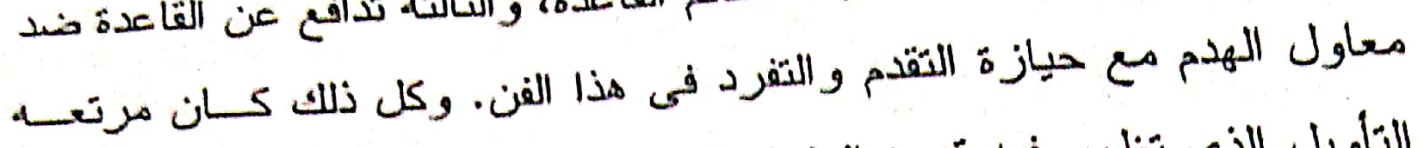

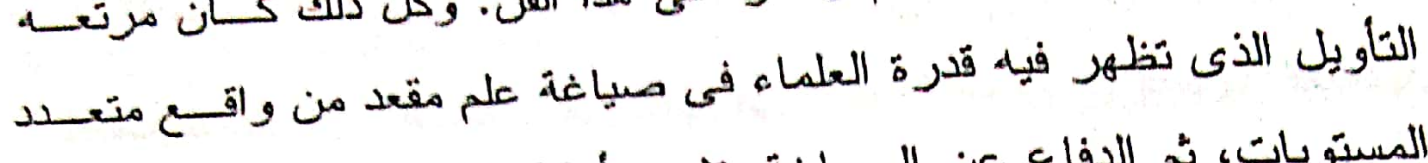

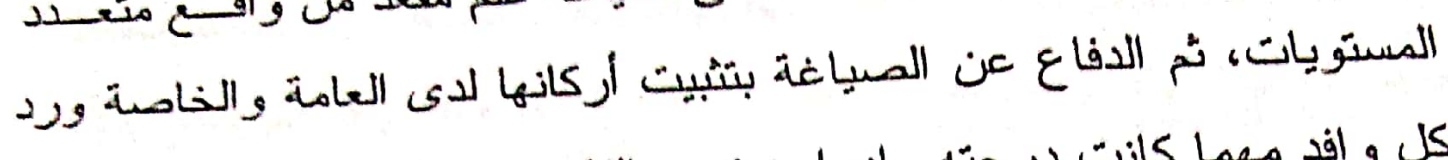
كل و افد مهما كانت درجته و إدر اجه تحث القاعدة بصفة مطردة.

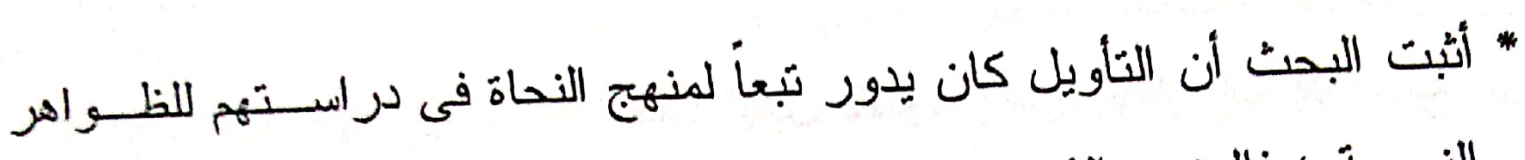

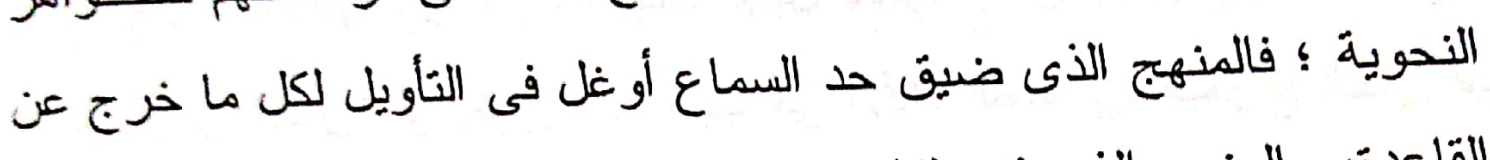

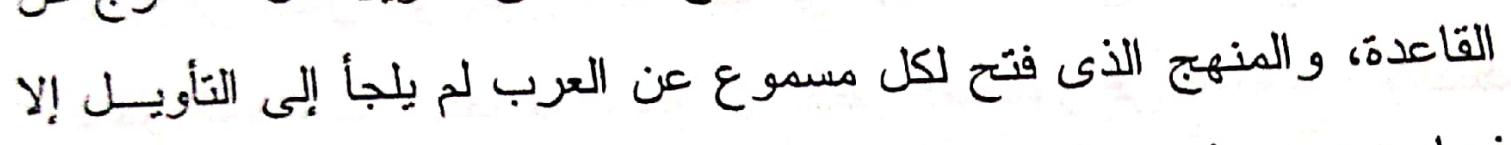
فيما يؤيد به مذهبه وفريقه.

* وظف ابن جنى العقل فى خدمة النص توظيفاً لم يسبق له ؛ فتجده يجمع العلة

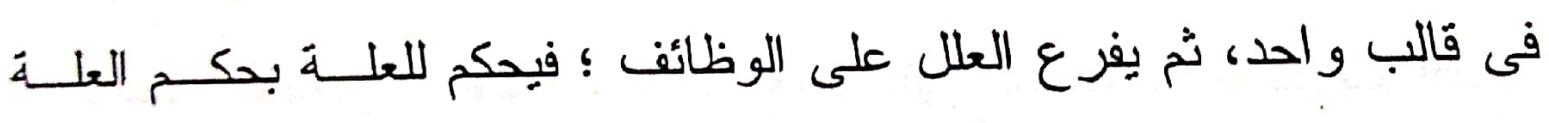
الأخرى، كعلة الشبه - مثلن - فقد توسع فيها فشبه الجملة الاســية لــتلاحم ركنيها بالمفرد، وبالتالى أتبعت حركة الركن الركن الآخر كما تنبع حركـات

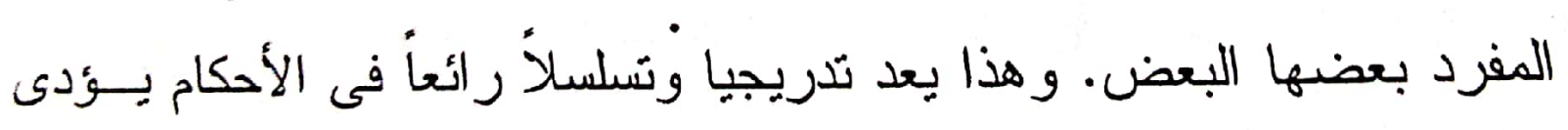
بالقارئ إلى الإقناع، وكذا الأمــر بالنــسبة للحـذف أو الـذكر ، أو التثنيـة و الجمع........ إلخ فتجده يقيس الشئ على الشئ بجامع عام ويعلل له تعلـيلًا عقليا، ثم يسحب الحكم على الجزئية المخالفة فى النص. 
* كثيف البحث عن مظاهز او آليات للتأويل غير ما ذكرث، وكانر الإعراب و البناء، والجمع والإفراد........ إلخ وذكر علة لهذا المعنى الذئرئ. فى النص كعلة التجاور، أو كثرة الاستعمال، أو الثقارب الصوتئ.

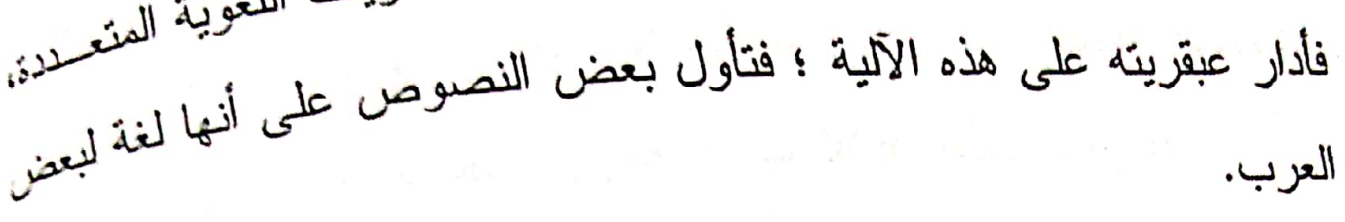
العرب.

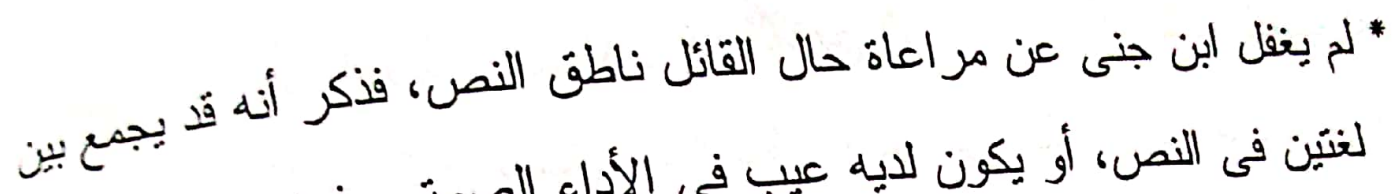

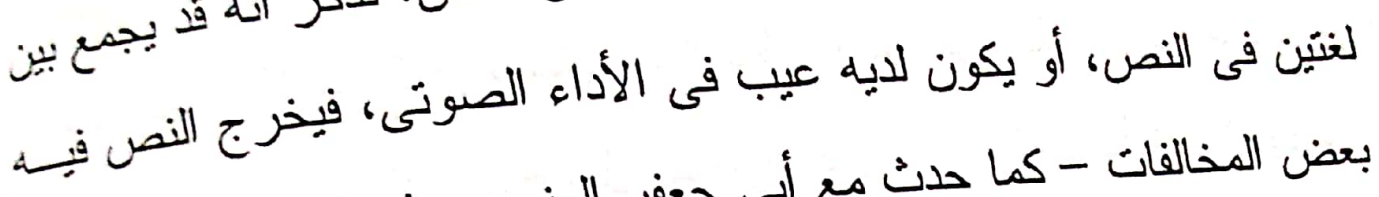

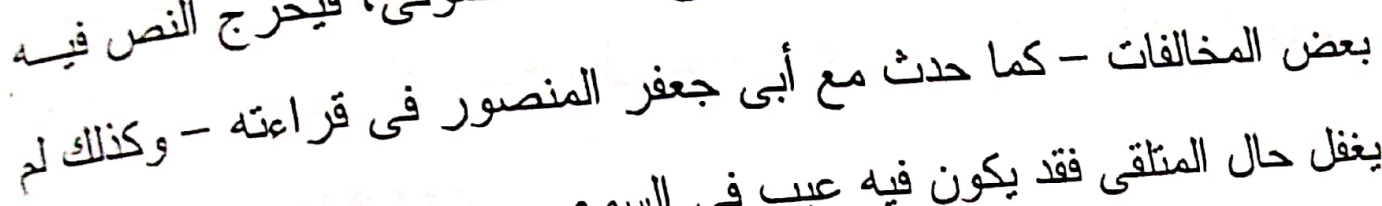
يغفل حال المتلقى فقد بكون فيه عيب في السمع. * من الآليات التى اعتمدها ابن جنى: الاحثمالات الوظيفية المتعددة للكلمة دون

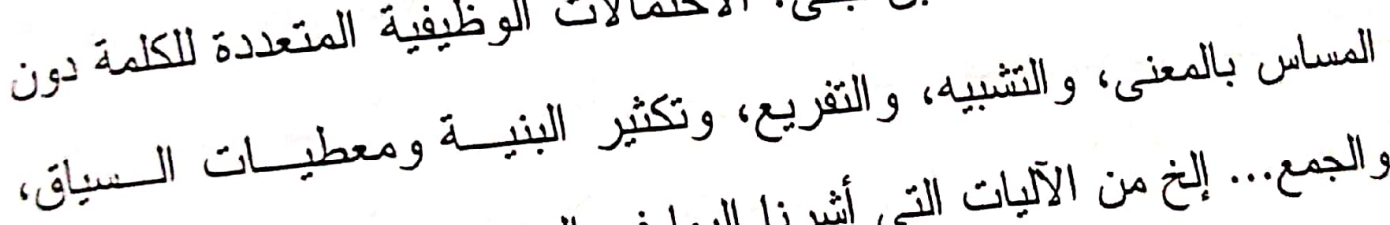

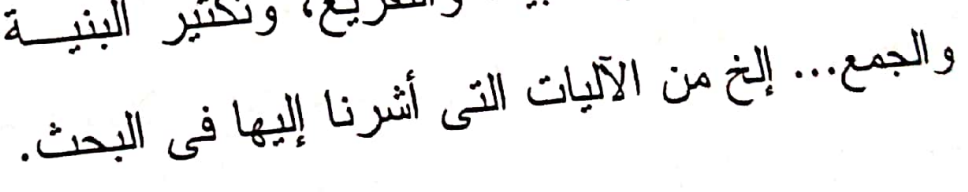


فى نهايه هذا البحث لا أملك إلا أن أشكر اله على ما أفاض به وأجاد،

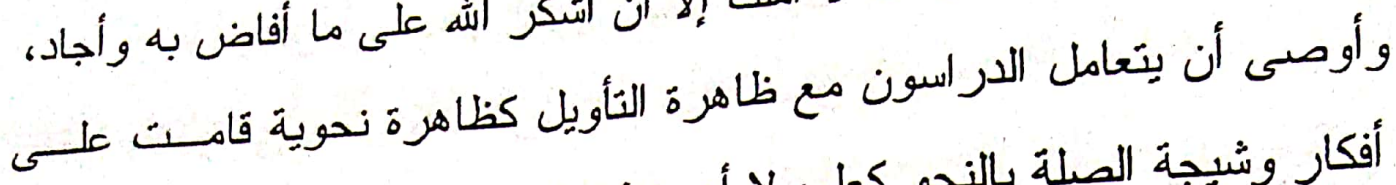

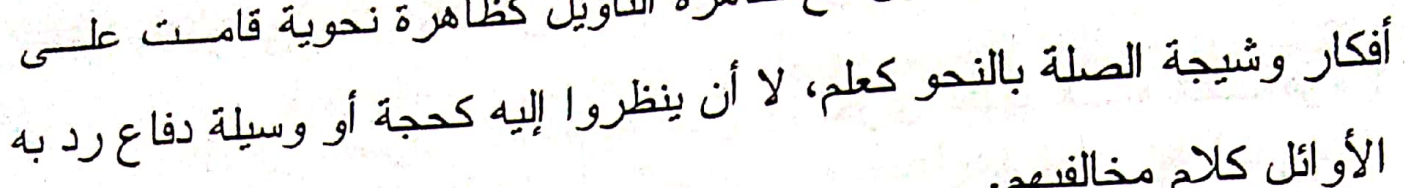
الأو ائل كلام مخالفيهم.

هناك بعض التأويلات التى يجب إغفالها و التى أثقلت كاهل الدراسين،

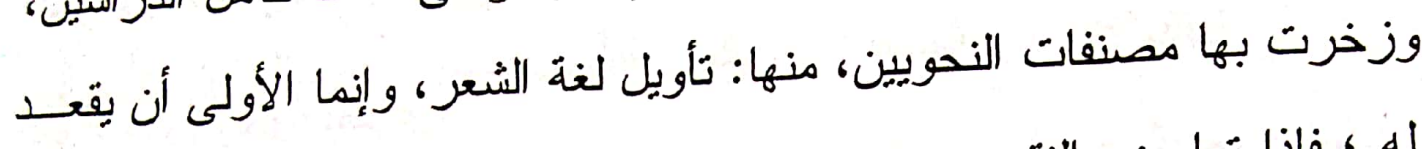

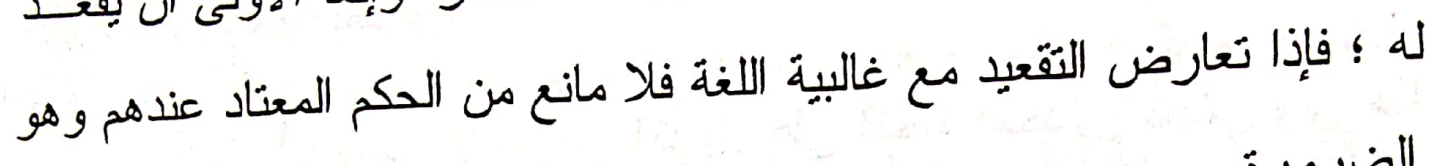

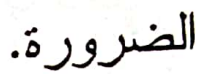

وأيضاً تقبيد الجملة الطلبية بيعض التقييدات وحظرهــا مــن مسـواطن

معينة؛ فالجملة الطلبية جملة ذات معنى ولها حضور لا بنكر كالخبريسـة ؛ فمــا منعوه منها تأولوه إذا وردت فيه، كوقوعها خبرأ ونعتأ، وحالأ... إلخ. وأيضاً تأويل الرأى يجب أن يغفل ؛ لأنه يعبر عن صاحبه صـــوابأ أو خطأ، كتأويل البصريين كلام الكوفيين دون أن يكون مشفوعاً بكلام العـرب شعرا، أو نثرا، أو مثلاً، أو حكمة، أو قولاً عربياً فصيحاً، أو قر اءة.... إلخ. وأيضاً النص المثفرد الذى ندر وروده فلا داعى من تأويله، ويحال إلى المحفوظات ؛ فيجب حفظه و عدم العمل به، أو القياس عليه فلا داعى من إرهاق الكاهل بقول مجهول مفرد، وتأويله وتأليف المجلدات حوله. 


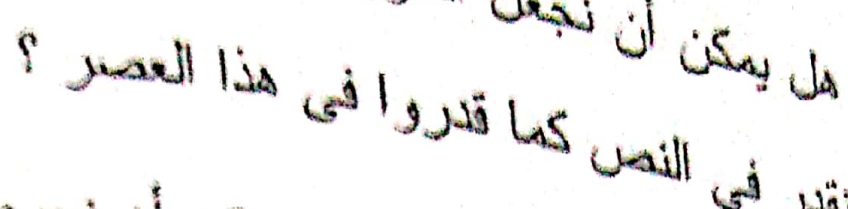

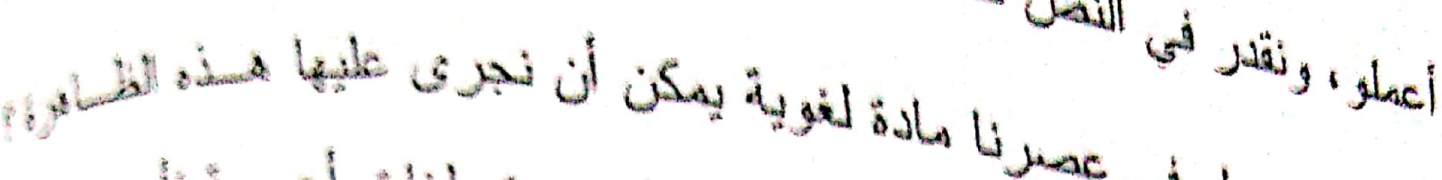

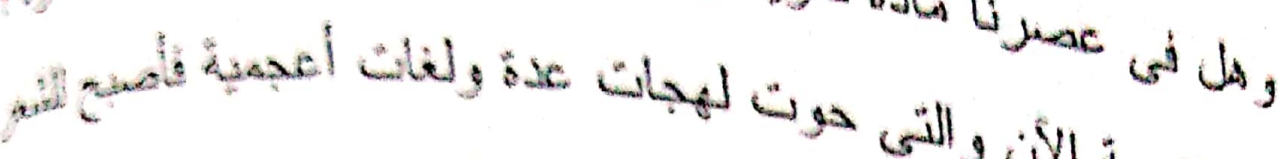

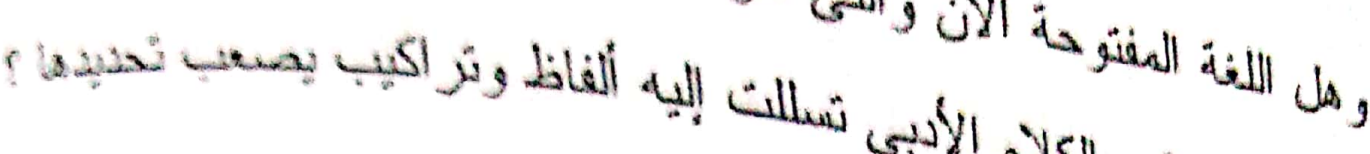

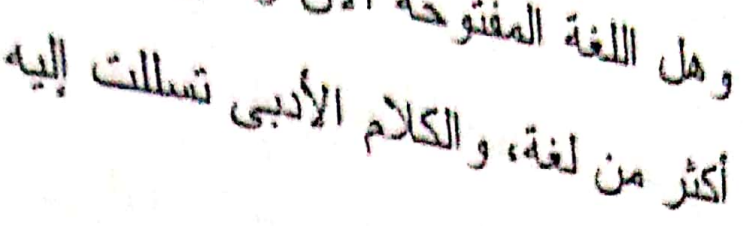
الجواب من وجهة نظلى لكي:

اعتقد أنه يجب ألا يفرض التأويل على النحاة المحدئن كئسن

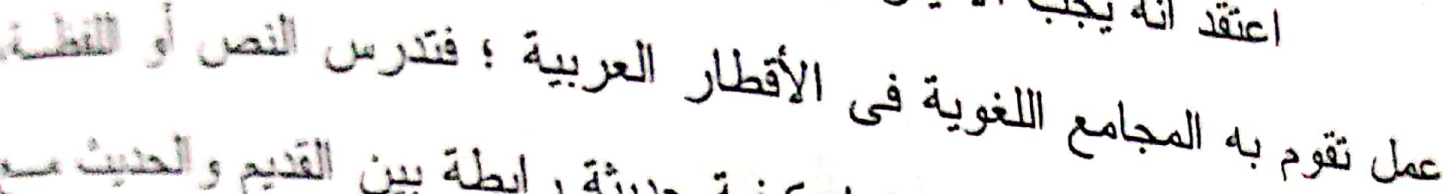

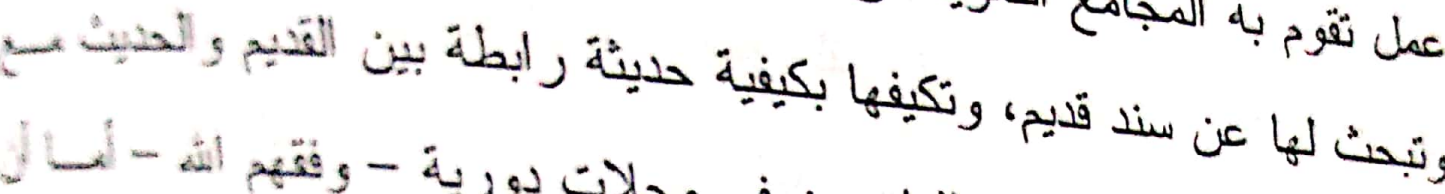

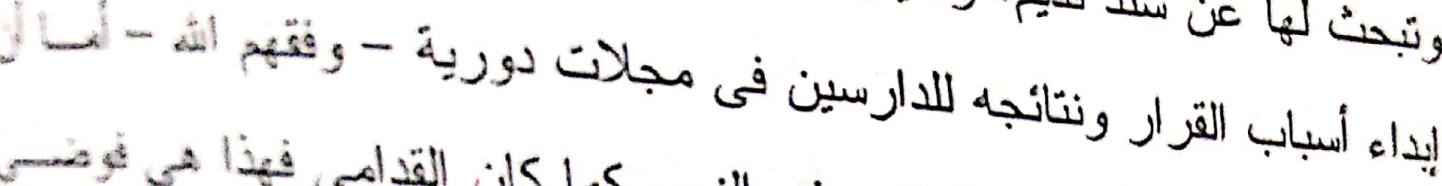

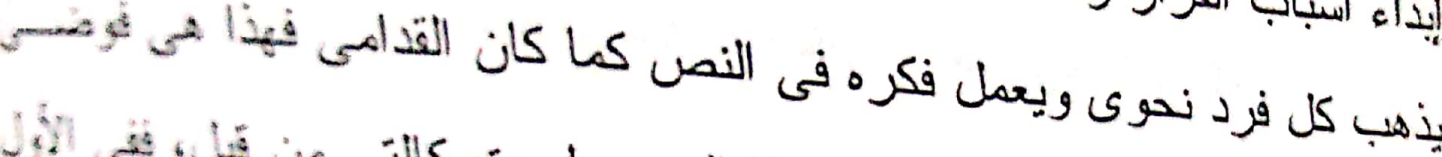

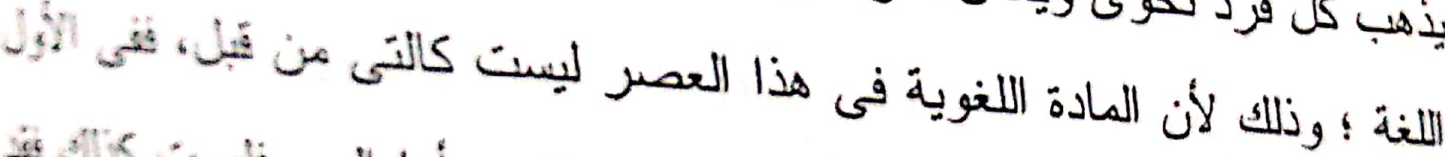

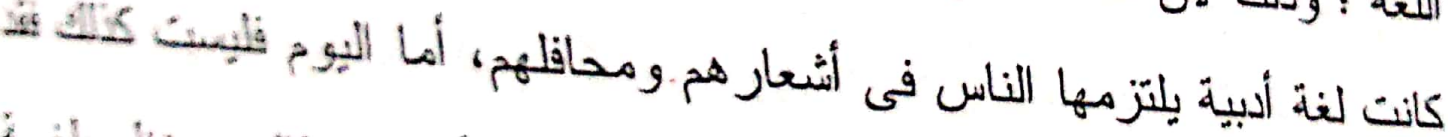

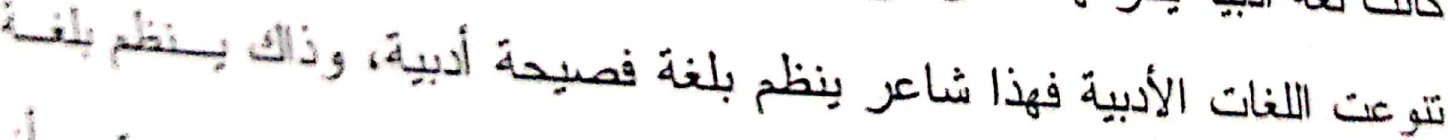

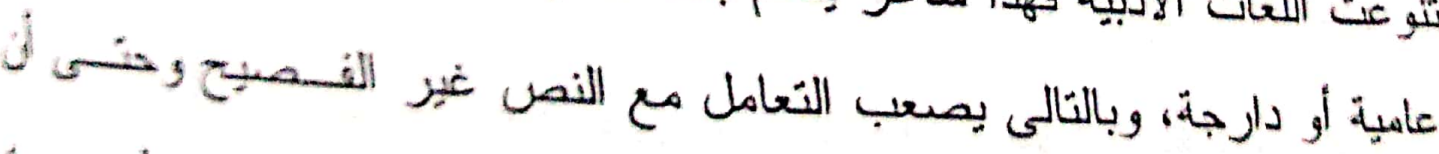

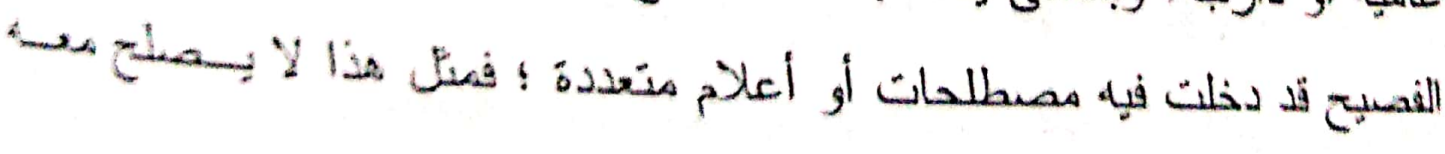
الفزد، و إنما تصلح معاء المؤسسات اللغوية كالمجامع.

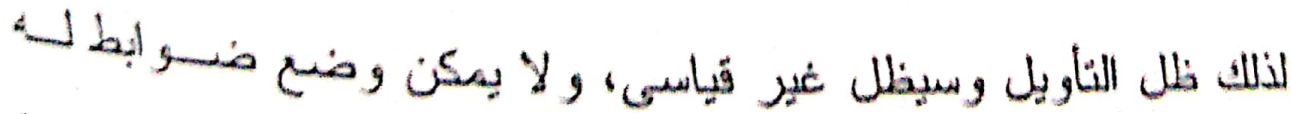

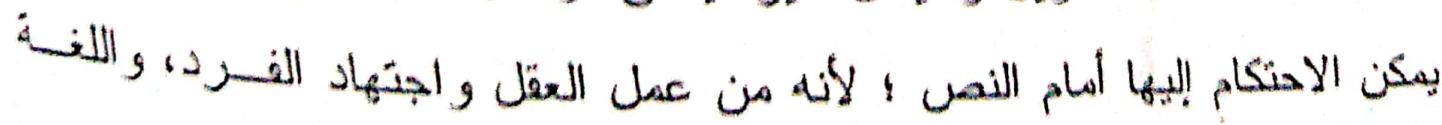




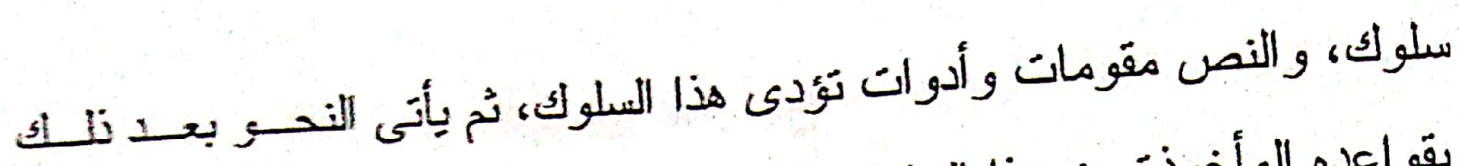
بقو اعده المأخوذة من هذا السلوك.

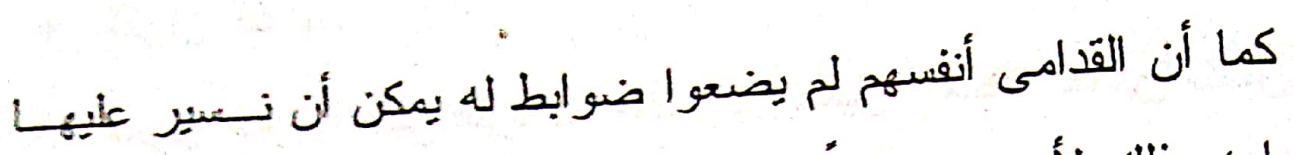

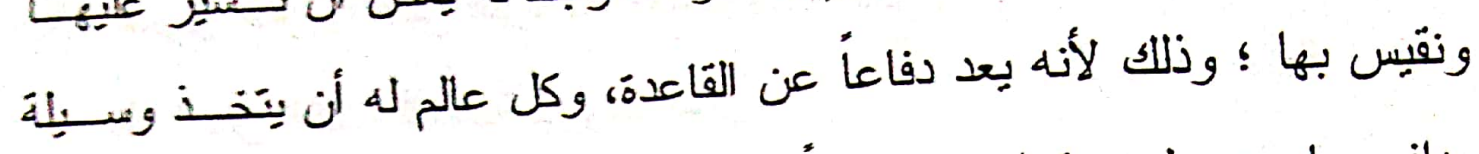

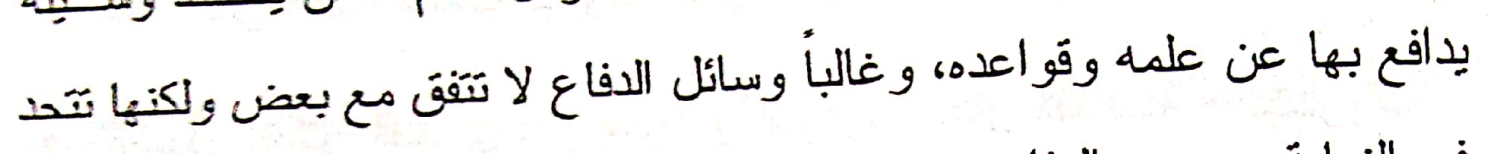

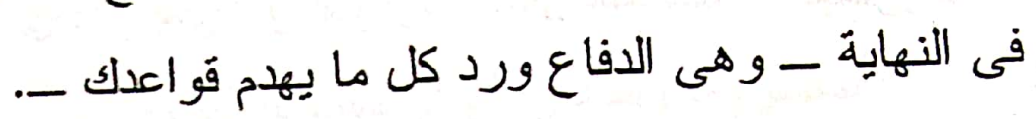

لذلك كان من الصعب أن يكون التأويل قِياسياً بأى حال من الأحوال -

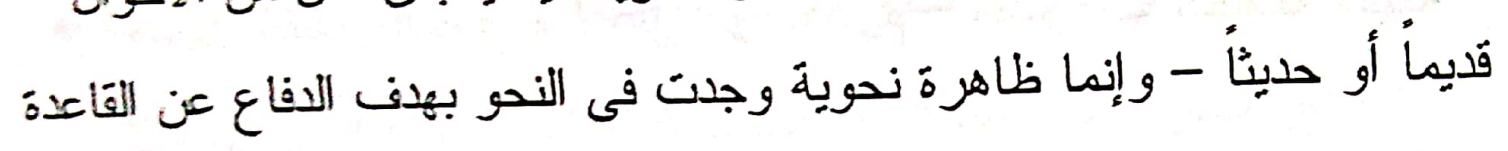
؛ فلا يمكن تجاهلها أو إغفالها ؛ لأنها تعطى انطباعاً عن جهود النحاة وفكرهم.

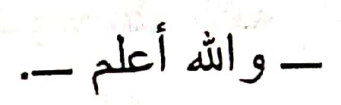

وفى النهاية لا بد أن أضع قلمي، وأرفع بدي إلى واهب الفضل والمنة عساه ألا بردها، و أسأله قطرة من بحر كرمه وينبو عاً من فيض وجوده، وأطلب منه الرضا و غفران الخطأ ومحو الذنوب والآتام، كما أنسأله أن نيكون هذا المقل

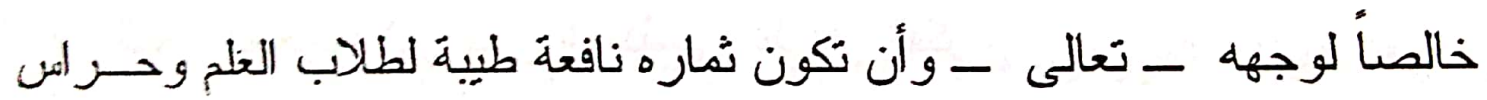
العربية فى كل زمان ومكان. كما أتوجه للقارئ العزيز بالدعاء وستر ما به من زلله، وإصلاح ما بـ هن خلل وقع ؛ وأن بدعو لكاتبه بالخير و الصلاح.

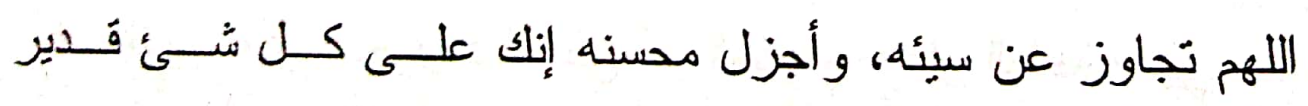
وبالإجابة جدير. وآخر دعو اهم أن الحمد الله رب العالمين 


\section{فهاس المباجي}

أصبول النكير النحوي د / على أبو المكارم - منشّر ات الجامعلة اللبية.

الصول النحو العزبي في نظز النحاة ورأي ابن مضاء وضوء علم اللغن

الآنز آ فى علم أصول النحو للسيوطى، تحقيق / محمد حسن إبماعبل اللثافعى - دلا الكتب العلمية بيزوت لبنان.

البحز المحبط لأبى حيان الأندلى، ط دار الفكر.

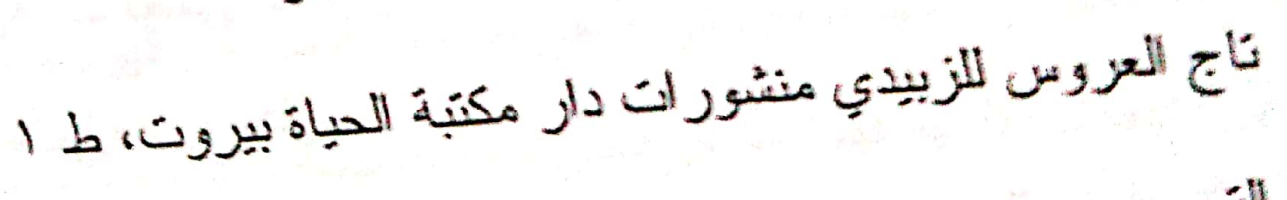

النصريح بمضمون النوضيخ اللنيخخ خالد الأزهرى، ط دار الفكر بدون

سنة. 
تهذيب اللغنة للكز هري تحقيق / إير اهيم الأبياري دار الكاتسب العربسي .01978

خزانة الأدب لعبد القادر البغدادى، تحقيق / عبد السلام هـارون - دار

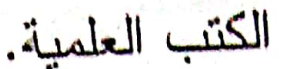

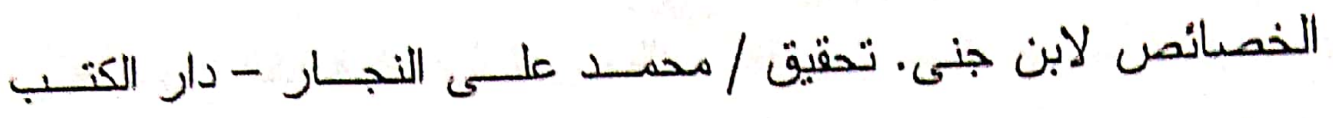
الهصرية، وط دار الهدى للطباعة بيروت لبنان.

دراسات في نظرية النحو العربي وتطبيقاتها. د / صاحب أبو جناح - دار

$$
\text { دار الفكر - طا سنة 1) (هـ _ } 1991 \text { ام. }
$$

دراســة النحو العربي في ضــوء المنـــــه الوصـفي د / خالد

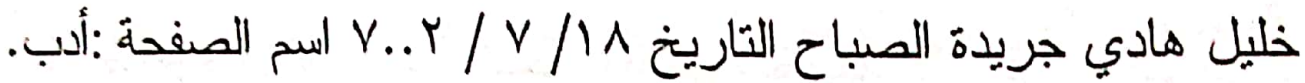
ديوان الأخطل تحقيق / انطون صالحانى، بيروت. ديوان عمرو بن قميئة تحقيق/شارل ليال. كمبردج 1919 • ل ديوان الفرزدق، نشر الصاوى، ونسخة دار صادر. ه ديوان الهذليين ط دار الكتب المصرية. هر صناعة الإعراب لابن جنى تحقيق د / حسن هنداوى ط دار القلم. شرح الأشمونى على ألفية ابن مالك ط الحلبى. شرح التسهيل لابن ماللك تحقيق / محمد بدوى، وعبد الرحمن السيد دار 
ظاهرة الإعراب في النحو العربي ونطبيقها في القر آن الكربم = / أحد سليمان ياقوت. عمادة شئون المكتبات - جامعة الرياض.

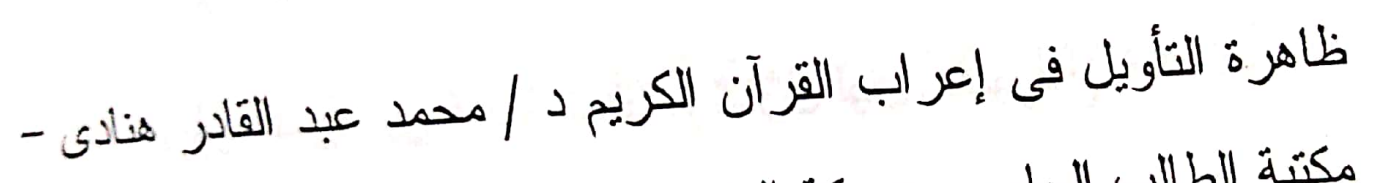

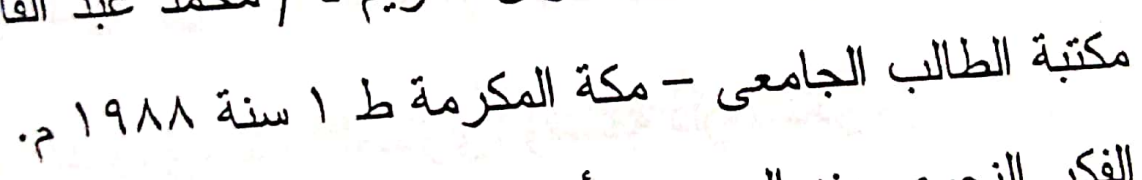

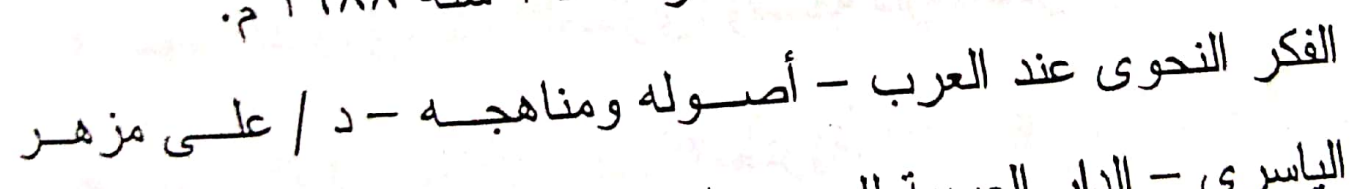

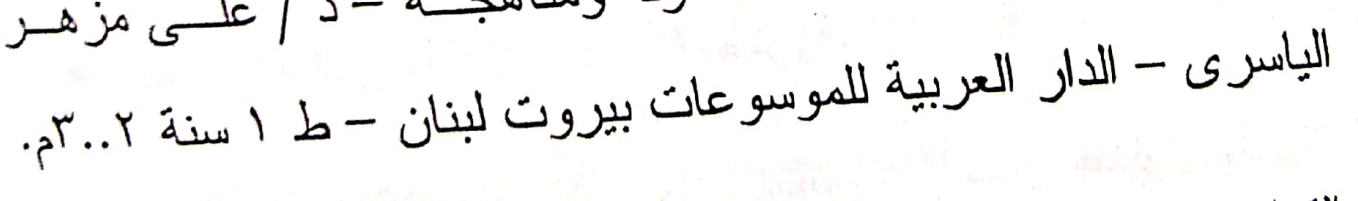

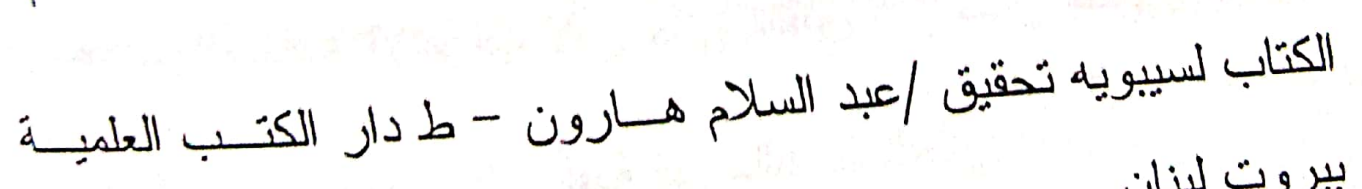
بيروت لبنان.

• الكشاف للزمخشرى ط دار الفكر. لسان العرب لابن منظور المصري دار صادر بيروت 1907. 


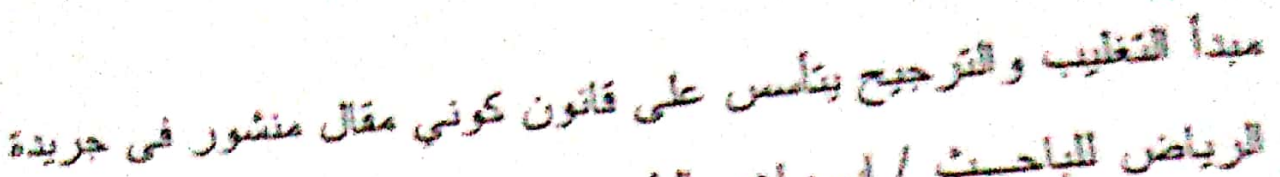

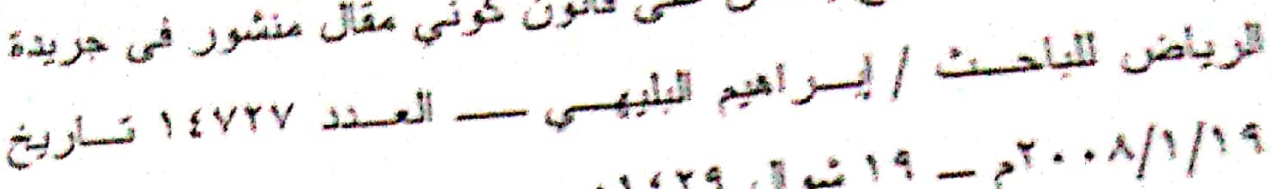

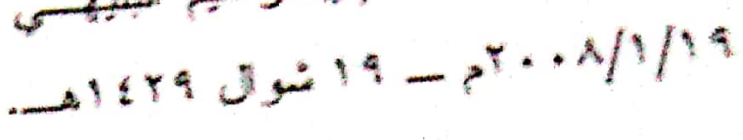

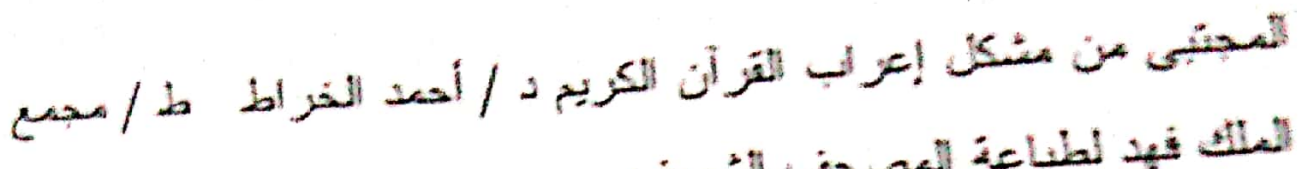

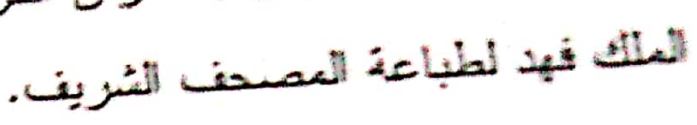

المحتسب لاين جنى تحقيق /على النجدى ناصف، ط المجلس الأعلى

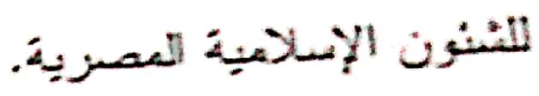

• لمغنى لابن هشام تحقيق/ محد محى الدين ط محمد على صبيح. المقتضنب للمبزد تحقين /هحمد عبد الخالق عضيمة. عالم الكتب بيزوت.

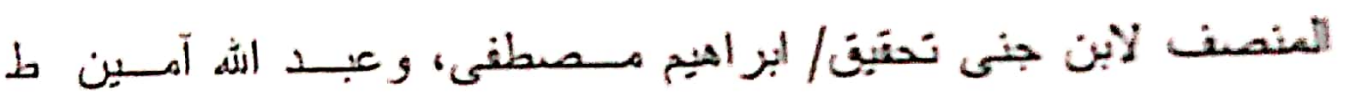
الحنبى. اللنحو الموالقى - عباس حسن، ط دار المعارن المصرية. 